LEANDRO DE ALMEIDA

ESTUDO COMPARATIVO DA ESTAMPABILIDADE DO LATÃO UNS C22000 PRODUZIDO INICIALMENTE PELO PROCESSO DE FUNDIÇÃO CONTÍNUA EM COMPARAÇÃO A FUNDIÇÃO SEMICONTÍNUA 
LEANDRO DE ALMEIDA

ESTUDO COMPARATIVO DA ESTAMPABILIDADE DO LATÃO UNS C22000 PRODUZIDO INICIALMENTE PELO PROCESSO DE FUNDIÇÃO CONTÍNUA EM COMPARAÇÃO A FUNDIÇÃO SEMICONTÍNUA

Dissertação apresentada à Escola Politécnica da Universidade de São Paulo para obtenção do título de Mestre em Ciências.

São Paulo 


\section{ESTUDO COMPARATIVO DA ESTAMPABILIDADE DO LATÃO UNS C22000 PRODUZIDO INICIALMENTE PELO PROCESSO DE FUNDIÇÃO CONTÍNUA EM COMPARAÇÃO A FUNDIÇÃO SEMICONTÍNUA}

Dissertação apresentado à Escola Politécnica da Universidade de São Paulo para título de Mestre em Ciências.

Área de concentração:

Engenharia Metalúrgica e de Materiais

Orientador:

Prof. Dr. Cláudio Geraldo Schön 
Este exemplar foi revisado e corrigido em relação à versão original, sob responsabilidade única do autor e com a anuência de seu orientador.

São Paulo, de de

Assinatura do autor:

Assinatura do orientador:

\section{Catalogação-na-publicação}

Almeida, Leandro

Estudo comparativo da estampabilidade do latão liga UNS C22000 produzidas inicialmente pelo processo de fundição contínua em comparação a fundição semicontínua / L. Almeida - versão corr. -- São Paulo, 2017. $158 \mathrm{p}$.

Dissertação (Mestrado) - Escola Politécnica da Universidade de São Paulo. Departamento de Engenharia Metalúrgica e de Materiais.

1.cobre 2.estampabilidade 3.fundição contínua 4.fundição semicontínua 5.CLC I.Universidade de São Paulo. Escola Politécnica.

Departamento de Engenharia Metalúrgica e de Materiais II.t. 


\section{AGRADECIMENTOS}

Agradeço a todas as pessoas que ajudaram direta e indiretamente para a concretização deste trabalho em especial:

Ao orientador Prof. Dr. Claudio Geraldo Schön, pela amizade, confiança, pelas orientações, discussões e realização desta obra.

Ao Prof. Dr. Nelson Batista Lima do IPEN pelas análises e ensinamentos sobre textura dos materiais utilizados nesta pesquisa.

Ao Prof. Dr. Marcos Domingos Xavier, por participar da minha banca de qualificação e defesa, e pelas orientações ao longo da elaboração deste trabalho e ao Prof. Dr. Ronald Lesley Plaut, por participar da minha banca de qualificação.

Ao Prof. Dr. Marcio Gustavo Di Vernieri Cuppari por participar da minha banca de defesa.

À Paranapanema S.A. e a todos os seus colaboradores que ajudaram de alguma forma para que esse trabalho fosse concretizado. Aos engenheiros colegas de equipe, em especial, Paulo Aniceto, Gustavo Tressia de Andrade, Milton Aranha, Renan Lana, Rodrigo Sanches e Victor Caso Moreira, pelos bate-papos e incentivo a realização não somente deste trabalho, mais também de muitos que estão por vir.

Aos colegas de empresa Ivan Mercado, Júlio Gomes Leite, José Francisco Caetano, Danilson Ferreira de Melo, Gregório Teixeira do Nascimento Junior, Anderson da Silva Carpanezi, Flavio Rodrigues Amorin, Edgar Calderare e Cleison José Raimundo.

À minha esposa Renata Barrant pelo incentivo e paciência nos momentos difíceis e ao meu filho Benicio Barrant Almeida, aos meus familiares que sempre estiveram ao meu lado, em especial meu pai Dorival de Almeida e a minha mãe Maria Zélia da Silveira Almeida que sempre me incentivaram na busca do conhecimento e meu irmão Rodrigo de Almeida e família.

Ao meu sogro Paulo Sergio Barrant e à minha sogra Rosalina Barrant pelas ajudas, incentivos e ensinamentos.

Aos amigos Dilson Fernandes, Flávio Nascimento, Eduardo Martini e Vinicius Ribeiro. 
"A mente que se abre a uma nova ideia jamais voltará ao seu tamanho original." Albert Einstein 


\section{RESUMO}

As curvas limite de conformação (CLC) são utilizadas há mais de 50 anos. Propostas inicialmente para o desenvolvimento de produtos provenientes da indústria automobilista em função das necessidades apresentadas pela área, são atualmente aplicadas de maneira geral para a indústria da estampagem na produção de inúmeros tipos de peças, oferecendo previsões de possíveis falhas e/ou defeitos durante as etapas do processo de estampagem. As CLC's permitem prever o afinamento excessivo, enrugamento, estiramento e é claro, a fratura da peça. As diferenças metalúrgicas existentes entre os dois processos iniciais - fundição contínua (F.C.) e fundição semicontínua (F.S.C.) - resultam em diferenças nas propriedades finais obtidas para uma mesma rota de laminação a frio e recozimentos intermediários do material especificado. Desta forma, torna-se indispensável um estudo sobre a influência dos processos de fabricação iniciais F.C. e F.S.C. com relação à estampabilidade da liga, sendo esta avaliação efetuada através das CLC's obtidas por ensaios de tração uniaxiais, propostos pelo IRSID ("Institut de Recherches de La Sidérurgie"), (lado esquerdo da curva $\varepsilon_{2}<0$ ) e ensaio Erichsen (lado direito da curva $\varepsilon_{2}>0$ ) e do ensaio de Nakazima reduzido em $60 \%$, ou seja, todo o ferramental e os corpos de prova utilizados nos ensaios foram reduzidos em $60 \%$ das dimensões mencionadas pela norma ISSO 12004-2. A diferença microestrutural apresentada entre as etapas de fabricação dos dois processos avaliada através de ensaios de determinação do tamanho de grão, limites de resistência à tração, escoamento $(0,2 \%)$, alongamento (em 50,80 mm), coeficientes de encruamento $n$, resistência $K$, ensaios de "orelha", levantamento da $\mathrm{CLC}_{0}$, Erichsen e textura, auxiliaram nas conclusões finais do levantamento das CLC's para os dois processos do material acabado e metodologias. O processo de fundição semicontínua nas condições processadas apresentou melhores combinações entre as propriedades, exceto na formação de "orelha" apresentada na etapa intermediaria de processamento do material. Principalmente o parâmetro $\mathrm{CLC}_{0}$ no plano da chapa, resultou em uma deformação $\varepsilon_{1} 19 \%\left(\varepsilon_{2}=0\right)$, superior à apresentada pelo processo F.C., deformação muito importante para a fabricação de peças estampadas. Evidenciou-se também uma diferença de aproximadamente 37\% entre as metodologias IRSID x Nakazima reduzido na obtenção da deformação 
plana para o processo F.C. e $31 \%$ para o processo de F.S.C.. Nas condições de deformação; estiramento biaxial, tração uniaxial e embutimento profundo, a chapa produzida pelo processo de fundição contínua apresenta melhor desempenho.

Palavras-chave: cobre; estampabilidade; fundição contínua; fundição semicontínua; CLC; 


\section{ABSTRACT}

Forming limits curves (FLC) are used for more than 50 years. Initially proposed for the development of products from the automobile industry in terms of the needs of the area. It is currently being applied in general to the metal forming industry in the production of numerous types of parts, providing predictions of possible faults and / or defects during the stages of the stamping process. The FLC's can predict excessive thinning, wrinkling, stretching and of course, the fracture of the part. The existing metallurgical differences between the two initial processes - continuous casting (C.C.) and semi-continuous casting (S.C.C.) - result in differences in the final properties obtained for the same route of cold rolling and intermediate annealing of the specified material. Thus, it is essential to study the influence of the initial manufacturing processes $\mathrm{CC}$ and SCC with respect to the formability of the sheets. This investigation is based on the, assessment of the FLC's obtained by uniaxial tensile tests proposed by IRSID ("Institut de Recherches de Sidérurgie"), $\left(\varepsilon_{2}<0\right.$, left side of the curve) and Erichsen test (right side of curve. $\varepsilon_{2}>0$ ) and the Nakazima test reduced by $60 \%$. The difference between the sheets obtained in both processing routes was evaluated by the following parameters: grain size, tensile strength limits, yield strength $(0.2 \%)$, elongation (at $50.80 \mathrm{~mm}$ ), strain hardening coefficient $n$, resistance $\mathrm{K}$, "earing" test, lifting of the $\mathrm{CLC}_{0}$, Erichsen test and texture where discussed in view of the obtained FLC's for both the two processes of the finished material. The semi-continuous casting process in processed conditions showed better combinations of properties except the formation of "earing" presented at the intermediate stage of processing of the material. Particularly the evaluation of the FLC 0 parameter resulted in a strain in the plate plane $\varepsilon_{1} 19 \%\left(\varepsilon_{2}=0\right)$ superior to the sheet obtained by the continuous casting process. A difference of approximately $37 \%$ between the IRSID x Nakazima methodologies was also reduced in obtaining the flat deformation for the F.C. process and $31 \%$ for the F.S.C. process. However, for other deformation paths; biaxial stretching, uniaxial traction and deep drawing of the results for the continuous casting sheet were superior.

Keywords: copper; drawing; continuous casting; semi- continuous casting; FLC; 


\section{LISTA DE ILUSTRAÇÔES}

Figura 1 Variação da densidade de orientação de várias orientações ideias com relação à \% de redução na laminação (adaptado de Kallend e Davies (1971)). 29

Figura 2 Efeito do tempo de recozimento a $400^{\circ} \mathrm{C}$ na dureza do latão $95 \%$ Cu e $5 \%$ Zn com 60\% de redução de área. (adaptado de Davis (2001)).

Figura 3 Efeito da temperatura de recozimento e \% redução na formação de "orelha" no latão (adaptado de Stüme e Faustmann (1969)).

Figura 4 Esquema de seção típica do processo de estampagem (adaptado de HOSFORD e DUNCAN, 1999).

Figura 5 Efeito do tamanho de grão versus limite de resistência à tração de várias ligas de latão recozidas (adaptado de DAVIS, 2001). .35

Figura 6 Comparação das curvas de tensão-deformação convencional e tensãodeformação verdadeira e curva tensão-deformação na base log. 37

Figura 7 Esquema do ensaio Erichsen (adaptado de GRAVUS et al., 2010). 39

Figura 8 Índice Erichsen x tamanho de grão e espessura para o latão 70:30 40

Figura 9 Esquema de ensaio de "orelha" (adaptado da ISSO 11531, 2015). 40

Figura 10 Curva limite de conformação, descoberta. (adaptado de EMMENS, 2011)

Figura 11 Diagrama representativo das deformações principais expostas na curva limite de conformação (adaptado de KEELER, 1994).

Figura 12 Peça estampada e seus possíveis caminhos de deformação identificados nas curvas limites de conformação (adaptado de HOSFORD e DUNCAN, 1999).

Figura 13 Curva limite de conformação demonstrando o local de possíveis ocorrências (adaptado de HOLMBERG; ENQUIST; THILDERKVIST, 2003).

Figura 14 Corpos de prova utilizados para o levantamento da curva limite de conformação de acordo com o método proposto pelo IRSID (adaptado de Schwindt et al (2015)).

Figura 15 Comparação da curva limite de conformação obtida pelo ensaio de Marciniak e Nakazima (adaptado de TATA Steel, 2013) 48 
Figura 16 Comparativo da curva limite de conformação obtida pelo método IRSID $x$ Nakazima e tração com corpo de prova de largo (USIMINAS, 1999). 49

Figura 17 Formato de medição do diâmetro dos círculos antes e após os ensaios (adaptado: ASTM E 2218). .50

Figura 18 Demonstração da influência do diâmetro dos círculos na obtenção da curva limite de conformação (IRSID, 1975). .52

Figura 19 CLC's obtidas com lubrificantes diferentes (adaptado de FOLLE et al, 2008). .53

Figura 20 Curva limite de conformação do cobre UNS C11000, demonstração do aumento de $\mathrm{n}$ e da curva limite de conformação, evidenciando que quanto maior o valor de $n$ maior é a estampabilidade da liga (MELANDER, 1982). 55

Figura 21 Curva limite de conformação, CLC 0 (adaptado de KEELER, 2015). .56

Figura 22 Corpo de prova para obtenção da deformação planar e variações dimensionais de $\mathrm{A}$ a $\mathrm{H}$ para as cotas $\mathrm{A}, \mathrm{B}$ e $\mathrm{C}$ de diferentes corpos de provas (adaptado de WAGONER, 1980).

Figura 23 Corpos de prova para a comparação da deformação planar x coeficiente de encruamento (adaptado de WAGONER, 1981).

Figura 24 Corpo de prova para ensaio de determinação da deformação planar (BJÖRKLUND e NILSSON, 2014). .58

Figura 25 Corpo de prova para ensaio de determinação da deformação planar (adaptado de XAVIER e PLAUT, 2012). .59

Figura 26 Curva limite de conformação da liga C26000 obtida através do ensaio Marciniak (adaptado de MANDIGO; SHAPIRO, 1984). 60

Figura 27 Curva limite de conformação exposta na norma ASTM E 2218, latão 70:30. (adaptado de ASTM E2218, 2015).

Figura 28 Curva limite de conformação (a) Cobre tough pitch copper (UNS C11000) e (b) Cobre oxygen-free (UNS C10200) (MELANDER, 1982). 62

Figura 29 Curva limite de conformação (a) Latão e (b) Cobre - Níquel (MELANDER, 1982). 62

Figura 30 Curva limite de conformação, para espessura final de 1,30 mm do "clad", com variação da espessura inicial do alumínio e chapa de cobre "puros" (UNS C11000) (adaptado de TSENG; HUNG; HUANG, 2010).

Figura 31 Curva limite de conformação latão 70:30 em diferentes condições (têmperas) (adaptado de DAVIS, 2001). 
Figura 32 Curvas limite de conformação do Tomback UNS C22000 e UNS C23000 (adaptado de DAVIS, 2001).

Figura 33 Curva limite de conformação da liga UNS C23000 obtida pelo ensaio de Marciniak para vários tamanhos de grão, espessura 1,00 mm (adaptado de STACHOWICZ, 1989).

Figura 34 Corpo de prova e curva limite de conformação do aço "macio" (Mild steel) elaborada através dos ensaios de tração (adaptado de HOLMBERG; ENQUIST; THILDERKVIST, 2003).

Figura 35 Fluxograma dos processos iniciais de fundição continua e fundição semicontínua.

Figura 36 Fluxograma do processo de laminação a frio e acabamento para os processos de fundição contínua e fundição semicontínua. 73

Figura 37 Esquema de retirada de amostra para análise macrografica (b) e metalografica (a) de tamanho de grão. .74

Figura 38 Confecção dos corpos de prova, (a) Fresa e gabarito para o fresamento dos corpos de prova e (b) Dimensional dos corpos de prova. .76

Figura 39 Marcação central do corpo de prova para a medição da largura e espessura para obtenção do $\Delta R$ e $r$.

Figura 40 Exemplo de obtenção de $\mathrm{K}$ e $\mathrm{n}$ através da equação de potência obtida no Excel. .78

Figura 41 Determinação dos valores de $n$ e K na curva log-log (SOUZA, 1982). .....79

Figura 42 Corpos de prova cortados na eletroerosão (IRSID -"Institut de Recherches de la Sidérurgie").

Figura 43 Corpo de prova para ensaio Nakazima reduzido. .82

Figura 44 Tela, tinta e catalizador utilizados para a estampagem dos círculos nos corpos de prova. .83

Figura 45 Estampagem dos corpos de prova. .84

Figura 46 Corpos de prova estampados (IRSID -"Institut de Recherches de la Sidérurgie").

Figura 47 Estampagem dos círculos eletroquimicamente. .86

Figura 48 Círculos estampados pelo processo de serigrafia. .86

Figura 49 Forma de medição dos círculos antes (a) e após os ensaios (b). .88

Figura 50 Demonstração da região de medição dos círculos após a realização dos ensaios de tração uniaxial. 
Figura 51 Ferramental utilizado no ensaio Nakazima reduzido (adaptado de SCHWINDT, 2014).

Figura 52 Corpo de prova para medição da deformação planar, metodologia proposta pelo IRSID (adaptado de SCHWINDT, 2014)

Figura 53 Corpo de prova reduzido em 6 vezes do proposto por Wagoner (1981) tipo H com comprimento de $150,00 \mathrm{~mm}$.

Figura 54 (a) Corte das amostras no centro das chapas e (b) remoção das camadas por lixamento e corrosão para análise da textura no centro da espessura do material.

Figura 55 Macrografia da superfície das bobinas fresadas (a) Fundição contínua (F.C.) e (b) Fundição semicontínua (F.S.C.) + Laminação a quente.

Figura 56 Distribuição dos dados de tamanho de grão para os dois processos do material fresado.

Figura 57 Histograma dos dados de tamanho de grão para os dois processos do material fresado. 96

Figura 58 Micrografias (a) Processo de fundição contínua e (b) Processo de fundição semicontínua + Laminação a quente.

Figura 59 Micrografias (a) Processo de fundição contínua encruado e (b) Processo de fundição semicontínua + Laminação a quente encruado. 98

Figura 60 Resultados médios das propriedades físicas do material com espessura $1,83 \mathrm{~mm}$ no estado encruado para os dois processos F.C. e F.S.C 98

Figura 61 Resultados médios de alongamento do material com espessura 1,83 mm no estado encruado para os dois processos F.C. e F.S.C..

Figura 62 Distribuição dos dados de tamanho de grão para os dois processos, materiais intermediários moles. 102

Figura 63 Histograma dos processos de fundição contínua e de fundição semicontínua nos materiais intermediários. 103

Figura 64 Micrografias (a) Processo de fundição contínua e (b) Processo de fundição semicontínua materiais intermediários. 104

Figura 65 Resultados médios das propriedades físicas do material com espessura $1,83 \mathrm{~mm}$ no estado recozido para os dois processos F.C. e F.S.C 104

Figura 66 Resultados médios de alongamento do material com espessura 1,83 mm no estado recozido para os dois processos F.C. e F.S.C. 105 
Figura 67 Resultados médios dos coeficientes de encruamento (n) do material com espessura $1,83 \mathrm{~mm}$ no estado recozido para os dois processos F.C. e F.S.C.. 106

Figura 68 Resultados médios dos coeficientes de resistência $(K)$ do material com espessura $1,83 \mathrm{~mm}$ no estado recozido para os dois processos F.C. e F.S.C.. 107

Figura 69 Resultados médios das propriedades físicas do material com espessura $1,10 \mathrm{~mm}$ no estado encruado para os dois processos F.C. e F.S.C 111

Figura 70 Resultados médios do alongamento do material com espessura $1,10 \mathrm{~mm}$ no estado encruado para os dois processos F.C. e F.S.C..

Figura 71 Micrografias (a) Processo de fundição contínua e (b) Processo de fundição semicontínua materiais acabados encruados.

Figura 72 Distribuição dos dados de tamanho de grão para os dois processos (acabado - mole) 114

Figura 73 Histograma dos processos de fundição contínua e de fundição semicontínua dos materiais acabados. .115

Figura 74 Micrografias (a) Processo de fundição contínua e (b) Processo de fundição semicontínua materiais acabados moles.

Figura 75 Resultados médios das propriedades físicas do material com espessura $1,10 \mathrm{~mm}$ mole, para os dois processos F.C. e F.S.C. 116

Figura 76 Resultados médios do alongamento do material com espessura $1,10 \mathrm{~mm}$ no estado encruado para os dois processos F.C. e F.S.C..

Figura 77 Curva de amolecimento do material acabado com espessura 1,10 mm para os dois processos F.C. e F.S.C. 118

Figura 78 Resultados médios dos coeficientes de encruamento (n) do material com espessura $1,10 \mathrm{~mm}$ acabado no estado recozido para os dois processos F.C. e F.S.C 119

Figura 79 Resultados médios dos coeficientes de resistência $(\mathrm{K})$ do material com espessura $1,10 \mathrm{~mm}$ acabado no estado recozido para os dois processos F.C. e F.S.C.

Figura 80 Curva limite de conformação obtida pelo ensaio de tração uniaxial (IRSID) e ensaio Erichsen do material acabado, processo fundição contínua e fundição semicontínua (identificação de pontos dispersos excessivamente 1 e 2). .123 
Figura 81 Curva limite de conformação obtida pelo ensaio de tração uniaxial (IRSID) e ensaio Erichsen do material acabado, separação de processos e corpos de prova (fundição contínua e fundição semicontínua).

Figura 82 Corpo de prova número 4 do processo de fundição semicontínua, $1^{\circ}$ conjunto de corpos de prova analisados. 126

Figura 83 Corpo de prova número 1 do processo de fundição contínua, $4^{\circ}$ conjunto de corpos de prova analisados.

Figura 84 Curva limite de conformação material acabado, após reavaliação dos pontos dispersos 128

Figura 85 Curva limite de conformação média e a exposta por Davis (2001). 130

Figura 86 Curva limite de conformação Nakazima reduzido. 131

Figura 87 Curva limite de conformação raiz $\left(\mathrm{CLC}_{0}\right)$. 133

Figura 88 Figura de polo (a) Material fresado processo de fundição contínua (220) e (b) Material fresado processo de fundição semicontínua (220) 134

Figura 89 Figura de pólo (a) Material acabado espessura 1,10 mm encruado do processo de fundição contínua (111) e (b) Material acabado espessura 1,10 mole do processo de fundição contínua (111). 135

Figura 90 Função de distribuição de orientação (FDO) do material acabado com espessura $1,10 \mathrm{~mm}$ laminado a frio (encruado) (a) processo de fundição contínua e (b) processo de fundição semicontínua. 136

Figura 91 Função de distribuição de orientação (FDO) do material acabado com espessura $1,10 \mathrm{~mm}$ recozido (a) processo de fundição contínua e (b) processo de fundição semicontínua 138

Figura 92 Fibra de recristalização das chapas na espessura acabada. 139 


\section{LISTA DE TABELAS}

Tabela 1 Resultados de Propriedades mecânicas, latão 70/30 (UNS C26000) (MANDIGO \& SHAPIRO, 1984).

Tabela 2 Composição química das amostras, determinada por fluorescência de raios- $\mathrm{X}$. .70

Tabela 3 Resultados de tamanho de grão obtidos nas bobinas fresadas. .95

Tabela 4 Resultados médios de dureza (HR30T) obtidos na espessura de 1,83 mm, material intermediário no estado encruado. 100

Tabela 5 Resultados de tamanho de grão obtidos nas bobinas intermediárias (Após $85 \%$ de redução de espessura e recozimento), espessura de $1,83 \mathrm{~mm}$....101

Tabela 6 Resultados médios de dureza (HR30T) obtidas na espessura de 1,83 mm, material intermediário mole. 106

Tabela 7 Resultados dos coeficientes de anisotropia planar $\Delta r$ e anisotropia normal $r$ do material intermediário $(1,83 \mathrm{~mm})$, (a) fundição contínua e (b) fundição semicontínua. 108

Tabela 8 Resultados dos ensaios de "orelha", material intermediário mole $(1,83 \mathrm{~mm})$. 109

Tabela 9 Resultados dos ensaios Erichsen, material intermediário mole. 110

Tabela 10 Resultados médios de dureza (HR30T) obtidos na espessura de 1,10 mm, material acabdo no estado encruado

Tabela 11 Resultados médios dos tamanhos de grãos obtidos nas bobinas acabadas.

Tabela 12 Resultados médios de dureza (HR30T) obtidos na espessura de 1,10 mm, material acabado mole.

Tabela 13 Resultados médios dos coeficientes de anisotropia planar $\Delta \mathrm{r}$ e anisotropia normal $r$ dos materiais acabados (a) fundição contínua e (b) fundição semicontínua.

Tabela 14 Resultados médios dos ensaios de orelha, material acabado mole.......121

Tabela 15 Resultados médios dos ensaios Erichsen, material acabado mole. 121

Tabela 16 Resultados médios das propriedades físicas, processo fundição contínua (encruado), espessura 1,83 $\mathrm{mm}$. 153 
Tabela 17 Resultados médios das propriedades físicas, processo fundição semicontínua (encruado), espessura 1,83 mm.

Tabela 18 Resultados médios das propriedades físicas, processo fundição contínua (mole), espessura $1,83 \mathrm{~mm}$.

Tabela 19 Resultados médios das propriedades físicas, processo fundição semicontínua (mole), espessura 1,83 mm. 154

Tabela 20 Resultados dos coeficientes de encruamento (n) e resistência (K) do material mole espessura $1,83 \mathrm{~mm}$ no ângulo $0^{0}$ 155

Tabela 21 Resultados dos coeficientes de encruamento (n) e resistência (K) do material mole espessura $1,83 \mathrm{~mm}$ no ângulo $45^{\circ}$ 155

Tabela 22 Resultados dos coeficientes de encruamento (n) e resistência (K) do material mole espessura $1,83 \mathrm{~mm}$ no ângulo $90^{\circ}$ 155

Tabela 23 Resultados médios das propriedades físicas, processo fundição contínua (encruado - espessura 1,10 mm). 156

Tabela 24 Resultados médios das propriedades físicas, processo fundição semicontínua (encruado - espessura 1,10 mm).

Tabela 25 Resultados médios das propriedades físicas, processo fundição contínua (mole - espessura 1,10 mm).

Tabela 26 Resultados médios das propriedades físicas, processo fundição semicontínua (mole - espessura 1,10 mm) 157

Tabela 27 Resultados médios dos coeficientes de encruamento $(n)$ e resistência (K) do material mole espessura acabada no ângulo $0^{\circ}$

Tabela 28 Resultados médios dos coeficientes de encruamento $(n)$ e resistência (K) do material mole espessura acabada no ângulo $45^{\circ}$ 158

Tabela 29 Resultados médios dos coeficientes de encruamento $(n)$ e resistência (K) do material mole espessura acabada no ângulo $90^{\circ}$ 158 


\section{LISTA DE ABREVIATURAS E SIGLAS}

ASTM American Society for Testing Materials

AGC Automatic gauge control

CFC Cúbica de faces centradas, estrutura cristalina

CLC Curva limite de conformação

CLC $_{0} \quad$ Raiz da curva CLC, corresponde à deformação planar

DIC Digital image correlation

EDE Energia de Defeito de Empilhamento

F.C. $\quad$ Fundição continua

F.S.C. $\quad$ Fundição semicontínua

F.S.C. + L.Q. Fundição semicontínua + Laminação a quente

IRSID Institut de Recherches de la Sidérurgie

UNS The unified numbering system 


\section{LISTA DE SÍMBOLOS}

$\begin{array}{cl}T_{\text {fusão }} & \text { Temperatura de Fusão } \\ \varepsilon & \text { Deformação verdadeira } \\ \varepsilon_{1} & \text { Deformação verdadeira maior no plano da chapa } \\ \varepsilon_{2} & \text { Deformação verdadeira menor no plano da chapa } \\ \sigma & \text { Tensão verdadeira } \\ \mathrm{K} & \text { Coeficiente de resistência e/ou coeficiente da equação de Hollomon } \\ \mathrm{n} & \text { Coeficiente de encruamento e/ou expoente de encruamento } \\ \mathrm{R} & \text { Índice de anisotropia plástica } \\ r & \text { Coeficiente de anisotropia normal } \\ \Delta r & \text { Coeficiente de anisotropia planar } \\ \mathrm{R} \mu & \text { Índice de anisotropia plástica média }\end{array}$




\section{SUMÁRIO}

AGRADECIMENTOS

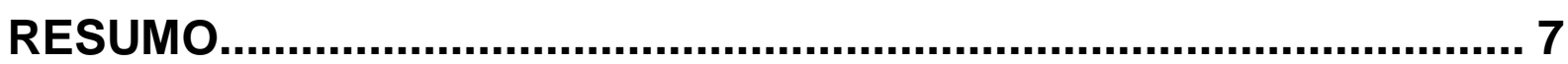

ABSTRACT

LISTA DE ILUSTRAÇÔES............................................................. 10

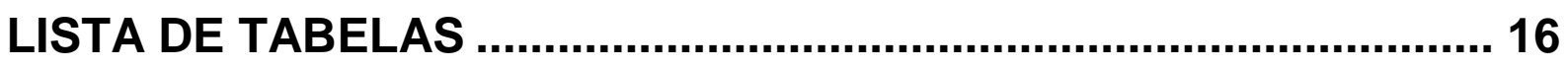

LISTA DE ABREVIATURAS E SIGLAS ........................................... 18

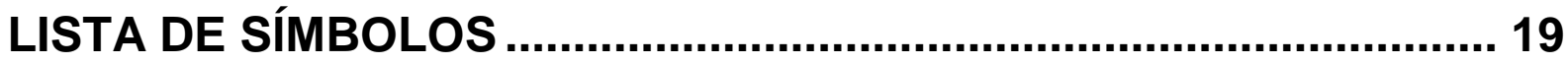

1 INTRODUÇÃO

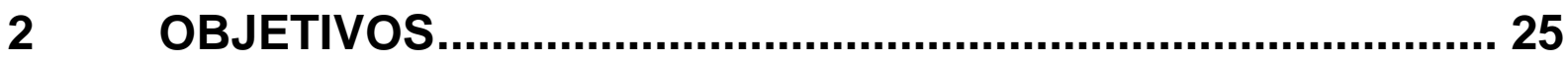

$3 \quad$ REVISÃO DA LITERATURA ............................................... 26

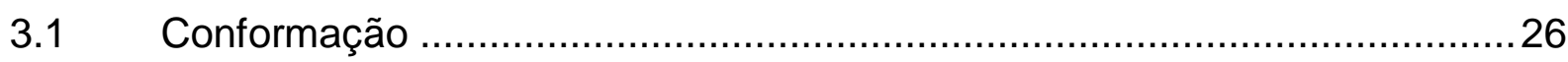

3.1.1 Formação de textura na conformação...................................................28

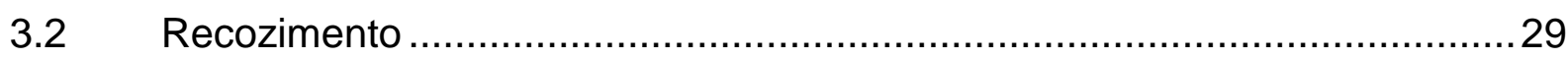

3.2.1 Formação de textura no recozimento .....................................................

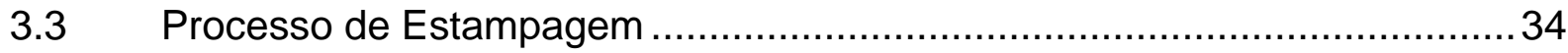

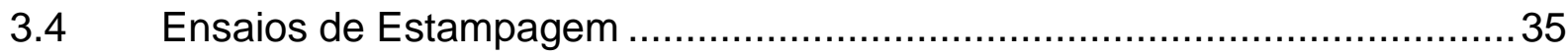

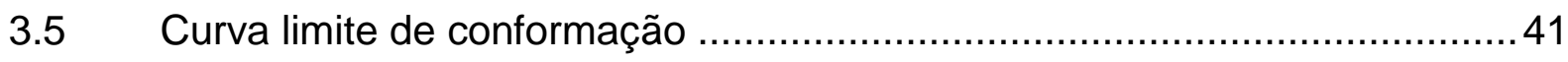

3.6 Variáveis que afetam o levantamento da CLC ........................................50

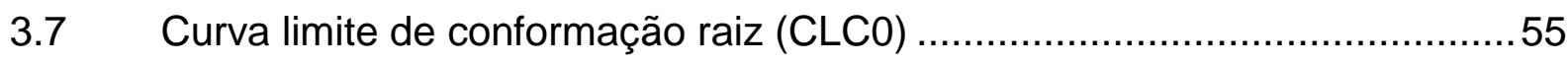

3.8 Curva limite de conformação para cobre e seus ligas...................................59

3.9 Levantamento da curva limite de conformação pelo ensaio de tração

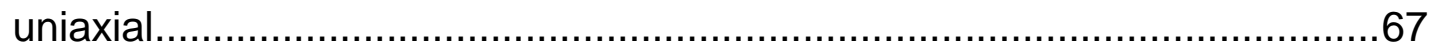

$4 \quad$ MATERIAIS E MÉTODOS ….................................................. 70

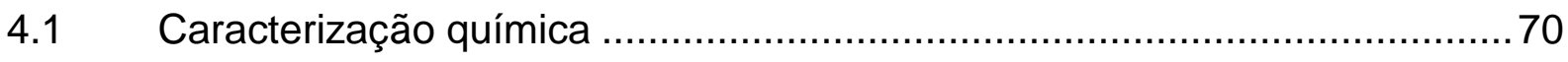

4.2 Processos iniciais de produção fusão e laminação a quente ……………...70

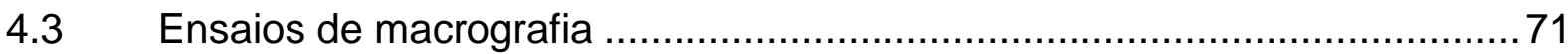

4.4 Processos de fabricação das chapas (laminação a frio e recozimento).......72

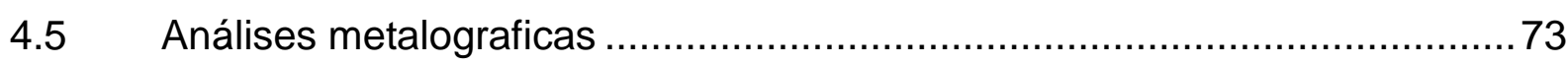

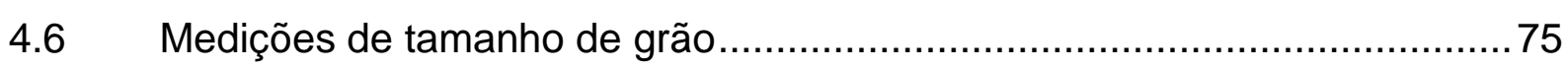


4.7 Preparações dos corpos de prova para ensaios de tração uniaxiais ...........75

4.8 Determinação dos coeficientes de anisotropia planar e normal...................76

4.9 Determinações dos coeficientes de encruamento $n$ e coeficientes de

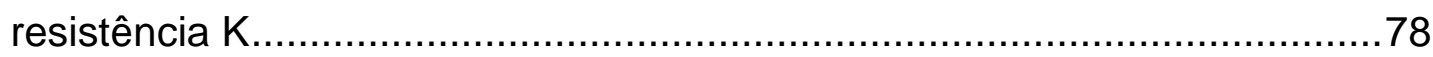

4.10 Ensaio de dureza e levantamento da curva de amolecimento ....................79

4.11 Confecções dos corpos de prova para elaboração da curva limite de conformação através dos ensaios de tração uniaxiais .80

4.12 Confecções dos corpos de prova para elaboração da curva limite de conformação através dos ensaios Nakazima reduzido

4.13 Estampagem dos círculos nos corpos de prova de ensaio de tração uniaxiais (serigrafia)

4.14 Estampagem dos círculos nos corpos de prova de ensaio Nakazima reduzido e ensaio Erichsen (corrosão eletroquímica) 85

4.15 Ensaios para levantamento das curvas limites de conformação (Corpos de prova de tração uniaxiais) 86

4.15.1 Ensaio Erichsen para curva limite de conformação obtida pelo método IRSID. .88

4.17 Ensaios de obtenção da curva limite de conformação raiz $\left(\mathrm{CLC}_{0}\right)$..............90

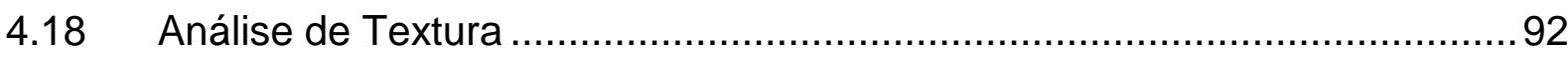

$5 \quad$ RESULTADOS E DISCUSSÃO ............................................ 94

5.1 Caracterização do material como recebido .................................................94

5.2 Caracterização do material encruado (intermediário) .................................97

5.3 Caracterização do material mole (intermediário) ......................................100

5.4 Caracterização do material encruado (acabado) …….............................110

5.5 Caracterização do material mole (acabado) ……….............................113

5.6 Curva limite de conformação obtida pelo ensaio de tração uniaxial (IRSID) e ensaio Erichsen

5.7 Curva limite de conformação obtida pelo ensaio de Nakazima reduzido ... 131

5.8 Curva limite de conformação raiz (CLC0) …........................................132

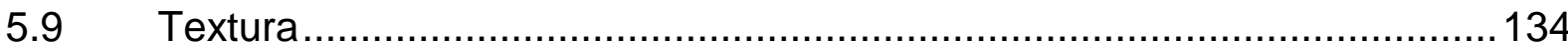

6 CONCLUSÕES ................................................................. 140

7 REFERÊNCIAS.................................................................. 144

APÊNDICE A ............................................................................. 151 


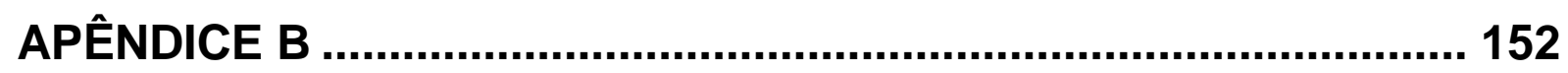

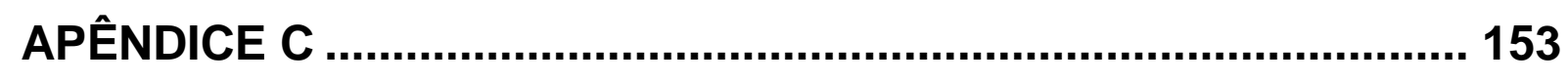

APÊNDICE D

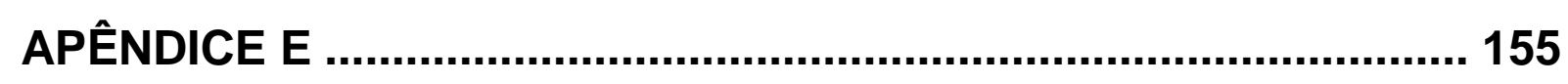

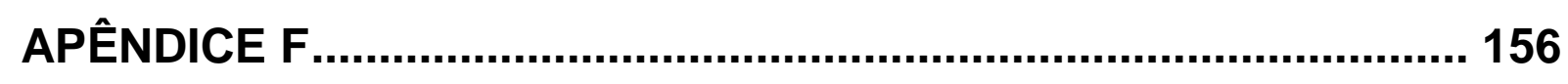

APÊNDICE G

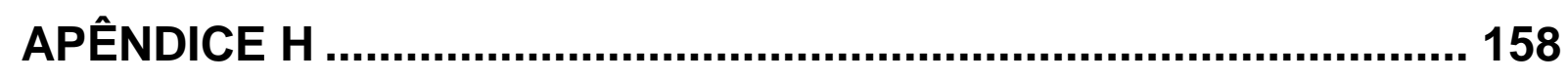




\section{INTRODUÇÃO}

O cobre e suas ligas são considerados como um dos primeiros metais a serem descobertos pela humanidade, descobertas essas que aconteceram, estimase a cerca de 5000 a 7000 anos antes do presente. Sendo assim, uma longa história caracteriza a metalurgia do cobre. Ainda hoje, as tiras e chapas de cobre e suas ligas são consideradas a terceira matéria-prima mais empregada na indústria, superadas apenas pelo aço e alumínio. As principais características obtidas no cobre e suas ligas são; altas condutividades elétrica e térmica, resistência à corrosão e a excelente combinação de resistência mecânica aliada à boa ductilidade, tornando o material extremamente interessante para determinadas aplicações, principalmente para repuxo profundo.

As Usinas de cobre são grandes produtores de semielaborados tais como: tiras, chapas, barras, fios e tubos. As tiras e chapas, objeto deste estudo, são fornecidas para confecções de peças produzidas pelo processo de estampagem, especificamente para a produção de projétil e seus componentes, portanto, devem atender as características especificadas pelas normas ASTM B 130 e ASTM B 131 (AMERICAN SOCIETY FOR TESTING MATERIALS, 2012 e 2013).

A relação entre a aplicação do produto e o processo de manufatura da matéria-prima vem sendo cada vez mais objeto de pesquisa nas indústrias e pelos técnicos envolvidos nos processos, pois o entendimento das propriedades alcançadas e desejadas trazem grandes benefícios, tanto para o produtor como para o consumidor, como a diminuição de refugos em ambos os processos, retrabalhos e consecutivamente a redução de custos, objeto almejado com grande frequência nos dias atuais.

A fabricação de tiras e chapas de cobre podem ocorrer inicialmente através de dois processos distintos: fundição semicontínua (F.S.C.) e/ou fundição continua (F.C.). As bobinas provenientes do processo de fundição semicontínua são fundidas e vazadas em lingoteiras móveis, obtendo-se placas que são posteriormente aquecidas, laminadas a quente, fresadas e finalmente laminadas a frio. As bobinas produzidas pelo processo de fundição continua, não são laminadas a quente, portanto, são fundidas, fresadas e por fim laminadas a frio. 
Para os dois processos iniciais citados neste trabalho, assim como para maioria dos processos fabris, existem vantagens e desvantagens, principalmente econômicas na comparação.

Pelo processo de fundição contínua se obtém uma bobina em rolo que apresenta uma estrutura bruta de fundição com grandes variações de tamanho de grão, pois durante o resfriamento existe a presença das zonas coquilhadas, equiaxiais e colunares, inerentes do processo de fundição e resultantes do gradiente de temperatura durante o resfriamento.

O produto proveniente da fundição semicontínua é uma placa com estrutura bruta de fundição, apresentando uma variação maior ainda entre os grãos devido à grande espessura da placa $( \pm 160 \mathrm{~mm}$ ) e o perfil de extração do calor. As placas originárias do processo de fundição semicontínua são posteriormente laminadas a quente, pois este processo permite grandes reduções e torna possível a obtenção de bobinas com o mesmo dimensional das obtidas no processo de fundição contínua, resultando em uma microestrutura refinada e de grãos de distribuição homogênea quando comprado com o processo de fundição contínua.

Objetivando o entendimento das principais características da liga de latão UNS C22000 para a aplicação de repuxo profundo e principalmente na fabricação de projétil, foram obtidas duas bobinas, sendo uma proveniente do processo de fundição contínua e outra do processo de fundição semicontínua, produzidas pela mesma rota e obedecendo aos mesmos parâmetros, ou seja, mesmo grau de redução (número de passes) entre as etapas de laminação e temperaturas de recozimento nas operações de tratamento térmico intermediário e de acabamento, sendo diferenciadas apenas pelo processo inicial de fabricação F.C. x F.S.C.

Ensaios de estampagem e coeficientes de encruamento $(n)$ e resistência $(K)$ que auxiliam na determinação da estampabilidade das tiras e chapas foram obtidos em todas as etapas de fabricação possíveis, objetivando a diferenciação da estampabilidade entre os materiais estudados. As curvas limite de conformação (CLC) foram determinadas por meio de ensaio de tração uniaxial (lado esquerdo) e ensaio Erichsen (lado direito), os corpos de prova foram propostos pelo IRSID ("Institut de Recherches de La Sidérurgie") com diferentes dimensões e consecutivamente entalhes. Os coeficientes de anisotropia normal ( $r$ ), anisotropia planar $(\Delta r)$, encruamento $(n)$ e resistência $(K)$ foram igualmente determinados. 


\section{OBJETIVOS}

O objetivo do presente estudo é avaliar a estampabilidade de chapas de latão UNS C22000, com espessura final de $1,10 \mathrm{~mm}$, produzidas inicialmente pelo processo de fundição contínua e pelo processo de fundição semicontínua, por meio do levantamento do lado esquerdo da curva limite de conformação realizado através de ensaios de tração (uniaxial), propostos pelo IRSID ("Institut de Recherches de La Sidérurgie") e o lado direito da curva através do ensaio Erichsen. A CLC obtida pelo ensaio Nakazima reduzido em $60 \%$ será também efetuado visando comparar as deformações detectadas em ensaios realizados no plano da chapa e com punção hemisférico. Os coeficientes de anisotropia planar $\Delta r$, normal $r$, encruamento $n$ e resistência $\mathrm{K}$ também serão avaliados em todas as etapas do processo de manufatura das chapas, visando determinar a melhor estampabilidade entre os processos. 


\section{REVISÃO DA LITERATURA}

\subsection{Conformação}

A conformação de metais pode ser definida de diferentes formas, sendo abordada nessa dissertação a conformação proveniente do processo de laminação a frio e o processo de estampagem. A laminação a frio tem como meta a redução da espessura laminada entre as etapas de manufatura das chapas e tiras ou ainda a obtenção de propriedades especificas para determinadas aplicações. A conformação originaria do processo de estampagem, objetiva a forma especifica de peças a serem produzidas. Sendo assim o entendimento do processo de conformação se faz necessário em ambos os casos.

Durante a conformação a frio uma grande quantidade de energia gasta no processo é descartada em forma de calor, em torno de 90 a $98 \%$, sendo absorvida pelo metal apenas os 2 a 10\% restantes. Essa energia é proveniente da geração e a interação do movimento das discordâncias e da presença de lacunas, maclas e de defeito de empilhamento (EDE). Metais com estrutura cristalina cúbica de face centrada (CFC) como, por exemplo, o latão que contém $90 \%$ de cobre e $10 \%$ de zinco, possuem baixa energia de defeito de empilhamento $\left(18 \mathrm{~mJ} / \mathrm{m}^{2}\right)$, quando comparado ao alumínio com 99,99\% de pureza que possui EDE $\approx 200 \mathrm{~mJ} / \mathrm{m}^{2}$ (MOHAMMED, EL-DANAF \& RADWAN, 2006). Ao serem deformados, esses metais apresentam discordâncias de baixa mobilidade em dado que suas discordâncias parciais estão muito afastadas umas das outras, dificultando assim a ativação de fenômenos de superação de obstáculos, como escorregamento com desvio ("crossslip") e escalada ("climb") de discordâncias. Essa baixa mobilidade presente, faz com

que as discordâncias desenvolvidas apresentem uma distribuição plana (homogênea) (PADILHA \& SICILIANO, 1996).

A densidade de discordâncias de um metal com baixa energia de defeito de empilhamento é maior após a deformação plástica em comparação a um metal de alta EDE. O nível da densidade de discordâncias após o processo de conformação é alterado, podendo sair de um patamar de $10^{5}$ a $10^{6} \mathrm{~cm}^{-2}$ para materiais recozidos e atingindo valores em torno de $10^{10}$ a $10^{12} \mathrm{~cm}^{-2}$ para materiais encruados, sendo assim a distribuição das discordâncias é mais uniforme e a energia absorvida na 
deformação é superior quando comparados a materiais de alta energia de defeito de empilhamento deformados da mesma forma (DIETER, 1982);( PADILHA, 2000).

Ao passo que se deforma o material, ocorre o fenômeno de deslizamento e consecutivamente aumenta a tensão necessária para se provocar maior deformação, pois o material apresenta uma deformação prévia, proveniente das etapas anteriores de manufatura. Essa necessidade de aumento na tensão necessária para ocorrer o deslizamento pode ser entendida como o encruamento. $O$ encruamento ocorre devido a dificuldades de movimentação das discordâncias provocadas pela interação entre elas e pelos impedimentos que dificultam sua movimentação através da rede cristalina. Contornos de grão são considerados como obstáculos para as discordâncias, pois as discordâncias não conseguem cruzar os grãos, provocando assim o empilhamento das mesmas nos contornos $\mathrm{e}$ consecutivamente seu aumento na rede cristalina. Átomos de impurezas ou mesmo elementos de liga presentes em solução solida deformam a rede cristalina e os campos de tensão ao seu redor, interagindo com as discordâncias, impedindo também suas movimentações. Esses mesmos átomos de soluto podem baixar a energia de defeito de empilhamento, fazendo com que o material seja mais susceptível ao endurecimento por deformação.

Thornton, Mitchell e Hirsch (1962) e Howie e Swann (1961) demonstram graficamente a variação da energia de defeito de empilhamento em função do aumento da concentração de soluto, obtidos através da medição do raio de curvatura de ligações de discordâncias parciais observadas através de microscopia eletrônica de transmissão e equações matemáticas empíricas, evidenciando que a energia de defeito de empilhamento do cobre puro pode variar de $\cong 40$ a $60 \mathrm{~mJ} / \mathrm{m}^{2}$, já a liga UNS C220000 objeto desse estudo apresenta uma variação bem menor de $\cong 15$ a $18 \mathrm{~mJ} / \mathrm{m}^{2}$, demonstrando uma queda de aproximadamente $67 \%$ entre os valores nominais mencionados. Dieter (1982) também afirma que a energia de defeito de empilhamento diminui com a presença de maiores quantidades de zinco nos latões, portanto, o material em estudo quando comparado ao cobre puro, apresenta um favorecimento ao endurecimento por conformação, devido a menor energia de defeito de empilhamento presente segundo as referências consultadas. 


\subsubsection{Formação de textura na conformação}

A textura pode ser entendida como a orientação cristalográfica preferencial de determinados planos cristalinos ou então pela orientação preferencial dos grãos em um agregado policristalino, cuja origem pode estar em vários tipos de processos de fabricação, como na solidificação, deformação plástica, transformação de fases e recristalização.

Durante a conformação mecânica ocorre o fenômeno denominado deformação plástica principalmente por deslizamento de determinados planos cristalinos, desta forma o reticulado cristalino sofre rotação por deslizamento de planos e/ou por maclação, nas orientações mais favoráveis, estabelecendo a chamada textura de deformação.

A textura desenvolvida na deformação plástica pode ser notada em reduções superiores a $30 \%$, a não ser que o material apresente uma textura advinda do processo anterior de fabricação, desta forma reduções menores já apresentam um nível de textura significativo. Os materiais com as mesmas estruturas cristalinas podem apresentar os mesmos tipos de texturas de deformação, o alumínio e o cobre que possuem estrutura cúbica de face centrada (C.F.C.), apresentam dois tipos de textura mais comuns, sendo a do tipo "latão" e a do tipo "cobre", porém, podem apresentar outros tipos de textura como a tipo "liga", a qual ocorre após altas taxas de deformação. Ligas de latão com zinco até 20\% apresentam textura típicas de transição. (BRESCIANI, SILVA, BATALHA e BUTTON, 2011).

Kallend e Davies (1971) demonstram graficamente na Figura 1 a diferença de textura obtida na deformação para liga de cobre puro, com 10\% de zinco e com 30\% de zinco e no estudo do desenvolvimento de textura em cobre e ligas de cobre e zinco, concluem que a textura inicial é semelhante entre o cobre e as ligas de cobre e zinco estudadas ( $\mathrm{Cu}-10 \% \mathrm{Zn}$ e $\mathrm{Cu}-30 \% \mathrm{Zn})$, porém, para reduções superiores a $40 \%$ a textura de transição se pronuncia muito mais nas ligas $\mathrm{Cu}-10 \% \mathrm{Zn}$ e Cu $30 \% \mathrm{Zn}$. 

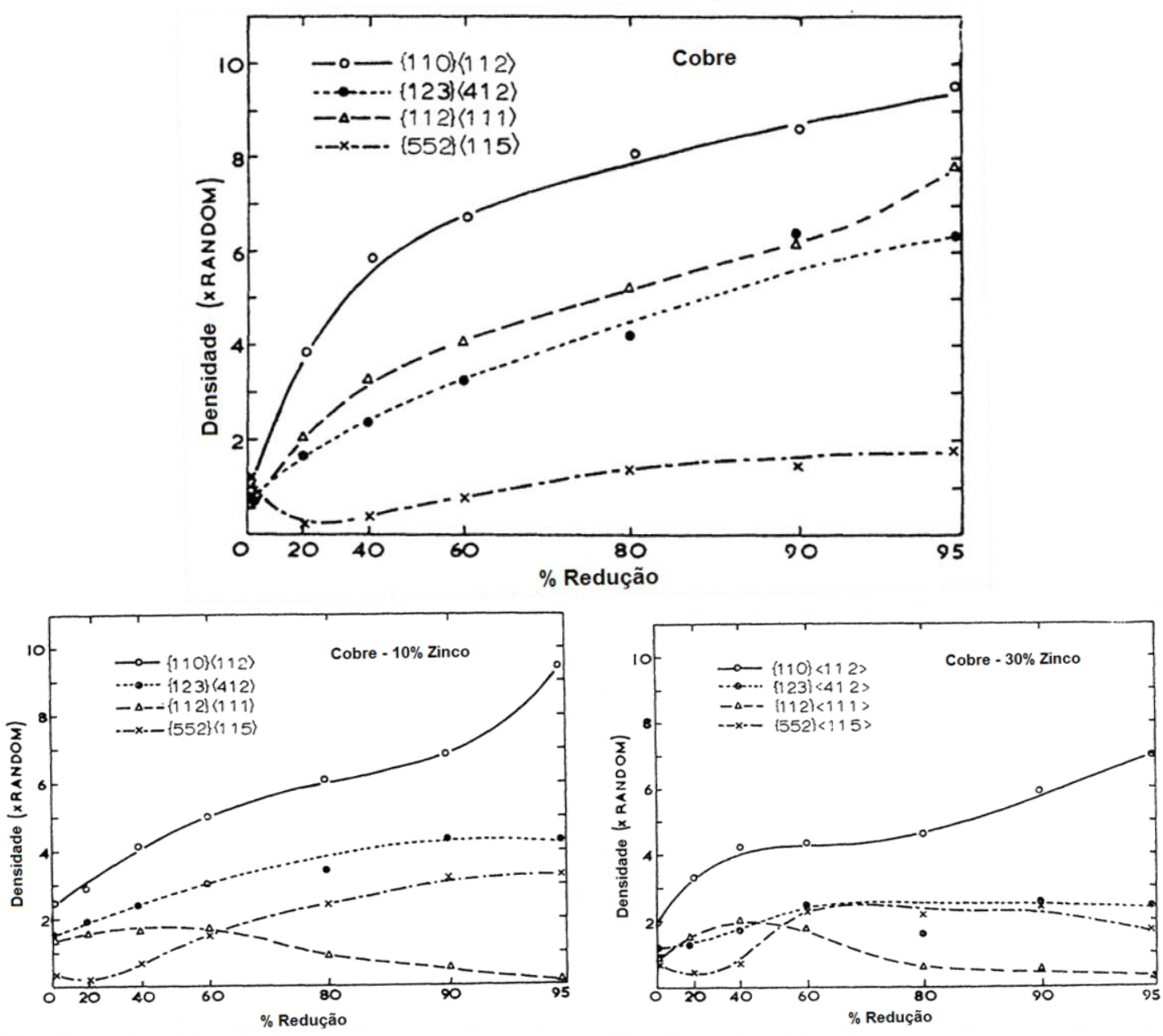

Figura 1 Variação da densidade de orientação de várias orientações ideias com relação à \% de redução na laminação (adaptado de Kallend e Davies (1971)).

El-Danaf et al. (2000) demonstram que a textura de transição cobrelatão obtida no processo de laminação pode ser caracterizada pela diminuição do componente $\{112\}<111>$ acompanhada pelo aumento da densidade de orientação $\{552\}<115>$, podendo ser observado esta afirmação na Figura 1 entre as ligas de cobre-10\% zinco e cobre-30\% zinco e corroborando com a afirmação de Bresciani, Silva, Batalha e Button (2011) cuja textura típica de transição ocorre em ligas de latão com zinco em até $20 \%$.

\subsection{Recozimento}

Conforme descrito anteriormente o encruamento é derivado do processo de conformação mecânica em que o metal é submetido, seja ele por laminação ou pelo 
processo de estampagem de tiras. O surgimento de defeitos como lacunas, maclas, falhas de empilhamento e interação entre discordâncias eleva o nível de energia interna do metal, com isso ocorrem alterações muitas vezes indesejadas nas propriedades mecânicas das chapas para posteriores aplicações. Assim inúmeras vezes, se faz necessário o recozimento das chapas, objetivando-se a restauração das propriedades físicas e mecânicas alteradas durante os processos de conformação. O recozimento é dividido em três etapas importantes; recuperação, recristalização e o crescimento de grão. Davis (2001) evidencia graficamente a influência das três etapas no recozimento com relação à dureza de um liga de latão contendo $95 \%$ de cobre e 5\% de zinco, impondo uma redução de área de $60 \%$ e recozendo a $400^{\circ} \mathrm{C}$, por diferentes tempos (Figura 2).

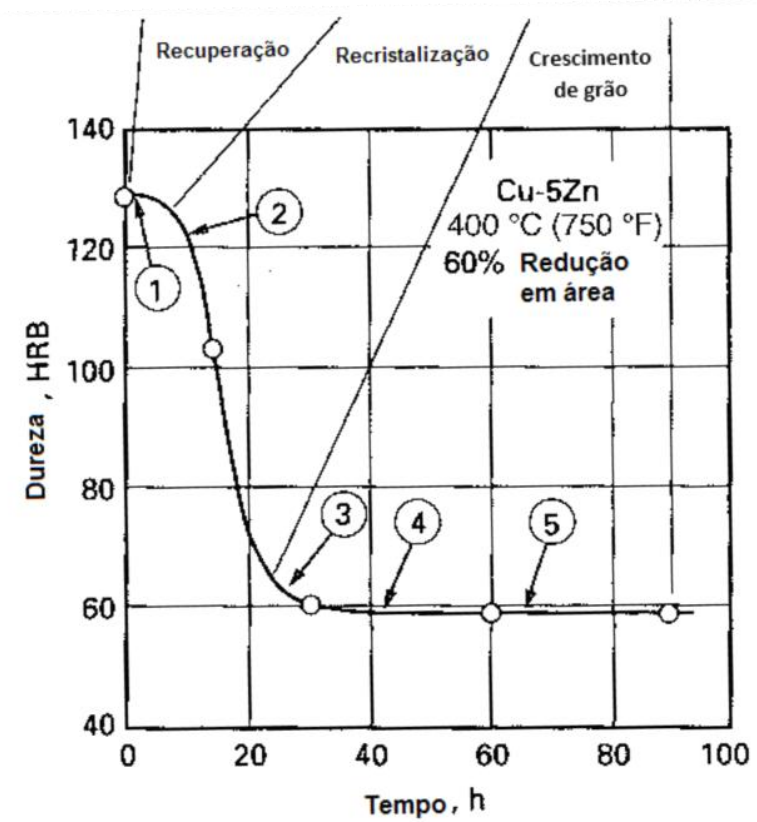

Figura 2 Efeito do tempo de recozimento a $400^{\circ} \mathrm{C}$ na dureza do latão $95 \%$ Cu e $5 \% \mathrm{Zn}$ com $60 \%$ de redução de área. (adaptado de Davis (2001)).

$\mathrm{Na}$ fase de recuperação (1) a dureza diminui levemente, sendo seguido por um decréscimo drástico na dureza durante a recristalização (2), na etapa de crescimento de grão (3), (4) e (5) a dureza continua diminuindo, entretanto, de uma forma mais gradual e com menor variação, durante essa última fase.

Embora a dureza não seja afetada significativamente durante a recuperação, outras propriedades são, por exemplo, a resistividade elétrica, mostrando que as 
mudanças estruturais significativas ocorrem durante esta etapa. Essas alterações, entretanto, não são muito sensíveis à restauração da dureza. Durante a recristalização é observado que o metal está relativamente mais mole, livre de tensões residuais e com baixa densidade de discordâncias, nos cristais formam então núcleos que crescem na matriz deformada plasticamente. Uma vez que a matriz deformada é consumida por estes novos cristais a continuação do recozimento provocará apenas o crescimento dos grãos (DAVIS, 2001).

O processo de recuperação é a primeira e a principal etapa do processo de recozimento dos materiais, sendo ela, portanto, responsável pelas principais alterações ocorridas nos materiais encruados. A energia absorvida durante 0 encruamento é decorrente da formação de defeitos cristalinos advindo da deformação a frio imposta nas tiras e chapas, desta forma a diminuição e o rearranjo desses defeitos se faz necessário nessa primeira fase para que as outras duas ocorram normalmente sem maiores dificuldades. Padilha e Siciliano (1996) descrevem quatro sequencias importantes para a recuperação, na primeira ocorre à diminuição da quantidade de defeitos cristalinos como as lacunas (defeitos puntiformes), a segunda acontece através da aniquilação das discordâncias de sinais opostos e a redução dos anéis de discordâncias, na terceira tem-se o rearranjo das discordâncias, objetivando formar configurações de menor energia e a quarta e última etapa da recuperação a formação de contornos de alto ângulo, tudo isso se deve a difusão atômica ocorrida nas temperaturas utilizadas nos tratamentos térmicos, obtendo o retorno parcial das propriedades mecânicas perdidas na conformação.

A recristalização é a segunda etapa do processo de recozimento, onde ocorrem os processos de nucleação e crescimento de novos grãos, desta forma a ocorrência de rearranjo e difusão de átomos é esperada, assim a temperatura correta é imprescindível para recristalização, pois nesta etapa temos a presença das forças que mantêm os átomos unidos. Dieter (1982) descreve que a densidade de discordância é diminuída na recristalização e os demais efeitos do encruamento são extintos, expõe ainda que a recristalização incide na nucleação de uma região livre de encruamento, cuja adjacência pode transformar a matriz deformada em um material livre de deformação conforme vai se movimentando. Variáveis como, quantidade de pré-deformação, temperatura, tempo, tamanho de grão inicial, 
composição e grau de recuperação ou poligonização anterior ao início da recristalização são importantes e influenciam na recristalização.

Burke e Turnbull (1952) descrevem resumidademente em "Recrystallization and grain growth", as sete leis para recristalização e crescimento de grão, conforme a seguir;

1. Uma deformação mínima é necessária para ocorrer a recristalização.

2. Quanto menor o grau de deformação, maior é a temperatura necessária para ocorrer a recristalização.

3. Aumentando o tempo de recozimento, diminui-se a temperatura necessária para recristalização.

4. O tamanho de grão final depende fortemente do grau de deformação e fracamente da temperatura de recozimento. O tamanho de grão será menor quanto maior for o grau de deformação e quanto menor for a temperatura de recozimento.

5. Quanto maior for o tamanho de grão inicial, maior será o grau de redução necessário para que a recristalização se complete ao mesmo tempo e temperatura de recozimento.

6. O grau de redução necessário para se obter um mesmo endurecimento por deformação aumenta com 0 aumento da temperatura de deformação.

7. O aquecimento por um período maior após a recristalização estar completa, fará com que o tamanho de grão cresça.

Após a completa recuperação e recristalização dos metais durante o processo de tratamento térmico de recozimento, temos o crescimento de grão dos metais, os contornos são considerados potenciais termodinâmicos para o crescimento dos grãos de maneira a diminuir a área total desses contornos, sendo essa diminuição decorrente do crescimento de grão à custa de outros grãos vizinhos.

\subsubsection{Formação de textura no recozimento}

Os recozimentos realizados em baixas temperaturas inferiores $0,48 \mathrm{~T}_{\text {fusão }}$ podem causar apenas a recuperação e pequenas ou nenhuma modificação das 
texturas formadas no processo de conformação efetuado anteriormente. Já os recozimentos realizados em altas temperaturas em torno de $0,57 \mathrm{~T}_{\text {fusão, os quais }}$ causam frequentemente a recristalização, podem causar o aparecimento de uma nova textura, geralmente diferente da textura de deformação. Esta nova textura é conhecida como textura de recristalização (PADILHA \& SICILIANO, 2005).

Stüme e Faustmann (1969) demonstraram no livro "Introducion a las texturas de lós materiales metálicos" não só a influência de textura, mas também a da temperatura de recozimento de latões na formação de "orelha", objeto indesejado na estampagem profunda. $O$ gráfico exposto na Figura 3 demonstra que materiais produzidos com a penúltima temperatura de recozimento superior à última, apresentaram a formação de "orelha" após redução final somente superior a 70\%.

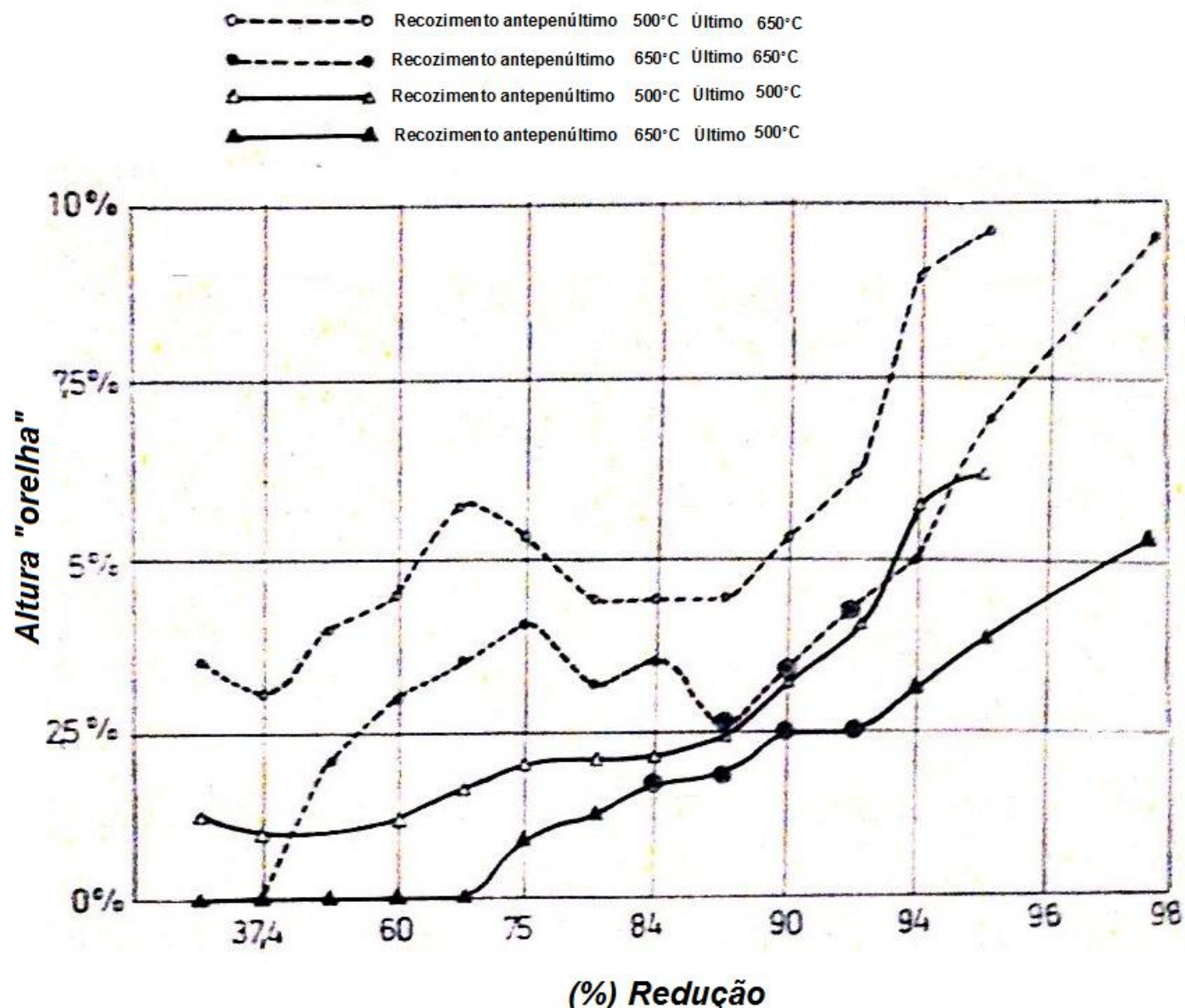

Figura 3 Efeito da temperatura de recozimento e \% redução na formação de "orelha" no latão (adaptado de Stüme e Faustmann (1969)). 
Stüme e Faustmann (1969) expõem que com a adição de apenas 1,28\% de zinco no cobre se observa um forte desvio da textura tipo "cubo" e que os latões possuem texturas de recristalização complicadas que parcialmente podem relacionar-se com tipo "latão".

\subsection{Processo de Estampagem}

O processo de estampagem pode ser definido mecanicamente como um processo responsável pela manufatura de peças com geometrias simples ou complexas através da conformação mecânica de blanks (chapas) sobre uma matriz metálica e seus componentes de alta resistência que possui o formato das peças a serem produzidas, assim como demonstrado na Figura 4. Metalurgicamente pode ser definido como processo de conformação plástica de tiras e chapas, visto que a deformação a ser alcançada durante a estampagem é a plástica e não a elástica.

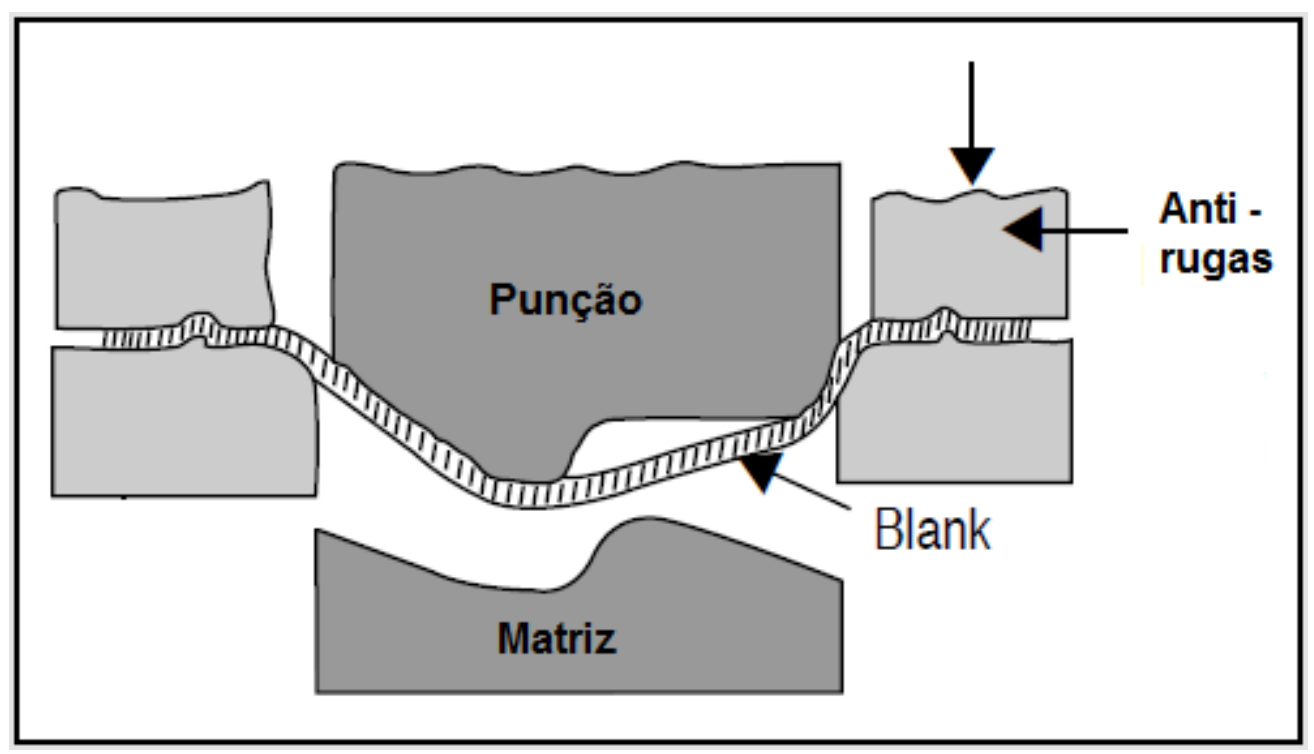

Figura 4 Esquema de seção típica do processo de estampagem (adaptado de HOSFORD e DUNCAN, 1999).

Sua utilização é principalmente a de produção de inúmeros tipos de peças na indústria automobilística, armamento bélico, linha branca e de componentes eletrônicos em geral. As operações de estampagem se dividem basicamente em quatro; corte, dobramento, embutimento e repuxo. Prensas de vários tamanhos e 
forças dão origem à grande quantidade de peças manufaturadas por esse processo. Variáveis como ângulos do ferramental, tipo de lubrificante, velocidade de operação, rugosidade e força são responsáveis por um processo robusto e ideal, além é claro das propriedades físicas e metalúrgicas dos materiais utilizados no processo, haja vista que a busca incessante pela melhoria contínua e redução de custo hoje é objetivo da maioria das organizações.

A influência do tamanho de grão no limite de resistência a tração para ligas de cobre pode ser observada na Figura 5, evidenciando o aumento das propriedades mecânicas com o aumento da quantidade de soluto (zinco) na liga.

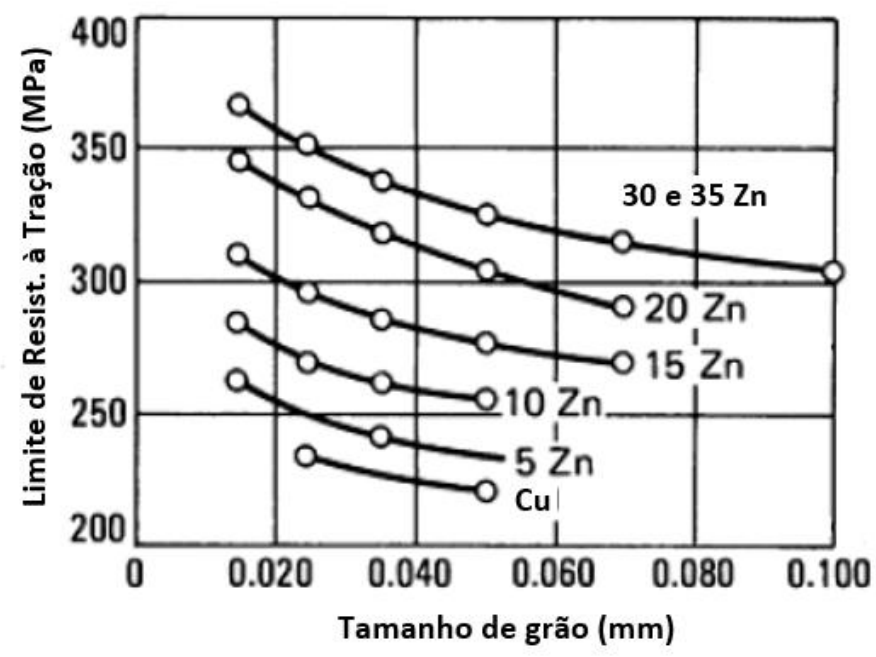

Figura 5 Efeito do tamanho de grão versus limite de resistência à tração de várias ligas de latão recozidas (adaptado de DAVIS, 2001).

\subsection{Ensaios de Estampagem}

Durante a manufatura de chapas utilizadas para o processo de estampagem é possível realizar uma grande quantidade de ensaios que possibilita a previsão de possíveis falhas a serem ocorridas posteriormente à fabricação de peças estampadas. Porém, mesmo assim é possível encontrar problemas devido às complexidades dos produtos elaborados, caminhos percorridos pelo material durante a deformação, pois os testes são realizados em equipamentos de pequeno porte $\mathrm{e}$ se obtém apenas um parâmetro, não podendo prever o comportamento da chapa em condições desiguais daquela de ensaio. Sugere-se realizar mais de um tipo de 
ensaio, realizando uma comparação entre os resultados obtidos e correlacionandoos com a peça produzida em escala industrial. A elaboração da curva limite de conformação exposta a seguir no texto pode ser considerada como uma das melhores ferramentas para avaliação da estampabilidade das chapas, devido à previsão de deformação suportada pelo material durante o processo de produção e podendo ser realizado seu levantamento na própria peça produzida pela indústria.

Os ensaios realizados nas chapas utilizadas no processo de estampagem podem ser divididos em dois ou três grupos. Plaut (2003) e Taylor (1988) dividem em dois grupos, ensaios intrínsecos, os quais não dependem da espessura e muito menos das condições superficiais, e os ensaios simulativos, sendo sensíveis à espessura, condições superficiais, lubrificantes, tipo e geometria do ferramental. Usiminas (1999) divide em três grupos, testes simulativos, testes relativos às propriedades básicas do material e por última avaliação da "severidade" da deformação, sendo os dois últimos grupos iguais ao de ensaios intrínsecos expostos por Palut (2003) e Taylor (1988), portanto, serão expostos apenas os dois grupos;

Ensaios Intrínsecos - Ensaio de tração uniaxial, objetiva a obtenção do limite de resistência à tração, limite de escoamento em determinada porcentagem ( $\varepsilon=0,2 \%$ ), alongamento em determinado comprimento $(50,80 \mathrm{~mm})$ e redução de área, em conformidade com a norma ASTM E 8.

Os coeficientes $\mathrm{n}$ e $\mathrm{K}$ são também determinados pelo ensaio de tração uniaxial através da norma ASTM E 646. O n é definido como o coeficiente de encruamento e o K como coeficiente de resistência, sendo ambos obtidos através da curva tensão x deformação verdadeira, na zona plástica demonstrada através de uma relação potencial (Figura 6) simples exposta inicialmente por Hollomon (Dieter, 1982);

$$
\sigma=K \varepsilon^{n}
$$

O valor de $\mathrm{n}$ pode variar de 0 a 1 , materiais com valores próximo a 1 apresentam desempenho superior no processo de estampagem, ou seja, o material apresenta uma maior capacidade de encruamento e uma distribuição mais uniforme das deformações mediante um gradiente de tensões, sem que provoque 0 rompimento das tiras e/ou chapas durante o processo de estampagem. $\mathrm{O}$ K também possui o mesmo comportamento, porém, sua variação é bem diferente. Mandigo e 
Shapiro (1984) obtiveram através da equação de Hollomon para o latão 70/30 em seu estado recozido, com tamanho de grão médio de $40 \mu \mathrm{m}$, espessura de 0,68 mm um valor de $\mathrm{n}$ a $0^{\circ}$ do sentido de laminação de 0,56 e um valor de $\mathrm{K}$ de $865 \mathrm{MPa}$, os valores de $n$ nos outros ângulos $45^{\circ}$ e $90^{\circ}$ apresentam valores superiores em $5 \%$ do valor detectado a zero grau no sentido de laminação e os valores de $\mathrm{K}$ apresentaram-se $5 \%$ a menos do detectado a $0^{\circ}$. Ghosh e Hecker (1975) obtiveram para o latão 70/30 na espessura de $0,94 \mathrm{~mm}$, no estado recozido não especificando o tamanho de grão um valor de $n$ de 0,47 , para o latão $61 / 39$ na espessura de $0,88 \mathrm{~mm}$ um valor de $\mathrm{n}$ de 0,43 , podendo ser evidenciado a diminuição do $\mathrm{n}$ pela espessura, teor de cobre, zinco ou tamanho de grão não especificado pelos autores. A norma ASTM E 2218 expõe o valor de n para um latão 70/30, com espessura de $1,143 \mathrm{~mm}$ e limite de resistência a tração de $349 \mathrm{MPa}$ demonstrando um valor de 0,397. Gracio, Fernandes e Rocha (1987) determinaram para o cobre desoxidado com alto teor de fósforo, liga UNS C12200 o valor de n através do critério de Hill para estado de tensão no plano da chapa, assumindo que o material é isotrópico obtendo o $\mathrm{n}$ por meio da equação $\delta_{e}=k\left(\varepsilon+E_{0}\right)^{n \frac{*}{\varepsilon} m} \mathrm{n}$ igual a 0,36 , já a liga de alumínio 2024, submetida ao tratamento térmico T3, possui um valor de $\mathrm{n}$ de $0,17 \mathrm{e}$ um valor de $\mathrm{K}$ de $780 \mathrm{MPa}$, demonstrando um comportamento bem diferente dos latões e do cobre (Dieter, (1982)).

$\sigma \times \varepsilon_{\text {(convencional) }} \operatorname{e} \times \varepsilon_{\text {(verdadeira) }}$ UNS C 22000

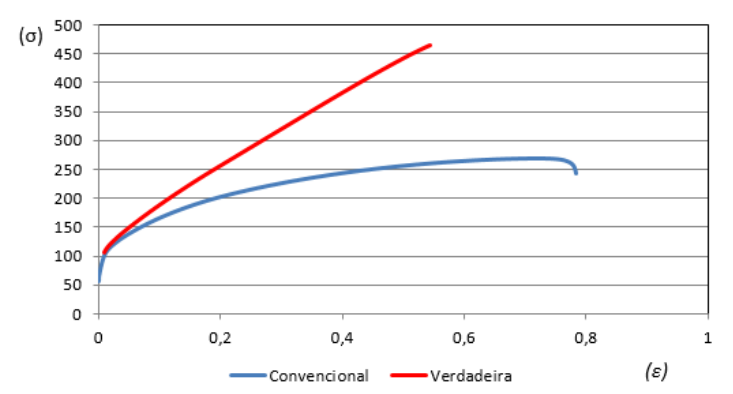

$\sigma \times \varepsilon(\log )$

UNS C22000

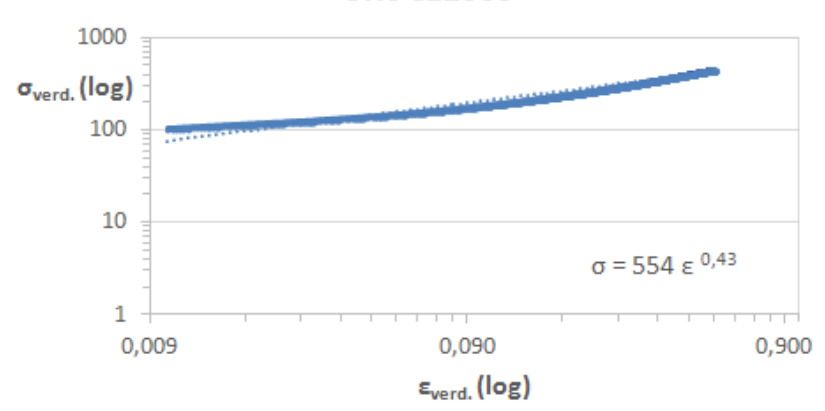

Figura 6 Comparação das curvas de tensão-deformação convencional e tensão-deformação verdadeira e curva tensão-deformação na base log.

O índice de anisotropia plástica $R$ ou $R$ de Lankford, como também é conhecido, deve ser determinado nos ângulos $0^{\circ}, 45^{\circ}$ e $90^{\circ}$ com relação a direção 
de laminação, sendo obtidos através do ensaio de tração uniaxial e em conformidade com a norma ASTM E 517, para posterior obtenção dos coeficientes de anisotropia planar $\Delta \mathrm{r}$ e anisotropia normal $\mathrm{r}$. Os índices de anisotropia plástica são obtidos através da medição da largura e espessura na região central dos corpos de prova, antes e após a deformação especificada pela norma entre 10 a 20\%, sendo os coeficientes calculados conforme as equações a seguir;

$$
\begin{gathered}
r=\frac{\ln \left(\frac{L_{f}}{L_{i}}\right)}{\ln \left(\frac{e_{f}}{e_{i}}\right)} \\
r_{m}=\frac{\left(r_{0}+2 r_{45}+r_{90}\right)}{4} \\
\Delta r=\frac{\left(r_{0}+r_{90}-2 r_{45}\right)}{2}
\end{gathered}
$$

Desta forma torna-se possível a previsão da formação de "orelha" e afinamento nas chapas analisadas. Por apresentar certa rapidez aliada à eficiência este método é muitas vezes utilizado pelas Usinas produtoras de aços e metais não-ferrosos como o cobre e suas ligas.

Ensaios simulativos - São ensaios cujo objetivo é realizar a simulação mais próxima do processo real de estampagem, desta forma, os números de variáveis que influenciam os ensaios são grandiosos como; acabamento superficial do material e do ferramental (rugosidade), condições de lubrificação, velocidade de deformação e geometria da peça a ser fabricada.

Os principais ensaios simulativos utilizados para determinação da estampabilidade das chapas são Erichsen, Olsen, Swift, Fukui, Teste de Bulge, Dobramento, Orelha.

O ensaio de formação de uma calota, conhecido na Europa como Erichsen (vide Figura 7) e nos Estados Unidos como Olsen, sendo diferenciados apenas pelo diâmetro do punção de $20,00 \mathrm{~mm}$ para o Erichsen e 22,22 mm para o Olsen, é o teste mais antigo, utilizado desde meados de 1914 em decorrência de sua agilidade e simplicidade operacional, possuindo quase nenhuma influência do analista nos valores encontrados (USIMINAS, 1999). Sua determinação pode ser efetuada segundo a norma ASTM E 643, a qual expõe algumas variáveis importantes como a faixa de espessura ("thickness range") que o ensaio pode ser efetuado 0,20-2,00 $\mathrm{mm}$, a lubrificação apenas do punção, a velocidade de ensaio de 0,08 - 0,40 mm/s, 
a dureza do punção, não sendo inferior a 65 HRC, o acabamento superficial do punção não deve conter uma rugosidade superior a $160 \mu$ m e o número de amostras a serem ensaiadas é no mínimo três.

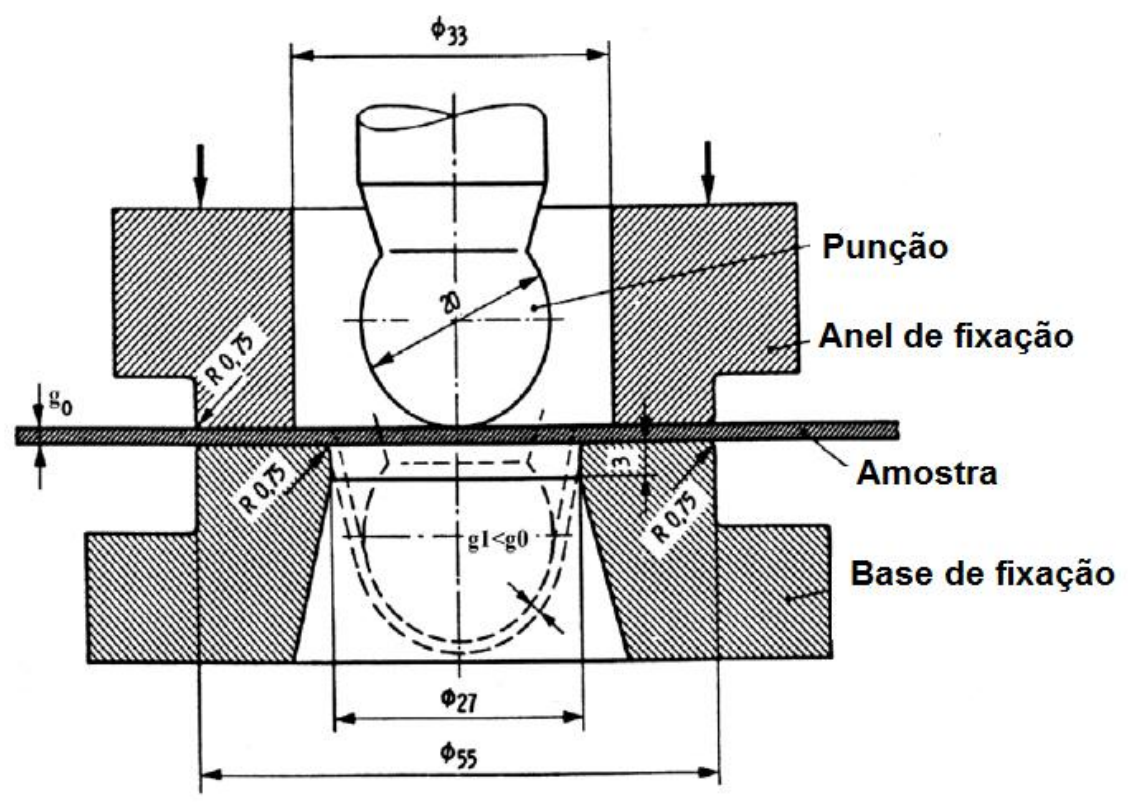

Figura 7 Esquema do ensaio Erichsen (adaptado de GRAVUS et al., 2010).

As ligas de cobre possuem forte correlação com índice Erichsen em relação ao tamanho de grão do material e com a espessura da chapa analisada, a Figura 8 demonstra as duas afirmações aqui expostas. A Figura 8.a demonstra a correlação índice Erichsen versus tamanho de grão de um latão 70:30 na espessura de $1,07 \mathrm{~mm}$, a Figura 8.b demonstra amostras de tamanho de grão $30 \mu \mathrm{m}$ variando a espessura de 0,25 a $2,30 \mathrm{~mm}$.

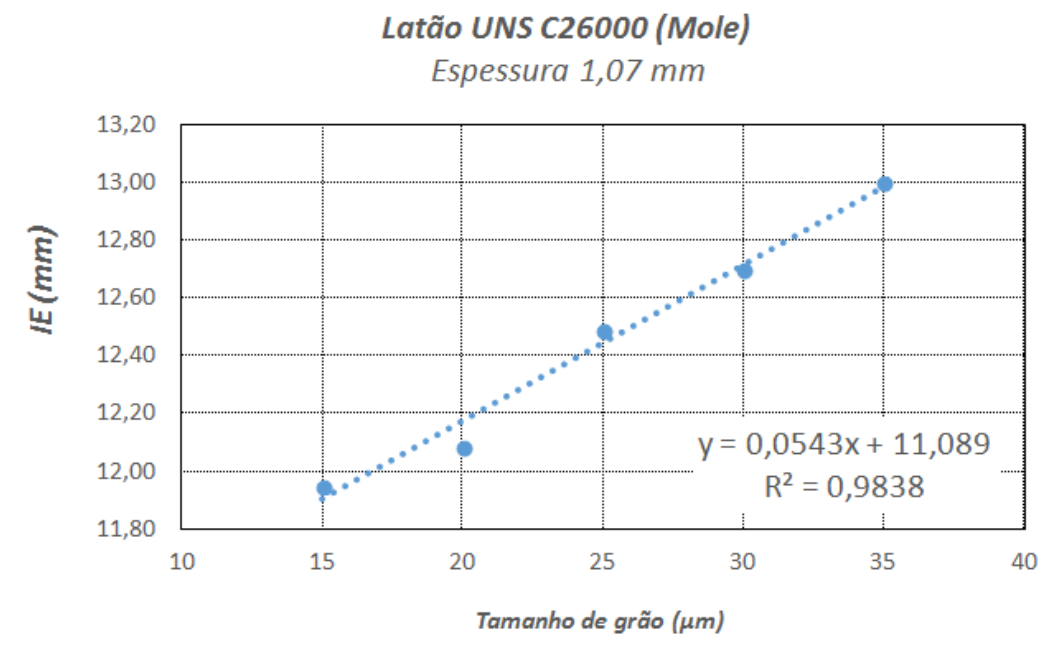

(a) 


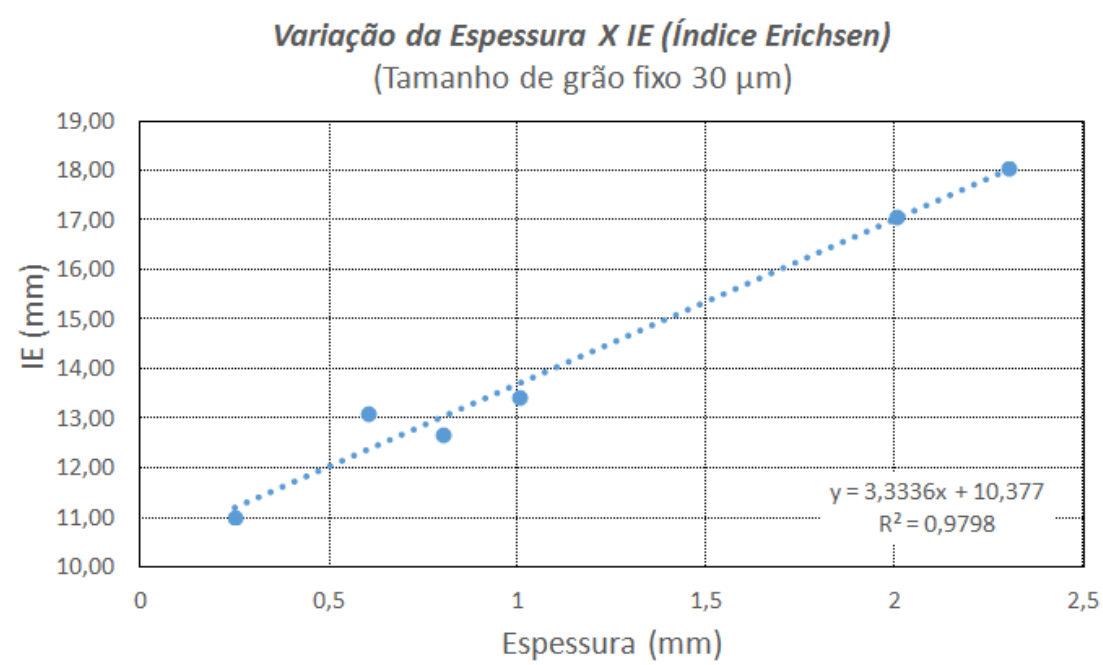

(b)

Figura 8 Índice Erichsen x tamanho de grão e espessura para o latão 70:30.

Como o próprio nome sugere o ensaio de orelha ("earing test") tem como objetivo avaliar a possível formação de orelha nas tiras e chapas fornecidas para indústria da estampagem, a norma ISSO 11531, demonstra a forma que o ensaio deve ser realizado e a forma que o resultado deve ser interpretado, variáveis como as espessuras a serem ensaiadas de 0,1 a 3,00 mm são descritas pela norma, a dureza do punção deve ser de no mínimo 750 HV 30, a lubrificação das duas superfícies das amostras e o cálculo da porcentagem de "orelha" obtida no ensaio.

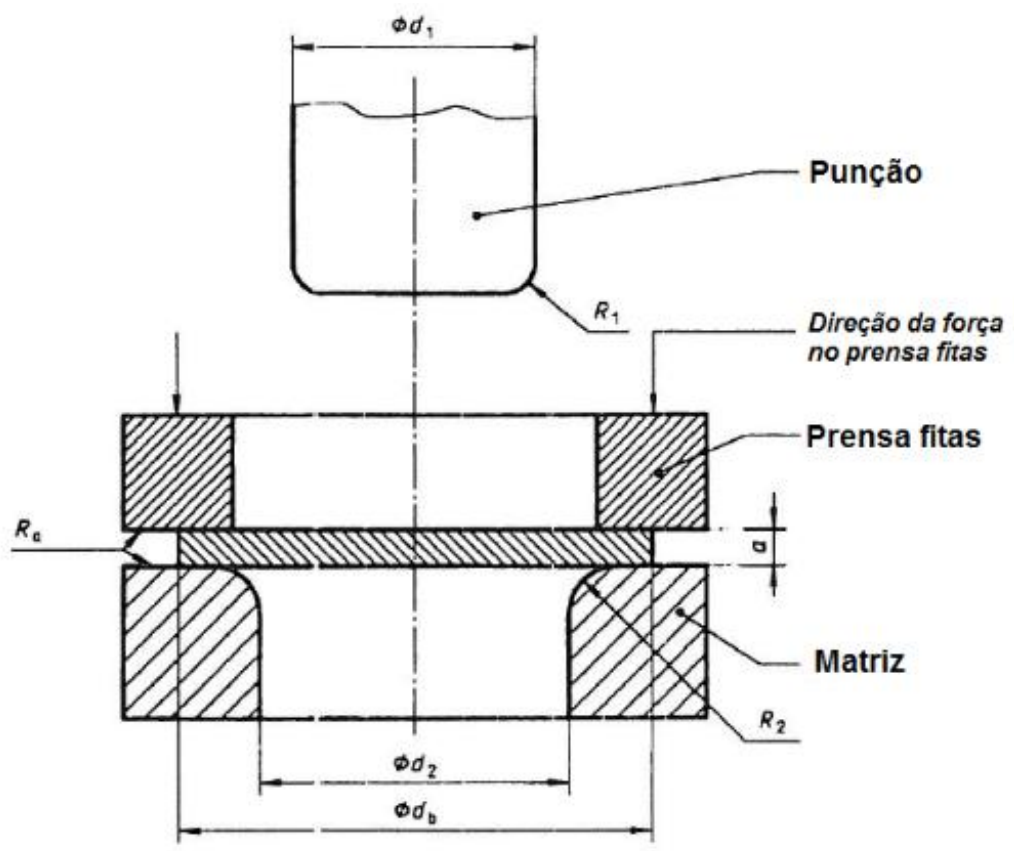

Figura 9 Esquema de ensaio de "orelha" (adaptado da ISSO 11531, 2015). 
A presença da formação de orelha é decorrente da diferença de propriedades mecânicas entre os diferentes ângulos com relação ao sentido de laminação e da textura predominante presente na chapa, tornando o fenômeno de formação de orelha existente, esse teste é rápido e prático e se obtém excelente reposta ao ser realizado, sendo extremamente correlacionável com o ensaio de obtenção do coeficiente de anisotropia planar $(\Delta r)$.

\subsection{Curva limite de conformação}

A curva limite de conformação (CLC) é utilizada como uma ferramenta de grande valia na indústria de estampagem e principalmente para fabricação de peças na indústria automobilística, responsável pela sua descoberta. Seu objetivo principal é verificar o lugar correspondente geometricamente dos máximos pontos de deformação de uma determinada chapa metálica submetida a esforços, representando de maneira ampla a estampabilidade de um determinado material. Posteriormente serão abordadas outras possíveis previsões de ocorrências de falhas observadas através das curvas limites de conformação.

Schön (2013) expõe que um grande avanço alcançado no processo de estampagem ocorreu devido à descoberta do surgimento da estricção, associado a valores críticos das duas deformações principais no plano da chapa, em um ensaio de estiramento realizado por Keeler e Backofen em 1963.

Esta descoberta está associada ao lado direito da curva limite de conformação $\left(\varepsilon_{2}>0\right)$. O lado esquerdo $\left(\varepsilon_{2}<0\right)$ foi determinado por Goodwin somente em 1968. Desde então, a curva limite de conformação vem sendo chamada de diagrama de Keller-Goodwin e sofrendo inúmeras evoluções com relação à forma de obtenção dos dados (ensaios), vide a Figura 10.

Estudos detalhados das curvas limites de conformação nos permite verificar inúmeros caminhos de deformação como balanço biaxial, deformação plana, tensão uniaxial, tensão pura e compressão uniaxial, podendo associar possíveis falhas com possíveis caminhos de deformação conforme exposto a seguir. 


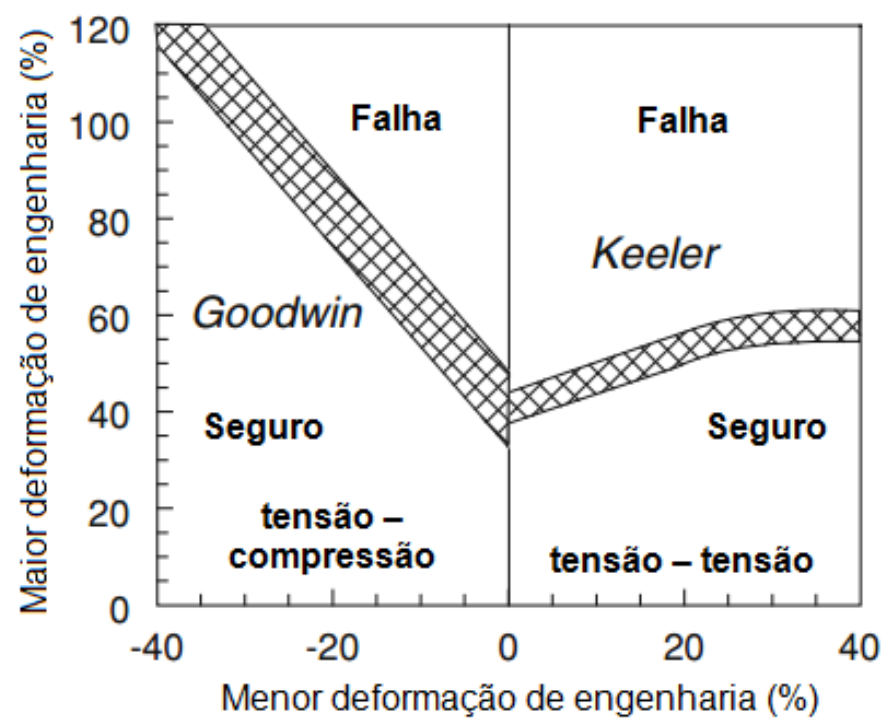

Figura 10 Curva limite de conformação, descoberta. (adaptado de EMMENS, 2011)

Keeler (1994) demonstra na Figura 11 através de um diagrama de deformação verdadeira maior $\left(\varepsilon_{1}\right)$ plotada na vertical versus deformação verdadeira menor $\left(\varepsilon_{2}\right)$ plotada na horizontal as possíveis deformações principais obtidas na curva limite de conformação de acordo com o posicionamento das deformações na curva.

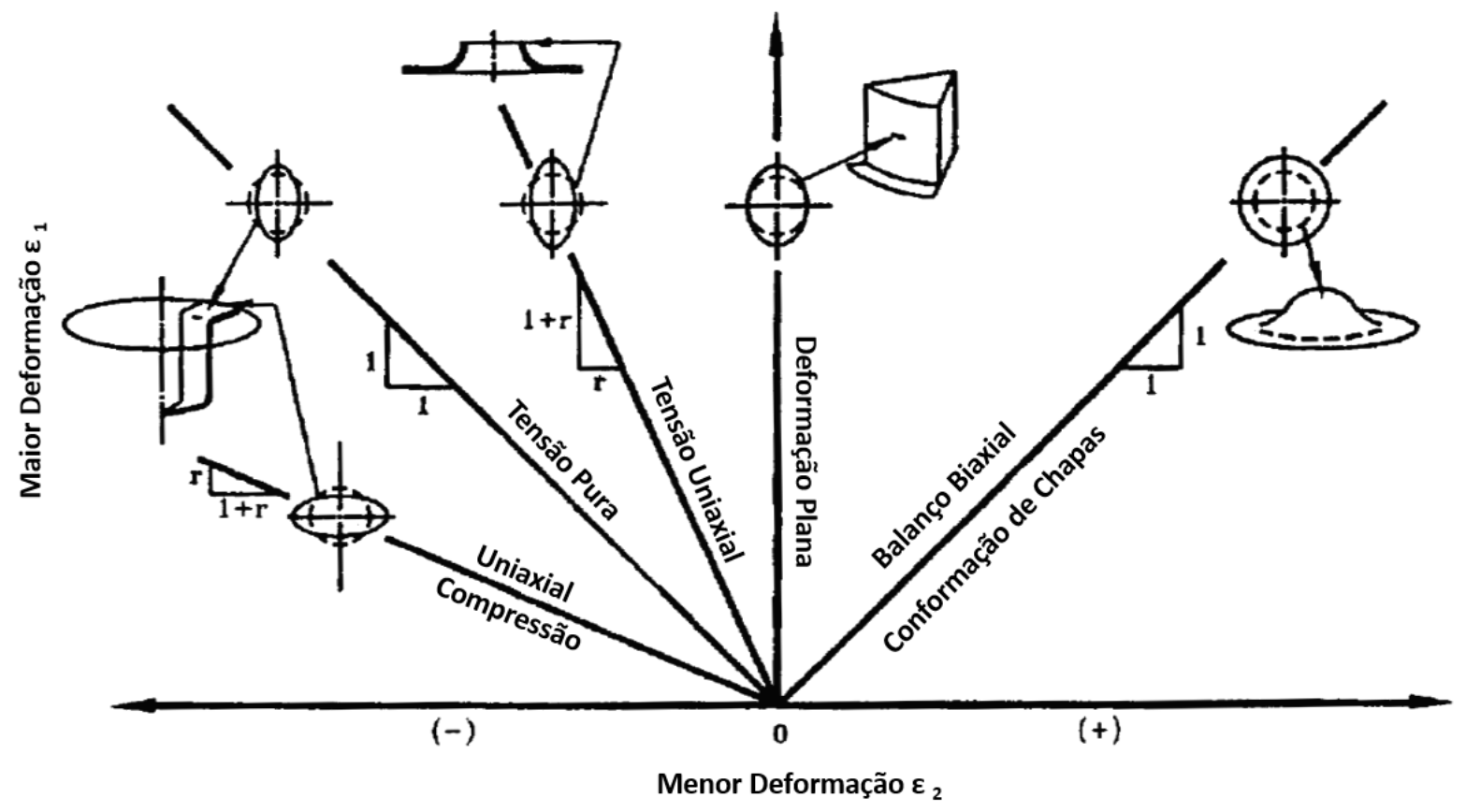

Figura 11 Diagrama representativo das deformações principais expostas na curva limite de conformação (adaptado de KEELER, 1994). 
Cinco caminhos de deformação são demonstrados na Figura 11, sendo o primeiro, do lado direito para o lado esquerdo, o estiramento biaxial (balanço biaxial) - geralmente acontece devido ao contato da matriz com a peça ou no caso dos ensaios no contato da amostra com o punção hemisférico e/ou hidráulico. No comprimento e na largura obtêm-se deformações trativas de valores iguais, já a deformação obtida na espessura será compressiva correspondendo à superioridade em dobro da deformação do comprimento ou da largura.

Deformação plana - das deformações expostas no diagrama, a deformação no plano da chapa é uma das mais importantes, pois estatísticas da indústria automobilista apontam que $80 \%$ a $85 \%$ das falhas ocorridas na estampagem de peças são em decorrência deste tipo de deformação. Para este plano a menor deformação no plano da chapa é zero $\left(\varepsilon_{2}=0\right)$. O caminho desta deformação é comumente criado em uma chapa conformada sem que ocorra o contato do metal com a parede da peça ou do punção. Não existe deformação na direção do comprimento nem tão pouco da largura, existe apenas deformações trativas, existindo deformação compressiva na direção da espessura (FOLLE, ARRUDA, MARCA \& SCHAEFFER, 2008); (XAVIER, PLAUT \& SCHÖN, 2014); (AYRES, BRAZIER \& SAJEWSKI, 1979).

Tensão uniaxial - É o estado de tensão evidenciado no ensaio de tração, cuja principal característica são as deformações tratativas no sentido do comprimento e deformações compressivas na largura e na espessura, sendo as deformações na largura e na espessura iguais entre si.

Tensão pura - A maior deformação é equilibrada pela menor deformação compressiva, desenvolvendo uma tensão na espessura próxima a zero.

Compressão uniaxial - Este caminho da deformação é o inverso da tensão uniaxial e é encontrada na retração da borda comumente encontrada em torno da periferia de um blanck circular, na estampagem de um copo cilíndrico.

Hosford e Duncan (1999) demonstram esquematicamente na Figura 12 as deformações nas curvas limites de conformação e na própria peça estampada, exemplificando a descrição dos parágrafos anterior e consecutivamente facilitando 0 entendimento da curva e de aplicações reais. 

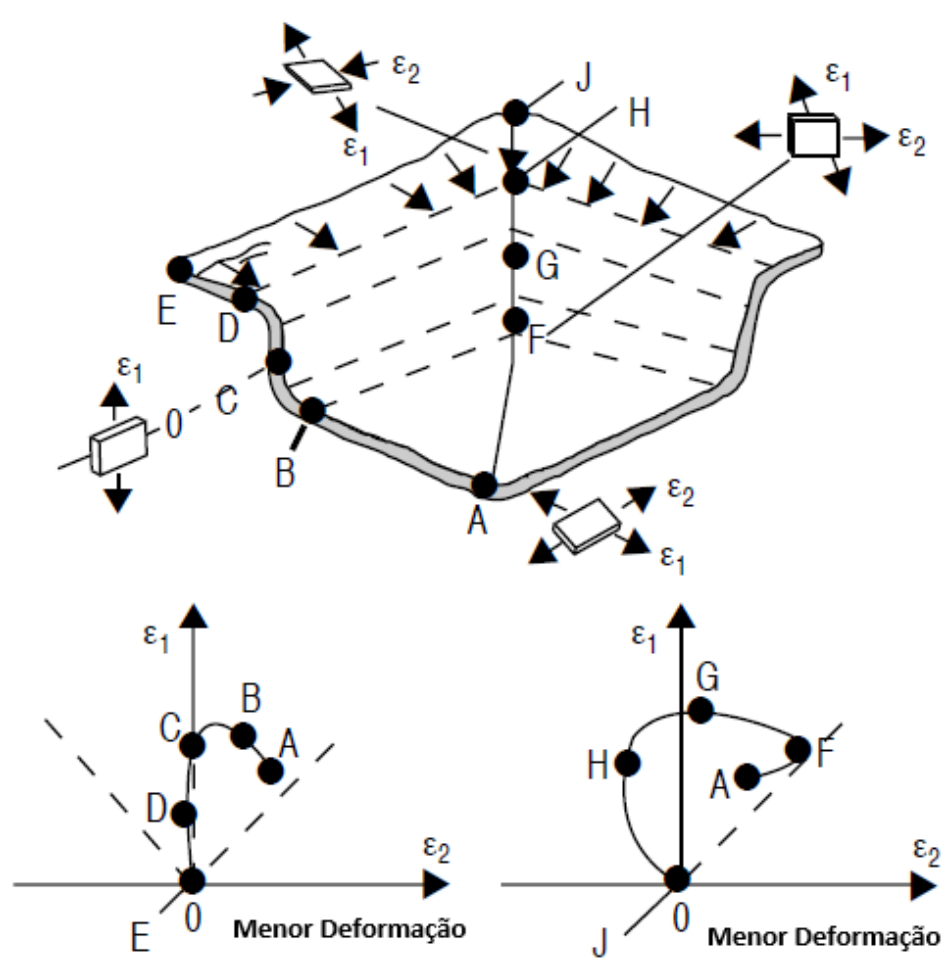

Figura 12 Peça estampada e seus possíveis caminhos de deformação identificados nas curvas limites de conformação (adaptado de HOSFORD e DUNCAN, 1999).

A CLC permite a interpretação não apenas da fratura mais sim de possíveis ocorrências não desejadas, sendo muito utilizada na indústria automobilística conforme já mencionado em função dos produtos manufaturados, baixo custo quando comparado com "try-out" e por apresentar excelente previsão de sucesso do material a ser empregado (TISZA \& KOVÁCS, 2012).

A interpretação da curva é extremamente importante por apontar possíveis ocorrências como ruptura da chapa (fratura), afinamento excessivo, enrugamento e estiramento insuficiente. Holmberg, Enquist e Thilderkvist (2003), construíram uma curva limite de conformação didática, demonstrando na Figura 13 especificamente o posicionamento de possíveis ocorrências na chapa avaliada. 


\section{Major strain $\varepsilon_{1}$}

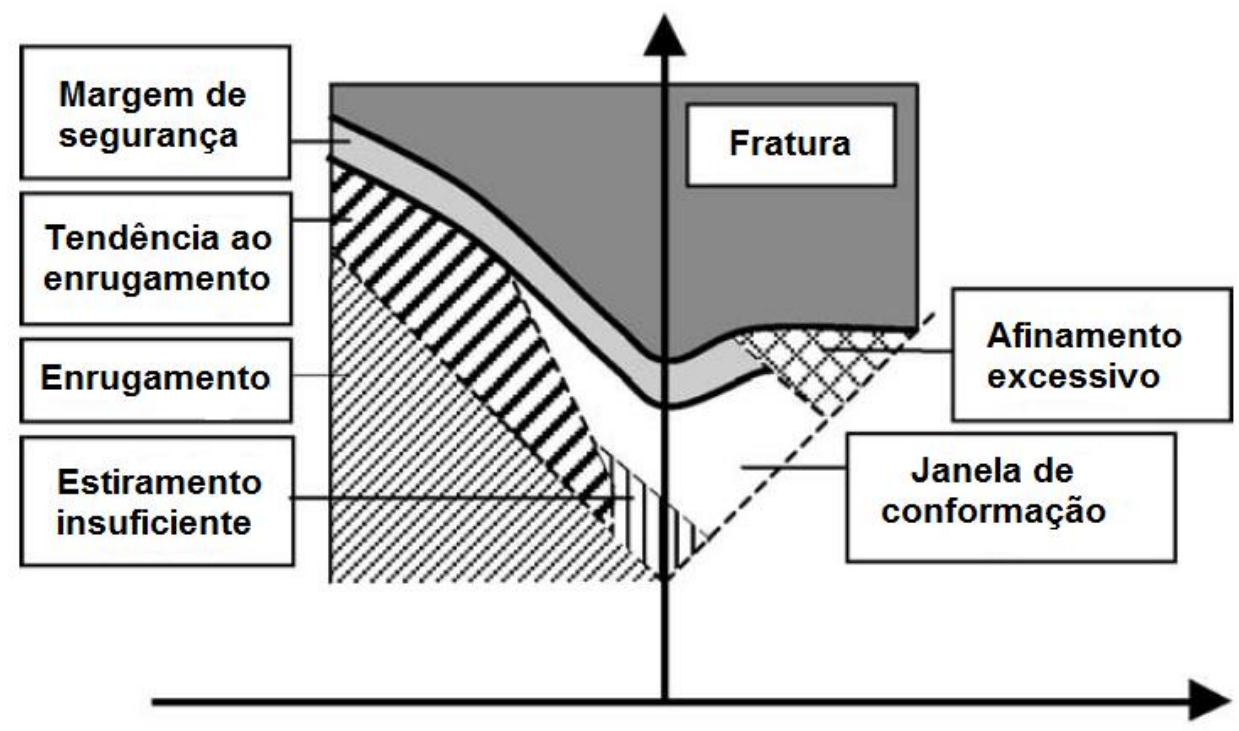

\section{Minor strain $\varepsilon_{2}$}

Figura 13 Curva limite de conformação demonstrando o local de possíveis ocorrências (adaptado de HOLMBERG; ENQUIST; THILDERKVIST, 2003).

Os dados para a elaboração das curvas limite de conformação são atualmente obtidos por vários tipos de ensaios distintos, como o proposto pelo IRSID ("Institut de Recherches de la Sidérurgie") e objeto de estudo da presente pesquisa, desenvolvido pelo laboratório central de pesquisas do grupo siderúrgico Frances Usinor. Nesta metodologia, os dados são coletados por meio de ensaios de tração (uniaxial) com corpos de prova de diferentes geometrias, possuindo entalhes conforme a Figura 14. Os ensaios Erichsen, Olsen, Fukui e Swift também podem ser empregados no levantamento das curvas.

$\mathrm{Na}$ metodologia proposta pelo IRSID o lado esquerdo da curva limite de conformação é obtida pelo ensaio de tração uniaxial através dos quatro corpos de prova demonstrados na Figura 14, ou seja, são estampados círculos nas regiões centrais de entalhe dos corpos de prova e calculado as deformações $\varepsilon_{1}$ e $\varepsilon_{2}$ após os ensaios. Para obtenção do lado direito da curva, utiliza-se os ensaios Erichsen, Olsen, Fukui e Swift com diferentes punções e geometria dos punções. No presente estudo utilizou-se apenas o ensaio Erichsen, portanto, obteve-se apenas um ponto do lado direito das curvas limites de conformação. 

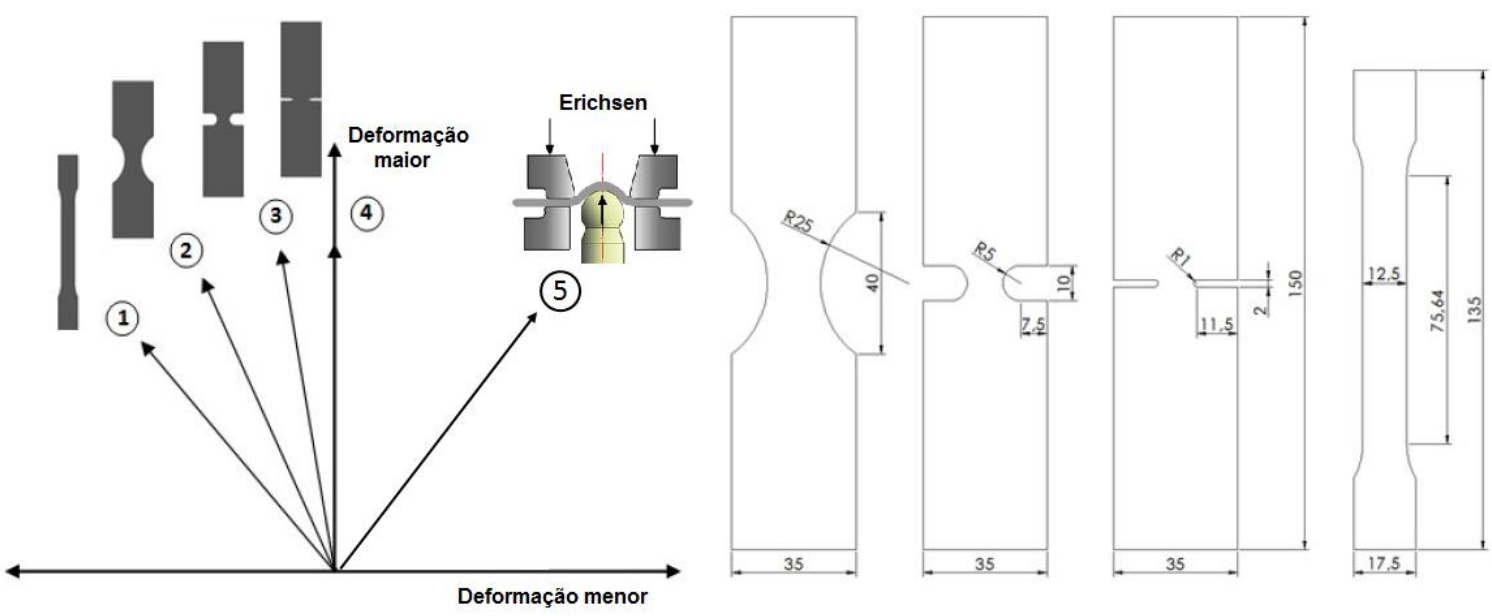

Figura 14 Corpos de prova utilizados para o levantamento da curva limite de conformação de acordo com o método proposto pelo IRSID (adaptado de Schwindt et al (2015)).

Em 1967, Marciniak propôs um ensaio de embutimento que leva o seu próprio nome, com um punção de fundo plano e corpos de prova de diferentes geometrias. Assim como Marciniak, um ano mais tarde, em 1968, Nakazima propõe um ensaio similar, porém com punção de formato hemisférico, nomeado também com o próprio nome do autor e bastante utilizado atualmente. Os corpos de provas possuem diferentes dimensões assim como os utilizados nos ensaios de tração.

Alguns softwares de simulação como o AutoForm (Forming Reality), apresentam alguns inconvenientes como desconsiderar as alterações microestruturais como aumento da densidade de defeitos cristalinos e da textura cristalográfica ocorridas durante a deformação plástica dos materiais, provocando desta forma dúvida nos resultados obtidos (XAVIER, 2014). Kaluza, Kim e Bleck (2002) expõe a diferença entre os softwares ABAQUS e AutoForm, no processo de obtenção da curva limite de conformação. O AutoForm utiliza elementos 2D com uma espessura virtual da peça e/ou corpo de prova, já o ABAQUS utiliza elementos 3D, cuja, representação da geometria é real, podendo efetuar o cálculo da tensão e deformação de forma mais próxima da real.

Uma nova técnica vem sendo empregada também para a obtenção da CLC que é a digital image correlation, conhecida como DIC (Correlação de imagem digital), Hijazi, Yardi e Madhavan (2004), utilizaram está técnica através do ensaio de estiramento Domo hemisférico com corpos de prova de diferentes entalhes 
(largura variando de 102 a $25 \mathrm{~mm}$ ), descrevendo que esta técnica possui maior precisão, quando comparada com a técnica de elementos finitos, pois monitora a tensão e deformação durante todo ensaio nas três dimensões. Os ensaios foram efetuados em chapas de alumínio liga 2024-O, objetivando avaliar a influência da espessura, lubrificação e anisotropia na curva limite de conformação obtida.

Xu et al (2014) utilizaram o DIC para efetuar o levantamento da curva limite de conformação em micro-chapas de cobre "puro" (UNS C11000) com diferentes espessuras e tamanhos de grãos, utilizando como base o método conhecido como Holmberg's descrito como maior ênfase no texto a seguir. Segundo os autores o tamanho de grão exerce grande influência nas curvas em decorrência das mínimas espessuras das chapas utilizadas neste processo. O aumento do tamanho de grão para espessuras finas diminui o limite de deformação suportado pelo material, sendo possível detectar deformações localizadas e não homogêneas nos ensaios, decorrentes do surgimento de "voids" (vazio), ainda mais com uma grande relação espessura/diâmetro do grão.

Inúmeras são as formas de levantamento das curvas, sendo assim cada processo de obtenção das curvas possui suas particularidades e diferenças, a Figura 15 nos permite verificar certa dispersão dos dados obtidos pelos ensaios de Marciniak x Nakazima em função do dimensional dos punções utilizados durante os ensaios e, portanto, diferenças nos caminhos de deformação.

Os punções utilizados nos ensaios Marciniak e Nakazima se diferem, sendo utilizado no ensaio Marciniak punção de cabeça plana e punção de cabeça esférica no ensaio Nakazima, desta forma obtém-se deformações diferentes para o mesmo material em função do dobramento da chapa na região de contato da chapa entre o punção. 


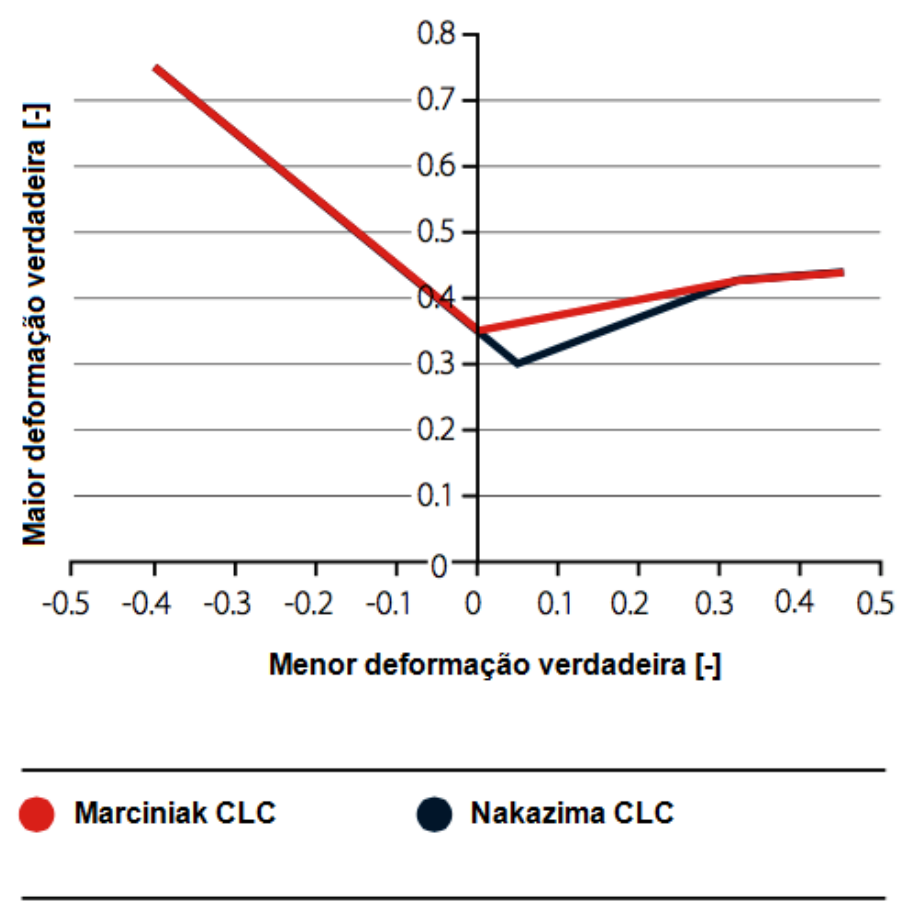

Figura 15 Comparação da curva limite de conformação obtida pelo ensaio de Marciniak e Nakazima (adaptado de TATA Steel, 2013).

Assim como a diferença apresentada entre os ensaios de Marciniak e Nakazima o ensaio de tração (uniaxial) desenvolvido pelo IRSID, também apresenta diferenças na obtenção da CLC quando comparado com o ensaio de Nakazima (Figura 16), devido ao gradiente de deformação extremamente alto na região de entalhe dos corpos de prova de tração e de não ser possível estampar círculos de diâmetros pequenos objetivando compensar esses gradientes de deformação (USIMINAS, 1999).

A Figura 16 demonstra uma diferença significativa nos processos de obtenção das curvas limites de conformação apenas no lado esquerdo, em função dos corpos de prova de ensaio de tração uniaxial utilizados. As geometrias dos corpos de prova são fundamentais para se obter grandes deformações, os raios de curvatura dos entalhes dos corpos de prova devem ser tais que aliviem a maior concentração de tensão possível, pois desta forma possibilita a maior deformação alcançada pelo corpo de prova e se aproxima dos resultados detectados nos ensaios realizados com punções (HOLMBERG; ENQUIST; THILDERKVIST, 2003). 


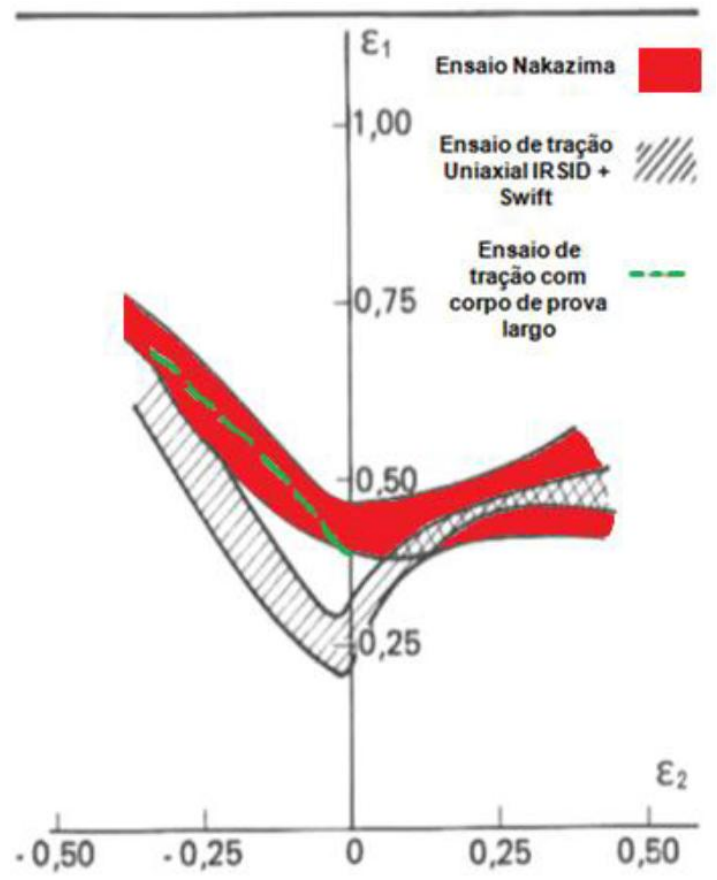

Figura 16 Comparativo da curva limite de conformação obtida pelo método IRSID x Nakazima e tração com corpo de prova de largo (USIMINAS, 1999).

Schwindt et al (2015) realizaram no aço DP-780 um estudo comparativo da determinação da curva limite de conformação, obtida através de ensaios de tração uniaxial, com corpos de prova igual aos propostos pelo IRSID e o ensaio de Nakazima reduzido, ou seja, todo o ferramental utilizado nos ensaios e os corpos de prova foram reduzidos em $60 \%$ do exposto na norma ISO 12004-2. As deformações medidas nos corpos de prova de ensaio de tração foram determinadas pela técnica DIC (Digital image correlation), já as deformações medidas nos corpos de prova do ensaio Nakazima, foram obtidas de forma tradicional, com a gravação eletroquímica de diâmetros de 2,50 mm e as medições após os ensaios efetuadas em lupa de 20X aumento. A principal conclusão é que existe uma diferença de $70 \%$ entre as deformações planares obtidas em função das metodologias utilizadas nos ensaios, corroborando mais uma vez que existe diferença entre as formas de obtenção das curvas.

Conforme já mencionado a obtenção da curva pode ser efetuada de várias formas, desde que seja tomado todos os cuidados referenciados até aqui. $\mathrm{A}$ construção da CLC é efetuada através da obtenção das deformações verdadeiras $\varepsilon_{1}$ e $\varepsilon_{2}$, sendo a deformação verdadeira $\varepsilon_{1}$ determinada através da medição da direção transversal $\left(90^{\circ}\right)$ no sentido de laminação e a deformação $\varepsilon_{2}$ pela medição da 
direção longitudinal $\left(0^{\circ}\right)$, nos círculos/elipses estampados nos corpos de prova conforme expostos na Figura 17.
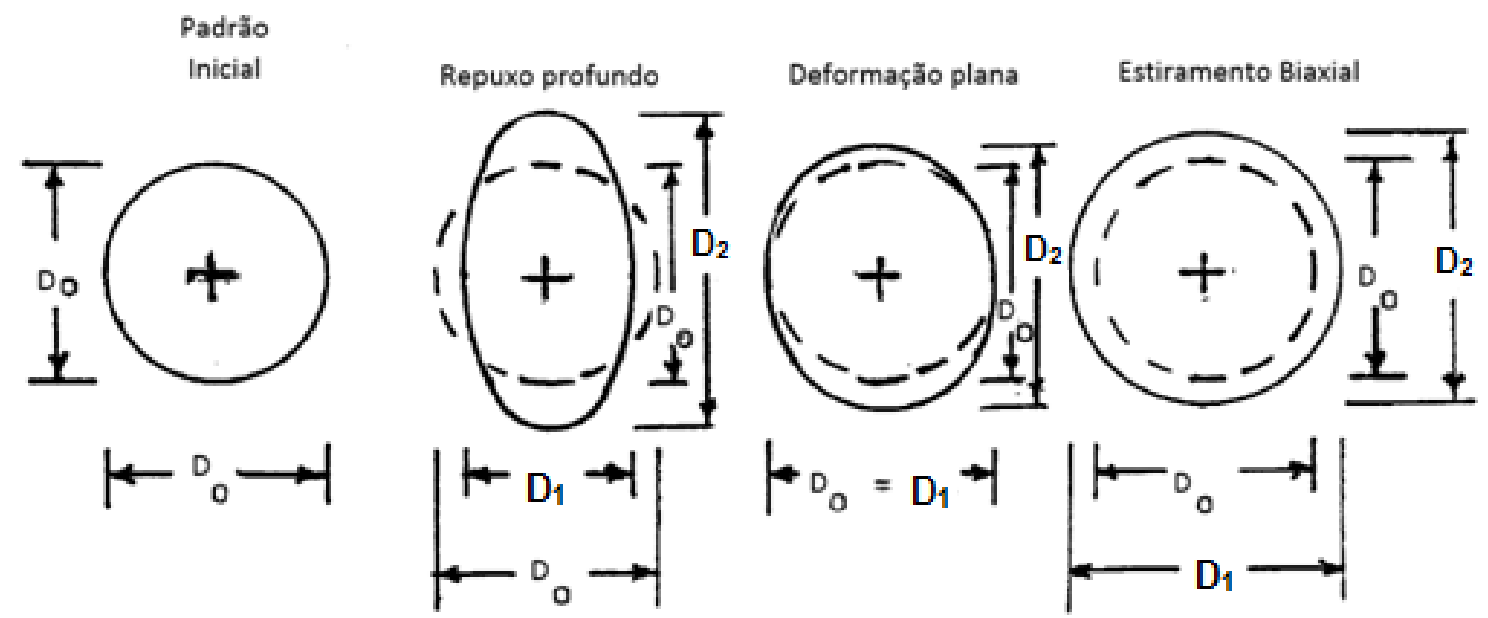

Figura 17 Formato de medição do diâmetro dos círculos antes e após os ensaios (adaptado: ASTM E 2218).

Os resultados obtidos nas medições dos círculos antes e após a deformação dos corpos de prova, serão utilizados no cálculo das deformações verdadeiras $\varepsilon_{1}$ e

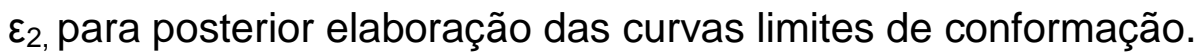

$$
\begin{aligned}
& \varepsilon_{1}=\ln (1+e 1) ; e 1=\left(\frac{\mathrm{D}_{1}-\mathrm{D}_{0}}{\mathrm{D}_{0}}\right)(5) \\
& \varepsilon_{2}=\ln (1+e 2) ; e 2=\left(\frac{\mathrm{D}_{2}-\mathrm{D}_{0}}{\mathrm{D}_{0}}\right)(6)
\end{aligned}
$$

Os valores obtidos para cada corpo de prova são então plotados em uma curva de $\varepsilon_{1} \times \varepsilon_{2}$.

\subsection{Variáveis que afetam o levantamento da CLC}

Assim como na maioria dos processos e ensaios, o levantamento da curva limite de conformação deve ser efetuado de forma clara e concisa, pois o número de variáveis que influenciam na sua obtenção e sua real validação é muito grande, sem contar as variáveis que são correlacionáveis com a curva e estão diretamente relacionadas com a estampabilidade da chapa a ser analisada. 
Os principais fatores que influenciam a avaliação da estampagem e consecutivamente o levantamento das curvas limites de conformação são (ASTM E2218, 2015); (IRSID, 1975); (FOLLE et al, 2008); (PLAUT, 2003); (XU et al, 2014); HOSFORD \& DUNCAN, 1999); (MELANDER, 1983);

1. Precisão da gravação dos círculos nas amostras.

2. Tamanho dos círculos.

3. Espessura das chapas.

4. Coeficiente de atrito.

5. Sentido de retirada das amostras no plano da chapa.

6. Tamanho de grão das chapas.

7. Coeficiente de encruamento $n$.

A precisão dos métodos para gravação de rede de círculos nas amostras é muito importante, pois é através deles que são efetuadas as medições das deformações, antes e após a conformação das amostras. Geralmente utiliza-se o processo de corrosão eletroquímica para gravar as redes de círculos. Os processos de serigrafia, impressão fotográfica e roto-gravura também podem ser utilizados, porém, o alto custo dos processos acaba se tornando um empecilho.

Xavier, Sousa, Lopes e Plaut (2006), efetuaram a comparação entre três metodologias de gravação de círculos para estudos de estampabilidade efetuada através das curvas limites de conformação: corrosão eletroquímica, serigrafia e rotogravura foram às técnicas analisadas. Os processos apresentaram particularidades prós e contras suas aplicações. A corrosão eletroquímica, possui baixa nitidez antes e após o processo de conformação, porém é a técnica mais barata. A Serigrafia apresenta certa rapidez e custo mediano, porém, para deformações biaxiais, com a presença de atrito há deformidades indesejadas dos círculos neste processo, pois causam erros na determinação das deformações. A roto-gravura possui alto custo e possíveis problemas de trincas, durante a deformação plástica e após certos tempos de exposição ao cloreto férrico, porém, é o processo que possui melhor nitidez seja na deformação uniaxial como na deformação biaxial, com ou sem a presença de atrito e um estudo prévio de tempo de exposição ao cloreto férrico pode sanar este tipo de problema.

Como já mencionado, o círculo é um item muito importante na obtenção das deformações, pois influencia desde seu tamanho, como a sua nitidez antes e após a 
deformação visando detectar de forma correta a deformação para construção da CLC. Em 1975 o IRSID publicou uma coleção de investigação do aço junto à comunidade europeia, expondo a metodologia de levantamento da CLC através de ensaio de tração (uniaxial) e ensaios de Fukui e Swift, demonstrando uma curva limite de conformação com diferentes tamanhos de círculos $\varnothing=4,77, \varnothing=3,92$, $\varnothing=0,94, \varnothing=0,46$ e $\varnothing=0 \mathrm{~mm}$, utilizados na obtenção das curvas, comprovando que com os círculos com diâmetros grandes se obtém uma menor deformação de forma geral e as curvas apresentam um formato de "parábola", diferentemente das outras curvas, podendo concluir-se que quanto menor o diâmetro da rede de malhas desenhada, maior será a deformação medida e menor a chance de ocorrerem variações de deformação dentro do círculo medido (Figura 18).

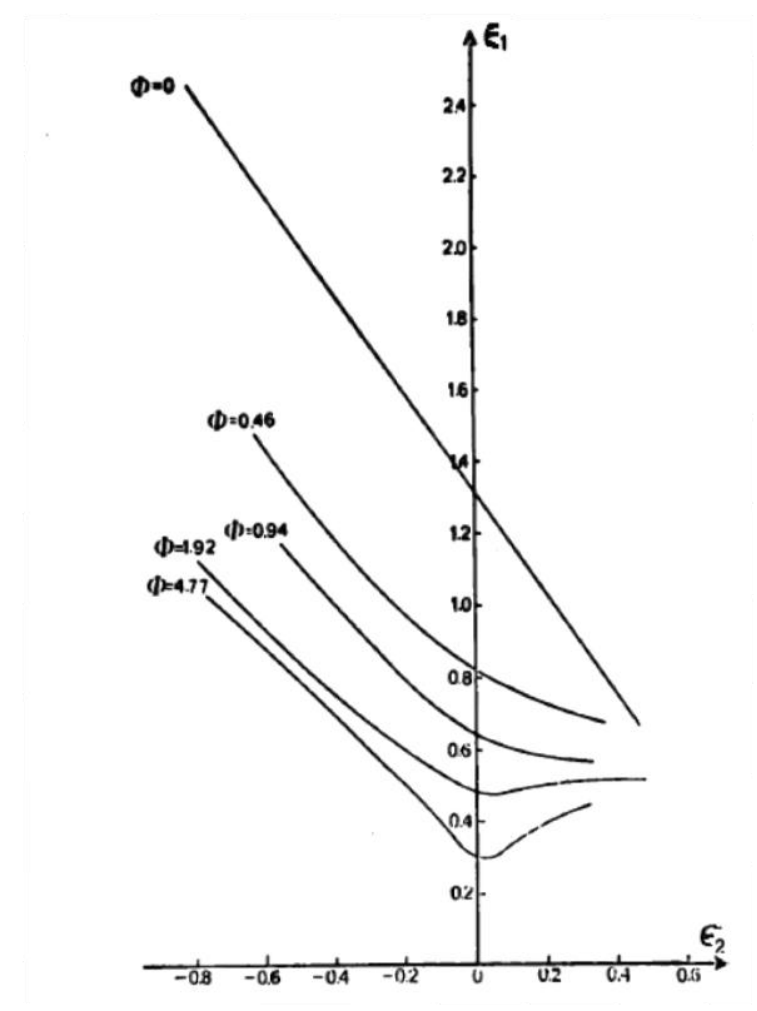

Figura 18 Demonstração da influência do diâmetro dos círculos na obtenção da curva limite de conformação (IRSID, 1975).

Com maiores espessuras se obtém maiores deformações, isso faz com que a curva se desloque para cima, tornando a chapa mais favorável ao processo de estampagem. Com o maior volume de material obrigatoriamente se torna necessário maiores deformações (ASTM E 2218). 
O coeficiente de atrito deve ser o menor possível, pois quanto menor o coeficiente, maiores serão as deformações alcançadas e a curva se posicionará mais acima, significando desta forma que o material suporta maiores reduções no processo de estampagem sem o rompimento (FOLLE et al, 2008). Os lubrificantes são submetidos a altas pressões durante o processo de estampagem, conseguindo obter eficiência até certo ponto, acima do qual o filme de óleo se rompe e as superfícies se atritam como se não houvesse esse filme. O efeito disso é que haverá uma distribuição irregular das deformações, impedindo que o material seja mais exigido durante as etapas do processo.

Folle et al (2008) estudaram a influência de dois tipos de lubrificantes diferentes para o levantamento da curva limite de conformação através do ensaio Nakazima modificado, observando a influência do atrito com corpos de prova entalhados e punção do tipo elipse raso, sendo esse atrito modificado por meio da utilização de óleo mineral e uma almofada de poliuretano $\quad$ (5 $\mathrm{mm}$ de espessura e $50 \mathrm{~mm}$ de diâmetro), pois o óleo em contato com as duas superfícies (amostra e punção) quando submetido a altas pressões chega no seu limite e se rompe e as superfície vão de encontro entre si, desta forma ocorre uma distribuição irregular da deformação impedindo que o material tenha uma melhor performance durante o ensaio. Os materiais analisados foram o aço inox 304N e alumínio 1100.

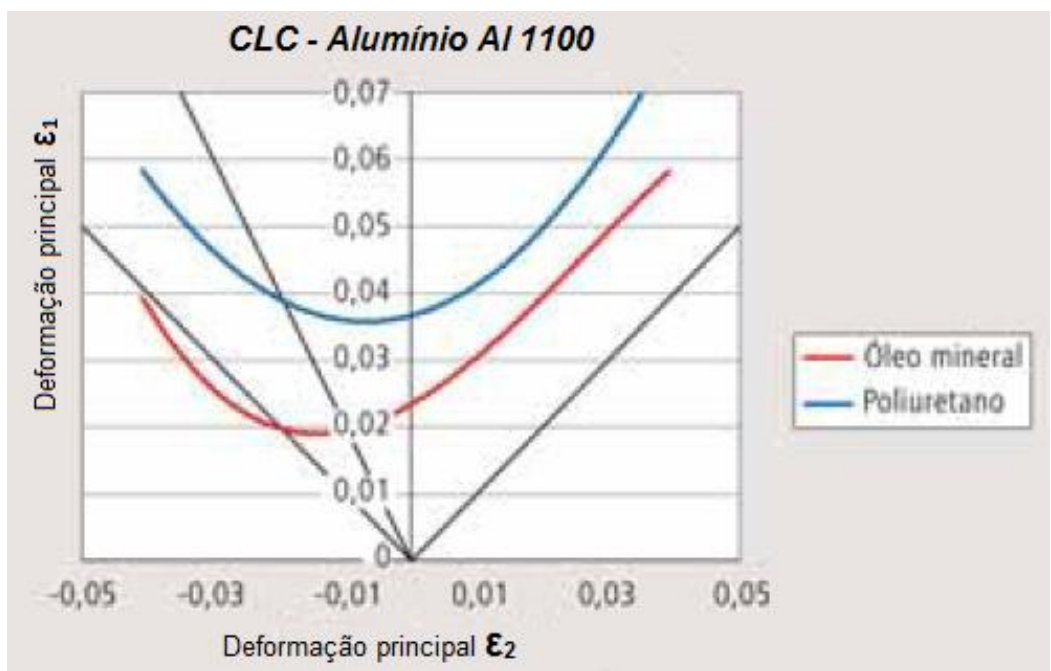

Figura 19 CLC's obtidas com lubrificantes diferentes (adaptado de FOLLE et al, 2008). 
O óleo mineral apresentou uma curva inferior, ou seja, estampagens de peças com a utilização de óleo mineral podem apresentar falhas que não serão evidenciadas com a utilização do poliuretano, portanto, o estudo do lubrificante correto é extremamente importante para o processo de estampagem e de levantamento da CLC. Essa diferença está associada ao rompimento do filme de óleo após certa pressão exercida para conformação da chapa, fazendo com que as superfícies (punção/amostra e/ou matriz/peça) entrem em contato direto e consecutivamente haverá uma distribuição inadequada das deformações, impedindo que o material seja mais exigido.

As chapas provenientes do processo de laminação apresentam propriedades mecânicas diferentes nos três sentidos principais $0^{\circ}$, 45ำ e 90ำ, sendo assim, se torna conveniente imaginar que as curvas limites de conformação sofreram alterações para cada sentido de laminação. Mandigo e Shapiro (1984) apresentam uma tabela com os resultados de limite de resistência a tração, comprovando que a direção de laminação $0^{0}$ é a que apresenta maior valor, para uma chapa de espessura 0,68 mm, com tamanho de grão de 0,040 mm na liga C26000 (Tabela 1).

Tabela 1 Resultados de Propriedades mecânicas, latão 70/30 (UNS C26000) (MANDIGO \& SHAPIRO, 1984).

\begin{tabular}{cccc}
\hline Ângulo & $\begin{array}{c}\text { Limite de Resistência } \\
\text { a Tração (MPa) }\end{array}$ & $\begin{array}{c}\text { Limite de } \\
\text { Escoamento (MPa) }\end{array}$ & $\begin{array}{c}\text { \% Alongamento } \\
\mathbf{( 5 0 , 8 0 ~} \mathbf{~ m m})\end{array}$ \\
\hline $0^{\circ}$ & 338,3 & 112,3 & 57,7 \\
\hline $45^{\circ}$ & 319,0 & 108,9 & 63,0 \\
\hline $90^{\circ}$ & 328,7 & 112,3 & 59,5 \\
\hline
\end{tabular}

Outra característica a ser analisada com cuidado é o tamanho de grão das chapas. Tamanhos de grão menores apresentam um posicionamento da curva mais acima, demonstrando maior estampabilidade, pois o refino de grão aumenta a quantidade de grãos presentes no material e a área dos contornos também e consecutivamente aumenta o número de barreiras durante o processo de conformação restringindo ainda mais o escorregamento dos átomos promovido pela tensão aplicada. A tensão requerida será superior aumentando desta forma o limite 
de resistência mecânica do material e a ductilidade, por diminuir a velocidade de encruamento durante a deformação (FOLLE et al, 2008); (SOUZA, 1982).

O grau de encruamento é avaliado através do $n$, quanto maior $n$ significa que o material é mais propício ao processo de conformação. Melander (1982) demonstra graficamente na Figura 20 que para o material Tough Pitch Copper (liga C11000), o aumento de n eleva a curva limite de conformação, comprovando o acréscimo de n e a estampabilidade da liga.

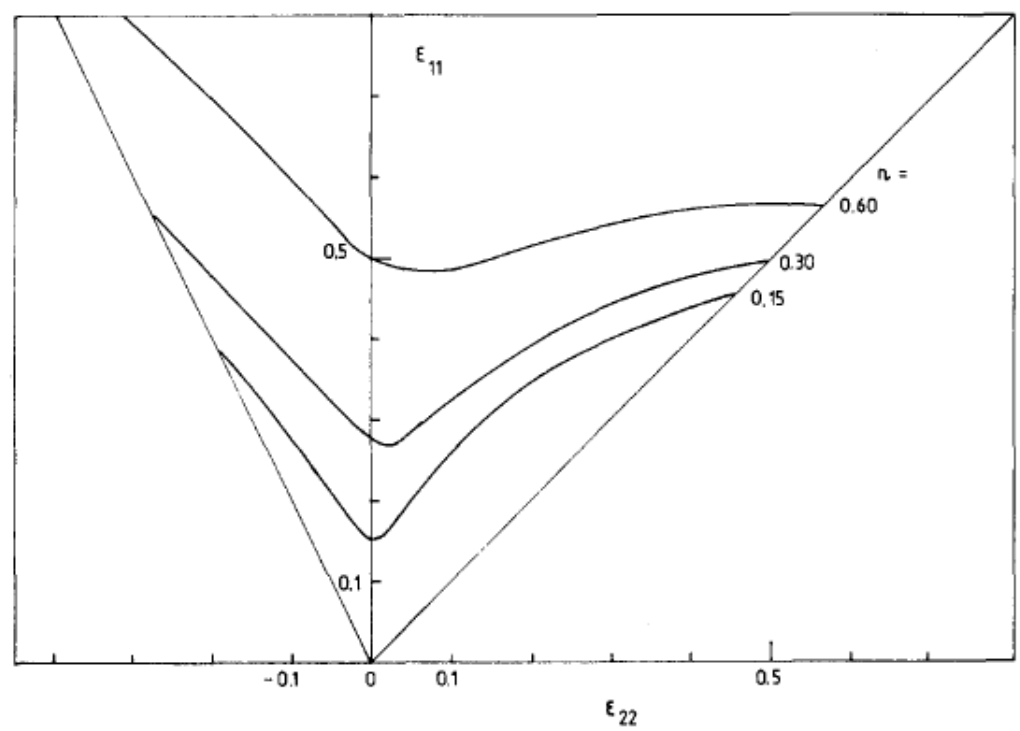

Figura 20 Curva limite de conformação do cobre UNS C11000, demonstração do aumento de n e da curva limite de conformação, evidenciando que quanto maior o valor de $\mathbf{n}$ maior é a estampabilidade da liga (MELANDER, 1982).

Hosford e Ducan (1999) descrevem que o coeficiente de encruamento ou expoente de encruamento (n) é aproximadamente igual à deformação plana obtida na curva limite de conformação. Plaut (2003) descreve que na deformação no estado plano $\left(\varepsilon_{2}=0\right.$ ou $\left.\mathrm{CLC}_{0}\right)$ o valor de $\varepsilon_{1}$ é igual ao valor do $\mathrm{n}$. Em ambos os casos não se especificou em quais condições estas afirmações podem ocorrer.

\subsection{Curva limite de conformação raiz $\left(\mathrm{CLC}_{0}\right)$}

O ponto mais importante da curva limite de conformação é conhecido como $\mathrm{CLC}_{0}$ e é denominado como a raiz da curva limite de conformação, sendo posicionado no caminho da deformação planar no ponto de menor deformação $(x)$ igual à zero $\left(\varepsilon_{2}=0\right)$, é a mínima deformação posicionada na curva limite de 
conformação para o eixo de maior deformação (y), qualquer deformação alcançada abaixo deste valor no processo de estampagem, garante que a peça fabricada não sofrerá um colapso (Figura 21), seja ele em qualquer caminho de deformação e principalmente na deformação planar.

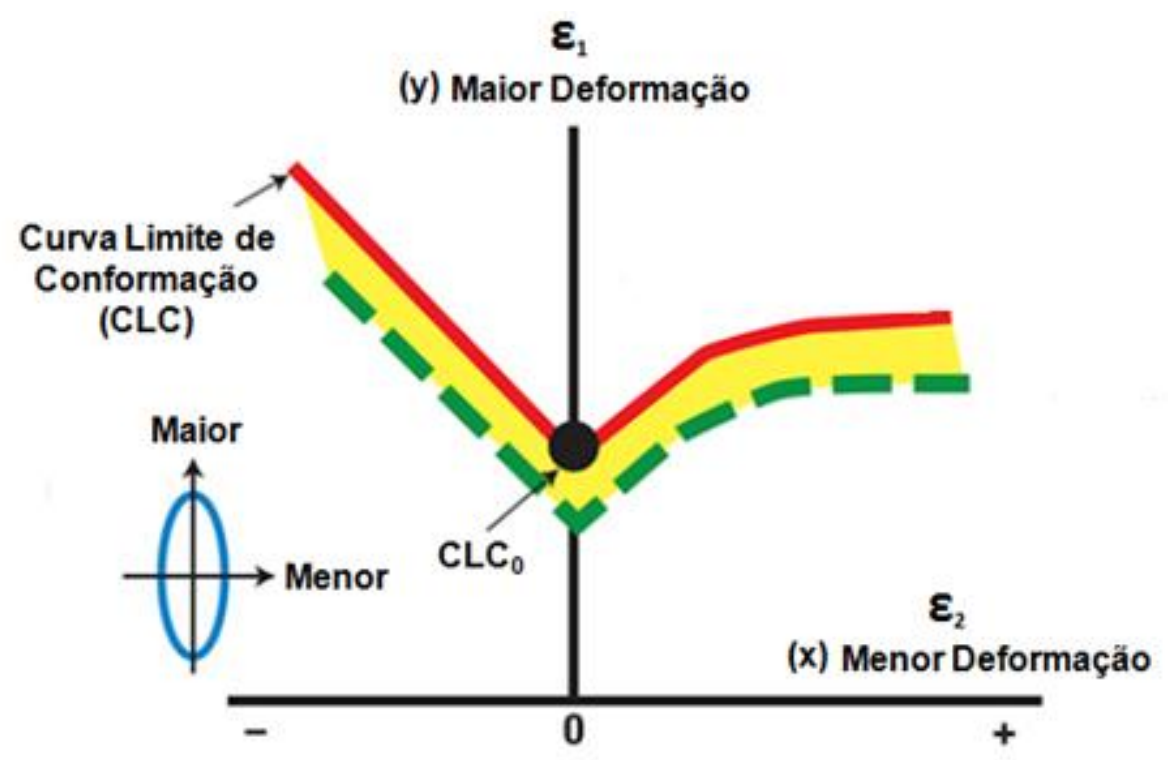

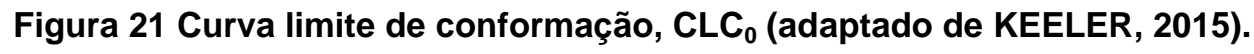

Plaut (2003), Ayres, Brazier e Sajewski (1979), Narasimhan e Wagoner (1991) descrevem que de 80 a $85 \%$ das falhas que ocorrem na fabricação de peças produzidas pela indústria automobilística são pertinentes ao caminho de deformação planar e consecutivamente ao posicionamento da $\mathrm{CLC}_{0}$, com a menor deformação $\left(\varepsilon_{2}\right)$ variando entre $\pm 2 \%$, o que caracteriza a deformação planar.

Wagoner (1980) publicou um artigo sobre a análise e medição da deformação planar em alumínio 2036 - T4 com corpos de prova possuindo diferentes geometrias. Um dos seus objetivos, foi avaliar a influência do ângulo, raio e abertura horizontal do entalhe nos corpos de prova na concentração de tensão e consecutivamente sua influência na obtenção da deformação planar. Os corpos de prova de A a F apresentaram um rompimento semelhante, obtendo-se deformações no centro dos corpos de prova de 0,09 a 0,11 a 75 a 80 \% da largura do corpo de prova, já no tipo G foi possível obter deformações de 0,08 a 0,10 a 90\% da largura do corpo de prova (Figura 22). O corpo de prova tipo $\mathrm{H}$ resultado do modelamento efetuado em elementos finitos resultou em uma deformação central de 0,14 a 0,18 em 80\% da largura do corpo de prova. 


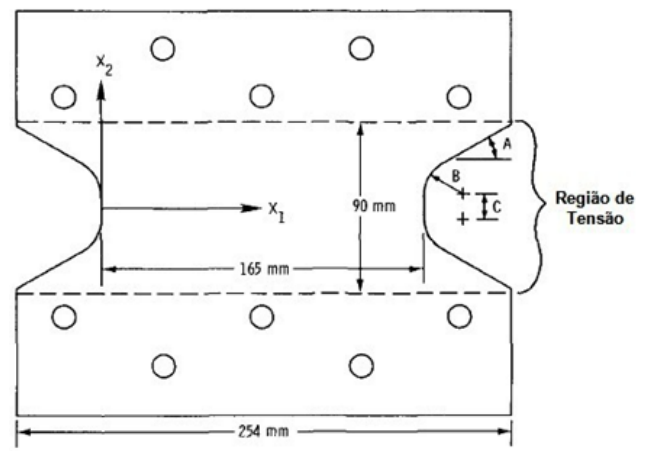

\begin{tabular}{cccc} 
Corpos de prova & $A, \mathrm{deg}$ & $B, \mathrm{~mm}$ & $C, \mathrm{~mm}$ \\
\hline$A$ & 0 & 19.1 & 12.7 \\
$B$ & 45 & 19.1 & 12.7 \\
$C$ & 30 & 12.7 & 12.7 \\
$D$ & 45 & 12.7 & 12.7 \\
$E$ & 30 & 19.1 & 12.7 \\
$F$ & 45 & 25.4 & 0.0 \\
$G$ & 0 & 12.7 & 12.7 \\
$H^{*}$ & - & 68.4 & 0.0
\end{tabular}

Figura 22 Corpo de prova para obtenção da deformação planar e variações dimensionais de A a H para as cotas A, B e C de diferentes corpos de provas (adaptado de WAGONER, 1980).

Um ano mais tarde Wagoner (1981) realizou o estudo com dois diferentes corpos de prova para a obtenção da deformação planar de aços. Um corpo de prova intitulado como "B" e outro "H" (Figuras 22 e 23), objetivou-se a comparação da deformação planar versus o coeficiente de encruamento dos materiais, pois dependendo da composição química do aço é possível correlacionar o coeficiente de encruamento com a deformação planar obtida, através de uma equação $\mathrm{FLC}_{0}=$ $(23,3+360 \times t) \times n / 0,21$ proposta por Keeler (2015), onde t é a espessura em polegadas, $n$ o coeficiente de encruamento do material.

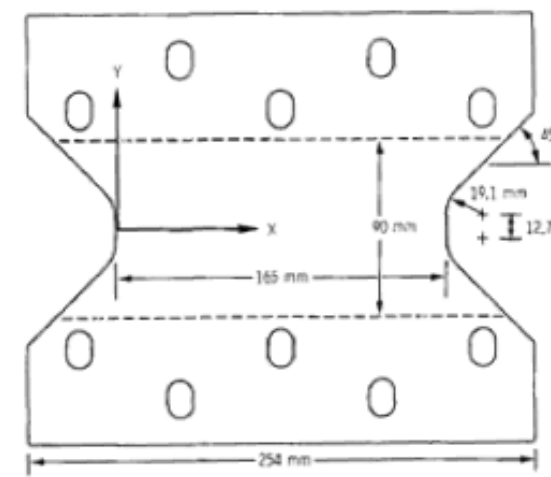

Corpo de prova tipo "B"

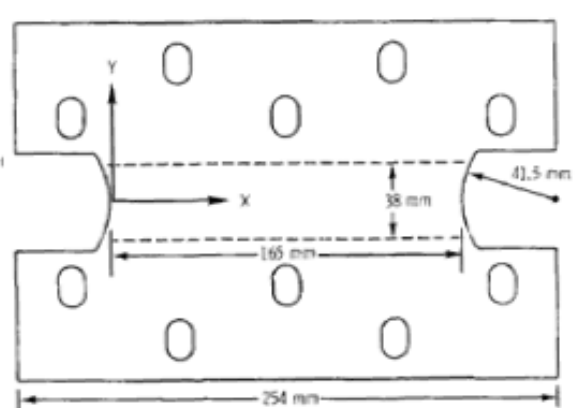

Corpo de prova tipo "H"

Figura 23 Corpos de prova para a comparação da deformação planar x coeficiente de encruamento (adaptado de WAGONER, 1981).

Björklund e Nilsson (2014) estudaram a deformação planar no aço dual-phase com corpo de prova de geometrias bem inferiores as geometrias apresentadas por Wagoner (Figura 24). O objetivo do estudo foi verificar os tipos de falhas ocorridas 
em corpos de prova de deformação planar e de ensaio Nakazima, concluindo que para o caminho de deformação planar, ocorre certa instabilidade na deformação em decorrência do aumento da velocidade antes da ocorrência da fratura do corpo de prova, estando esse aumento de velocidade diretamente relacionado ao tipo de material ensaiado e sua estrutura.

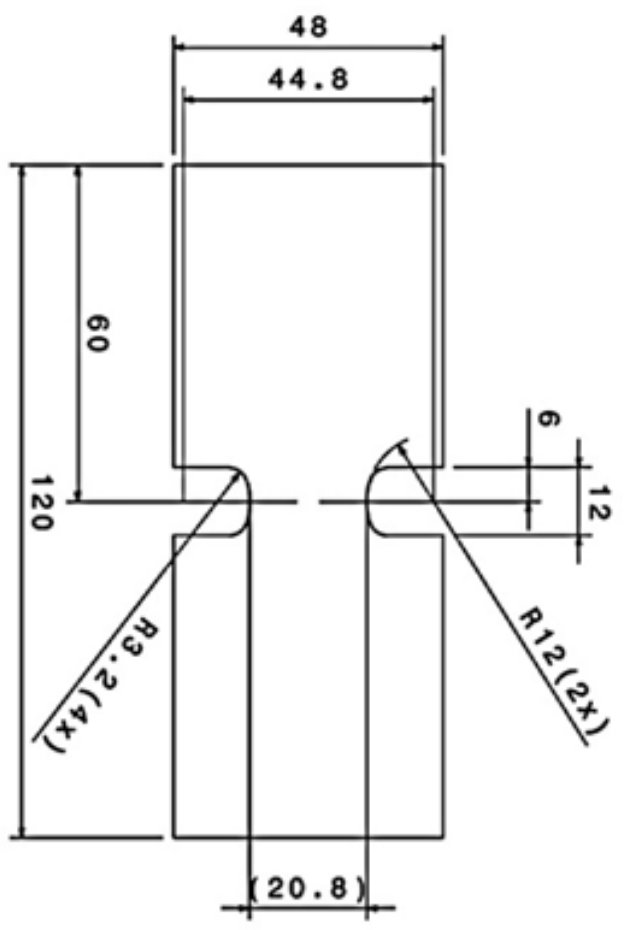

Figura 24 Corpo de prova para ensaio de determinação da deformação planar (BJÖRKLUND e NILSSON, 2014).

Xavier e Plaut (2012) avaliaram a determinação da CLC $_{0}$ através da deformação planar obtida em corpos de prova similares aos apresentados por Wagoner (Figura 25), esses resultados foram comparados com os obtidos em ensaio Nakazima para os aços IF (livre de intersticiais) e o aço SAE 1050 coalescido, concluindo que o ensaio realizado no plano não sofre a influência da geometria do punção e consecutivamente do atrito entre o punção e o material a ser ensaiado, desta forma apresenta um valor de deformação planar inferior ao apresentado pelo ensaio Nakazima, legitimando a conclusão apresentada por Schwindt et al (2015), cujo estudo realizado em ensaio da CLC no plano (ensaio de tração uniaxial) e através do ensaio de Nakazima reduzido em 60\%, também apresentou resultados divergentes para deformação planar obtida nos ensaios. 


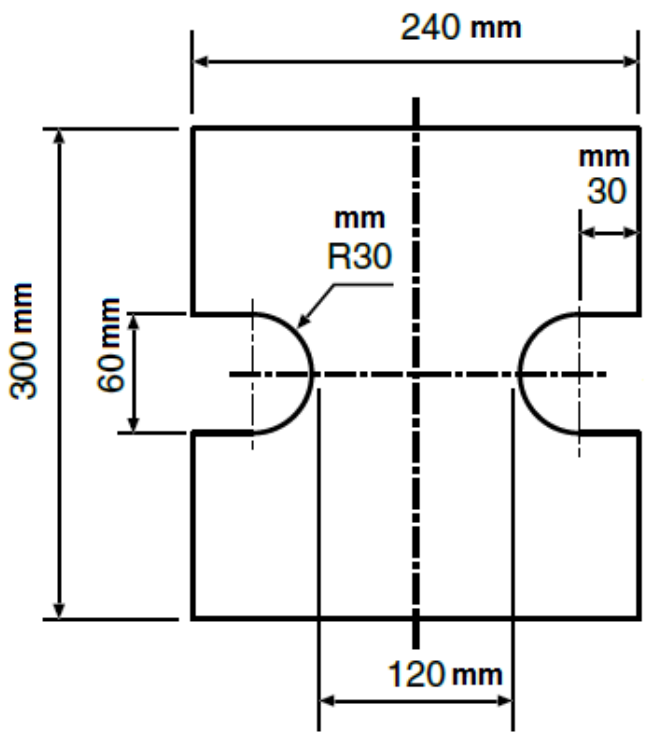

Figura 25 Corpo de prova para ensaio de determinação da deformação planar (adaptado de XAVIER e PLAUT, 2012).

3.8 Curva limite de conformação para cobre e seus ligas

Mandigo e Shapiro (1984) realizaram ensaios para levantamento das curvas limites de conformação da liga C26000. Amostras com espessura 0,68 mm e tamanho de grão de $0,040 \mathrm{~mm}$, foram ensaiadas utilizando a metodologia proposta por Marciniak obtendo desta forma a curva (a) demonstrada na Figura 26, à curva (b) demonstra um latão com espessura $0,52 \mathrm{~mm}$ na têmpera duro e diferentes pontos demonstrando o dobramento em $180^{\circ}$ e $90^{\circ}$ no sentido "badway" (sentido ruim para o dobramento) e "goodway" (sentido ideal para o dobramento), essa liga e têmpera é utilizada para fabricação de conectores elétricos, cujo dobramento é muito importante no processo de fabricação deste tipo de peça e o diagrama da Figura 26 (b) ajuda na prevenção de possíveis falhas na produção destes conectores. 


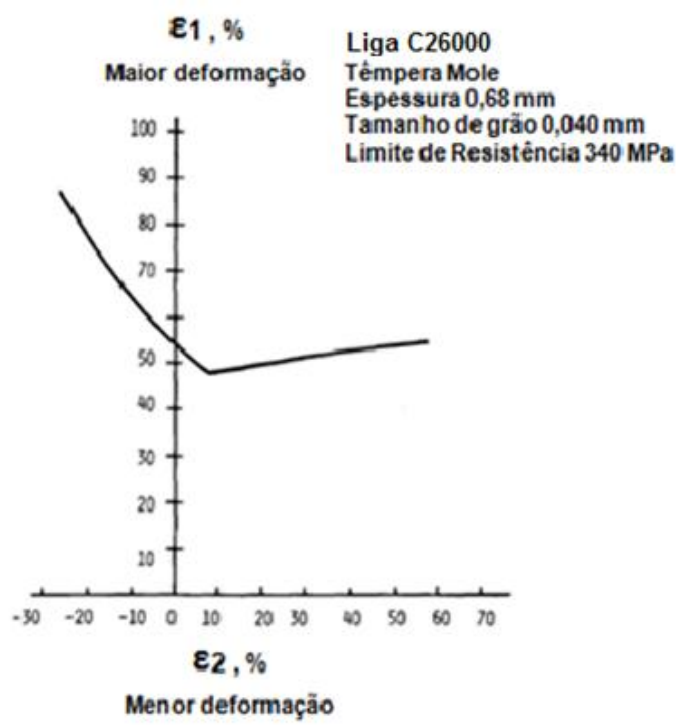

(a)

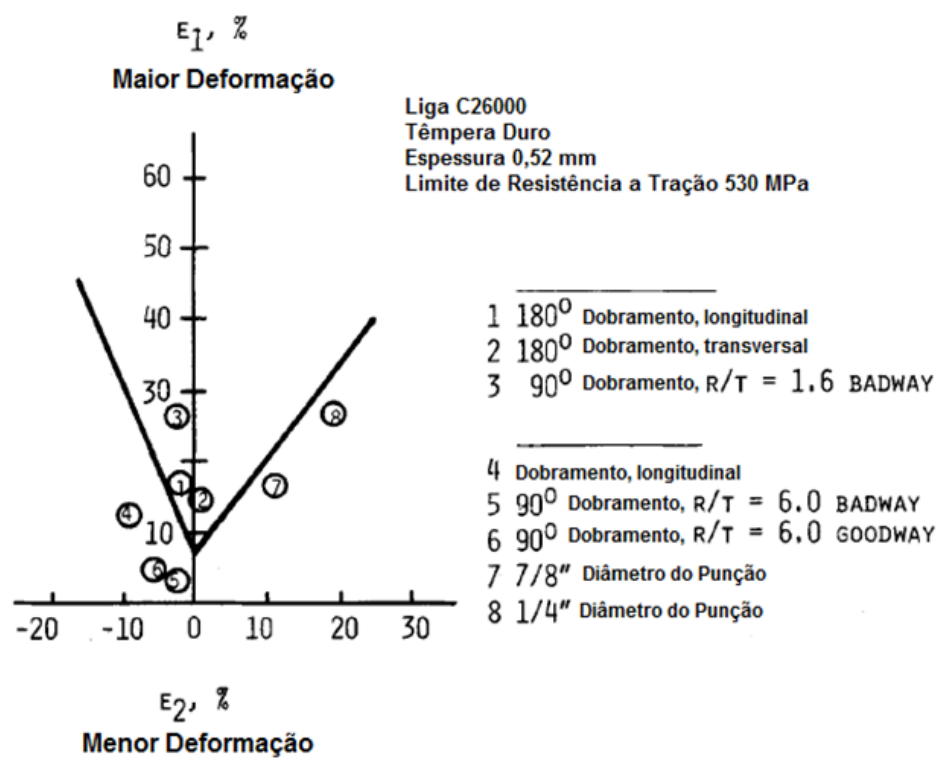

(b)

Figura 26 Curva limite de conformação da liga C26000 obtida através do ensaio Marciniak (adaptado de MANDIGO; SHAPIRO, 1984).

A norma ASTM E 2218 demonstra uma curva limite de conformação para o latão 70:30 na espessura 1,140 mm (Figura 27) e limite de resistência a tração de $349 \mathrm{MPa}$, próximo ao apresentado pelo material ensaiado por Mandigo e Shapiro (1984) (340 MPa), a curva demonstrada pela norma apresenta-se similaridade apesar dos $40 \%$ de diferença entre as espessuras, vale ressaltar que a norma não especifica a forma de obtenção da curva limite de conformação. Vimos anteriormente que é possível se obter a CLC de diferentes formas e que o número 
de variáveis é extremamente grande, portanto, essa diferença de $40 \%$ na espessura entre os materiais ensaiados pode ser mascarada pela metodologia utilizada na obtenção da curva limite de conformação entre a norma e Mandigo e Shapiro (1984).

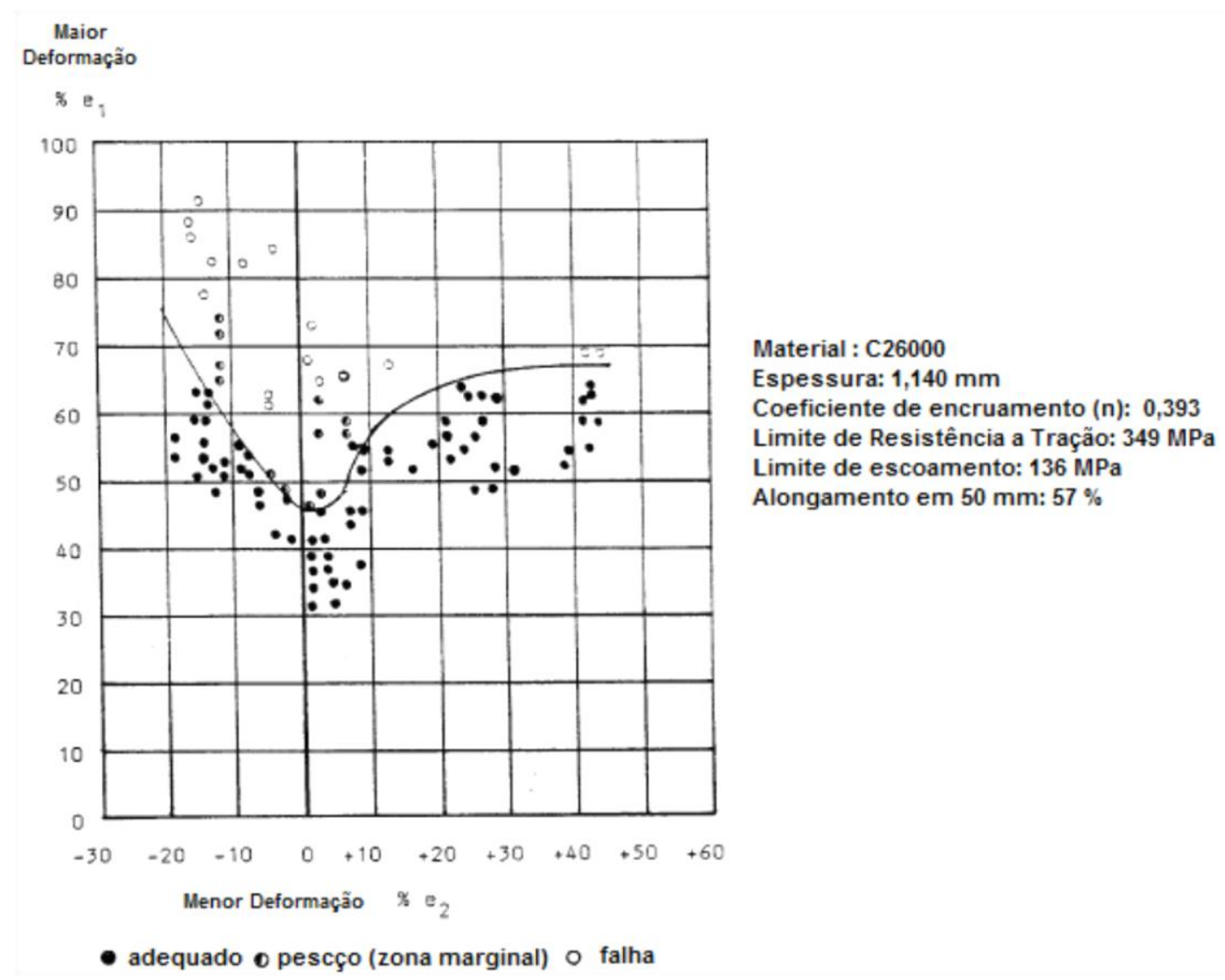

Figura 27 Curva limite de conformação exposta na norma ASTM E 2218, latão 70:30. (adaptado de ASTM E2218, 2015).

Melander (1982) realizou o levantamento da curva limite de conformação para cobre e suas ligas (Figuras 28 e 29), através de corpos de prova com a seguinte dimensão, comprimento de $200 \mathrm{~mm}$, largura de $68 \mathrm{~mm}$ e entalhes com raios de 10, 20, 30 e 66 mm. Estampou círculos com 2 mm de diâmetro não especificando o método utilizado para a estampagem dos círculos, ensaiou as amostras em uma prensa hidráulica, efetuou a medição dos círculos deformados nas regiões adjacentes as trincas e calculou as deformações, com a obtenção dos valores das ordenadas $\varepsilon_{11}$ correspondentes a deformação principal e maior no plano da chapa e os valores das abscissas $\varepsilon_{22}$ correspondentes a menor deformação perpendicular ao 
plano da chapa, podendo ser evidenciado a diferença apresentada entre as ligas C11000 e C10200 com um aumento de \pm 16\% na deformação planar, sendo as ligas diferenciadas basicamente pelo teor de oxigênio contido na liga 400 ppm máximo para liga C11000 contra 10 ppm máximo para liga C10200, sendo essa diferença decorrente da formação de "voids" durante as etapas de laminação a quente e a frio através da fratura dos óxidos internos contidos no material.

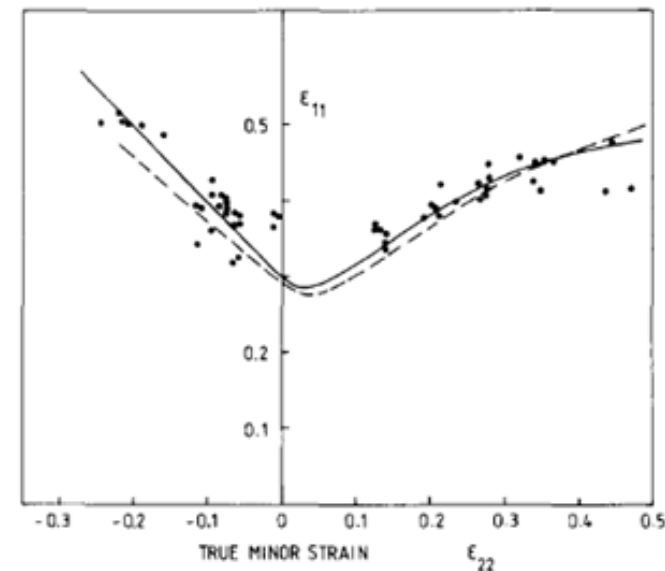

(a)

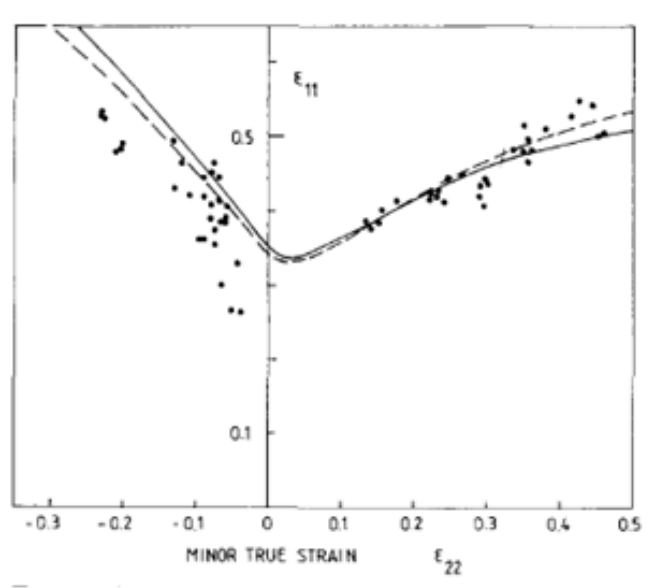

(b)

Figura 28 Curva limite de conformação (a) Cobre tough pitch copper (UNS C11000) e (b) Cobre oxygen-free (UNS C10200) (MELANDER, 1982).

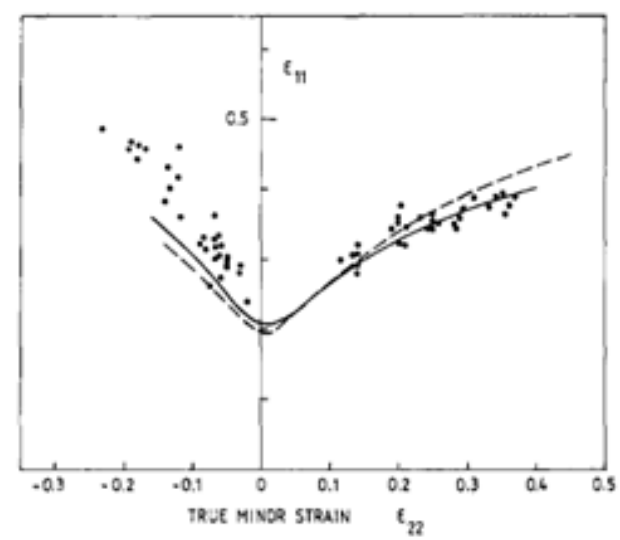

(a)

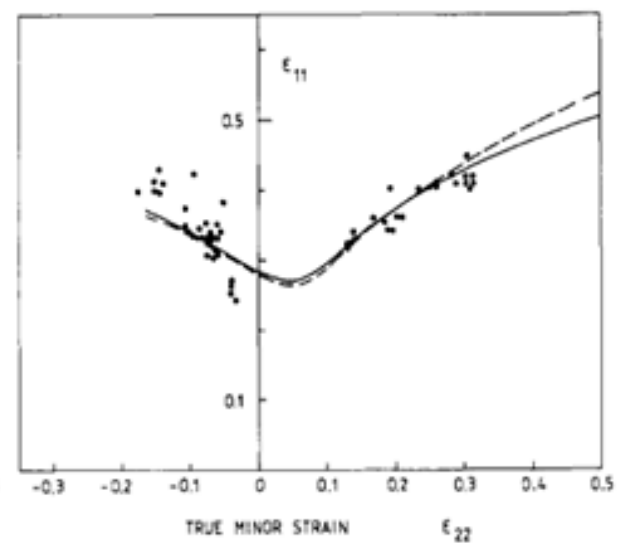

(b)

Figura 29 Curva limite de conformação (a) Latão e (b) Cobre - Níquel (MELANDER, 1982).

Tseng, Hung e Huang (2010) publicaram um artigo sobre "clad" de Alumínio/Cobre. As ligas utilizadas para elaboração das chapas foram A1050 e C11000, o objetivo principal do artigo era construir a curva limite de conformação 
para esse tipo de folha e comparar com a chapa das ligas normais. A Figura 30 demonstra as chapas preparadas e seus respectivos resultados obtidos.

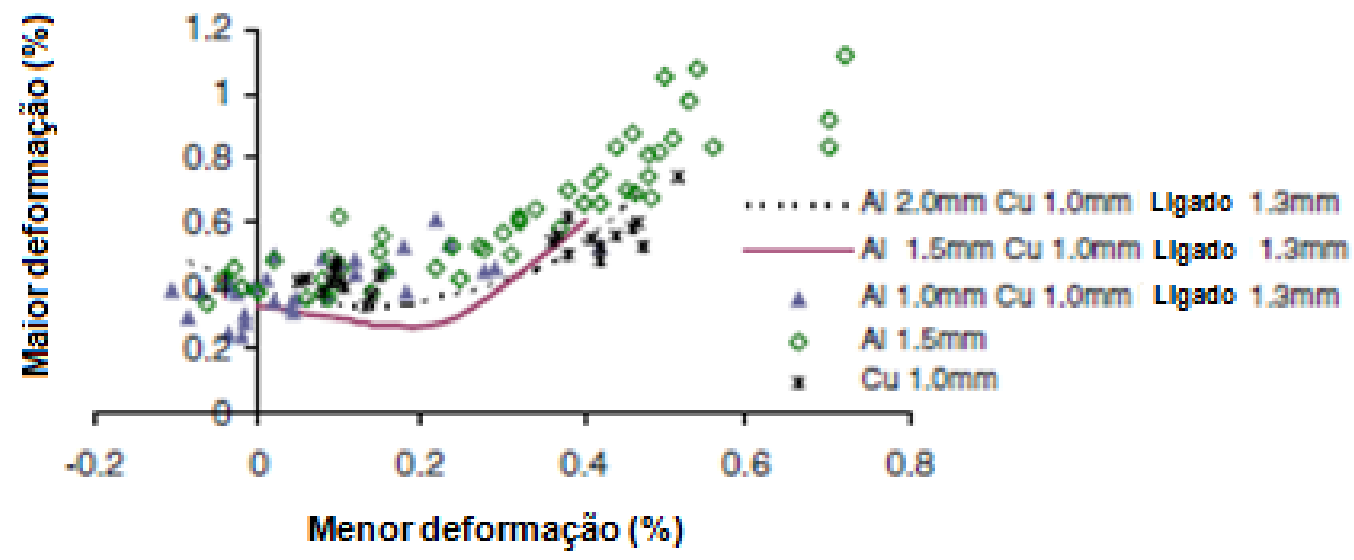

Figura 30 Curva limite de conformação, para espessura final de $1,30 \mathrm{~mm}$ do "clad", com variação da espessura inicial do alumínio e chapa de cobre "puros" (UNS C11000) (adaptado de TSENG; HUNG; HUANG, 2010).

A estampabilidade dos materiais puros, ou seja, somente as chapas de alumínio ou de cobre, apresentaram valores superiores aos encontrados nos "clads", pois as folhas são afetadas pela tensão residual proveniente do processo de laminação a frio. Apresentando assim uma estampabilidade inferior, curvas mais baixas como as demonstradas na Figura 30. A previsão de fratura dos "clads" pelo software demonstrou ser muito precisa devido ao auxílio das curvas limites de conformação obtidas.

Davis (2001) demonstra inúmeras curvas limites de conformação para cobre e suas ligas com diferentes particularidades, como a influência da têmpera na obtenção das curvas. Para a liga de latão 70:30 expõe a curva em três condições diferentes a primeira possui espessura de $0,64 \mathrm{~mm}$ e está no seu estado recozido (têmpera) com tamanho de grão de $25 \mu \mathrm{m}$ e limite de resistência a tração de $345 \mathrm{MPa}$, a segunda é considerada meio-dura (têmpera) com espessura de 0,69 mm, limite de resistência a tração de $407 \mathrm{MPa}$ e alongamento de $28 \%$, a terceiro e última possui espessura de $0,51 \mathrm{~mm}$ e é considerada dura (têmpera) com limite de resistência a tração de $531 \mathrm{MPa}$. 


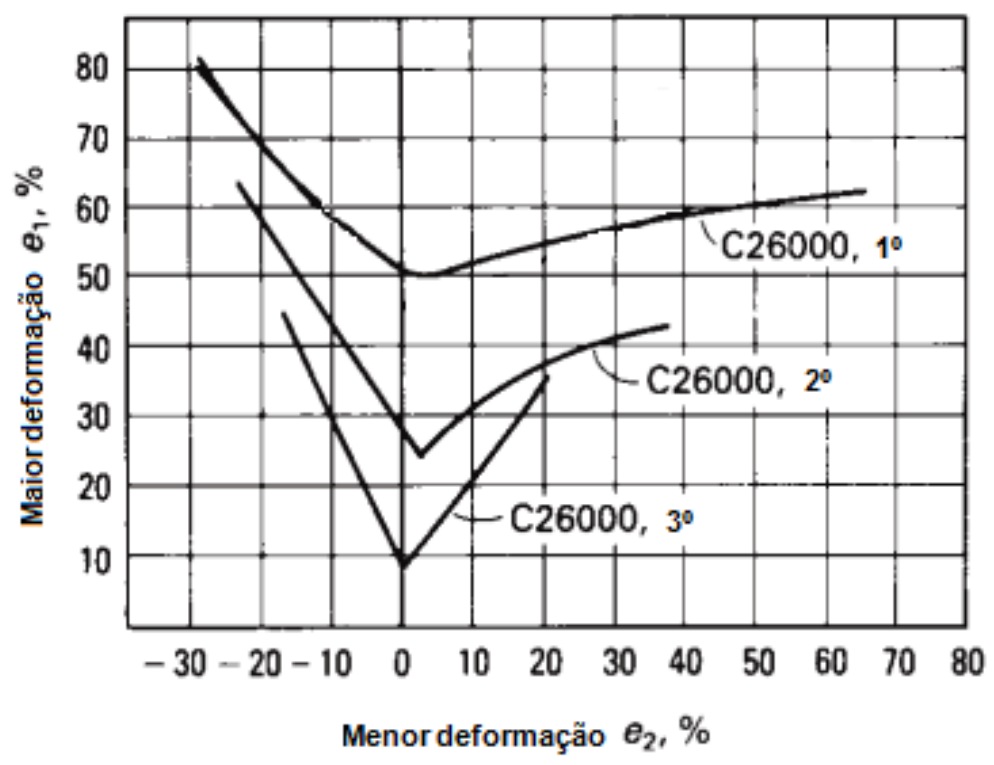

Figura 31 Curva limite de conformação latão 70:30 em diferentes condições (têmperas) (adaptado de DAVIS, 2001).

Levando em consideração apenas o limite de resistência à tração (têmpera), evidenciamos na Figura 31 que o aumento da resistência mecânica causa uma queda nas deformações obtidas pelas curvas, diminuindo consideravelmente a estampabilidade das chapas ensaiadas. A deformação em seu estado plano baixouse em torno de $80 \%$, entre a primeira e terceira amostra, em quanto que o limite de resistência à tração aumentou-se em torno de 35\%, demonstrando maior influência na deformação do que na resistência mecânica. Esta afirmação só seria possível se os materiais apresentassem a mesma espessura, visto que a espessura exerce grande influência na obtenção das curvas.

Em Copper and Copper Alloys, Davis (2001) demonstra inúmeras curvas limites de conformação para cobre e suas ligas. Ligas de cobre puro, cobre + zinco, cobre + estanho e cobre + níquel, evidenciando particularidades em função da composição química e das propriedades mecânicas em que se encontra os materiais, porém, não se especifica a forma que as curvas foram obtidas, que tipo de ensaio foi feito para se obter os resultados, conforme visto anteriormente os resultados possuem grande influência da forma de determinação das curvas. 

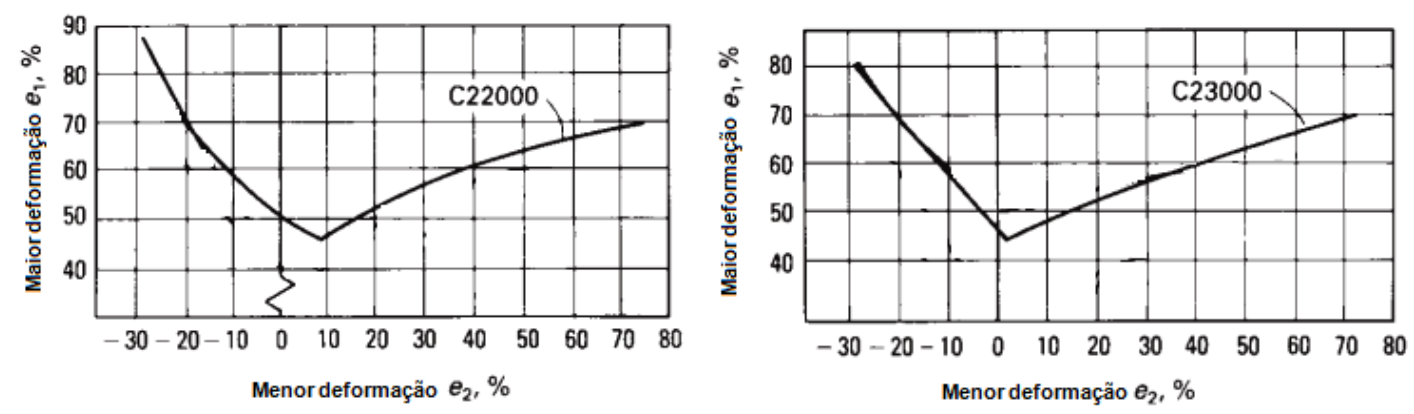

Figura 32 Curvas limite de conformação do Tomback UNS C22000 e UNS C23000 (adaptado de DAVIS, 2001).

A Figura número 32 (DAVIS, 2001) demonstra as curvas do latão UNS C22000 com 10\% de zinco e da liga UNS C23000 com 15\% de zinco, ambas na mesma espessura, porém, com tamanho de grão diferente em torno de $29 \%$, podendo ser evidenciado que os $5 \%$ de zinco a mais na liga e os $29 \%$ de diferença no tamanho de grão não exerceram influência significativa na obtenção das curvas limites de conformação, apenas o deslocamento da menor deformação para o lado direito da curva da liga UNS C22000, desde que a obtenção das curvas foi efetuada da mesma forma.

A deformação plana CLC $_{0}$ para a liga UNS C22000 é de aproximadamente $\varepsilon_{1}$ $\cong 50 \%$, para a liga UNS C23000 é $\varepsilon_{1} \cong 48 \%$, diferenciando-se em $4 \%$, o que pode ser considerado como uma diferença baixa, haja visto que são numerosas as variáveis que influenciam a obtenção das curvas.

Stachowicz (1989) realizou um estudo sobre a verificação da influência do tamanho de grão na estampagem de latão, alumínio e aço, através da elaboração da curva limite de conformação no ensaio de Marciniak e pelo levantamento dos coeficientes de encruamento, em ensaios de tração uniaxial e ensaio de "bulge test" (biaxial). O latão estudado foi à liga classificada como UNS C23000 com espessura de $1,00 \mathrm{~mm}$ em quatro condições distintas, ou seja, recozidas a $650^{\circ} \mathrm{C}$ por períodos de 1, 2, 4 e 8 horas, obtendo-se tamanhos de grãos e coeficientes de encruamento médios $\left(0,45\right.$ e $\left.90^{\circ}\right)$ no ensaio de tração uniaxial e no teste de "bulge test" (biaxial), conforme expostos na Figura 33.

As principais conclusões de Stachowicz (1989) é que os caminhos de deformação da tensão uniaxial não apresentaram alterações significativas entre as 
amostras analisadas, demonstrando similaridade em todos os casos (Figura 33), já a deformação planar diminui com o aumento do tamanho de grão. Comparando a amostra de número um com a amostra de número dois, um aumento de $30,5 \%$ no tamanho de grão, diminui a deformação planar em torno de 16,67\%. Conclui-se ainda que quanto maior o tamanho de grão maior é o coeficiente de encruamento obtido e menor é o posicionamento da curva limite de conformação, ou seja, menor seria a estampagem da liga estudada, contrariando a teoria exposta por inúmeros pesquisadores. Melander (1982) demonstra graficamente para o cobre puro, liga UNS C11000 o aumento da curva limite de conformação em função do aumento de n (vide item 3.6 deste trabalho). Plaut (2003), Banabic (2010), Hosford e Caddell (2007) afirmam que quanto maior o coeficiente de encruamento $n$ maior será as deformações obtidas nas curvas limites de conformação.
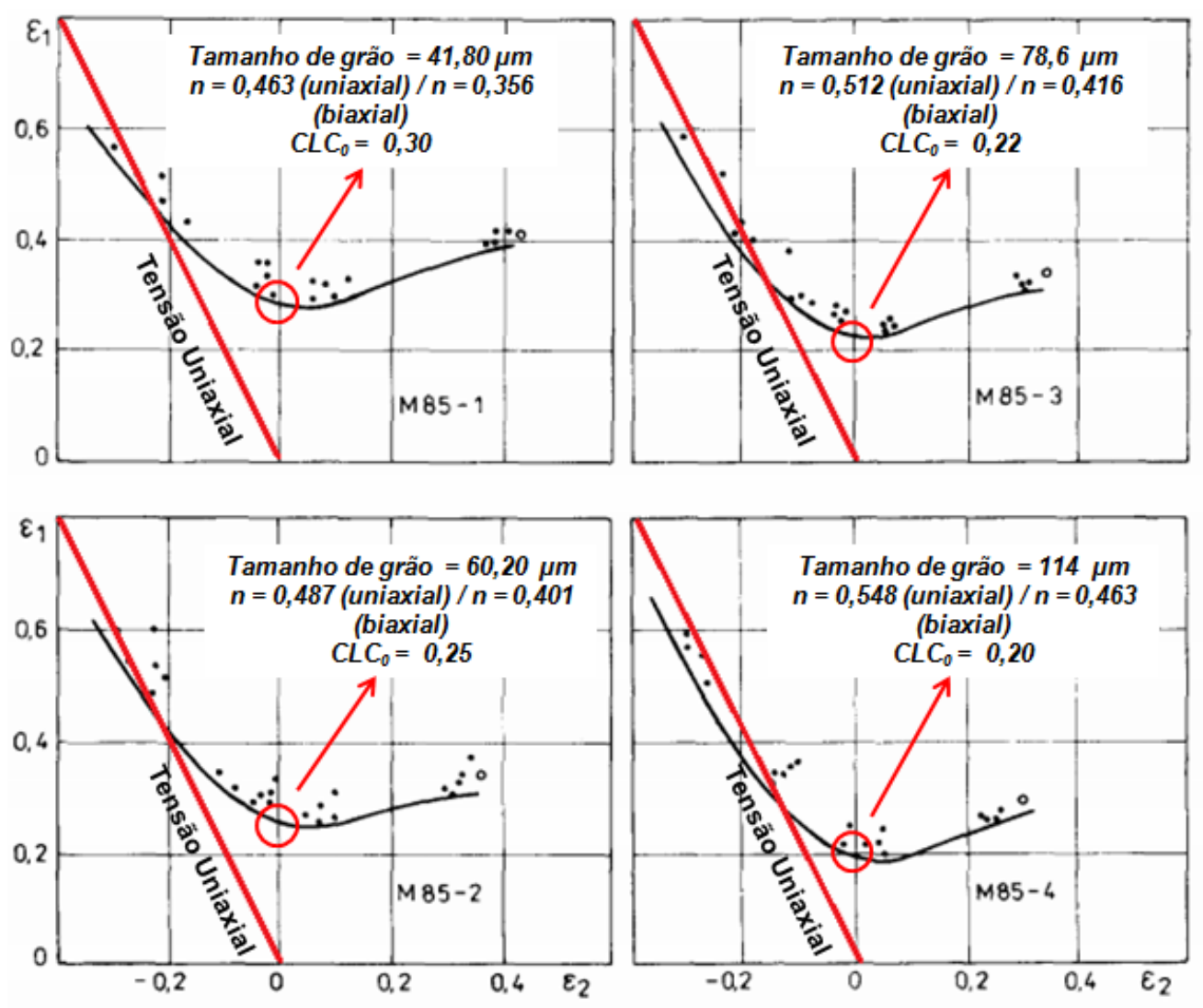

Figura 33 Curva limite de conformação da liga UNS C23000 obtida pelo ensaio de Marciniak para vários tamanhos de grão, espessura 1,00 mm (adaptado de STACHOWICZ, 1989). 
3.9 Levantamento da curva limite de conformação pelo ensaio de tração uniaxial

Holmberg, Enquist e Thilderkvist (2003), realizaram um estudo do levantamento da curva limite de conformação através de ensaios de tração uniaxial para dois aços, identificados como aço de baixa resistência e de alta resistência, obtendo resultados com pequena dispersão e é claro sem a presença do atrito, visto que os ensaios são realizados no plano da chapa. O procedimento de teste pode ser utilizado na determinação completa do lado esquerdo da curva limite de conformação, porém, as geometrias das amostras são essenciais para se obter êxito nos resultados, sendo assim o trabalho foi conduzido de duas formas; através da utilização do software ABAQUS/Standard visando obter a geometria correta dos corpos de prova e a realização dos ensaios físicos.

Os autores afirmam que não existe um padrão único para determinação das curvas limites de conformação. O conceito das CLC's pressupõe uma série de limitações e incertezas, geralmente se imagina que os caminhos são lineares para a deformação, isto é, o modo de deformação mantém-se constante durante todo o processo de conformação, porém, na maioria dos casos práticos essa condição não ocorre, devido às características dos materiais utilizados. Outros inconvenientes são resultados experimentais influenciados pelas condições de atrito durante os ensaios, alterados por lubrificantes específicos e acabamento superficial das ferramentas utilizadas nos testes e do próprio material, existindo ainda um pequeno desvio da deformação linear devido ao dobramento do corpo de prova ocorrido durante o processo de conformação.

O teste realizado através da tração uniaxial é rápido e simples, sem a necessidade de equipamentos específicos, apenas uma máquina de ensaio de tração, obtendo uma baixa dispersão dos resultados e não existindo a influência do atrito sobre os seus resultados (BANABIC, 2010); (HOLMBERG; ENQUIST; THILDERKVIST, 2003).

As fixações dos corpos de prova nas garras durante os ensaios devem ser efetuadas da melhor forma possível, pois caso contrário, a fratura não ocorrerá na 
região central dos corpos de prova, onde as condições de deformação plana se aplicam e devem ser objetivadas (HOLMBERG; ENQUIST; THILDERKVIST, 2003).

As larguras dos corpos de prova influenciam significativamente o estado de tensão. Os corpos de prova devem possuir a largura o maior possível a fim de obter uma condição tão perto quanto possível da deformação plana na região central dos corpos de prova.

O comprimento do entalhe dos corpos de prova tem uma grande influência nos resultados, devem ser os menores possíveis a fim de se obter uma condição mais próxima da deformação plana na região central dos corpos de prova.

A altura do entalhe tem uma grande influência sobre a distribuição de tensões e deformações nos corpos de prova, com uma altura do entalhe muito grande, a deformação nas bordas se tornará grande e a fratura ocorrerá nas bordas dos corpos de prova e não na região central desejada.

Ensaios de tração são utilizados na determinação do lado esquerdo completo da CLC, conforme descrito anteriormente, ao alterar a geometria dos corpos de prova, as diferentes condições da deformação são alcançadas. O lado direito da CLC não pode ser determinado por este processo (Figura 34) (HOLMBERG; ENQUIST; THILDERKVIST, 2003).
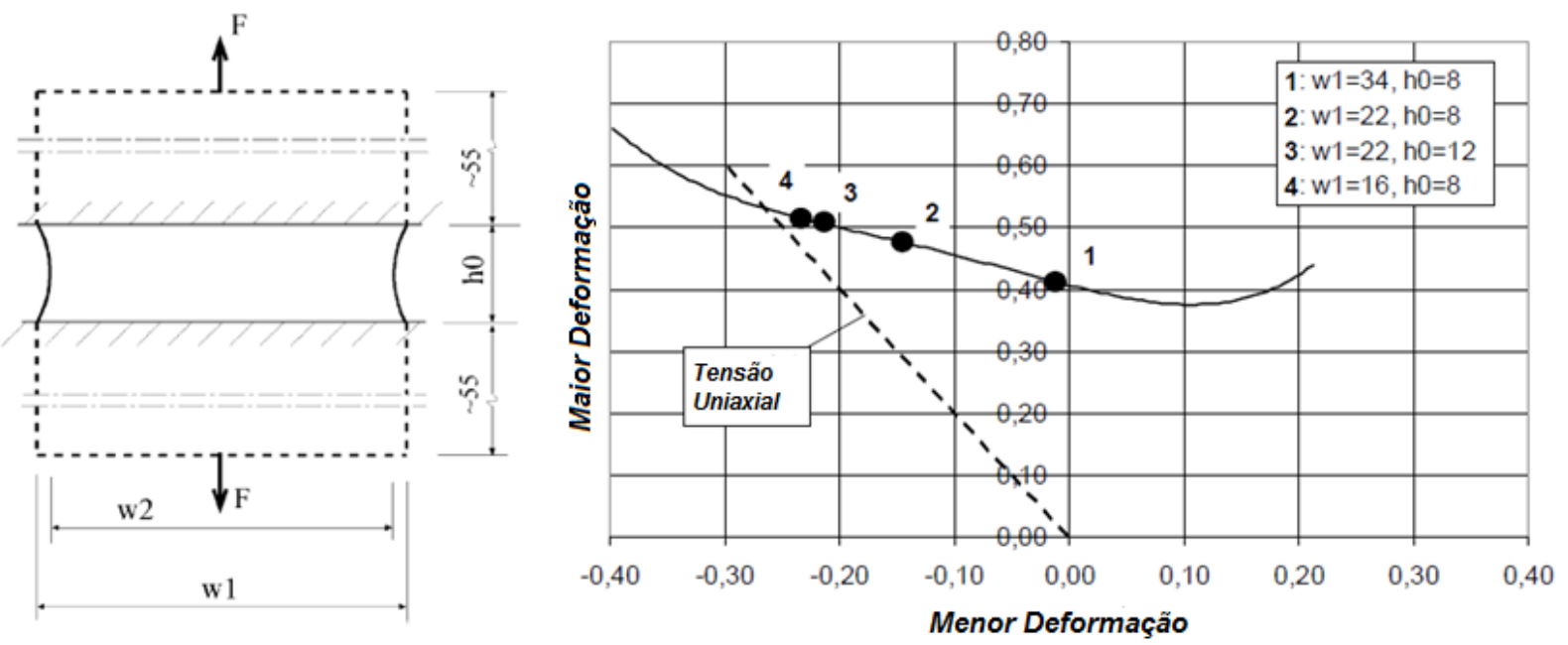

Figura 34 Corpo de prova e curva limite de conformação do aço "macio" (Mild steel) elaborada através dos ensaios de tração (adaptado de HOLMBERG; ENQUIST; THILDERKVIST, 2003). 
Dentre as conclusões expostas, este método Holmberg's permite uma rápida e fácil determinação da estampabilidade da chapa. Os resultados obtidos mostram pequena dispersão quando comparados com os métodos convencionais, pois não existe a influência do atrito e consecutivamente do lubrificante e a cota $h_{0}$ do corpo de prova exerce grande influência nos resultados obtidos. 


\section{MATERIAIS E MÉTODOS}

\subsection{Caracterização química}

A análise da composição química das bobinas fornecidas pela PARANAPANEMA S.A. provenientes do processo de fundição contínua e fundição semicontínua, foram efetuadas ainda no processo de fusão do metal. Ambas as amostras foram retiradas com uma concha do forno de fusão do tipo holding e vazadas em um molde com diâmetro de $32 \mathrm{~mm}$ e comprimento de $25 \mathrm{~mm}$, sendo desbastadas em um torno universal horizontal da marca Nardini, modelo 300 III, lixadas na lixa de grana \#320 e enxaguadas em água corrente, álcool e secadas com soprador de ar quente. Posteriormente as amostras foram então analisadas por fluorescência de raios-X, no espectrofotômetro Philips modelo PW2400. A tabela 2 demonstra o especificado pela norma ASTM e os resultados obtidos para cada processo.

Tabela 2 Composição química das amostras, determinada por fluorescência de raios-X.

\begin{tabular}{ccccccccc}
\hline \multirow{2}{*}{ Amostras } & & \multicolumn{7}{c}{ Composição química, em \% mássica } \\
\cline { 2 - 9 } & $\mathbf{C u}$ & Fe & Sn & $\mathbf{C r}$ & $\mathbf{C d}$ & $\mathbf{P b}$ & $\mathbf{B i}$ & $\mathbf{Z n}$ \\
\hline ASTM & $89,0-91,0$ & 0,05 & --- & --- & --- & 0,05 & 0,006 & Restante \\
& & máx & & & & máx & máx & \\
F.C. & 89,7200 & 0,0050 & 0,0078 & 0,0022 & 0,0011 & 0 & 0 & 10,2639 \\
F.S.C. & 89,7700 & 0,0027 & 0,0045 & 0,0071 & 0,0019 & 0 & 0 & 10,2138 \\
\hline
\end{tabular}

4.2 Processos iniciais de produção fusão e laminação a quente

Os rolos disponibilizados foram produzidos inicialmente por dois processos distintos. Uma bobina foi produzida pelo processo de fundição contínua possuindo a seguinte dimensão $13,70 \times 650 \times 45.000 \mathrm{~mm}$, sendo o metal líquido vazado continuamente em um molde de grafite com o formato da chapa a ser produzida, obtendo-se desta forma uma bobina em rolo com uma estrutura bruta de fundição, 
com peso de aproximadamente $3526 \mathrm{~kg}$. A placa proveniente do processo de fundição semicontínua, foi fabricada através do vazamento do metal líquido em um molde metálico (lingoteira) posicionado horizontalmente através da descida do molde por um pistão em um poço, resultando em uma placa com a seguinte dimensão 180X650X4.000 mm e peso de aproximadamente $4118 \mathrm{~kg}$, sendo esta placa aquecida em um forno a gás e laminada posteriormente a quente através de 13 passes com uma redução total de 92,44 \% variando a redução entre os passes de 22,20 a 9,70 \%, dando origem a uma bobina de 13,60X650X52.500 mm. Ambas as bobinas, foram então fresadas, devido aos óxidos superficiais provenientes dos processos de fundição e laminação a quente em que as bobinas foram submetidas inicialmente, a camada removida no fresamento foi de $\pm 0,60 \mathrm{~mm}$ por superfície, totalizando uma remoção de 1,20 mm entre a superfície superior e inferior (Figura 35).
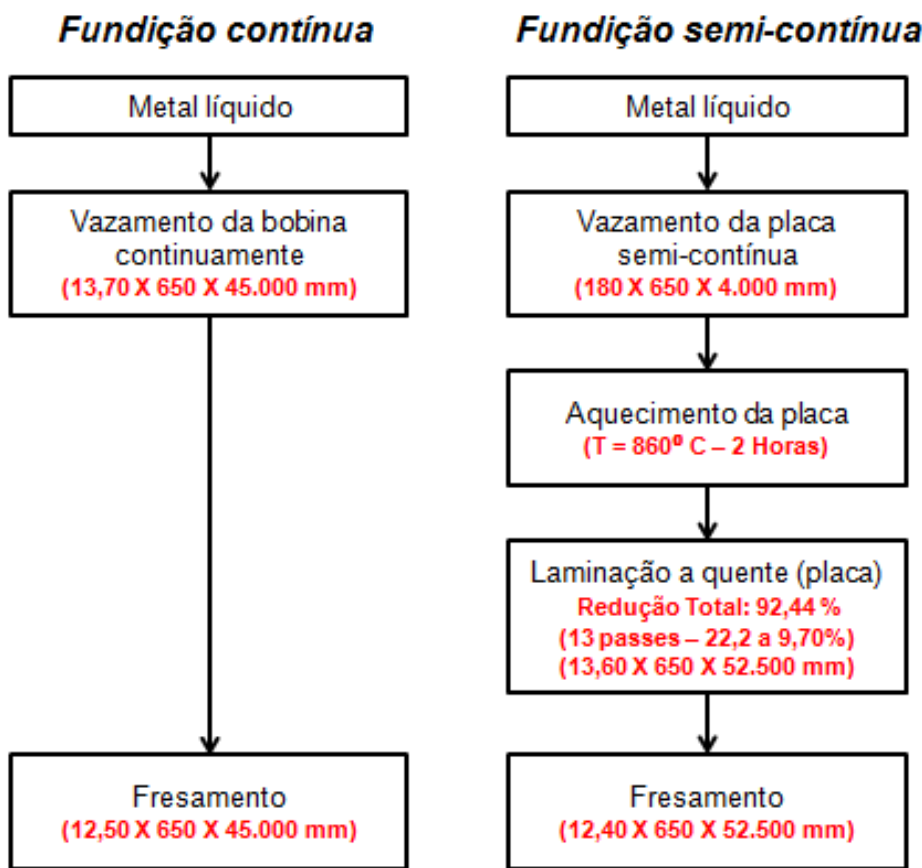

Figura 35 Fluxograma dos processos iniciais de fundição continua e fundição semicontínua.

\subsection{Ensaios de macrografia}

Duas amostras foram retiradas, sendo uma da bobina do processo F.C. de $12,50 \times 650 \times 250 \mathrm{~mm}$ e uma do processo F.S.C. de 12,40X650X280 mm cortadas na ponta externa dos rolos com uma serra de disco da marca LOMA, modelo 0344-6B, 
para os ensaios de macrografia (Figura 37 (b)). Essas amostras foram então fresadas em uma máquina operatriz da marca Atlasmaq, modelo FVA-50 big e lixadas nas lixas de grana \#180 e \#320, atacadas quimicamente com ácido clorídrico puro $(\mathrm{HCl})$ por um período de 3 minutos, objetivando avaliar macroscopicamente a diferença de estrutura entre os dois processos iniciais.

\subsection{Processos de fabricação das chapas (laminação a frio e recozimento)}

Após a fusão, laminação a quente e fresamento, os rolos foram submetidos ao processo de laminação a frio, as bobinas foram processadas da mesma forma (Figura 36), sendo aplicado na primeira etapa de produção uma redução total a frio de $\pm 85 \%$ em um laminador de desbaste do tipo Quadruo, laminou-se de 12,40 (F.S.C.) e 12,50 (F.C.) $\mathrm{mm}$ para $1,83 \mathrm{~mm}$, através de 5 passes variando gradualmente de 34 a $22 \%$ de redução de espessura entre os passes, a fase seguinte, o recozimento, foi realizado em um forno do tipo "Sino" com aquecimento a gás e capacidade de recozimento de $26.000 \mathrm{~kg}$, sendo os rolos recozidos na primeira camada e posicionados um ao lado do outro. A temperatura utilizada no recozimento intermediário foi de $530^{\circ} \mathrm{C}$, por um período total de 720 minutos. No APÊNDICE A é possível visualizar o esquema de aquecimento do forno e o mapeamento da temperatura realizada durante 0 recozimento do material intermediário. Ao término do recozimento, os rolos foram submetidos ao processo de limpeza superficial, sendo a chapa imersa em uma solução ácida contendo $13 \%$ de $\mathrm{H}_{2} \mathrm{SO}_{4}$ mais água potável e seguida do escovamento abrasivo. A laminação final foi efetuada em um laminador de acabamento também do tipo Quadruo com sistema de correção automática AGC (Automatic gage control), sendo a redução total aplicada de $40 \%$ em dois passes com reduções de 23 e 21\%, laminando de 1,83 mm para $1,10 \mathrm{~mm}$, obtendo desta forma uma variação de espessura inferior a $\pm 0,010 \mathrm{~mm}$ ao longo da largura e comprimento da chapa. O recozimento final dos rolos foi também executado em um forno tipo "Sino", com a temperatura de $450^{\circ} \mathrm{C}$ por um tempo total de 660 minutos, após a sua realização os rolos foram novamente submetidos ao processo de limpeza superficial através da utilização da solução ácida de $13 \%$ de H2SO4 e escovamento abrasivo. 


\section{Processo de laminação a frio}

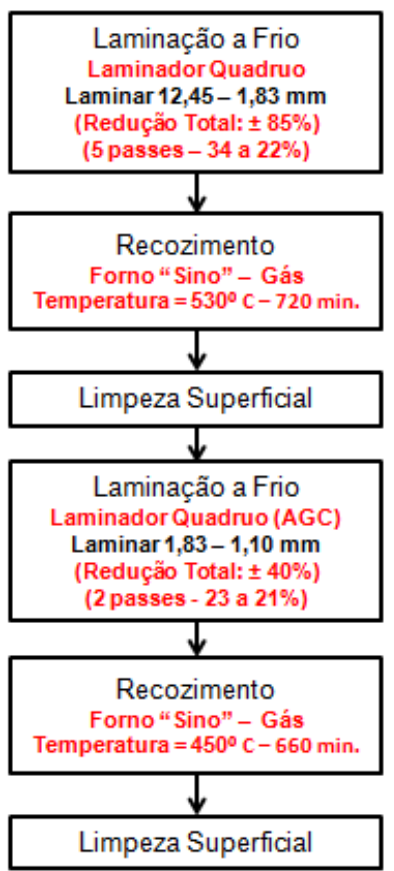

Figura 36 Fluxograma do processo de laminação a frio e acabamento para os processos de fundição contínua e fundição semicontínua.

\subsection{Análises metalograficas}

Após as análises macrográficas, amostras do processo F.C do material fresado de 12,50X20X30 mm foram cortadas em uma serra de fita vertical Starrett, modelo S2030, no meio e nas duas laterais da largura. Para o processo F.S.C do material fresado adotou-se o mesmo procedimento, cortando amostras de 12,40X20X30 mm, também no meio e nas duas extremidades da largura, ambas no sentido de laminação $0^{\circ}$ (Figura 37). Nas etapas de espessura intermediaria e de acabamento durante o processo de produção das chapas em que o material se encontrava no estado recozido, foram igualmente retiradas amostras para análise do tamanho de grão. Em função da diferença de aquecimento demonstrada no APÊNDICE A, mapeamento do forno de recozimento, as amostras foram sempre retiradas da mesma ponta, ou seja, a ponta em que se retirou as amostras para medição do tamanho de grão do material fresado, desta forma neutralizou-se a variável de aquecimento do forno ver APÊNDICE B, esquema de retirada de amostras tanto para o material no estado recozido como encruado. Conforme já mencionado anteriormente amostras de espessura x $650 \times 500 \mathrm{~mm}$, foram cortadas com uma 
tesoura elétrica Makita, modelo JS3201, em todas as etapas em que o material apresentou-se no estado recozido e com a guilhotina Motomil, modelo MTC-05 recortou-se amostras com dimensional da espessura da etapa de processo x 10X30 $\mathrm{mm}$ a $0^{\circ}$ do sentido de laminação nas duas laterais e no meio da largura total da chapa 650 mm (Figura 37), objetivando analisar o tamanho de grão dessas etapas.

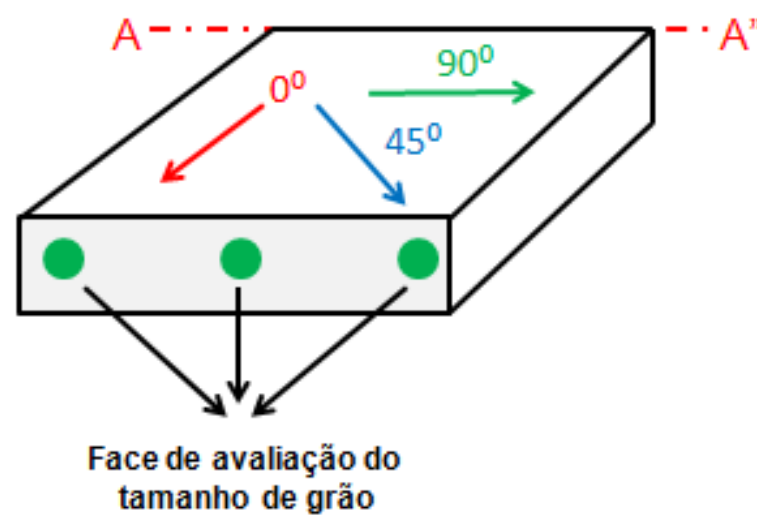

(a)

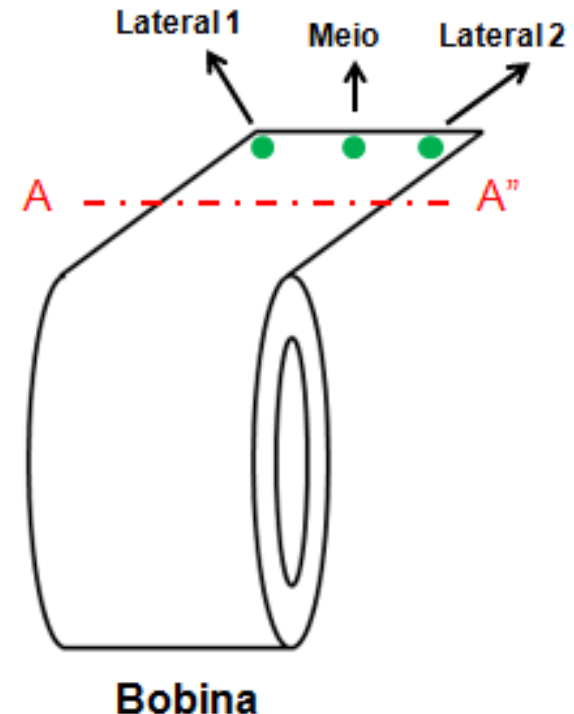

(b)

Figura 37 Esquema de retirada de amostra para análise macrografica (b) e metalografica (a) de tamanho de grão.

As amostras metalograficas, foram preparadas da seguinte forma; efetuou-se o embutimento a quente em resina termofixa de cura a quente (baquelite) na máquina Tempopress 2 da Struers à uma temperatura de $\pm 150^{\circ} \mathrm{C}$, por um tempo total de 20 minutos, obtendo-se corpos de prova cilíndricos com diâmetro de $30 \mathrm{~mm}$ e comprimento de $15 \mathrm{~mm}$. Essas amostras foram desbastadas mecanicamente em lixas de granulometria \#180, \#200, \#320, \#400, \#600, \#1000 e \#1200, invertendo o sentido de lixamento entre as lixas objetivando a remoção dos riscos provocados durante o processo de lixamento. Para a próxima etapa, o polimento eletrolítico, foi necessário então remover as amostras do baquelite com o auxílio de um martelo e uma morsa. Efetuou-se o polimento eletrolítico na máquina da Struers leoprol-5, utilizando uma solução de $40 \%$ de Ácido Fosfórico, por um período de 7 minutos, 
sendo as amostras enxaguadas em água corrente, álcool e secadas com sopro de ar quente.

As amostras metalograficas foram reveladas com a solução de Klemm II (mistura de solução aquosa saturada de tiossulfato de sódio $90 \mathrm{~g} \mathrm{em} 200 \mathrm{ml}$ de água destilada e $6 \mathrm{~g}$ de metabissulfito de potássio), por um tempo de 1 a 3 minutos, sendo também enxaguadas com água, álcool e sopro de ar quente para posterior avaliação do tamanho de grão. As amostras foram então analisadas no microscópio óptico vertical da marca Olympus modelo BX-60M, com aumentos de 50, 100, 200 e 500X.

\subsection{Medições de tamanho de grão}

A medição do tamanho de grão foi realizada utilizando-se as fotos e o software ImageJ, sendo medidos os perímetros de 150 grãos para o material fresado do processo de fundição contínua, em função do tamanho de grão detectado nesta etapa do processo e 450 grãos para as outras etapas, fresado fundição semicontínua mais laminação a quente, material intermediário e material acabado dos dois processos, obtendo-se consecutivamente a área dos grão e supondo que os grão possuem formatos circulares, extraindo-se o diâmetro dos grão através da equação $d_{T . G .}=\sqrt{\frac{A x 4}{\pi}}$, os dados obtidos nas medições foram analisados no software estatístico Minitab 16, sendo verificado o tipo de distribuição dos dados e construído histogramas para a avaliação da homogeneidade de distribuição através das Figuras gráficas.

\subsection{Preparações dos corpos de prova para ensaios de tração uniaxiais}

Assim como na análise metalografica, amostras para avaliação das propriedades físicas e mecânicas foram cortadas em todas as fases do processo de fabricação das chapas, seja material encruado ou recozido, sendo o dimensional da espessura da chapa X largura (650) X comprimento (500) em mm, objetivando posteriormente recortar na guilhotina Motomil, modelo MTC-05, 5 tiras de espessura 
da etapa do processo X20X260 mm, para cada ângulo estudado com relação ao sentido de laminação $0^{\circ}, 45^{\circ}$ e $90^{\circ}$ e realizar o fresamento dos corpos de prova, através de um gabarito metálico (Figura 38) que garante o dimensional exposto pela norma ASTM E - 8 utilizada para execução de ensaios de tração.

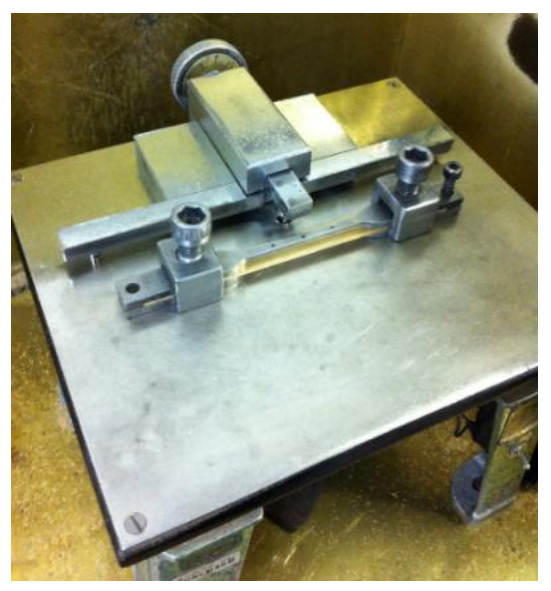

(a)

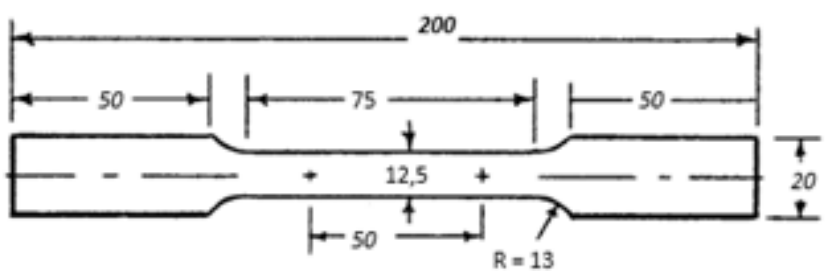

(b)

Figura 38 Confecção dos corpos de prova, (a) Fresa e gabarito para o fresamento dos corpos de prova e (b) Dimensional dos corpos de prova.

Após o fresamento dos corpos de prova, foram feitos acabamentos com uma lima meia cana de 4" e acabamento superficial com uma lixa de grana \#320. As medições das cotas dos corpos de prova foram efetuadas com micrometro Mitutoyo, modelo MDC-25SB, e paquímetro Mitutoyo, modelo 500-197-30B. Os ensaios de tração uniaxial foram efetuados em uma máquina de tração vertical da marca Tinus Olsen modelo $\mathrm{H} 25 \mathrm{KL}$ com velocidade inicial de $3 \mathrm{~mm} / \mathrm{min}$ até que seja atingido a tensão de $8 \mathrm{MPa}, 8 \mathrm{~mm} / \mathrm{min}$ até que se atinja a deformação de 0,02\%, $15 \mathrm{~mm} / \mathrm{min}$ até que se seja removido o extensometro e $30 \mathrm{~mm} / \mathrm{min}$ até o final do ensaio.

\subsection{Determinação dos coeficientes de anisotropia planar e normal}

O levantamento dos coeficientes de anisotropia planar $\Delta \mathrm{r}$ e anisotropia normal $r$, foram também determinados nas etapas em que o material se apresentava no estado recozido. A determinação dos coeficientes foi realizada de forma diferente a 
exposta pela norma ASTM E - 517, ou seja, os ensaios de tração uniaxial não foram interrompidos pela porcentagem de deformação de 15 a 20\%, conforme exposto pela norma ASTM. A deformação foi interrompida, quando o material alcançou uma força de $85 \%$ da força máxima evidenciada no corpo de prova ensaiado no sentido de laminação a $0^{\circ}$. Uma pesquisa prévia (Almeida e Schön (2016)) comprovou que em diferentes porcentagens de deformação, como por exemplo, 10, 15 e $20 \%$, os valores dos coeficientes não sofriam alterações significativas, portanto, adotou-se esse procedimento de interromper os ensaios pela força e não pela deformação, pois o equipamento utilizado nos ensaios não possuía o recurso de interromper o ensaio pela \% de deformação, devido ao comprimento atingido pelo extensometro utilizado.

Os corpos de prova foram então demarcados no centro com dois riscos transversais, sendo efetuada a medição da largura e espessura dentro das marcações centrais das amostras (Figura 39). As medições foram realizadas com o micrometro e paquímetro referenciados acima. Os corpos de prova foram ensaiados na Tinus Olsen modelo $\mathrm{H} 25 \mathrm{KL}$ com velocidade constante de $15 \mathrm{~mm} / \mathrm{min}$ e ao alcançar-se a força calculada ( $85 \%$ do total) o ensaio foi interrompido e realizou-se a medição da largura e espessura na mesma região. Com os dados obtidos foram calculados os índices de anisotropia plástica (R) para cada amostra e posteriormente calculou-se os coeficientes $\Delta r$ e $r$ através das equações disponibilizadas pela norma ASTM E - 517 .

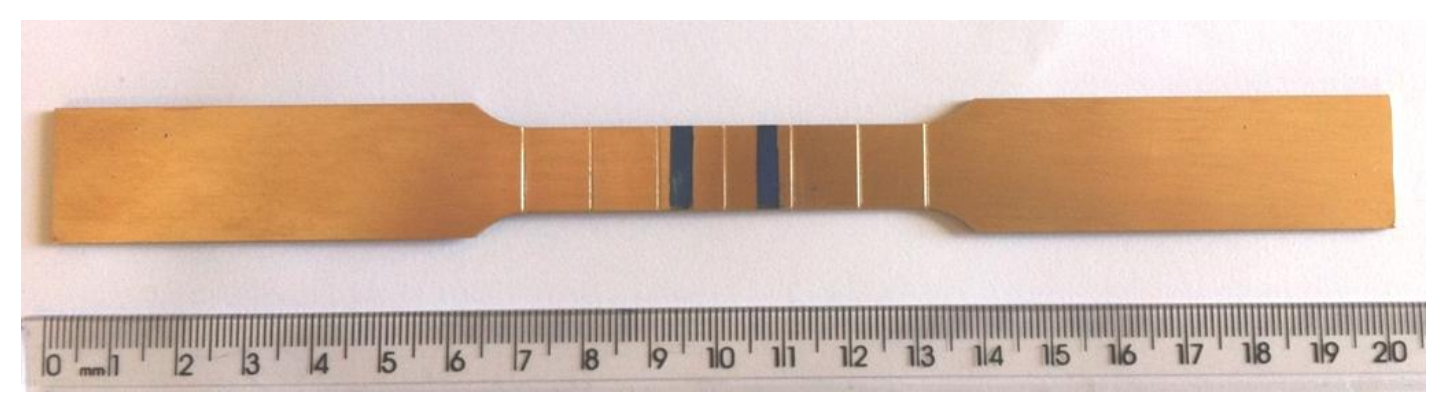

Figura 39 Marcação central do corpo de prova para a medição da largura e espessura para obtenção do $\Delta R$ e r. 
4.9 Determinações dos coeficientes de encruamento $n$ e coeficientes de resistência $\mathrm{K}$

A obtenção dos coeficientes $\mathrm{n}$ e $\mathrm{K}$ da equação de Hollomon foram também obtidos através dos ensaios de tração uniaxial e consecutivamente a extração dos dados após os ensaios. A tensão e o aumento do comprimento do corpo de prova (posição) foram extraídos do software da Tinus Olsen, equipamento utilizado nos ensaios de tração uniaxial já referenciado no texto acima. Os coeficientes foram obtidos apenas nos materiais em que se apresentavam em seu estado recozido, material intermediário e acabado mole e nos ângulos $0^{\circ}, 45^{\circ}$ e $90^{\circ}$ do sentido de laminação.

No software Excel construíram-se gráficos de tensão $x$ deformação real e a equação de potência elaborada apenas para os dados do limite de escoamento até o limite de resistência a tração alcançado (SOUZA, 1982), obtendo os valores de $\mathrm{n} e$ $\mathrm{K}$ na base de log (Figura 40).

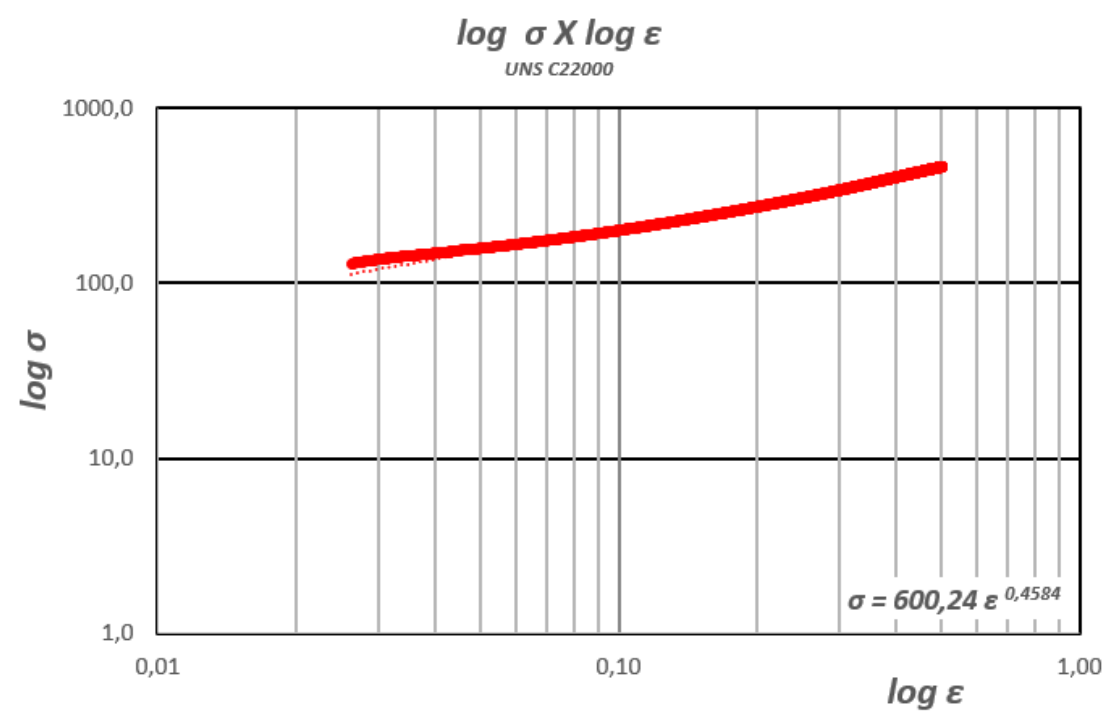

Figura 40 Exemplo de obtenção de K e $n$ através da equação de potência obtida no Excel.

A metodologia mais simples proposta para determinação dos coeficentes de encruamento $\mathrm{n}$ e resistência $\mathrm{K}$ é efetuada através da transformação da expressão $\sigma=K \varepsilon^{n}$ na base log e a construção da curva na mesma base log-log conforme demonstrado na Figura 40, obtendo-se a equação $\log \sigma=\log K+n \log \varepsilon$, desta forma 
se obtem um gráfico em linha reta. O coeficiente angular da reta é o valor de $\mathrm{n}$ e o valor alcançado para deformação verdadeira igual a 1 é o valor do coeficente de resistência K obtido conforme a Figura 41(SOUZA, 1982).

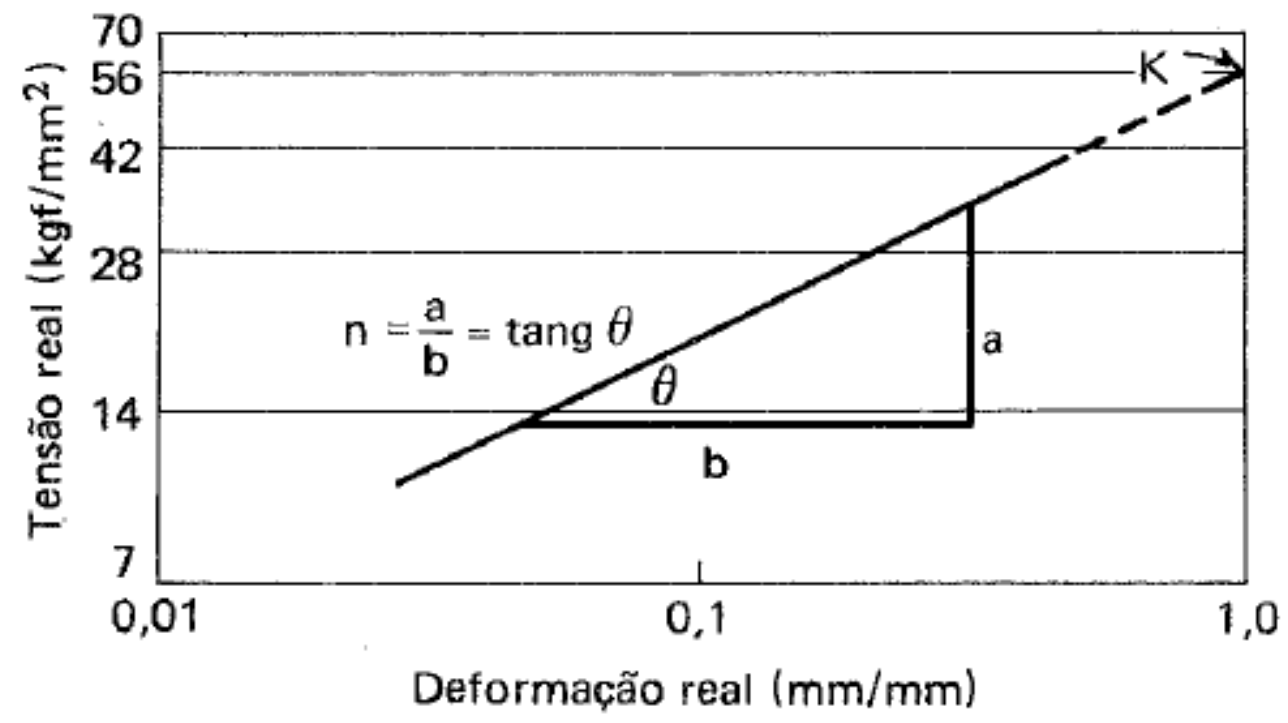

Figura 41 Determinação dos valores de n e K na curva log-log (SOUZA, 1982).

4.10 Ensaio de dureza e levantamento da curva de amolecimento

Os ensaios de dureza superficial foram realizados utilizando-se a escala HR30T, conforme indicado para o material em estudo pela norma ASTM B-36 que especifica as características a serem seguidas para o fornecimento de tiras e chapas de latão.

Amostras foram cortadas na guilhotina Motomil, modelo MTC-05 em todas as etapas do processo de fabricação dos rolos para análise de dureza, espessura da etapa X 30 X $30 \mathrm{~mm}$. Com o durômetro Rockwell superficial da marca Wilson Mechanical Instrument Co. inc., efetuou-se os ensaios. As amostras foram centralizadas na mesa plana do durômetro de diâmetro de $10 \mathrm{~mm}$ e através da rotação das alavancas inferiores de acerto da mesa, ajustou-se a pré-carga, impondo a amostra contra o penetrador de aço com esfera de 1/16" e zerando o indicador da pré-carga, acionou-se a alavanca de ensaio do equipamento e após 20 
segundos posicionou-se a alavanca para posição inicial e efetuou-se a leitura da dureza no mostrador.

As curvas de amolecimento foram elaboradas apenas na etapa final, ou seja, amostras do material encruado na espessura final de 1,10 mm. Cortaram-se vinte e duas amostras de $1,10 \times 20 \times 40 \mathrm{~mm}$, sendo onze amostras do processo F.C. e onze amostras do processo F.S.C.. Os corpos de prova foram então submetidos ao tratamento térmico de recozimento no forno "Mufla" a $450^{\circ} \mathrm{C}$, por períodos de 5,10 , 15, 20, 40, 50, 60, 70, 80 e 1278 minutos. Das vinte e duas amostras analisou-se a dureza do material encruado de cada processo, restando vinte amostras que foram colocadas no forno "mufla" e após os tempos descritos acima se retirou as amostras do forno e efetuou a medição das durezas conforme descrito no texto acima.

4.11 Confecções dos corpos de prova para elaboração da curva limite de conformação através dos ensaios de tração uniaxiais

Para o levantamento do lado esquerdo da curva limite de conformação foi necessário confeccionar quatro corpos de prova de formato diferenciados propostos pelo IRSID ("Institut de Recherches de la Sidérurgie”) (Figura 42), conforme já mencionado anteriormente, sendo preciso a elaboração de cinco corpos de prova de cada dimensional e processo no sentido de laminação a $0^{\circ}$. Os cortes dos corpos de prova foram efetuados na máquina de eletroerosão a fio da marca Suzhou Sanguang, modelo DK7625P, devido à complexidade das dimensões e 0 acabamento do corte proporcionado pelo processo de eletroerosão, pois cortes efetuados através de guilhotinas, serras e fresas proporcionam certas deformidades como micro-trincas e pequenas fissuras que aceleram o processo de rompimento dos corpos de prova e consecutivamente distorcem os resultados esperados. Dois conjuntos, um de cada processo, com oito chapas de dimensional 300X300X1,10 $\mathrm{mm}$, foram posicionadas umas sobre as outras, em formato de "sanduiche", obtendo uma placa de $300 \times 300 \times 8,80 \mathrm{~mm}$ para o corte das amostras, sendo o corte efetuado na máquina com o posicionamento da placa na mesa e a disperção de água desmineralizada e deionizada durante o corte com o fio de latão UNS C27000 de diâmetro de 0,25 mm, voltagem de $42 \mathrm{~V}$, corrente de 11,1 A e velocidade de 13 
$\mathrm{mm} / \mathrm{min}$, obtendo no corte um acabamento com rugosidade de $0,28 \mu \mathrm{m}$, julgando-se desnecessario efetuar o acabamento do corte com lixa.

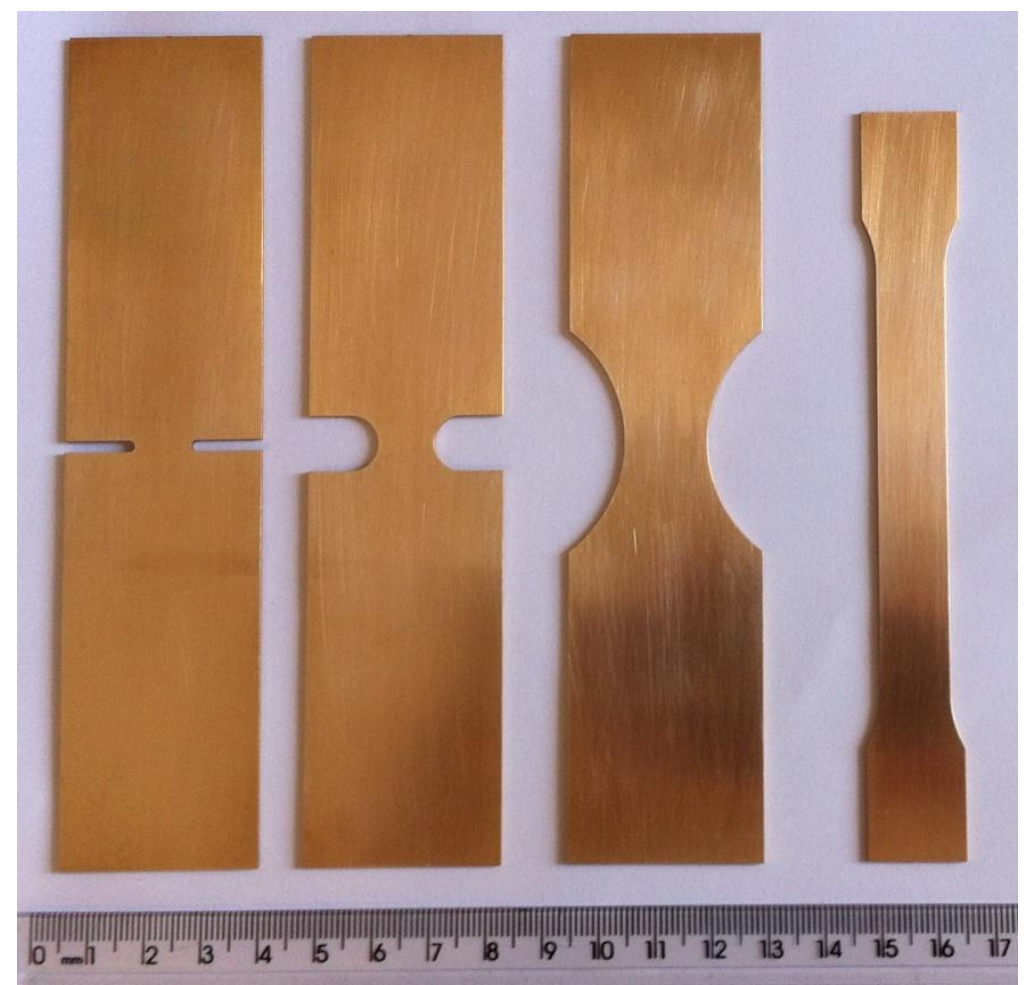

Figura 42 Corpos de prova cortados na eletroerosão (IRSID -“Institut de Recherches de la Sidérurgie").

4.12 Confecções dos corpos de prova para elaboração da curva limite de conformação através dos ensaios Nakazima reduzido

Os corpos de prova preparados para a realização do ensaio Nakazima reduzido, foram elaborados em conformidade com a norma ISO 12004-2, porém, com as dimensões reduzidas em $60 \%$, a cota W demonstrada na Figura 43 apresenta os valores utilizados por Schwindt et al (2015), ou seja, $W=20 \mathrm{~mm}, 40$ $\mathrm{mm}, 50 \mathrm{~mm}, 55 \mathrm{~mm}, 60 \mathrm{~mm}, 70 \mathrm{~mm}$ e $80 \mathrm{~mm}$ e foram utilizados no presente estudo. Conforme descrito anteriormente o processo de corte efetuado pela eletroerosão a frio disponibiliza um excelente acabamento e, portanto, utilizado para cortar os corpos de prova do ensaio Nakazima reduzido. 


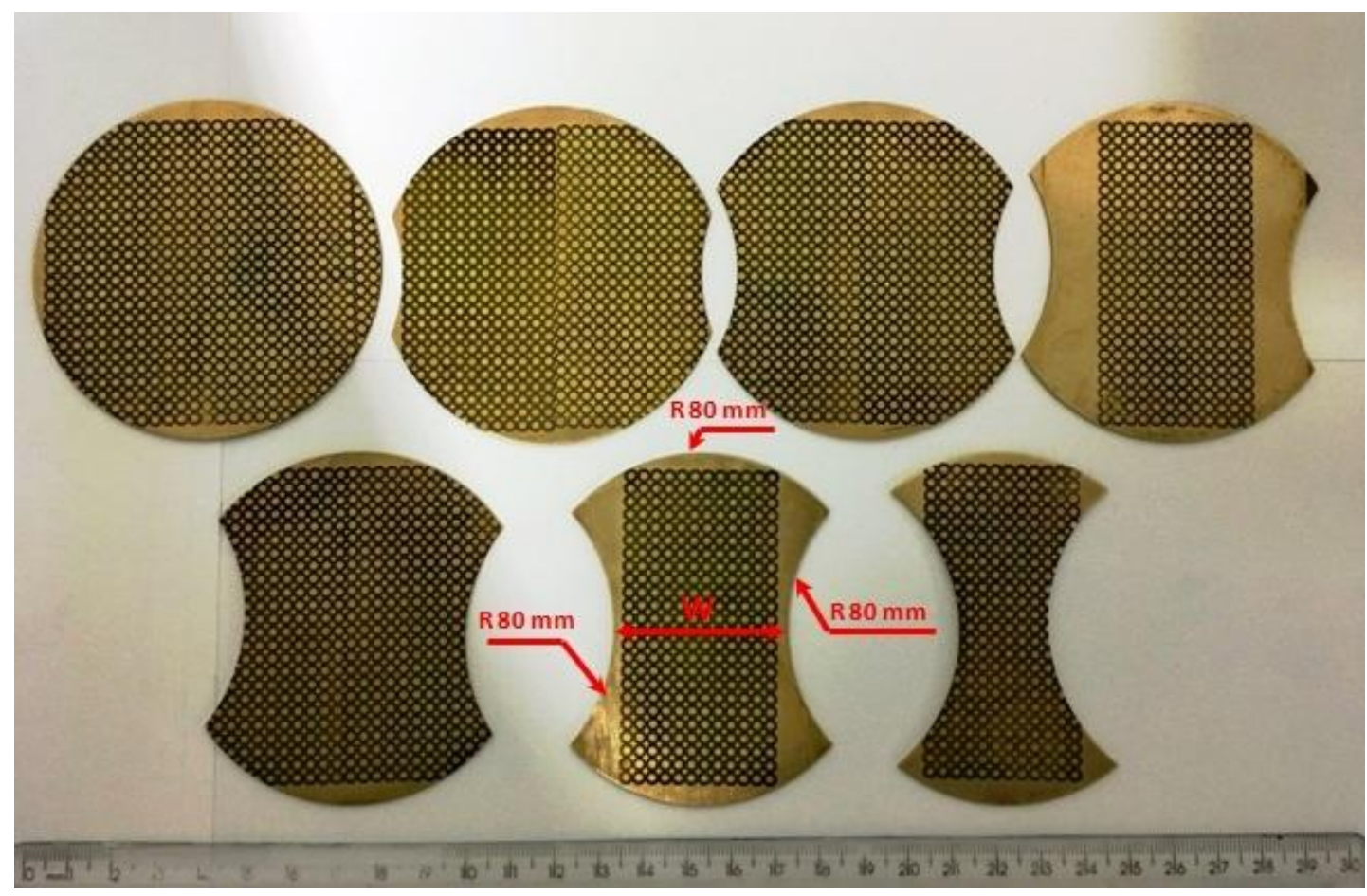

Figura 43 Corpo de prova para ensaio Nakazima reduzido.

4.13 Estampagem dos círculos nos corpos de prova de ensaio de tração uniaxiais (serigrafia)

Os círculos gravados nos corpos de prova objetivando a posterior medição da deformação são originários geralmente de três processos distintos, sendo através da corrosão eletroquímica, serigrafia e roto-gravura, possuindo cada um uma determinada particularidade. A corrosão eletroquímica apresenta círculos com pequena nitidez, dependendo da solução e tempo utilizados na gravação dos círculos, e ao ser efetuada a deformação dos corpos de prova se torna ainda mais difícil à medição dos círculos. Os processos de serigrafia e roto-gravura são similares com relação à nitidez, ainda mais para deformações no plano da chapa (uniaxial), porém, após a conformação a roto-gravura possui uma nitidez levemente superior e ainda pode ser melhorada com a colocação das amostras em um tempo exato de exposição ao cloreto férrico, parte integrante do processo de confecção dos círculos, valendo ressaltar que o processo de roto-gravura pode apresentar trincas, devido ao tempo excessivo de exposição à solução de cloreto férrico utilizada no processo de gravação. Levando em consideração o custo e facilidade de obtenção 
dos processos optou-se no presente estudo pela utilização do processo de serigrafia para os corpos de prova de ensaio de tração uniaxiais, devido à nitidez apresentada pelos círculos, facilidade e custo intermediário entre os processos referenciados Xavier, Sousa, Lopes e Plaut (2006).

Posteriormente os corpos de prova foram estampados pelo processo de serigrafia, sendo adquirida uma tela de $300 \times 400 \mathrm{~mm}$, de nylon 100 fios com gravação emulsão resistente a solvente com uma malha contendo diâmetros internos de $2 \mathrm{~mm}$, conforme recomendado pela norma ASTM E-2218 e diâmetro externo de 2,5 mm. A tinta utilizada no processo de serigrafia foi a tinta epóxi (2 componentes) preto para serigrafia em metais da marca Saturno e o catalisador (2 componentes) da mesma marca. Utilizou-se solvente para limpeza dos dispositivos utilizados no processo de estampagem dos círculos nos corpos de prova (Figura 44).

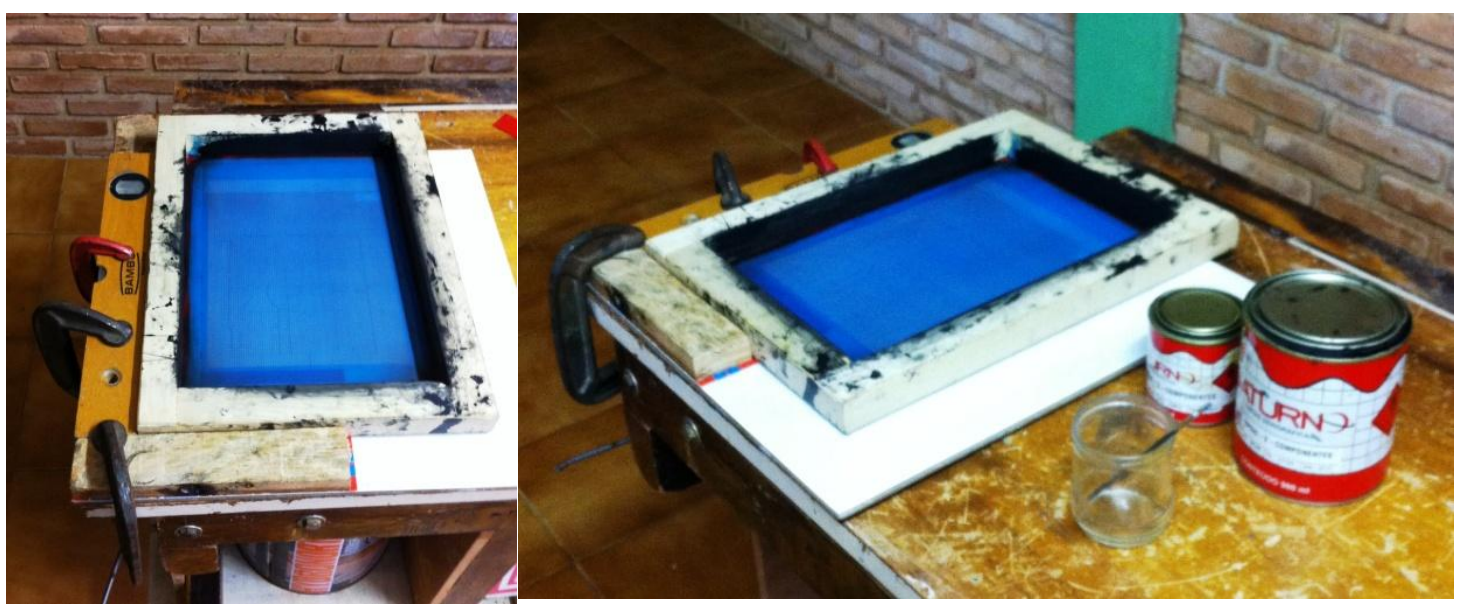

Figura 44 Tela, tinta e catalizador utilizados para a estampagem dos círculos nos corpos de prova.

A mistura utilizada na estampagem foi preparada com $80 \%$ de tinta e $20 \%$ de catalisador. As superfícies dos corpos de prova foram lixadas levemente com uma lixa de \#1000, limpas com um pano e álcool e na sequencia despejou-se a tinta na tela e espalhou-se com uma espátula, com a pressão exercida pelo "rodo" sobre tela e a passagem da tinta pelos furos presentes na tela surgiu o desenho objetivado (Figura 45). 

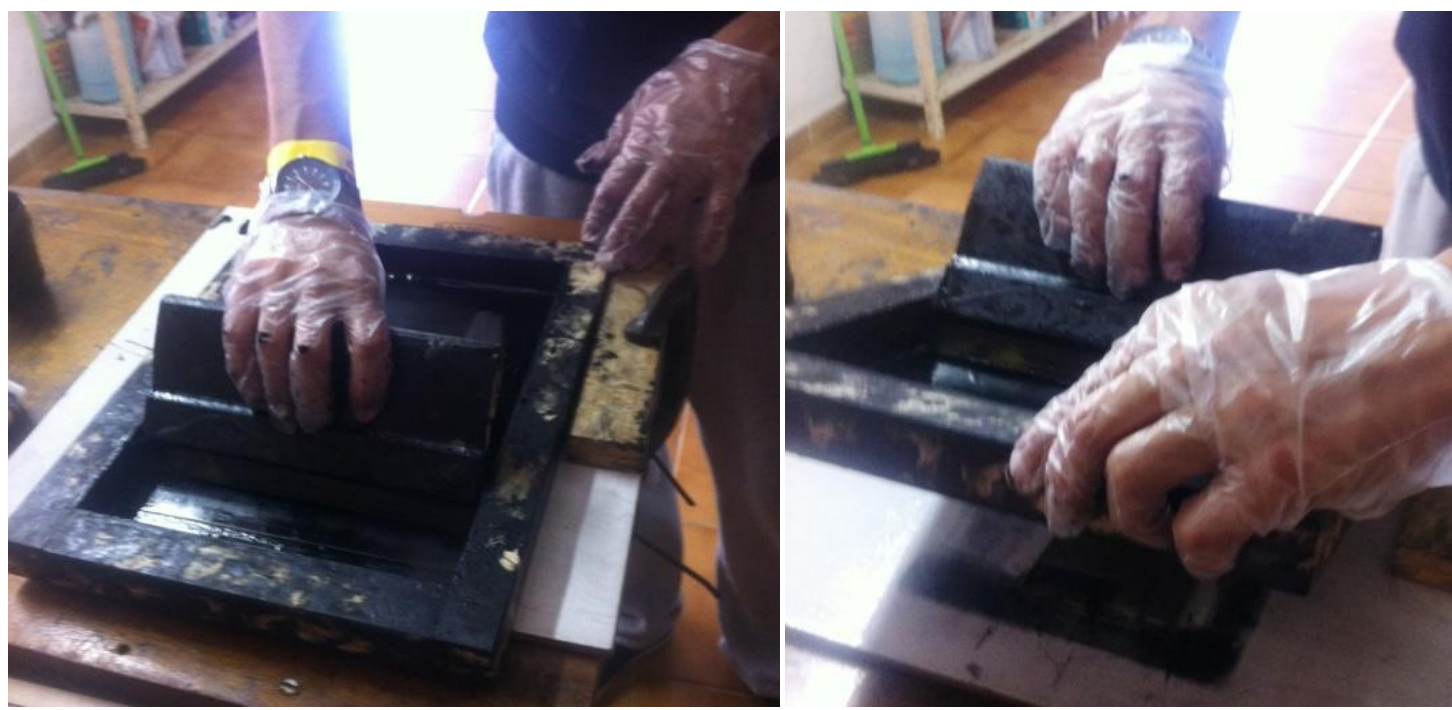

Figura 45 Estampagem dos corpos de prova.

As estampagens dos círculos foram efetuadas nos corpos de prova por inteiro, totalizando a confecção de quarenta corpos de prova para ensaio de tração uniaxial (Figura 46).

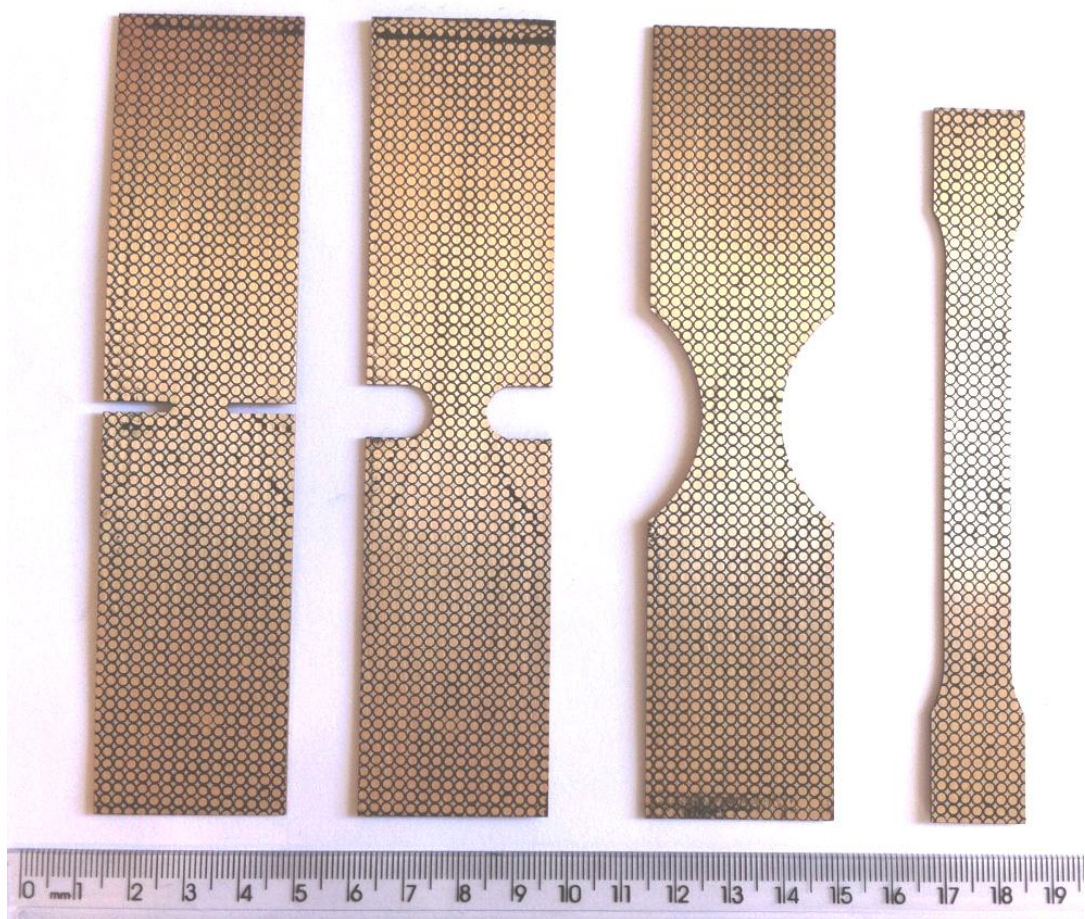

Figura 46 Corpos de prova estampados (IRSID -“Institut de Recherches de la Sidérurgie”). 
4.14 Estampagem dos círculos nos corpos de prova de ensaio Nakazima reduzido e ensaio Erichsen (corrosão eletroquímica)

Os corpos de prova utilizados no ensaio Nakazima reduzido sofrem deformações fora do plano, ou seja, influência do atrito entre o punção e o material. Desta forma, o processo de gravação dos círculos pelo método de serigrafia, deve suportar tal deformação sem que haja o "desplacamento" da tinta após a realização dos ensaios, tornando possível a medição da deformação. Em função da nitidez e o "desplacamento" obtidos nos corpos de prova de ensaio Erichsen que possuíam círculos estampados pelo processo de serigrafia, optou-se pela utilização da técnica de corrosão eletroquímica, devido ao custo e facilidade de estampagem dos círculos.

A gravação eletroquímica dos círculos com diâmetro interno de $2,00 \mathrm{~mm}$ e externo de 2,50 $\mathrm{mm}$, realizada na superfície dos corpos de prova foram efetuadas através de duas etapas, sendo a primeira etapa a limpeza dos corpos de prova e a segunda etapa a gravação dos círculos nas amostras.

A limpeza foi efetuada através do lixamento da superfície com uma lixa de grana \#600, limpeza com água, álcool e secagem com sopro de ar quente. Para as gravações utilizou-se o aparelho Mark 31 da Tecnigrav, posicionando os corpos de prova sobre a chapa ligada no equipamento pelo fio vermelho da Figura 47, colocando a tela ("stencil") verde sobre as amostras, com o carimbo eletroquímico impregnado com a solução de Triódio de Cromo $\left(1,9 \% \quad \mathrm{CrO}_{3}\right)$, água destilada e tensoativo (RSM 2) e ligado no equipamento pelo fio preto Figura 47, efetuou-se a gravação com movimentos do carimbo sobre a superfície da tela no sentido longitudinal sobre os corpos de prova Figura 47. 


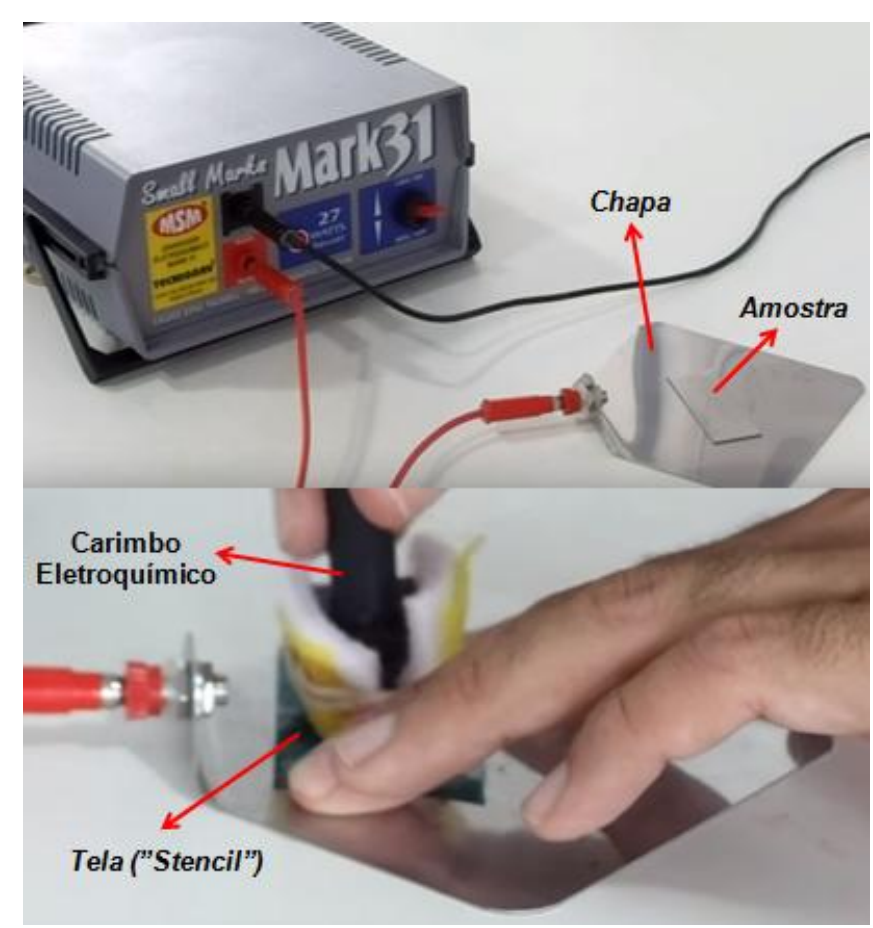

Figura 47 Estampagem dos círculos eletroquimicamente.

4.15 Ensaios para levantamento das curvas limites de conformação (Corpos de prova de tração uniaxiais)

Dois estudos prévios foram necessários para sanar algumas dúvidas com relação aos círculos estampados, sendo ambos devido a uma pequena deformidade apresentada pelos círculos, após o processo de estampagem pelo método de serigrafia Figura 48.
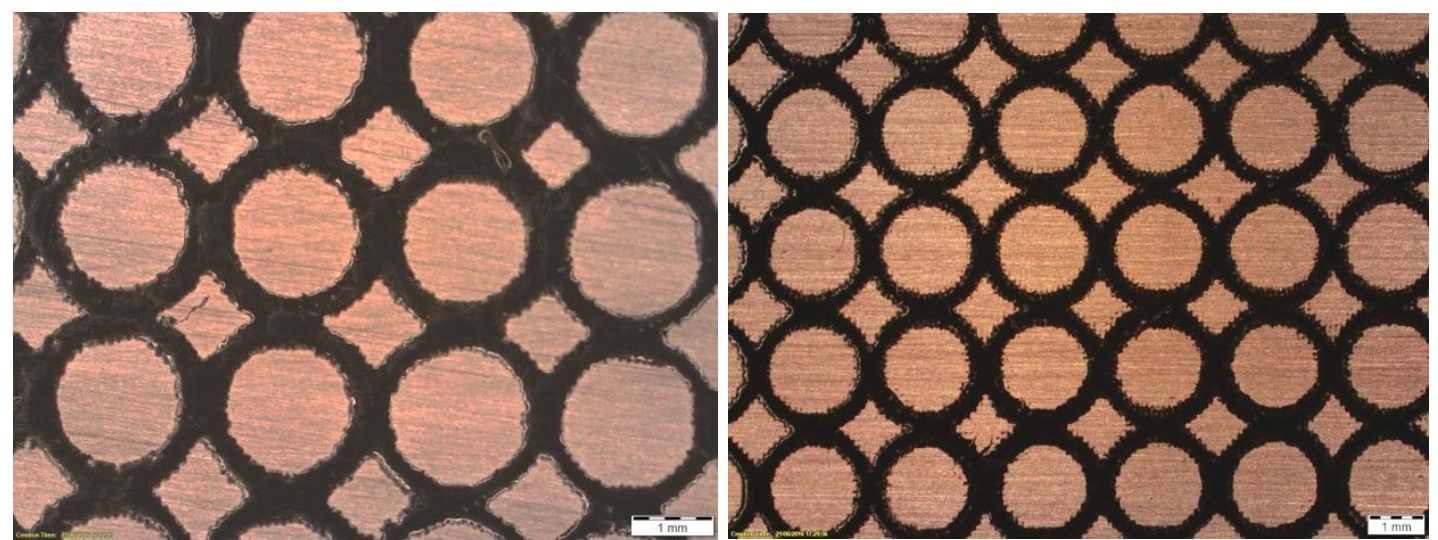

Figura 48 Círculos estampados pelo processo de serigrafia. 
Como já mencionado no paragrafo anterior os círculos apresentaram pequenas deformidades ao serem estampados, ou seja, não apresentaram um círculo perfeito com diâmetro interno de 2,00 mm conforme recomendado pela norma ASTM E 2218. Desta forma realizou-se o primeiro estudo prévio. A medição dos círculos foi efetuada somente após o ensaio, considerando um diâmetro interno fixo de 2,00 mm e os resultados obtidos foram comparados com corpos de prova em que foi efetuado a medição do diâmetro interno dos círculos antes e após os ensaios no sentido de laminação e oposto ao sentido de laminação, 0 e $90^{\circ}$ (vide Figura 49). Os resultados obtidos para o teste do diâmetro interno fixo de 2,00 mm não apresentaram resultados consistentes, pois nos corpos de prova que sofreram pequenas deformações os diâmetros internos dos círculos apresentaram-se muito próximos de $2,00 \mathrm{~mm}$ e com isso distorceu os valores de $\varepsilon_{1}$ e $\varepsilon_{2}$ calculados. $O$ teste medindo $O$ diâmetro interno nos dois sentidos antes e após os ensaios apresentaram resultados muito mais consistentes e desvios padrões inferiores, quando comparados com a medição somente após o ensaio. Baseado nos resultados analisados previamente adotou-se esse procedimento para a obtenção da deformação e consecutivamente a construção das curvas limites de conformação.

O segundo estudo prévio objetivou-se verificar se a quantidade de círculos analisada por corpo de prova seria o suficiente para se obter uma média confiável devido a pequena deformidade presente nos círculos estampados. Desta forma foram ensaiados um conjunto de corpos de prova (4 corpos de prova) estampados com o dimensional proposto obtendo-se em média 4 círculos por corpo de prova para a obtenção da média utilizada na construção da curva limite de conformação e um conjunto de corpos de prova com o dobro do dimensional proposto pelo IRSID ("Institut de Recherches de la Sidérurgie"), obtendo-se 6 círculos por corpo de prova para se determinar a média, aumentado em $\pm 33 \%$ o número de amostragem, sendo possível concluir que as pequenas deformidades não influenciariam na média amostral e os desvios padrões não apresentaram diferenças significativas, comprovando que as pequenas deformidades dos círculos não influenciaram nos resultados.

As regiões de entalhe dos corpos de prova foram submetidas à medição dos diâmetros, conforme a Figura 49, antes da realização dos ensaios, conforme já mencionado anteriormente. As medições foram efetuadas no microscópio estéreo 
Olympus, modelo SZX7 Zoom, sendo possível a realização das medições em todos os corpos de prova antes e após os ensaios realizados.

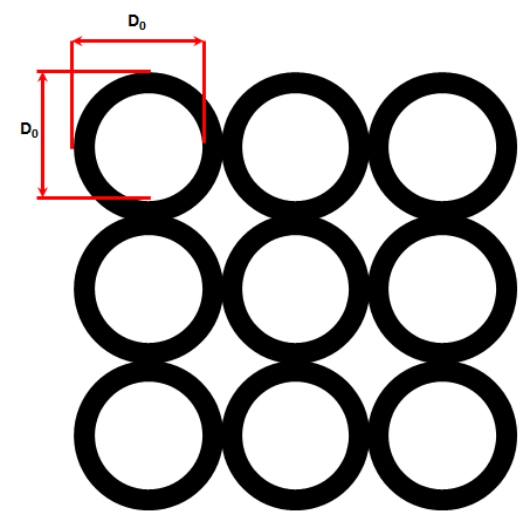

(a)

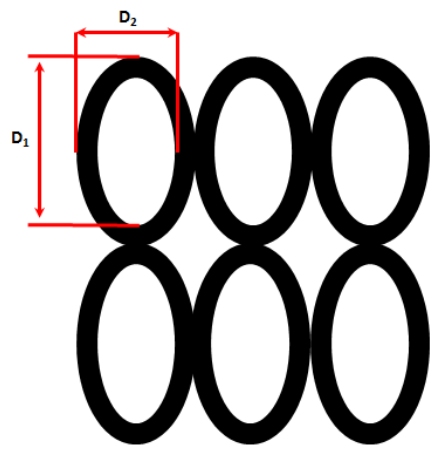

(b)

Figura 49 Forma de medição dos círculos antes (a) e após os ensaios (b).

As amostras foram então ensaiadas na máquina de tração Tinus Olsen, modelo H25 KL, com uma velocidade fixa de $15 \mathrm{~mm} / \mathrm{min}$. As medições dos círculos para o cálculo da deformação foram realizadas nos círculos posicionados abaixo da fratura evidenciada nos corpos de prova conforme a figura 50. O levantamento das curvas limite de conformação foram então construídas com o auxílio do software Excel.

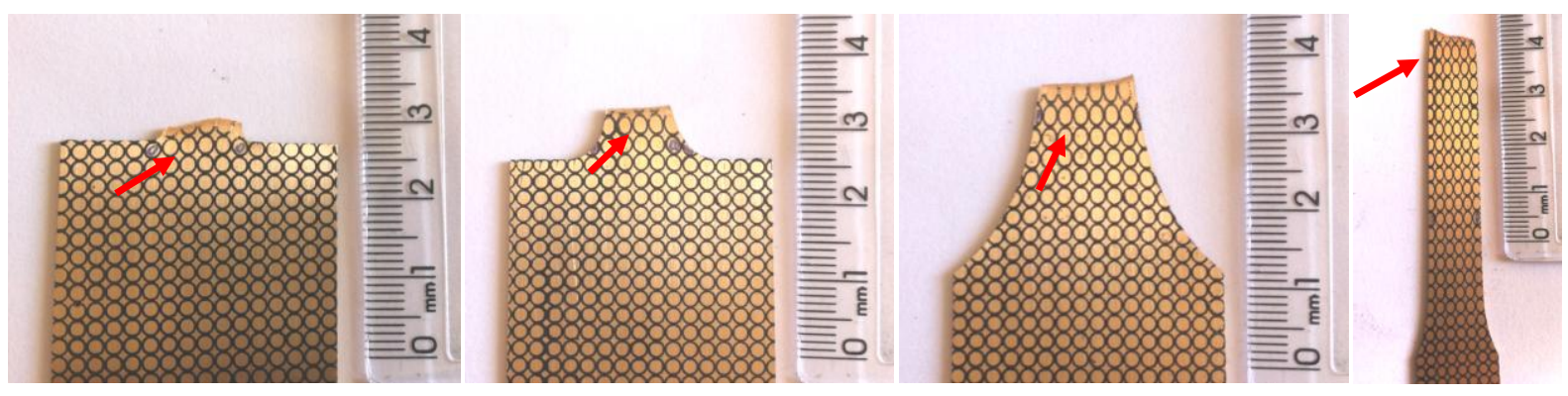

Figura 50 Demonstração da região de medição dos círculos após a realização dos ensaios de tração uniaxial.

4.15.1 Ensaio Erichsen para curva limite de conformação obtida pelo método IRSID

O ensaio Erichsen foi utilizado para o levantamento do lado direito da curva limite de conformação, visto que os corpos de prova de tração propostos são 
utilizados somente para a obtenção do lado esquerdo da curva. Desta forma como no ensaio Erichsen se possibilita a ocorrência da deformação biaxial, ou seja, nos dois sentidos da chapa que compõe o lado direito da curva limite de conformação foi o ensaio escolhido. Dez amostras de dimensional $90 \times 90 \mathrm{~mm}$ foram estampadas pelo processo de corrosão eletroquímica, conforme descrito anteriormente, realizando posteriormente a medição do diâmetro interno dos círculos no microscópio estéreo Olympus, modelo SZX7 Zoom, antes dos ensaios nos dois sentidos 0 e $90^{\circ}$. Os corpos de prova foram então ensaiados na máquina Erichsen, modelo 134, com uma força de 10 kN no prensa fitas, o punção de diâmetro de 20 $\mathrm{mm}$ foi lubrificado com vaselina industrial sólida. Após o posicionamento das amostras centralizando-as no equipamento, acionou a movimentação do punção de baixo para cima através do anel de fixação e da matriz superior, dando forma à calota produzida no ensaio, obtendo-se desta forma o índice Erichsen - que é a altura alcançada pela chapa após o processo de conformação e consecutivamente seu rompimento, posteriormente realizou-se novamente no microscópio estéreo Olympus, modelo SZX7 Zoom as medições dos diâmetros dos círculos próximos aos rompimentos dos corpos de prova e no software Excel foi possível calcular a deformação média de cada processo F.C e F.S.C. para a construção do lado direito da curva limite de conformação.

\subsection{Ensaio Nakazima reduzido}

Os ensaios Nakazima reduzido foram realizados na máquina de ensaios de compressão da Kratos, com célula de carga de 10.000 kgf e velocidade de deslocamento de $15 \mathrm{~mm} / \mathrm{min}$. Assim como os corpos de prova, o ferramental possui dimensões $60 \%$ menores as descritas na norma ISO 12004-2, possuindo o punção de formato hemisférico e diâmetro de $40 \mathrm{~mm}$. As amostras foram lubrificadas com graxa Molykote (Longterm W2) e posicionadas na parte superior da ferramenta inferior e a ferramenta superior colocada sobre as amostras, quatro parafusos fixaram uma ferramenta contra a outra conforme a Figura 51. Posicionou-se o ferramental sobre uma base metálica de diâmetro de $250 \mathrm{~mm}$ acoplada à garra inferior da máquina, sendo o punção apoiado com um calço de $30 \mathrm{~mm}$ de altura e 40 
$\mathrm{mm}$ de diâmetro na haste superior do equipamento. $\mathrm{O}$ software disponibilizado pela Kratos para realização de ensaios de compressão controla graficamente o aumento da carga com a deformação do material e após o rompimento dos corpos de prova interrompe o ensaio.

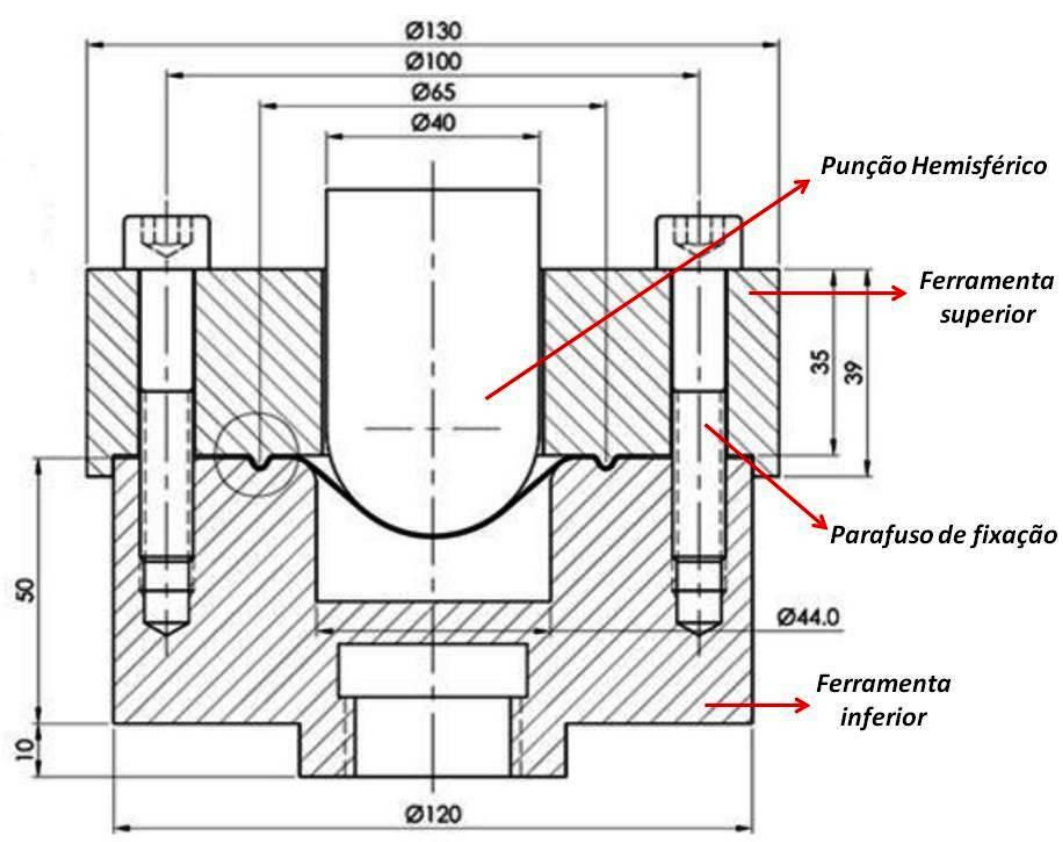

Figura 51 Ferramental utilizado no ensaio Nakazima reduzido (adaptado de SCHWINDT, 2014).

4.17 Ensaios de obtenção da curva limite de conformação raiz $\left(\mathrm{CLC}_{0}\right)$

A raiz $\left(C L C_{0}\right)$ é o ponto mais importante da CLC, conforme descrito anteriormente. Em função de sua importância julgou-se necessário sua obtenção no plano da chapa conforme os estudos desenvolvidos por Wagoner (1980 e 1981), Björklund e Nilsson (2014) e comparou-se com o resultado obtido na CLC determinada pela metodologia descrita pelo IRSID. 


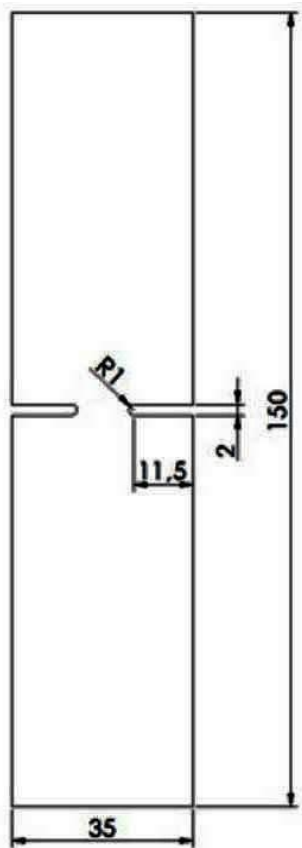

Figura 52 Corpo de prova para medição da deformação planar, metodologia proposta pelo IRSID (adaptado de SCHWINDT, 2014).

Para determinação da deformação planar foram confeccionados para cada processo de fabricação (F.C. e F.S.C.) três corpos de prova de cada autor, ou seja, três corpos de prova do Björklund e Nilsson (2014) Figura 24, três iguais ao da Figura 52, e por fim produziram-se três corpos de prova com dimensões seis vezes menor ao proposto por Wagoner (1981), com comprimento de $150 \mathrm{~mm}$, corpo de prova tipo $\mathrm{H}$ já exposto na Figura 23. $\mathrm{O}$ corpo de prova reduzido é demonstrado a seguir na Figura 53.

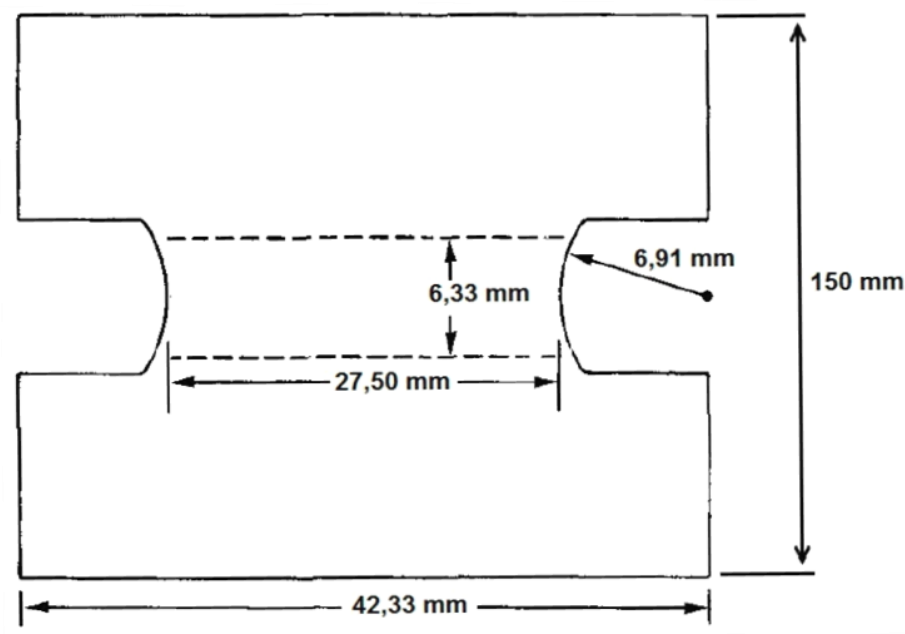

Figura 53 Corpo de prova reduzido em 6 vezes do proposto por Wagoner (1981) tipo H com comprimento de $150,00 \mathrm{~mm}$. 
Os corpos de prova foram cortados na eletroerosão em função do dimensional e do excelente acabamento obtido pelo processo, conforme já mencionado. As gravações dos círculos foram efetuadas pelo processo de corrosão eletroquímica, conforme item 4.14 descrito acima, nas regiões centrais dos corpos de prova e as circunferências foram medidas antes e após os ensaios de tração uniaxial no microscópio estéreo Olympus, modelo SZX7 Zoom, os ensaios foram efetuados na máquina de tração Tinus Olsen, modelo H25 KL, com uma velocidade fixa de $15 \mathrm{~mm} / \mathrm{min}$.

\subsection{Análise de Textura}

A textura foi mensurada por difração de raios-x sendo efetuada inicialmente em todas as etapas do processo de fabricação das chapas. Primeiramente retiraram-se amostras de $20 \times 10 \mathrm{~mm}$ no centro das chapas (vide Figura 54 (a)), recortando-as na guilhotina Motomil, modelo MTC-05. Em função da quantidade de amostras e etapas de fabricação, optou-se por verificar sempre a região central da espessura, vide Figura 54 (b). Desta forma, lixaram-se as amostras em lixas de grana \#120, \#320, \#600 até 30\% da espessura do material, posteriormente corroeuse $28,5 \%$ da espessura em solução contendo $54 \%$ de Ácido Nítrico (HNO) e o restante água, ou seja, a amostra de espessura $1,10 \mathrm{~mm}$ foi lixada até $0,77 \mathrm{~mm}$ e corroída até $0,55 \mathrm{~mm}$. Esse procedimento foi adotado para todas as amostras.

Utilizou-se o difratômetro de raio-x Rigaku DMAX Rint 2000, pertencente ao Instituto de Pesquisas Energéticas e Nucleares / Comissão Nacional de Energia Nuclear (IPEN / CNEN-SP), operando com uma voltagem de $50 \mathrm{KV}$, voltagem do tubo de cromo de $40 \mathrm{KV}$ e corrente do tubo de $20 \mathrm{~mA}$ (comprimento de onda de radiação $\mathrm{Cr} K, \lambda=0,229092 \mathrm{~nm}$ ), para a análise da varredura de uma amostra $\mathrm{e}$ verificação da intensidade e consecutivamente os ângulos de medição da textura, detectando os ângulos $2 \Theta 66,26^{\circ}$ (111), 78,20 (200) e 126,06 (220). Diante dos ângulos detectados, elaboraram-se as figuras de pólo de todas as amostras. 


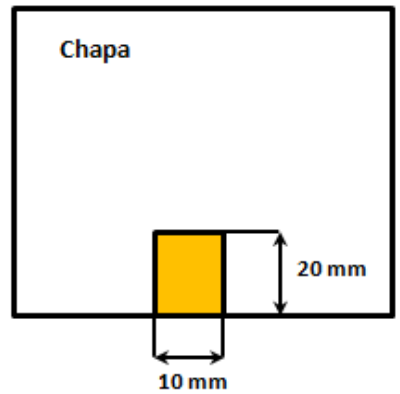

(a)

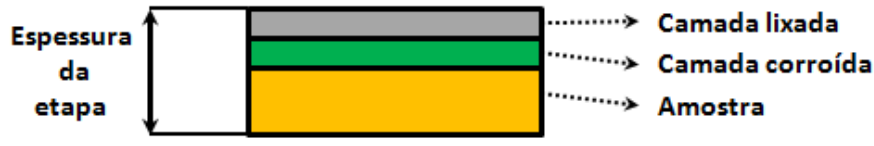

(b)

Figura 54 (a) Corte das amostras no centro das chapas e (b) remoção das camadas por lixamento e corrosão para análise da textura no centro da espessura do material.

Após as análises prévias, principalmente através das figuras de pólo, ou seja, simetria obtida nas figuras verificou-se que em função do tamanho de grão dos materiais analisados e do campo (área de avaliação das amostras) analisado, que não seria possível obter dados estatisticamente concretos para a avaliação correta da textura presente nas etapas de processo. Desta forma, julgou-se interessante aumentar o dimensional das amostras analisadas e consecutivamente o campo de análise de $20 \times 10 \mathrm{~mm}$ para $25 \times 20 \mathrm{~mm}$ no centro da espessura, da mesma forma e realizar as análises apenas nas amostras dos materiais com espessura de 1,10 mm encruado (duro) e mole em função dos tamanhos de grão obtidos e a simetria detectada nas figuras de pólo inicialmente das outras etapas de processo.

As avaliações das texturas presentes nas etapas de processo foram efetuadas através dos dados gerados na elaboração das figuras de pólo e das consequentes funções de distribuições de orientações cristalograficas (FDO's), utilizando-se o programa de análise de textura (PAT), desenvolvido pelo Dr. Nelson Batista de Lima e o Dr. Eguiberto Galego. 


\section{RESULTADOS E DISCUSSÃO}

\subsection{Caracterização do material como recebido}

As composições químicas dos materiais utilizados no presente estudo apresentaram valores dos elementos químicos considerados como impurezas muito inferiores aos especificados pelas normas de referência ASTM B 130 e B 131. A tabela 2 demonstra os teores de cobre, zinco e principalmente dos elementos considerados como impureza, ferro, estanho, cromo e cádmio, obtendo-se nos dois processos uma composição química com um nível de impureza desprezível, somatória de impurezas total inferior a 0,0162 \%, o teor de bismuto especificado pelas normas não foi detectado em nenhuma das bobinas.

Nas análises macrograficas realizadas nas bobinas fresadas detectou-se uma diferença bastante significativa podendo ser evidenciada através das fotos e da quantificação do tamanho de grão obtido em cada processo, sendo posteriormente demonstrados na tabela 3 e através das fotos das macrografias expostas na Figura 55. A Figura 55 demonstra o resultado das macrografias realizadas nas superfícies das placas, para o processo de fundição contínua (a) é possível visualizar grão alongados no sentido de laminação a $0^{\circ}$, para o processo de fundição semicontínua mais o processo de laminação a quente, não é possível visualizar o tamanho de grão em função do seu tamanho, desta forma o correto é fazer a preparação metalografica conforme demonstrado na Figura 58.

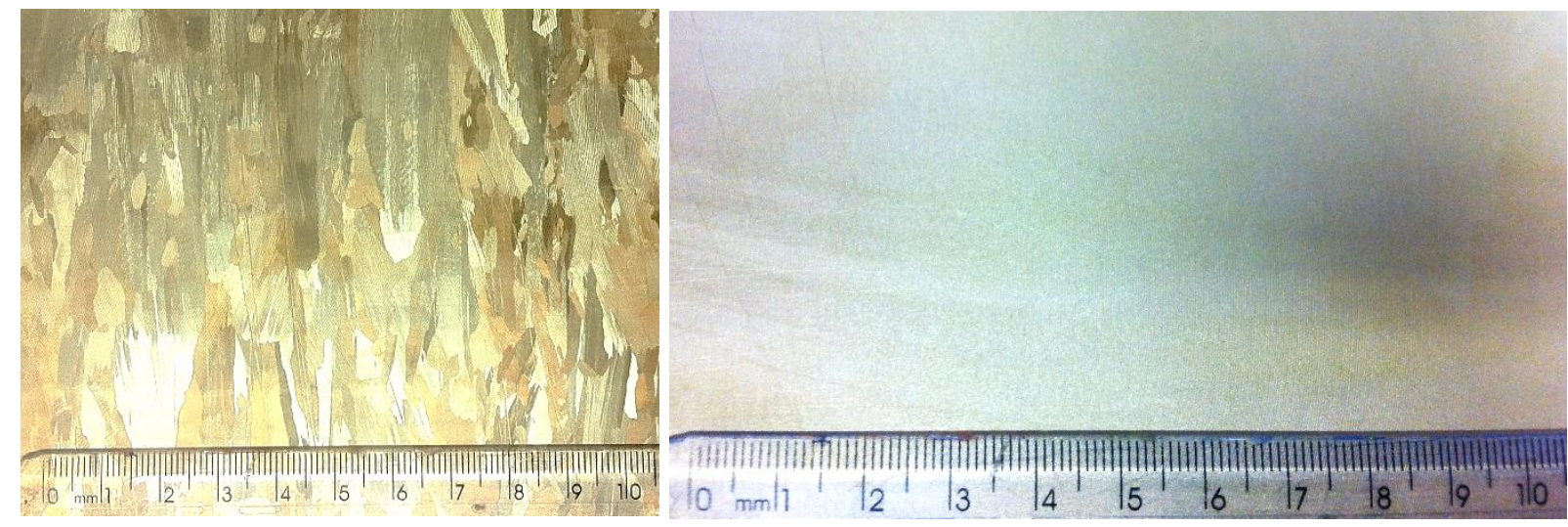

(a)

(b)

Figura 55 Macrografia da superfície das bobinas fresadas (a) Fundição contínua (F.C.) e (b) Fundição semicontínua (F.S.C.) + Laminação a quente. 
Os resultados dos tamanhos de grãos obtidos nas bobinas fresadas são apresentados na tabela 3, sendo a média de 150 grãos para o processo de fundição continua devido ao grande tamanho de grão apresentado e 450 grãos para o processo de fundição semicontínua e os desvios padrões apresentados, podendo ser notado que o processo de fundição continua apresenta um tamanho de grão médio 97,16 \% superior ao tamanho de grão médio obtido na bobina proveniente do processo de fundição semicontínua + laminação a quente, o desvio padrão do processo F.S.C. + L.Q. é 82 vezes menor que o desvio padrão detectado para o material do processo F.C., evidenciando desta forma a variação superior entre os processos. O processo de laminação a quente altera toda a estrutura bruta de fundição obtida na fabricação da placa e causa alterações microestruturais que ocorrem simultaneamente à aplicação da deformação a alta temperatura, obtendo desta forma uma estrutura de grãos homogêneos, ao contrário do processo de fundição continua que pela sua característica de extração de calor, resulta em grãos grandes e irregulares.

Tabela 3 Resultados de tamanho de grão obtidos nas bobinas fresadas.

\begin{tabular}{ccc}
\hline Característica & \multicolumn{2}{c}{ Processo de Fabricação } \\
\cline { 2 - 3 } & Fundição contínua & $\begin{array}{c}\text { Fundição semicontínua + } \\
\text { Laminação a quente }\end{array}$ \\
\hline Tamanho de Grão médio $(\mu)$ & $600 \mu \mathrm{m}$ & $17 \mu \mathrm{m}$ \\
Desvio Padrão $(\sigma)$ & $494 \mu \mathrm{m}$ & $6 \mu \mathrm{m}$ \\
\hline
\end{tabular}

Através da análise de distribuição dos dados obtidos tanto no processo de fundição contínua como no processo de fundição semicontínua + laminação a quente foi possível evidenciar através do P-Value a distribuição do tipo Gamma para o processo F.C. e distribuição do tipo Lognormal para o processo F.S.C. + L.Q.. 

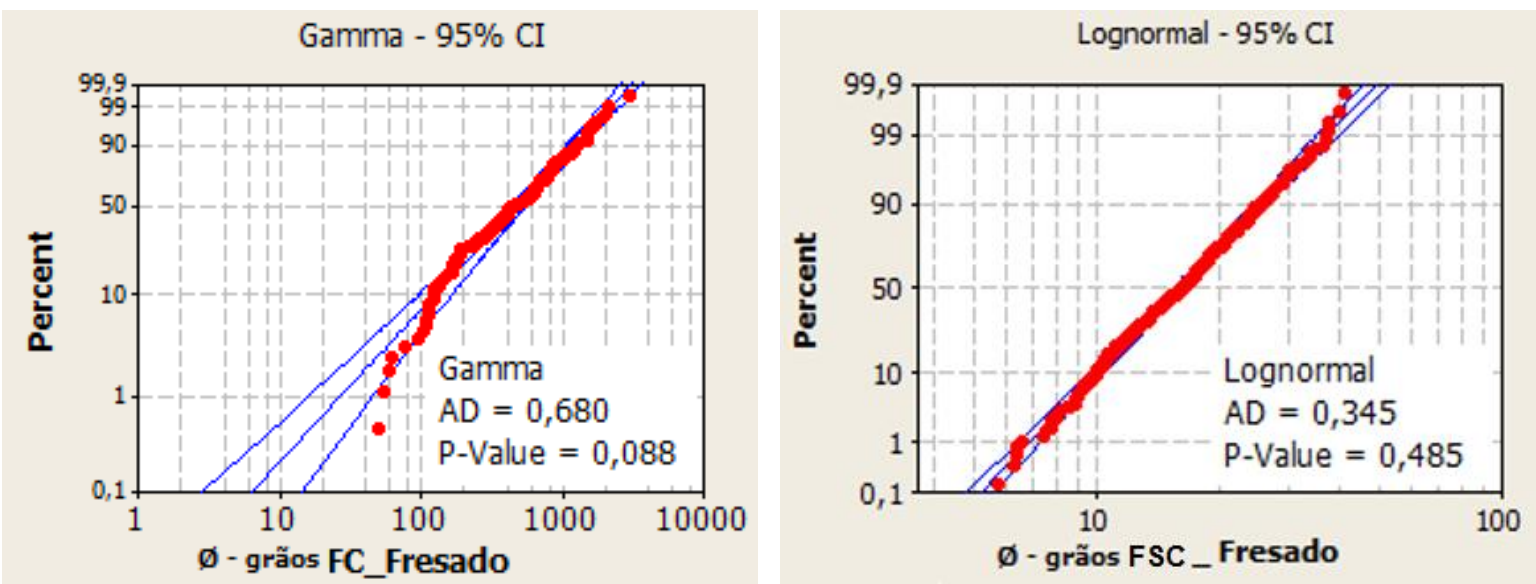

Figura 56 Distribuição dos dados de tamanho de grão para os dois processos do material fresado.

Através da Figura 56 é possível verificar que o processo F.C. apresentou um P-Value baixo, próximo do mínimo 0,05 e que os dados apresentam certa dispersão com relação às "retas" de referência (azul) de avaliação da distribuição dos dados.

Ao se obter o tipo de distribuição dos dados foi possível elaborar os histogramas com intuito de verificar graficamente a dispersão e/ou distribuição dos resultados obtidos, conforme demonstrados a seguir na Figura 57.
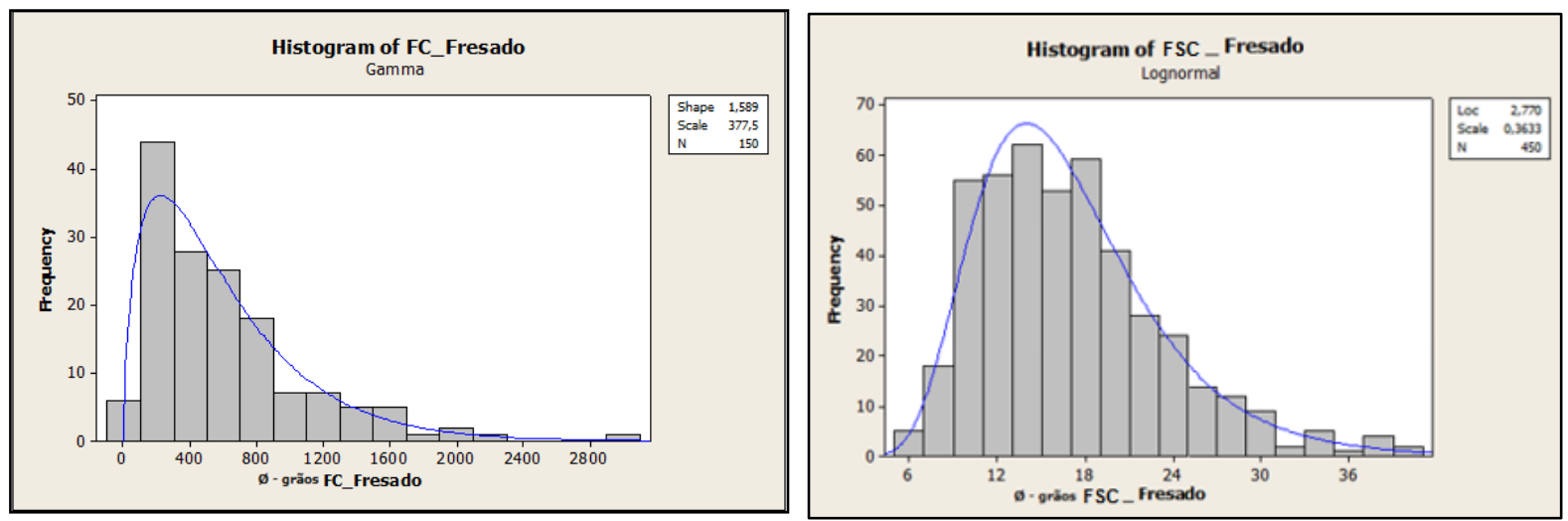

Figura 57 Histograma dos dados de tamanho de grão para os dois processos do material fresado.

O processo de fundição semicontínua + laminação a quente demonstra uma dispersão muito mais homogênea e menor quando comparada com o processo de fundição contínua, pois a variação do processo F.S.C. + L.Q. é de 6 a $41 \mu \mathrm{m}$, já a variação do processo de fundição contínua é de 50 a $2926 \mu \mathrm{m}$, essa diferença fica 
ainda mais clara através da avaliação efetuada nas micrografias, demonstradas na Figura 58.

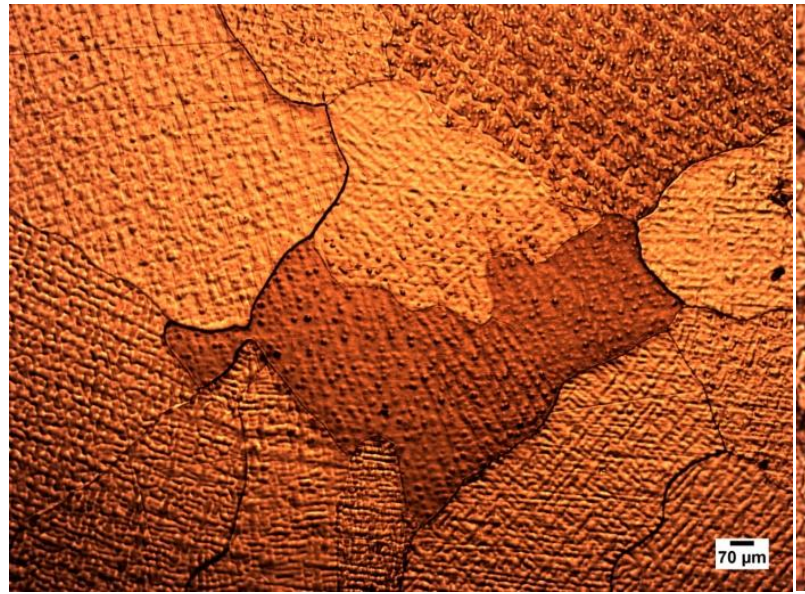

(a)

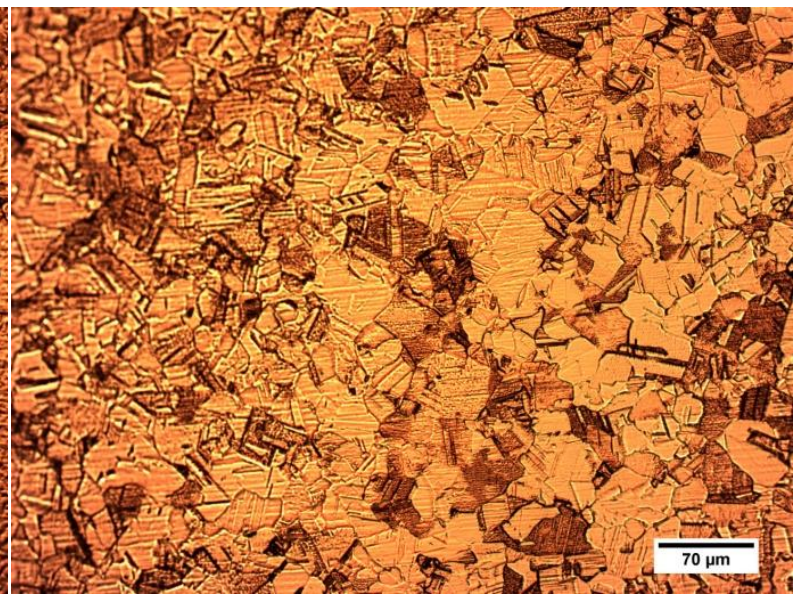

(b)

Figura 58 Micrografias (a) Processo de fundição contínua e (b) Processo de fundição semicontínua + Laminação a quente.

\subsection{Caracterização do material encruado (intermediário)}

Após a caracterização das bobinas fresadas, os materiais foram submetidos ao processo de laminação a frio intermediário, sendo imposto os $85 \%$ de redução total já citadas anteriormente, dando origem ao material em seu estado encruado. Análises metalograficas possibilitaram a visualização da deformação dos grãos, demonstrando a grande diferença entre os processos, em função é claro do tamanho de grão obtido nos materiais fresados que dão origem ao processo de laminação a frio. 


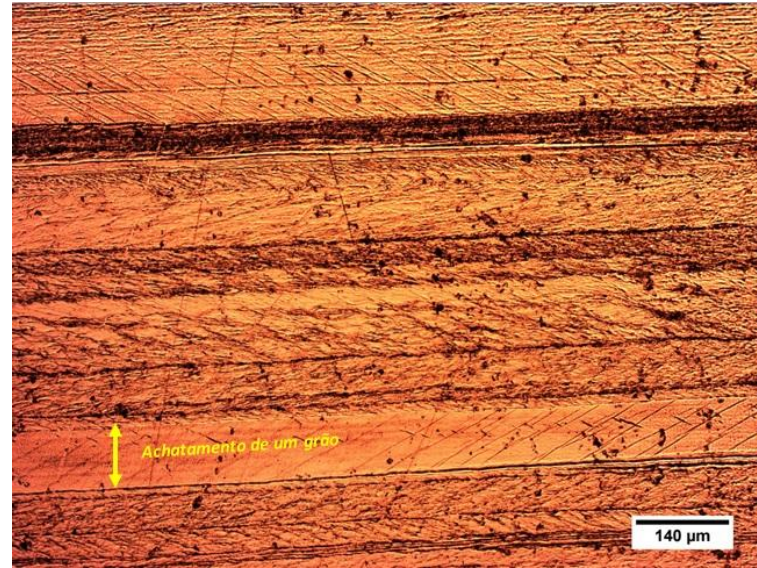

(a)

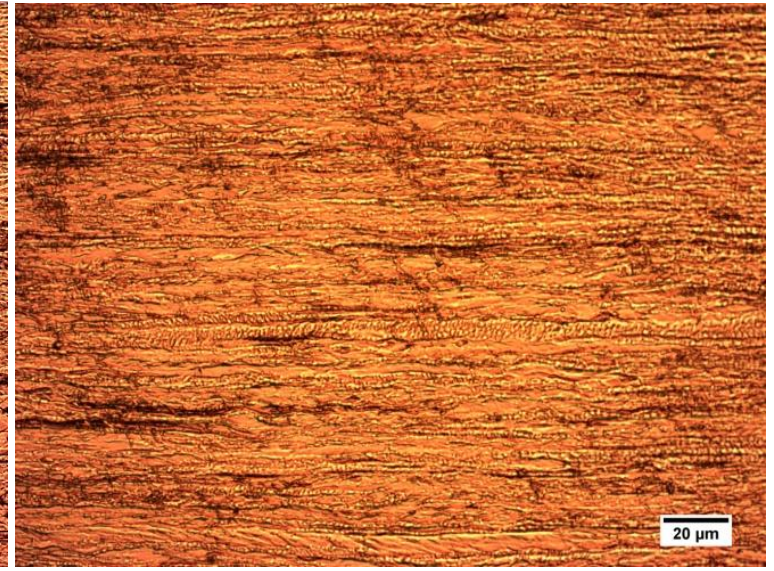

(b)

Figura 59 Micrografias (a) Processo de fundição contínua encruado e (b) Processo de fundição semicontínua + Laminação a quente encruado.

Através da avaliação das fotos expostas na Figura 59 (a) e (b) é possível notar a difrença de grãos alongados no sentido longitudinal entre os processos. Na Figura 59 (a) há o corte de grãos de fora a fora, demonstrando o "achatamento" de um grão pela seta amarela, com espessura grosseira, sendo esta evidencia decorrente da diferença do tamanho de grão incial entre os processos.

Os ensaios de limite de resistência a tração e limite de escoamento para os dois processos na espessura de 1,83 mm, após a redução de $85 \%$, são expotos na Figura 60 a seguir. Desta etapa em diante o processo de fundição semicontínua mais laminação a quente será referenciado apenas como fundição semicontínua.

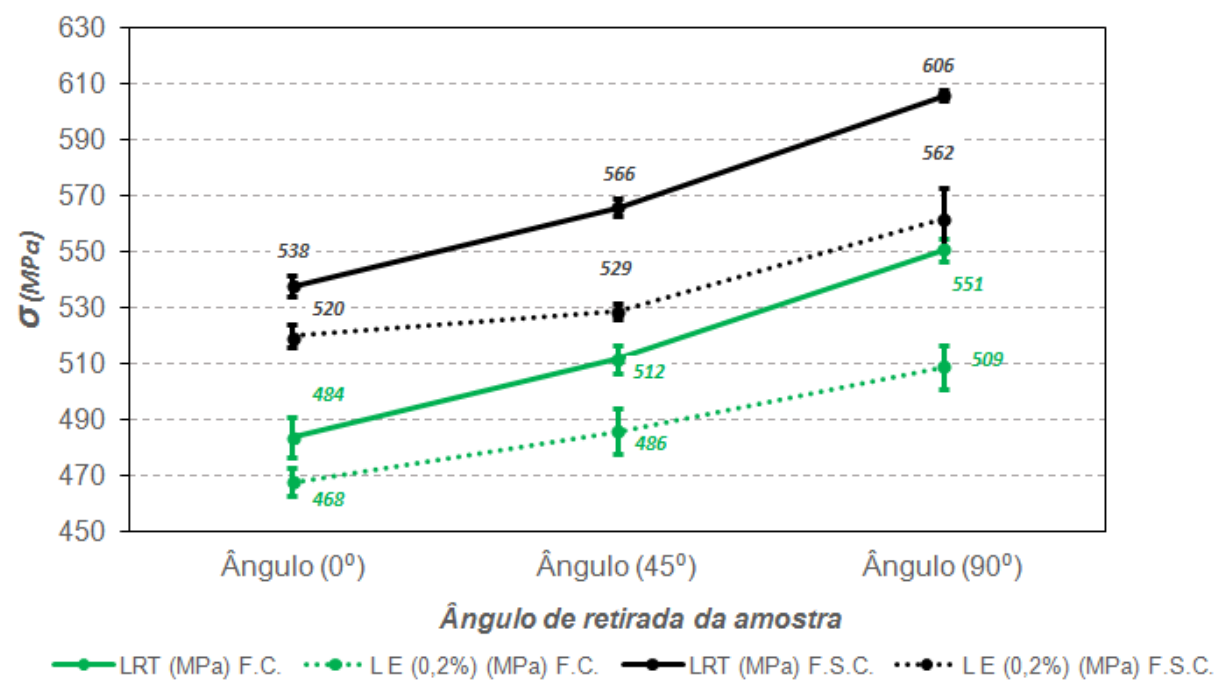

Figura 60 Resultados médios de cinco amostras das propriedades físicas do material com espessura $1,83 \mathrm{~mm}$ no estado encruado para os dois processos F.C. e F.S.C.. 


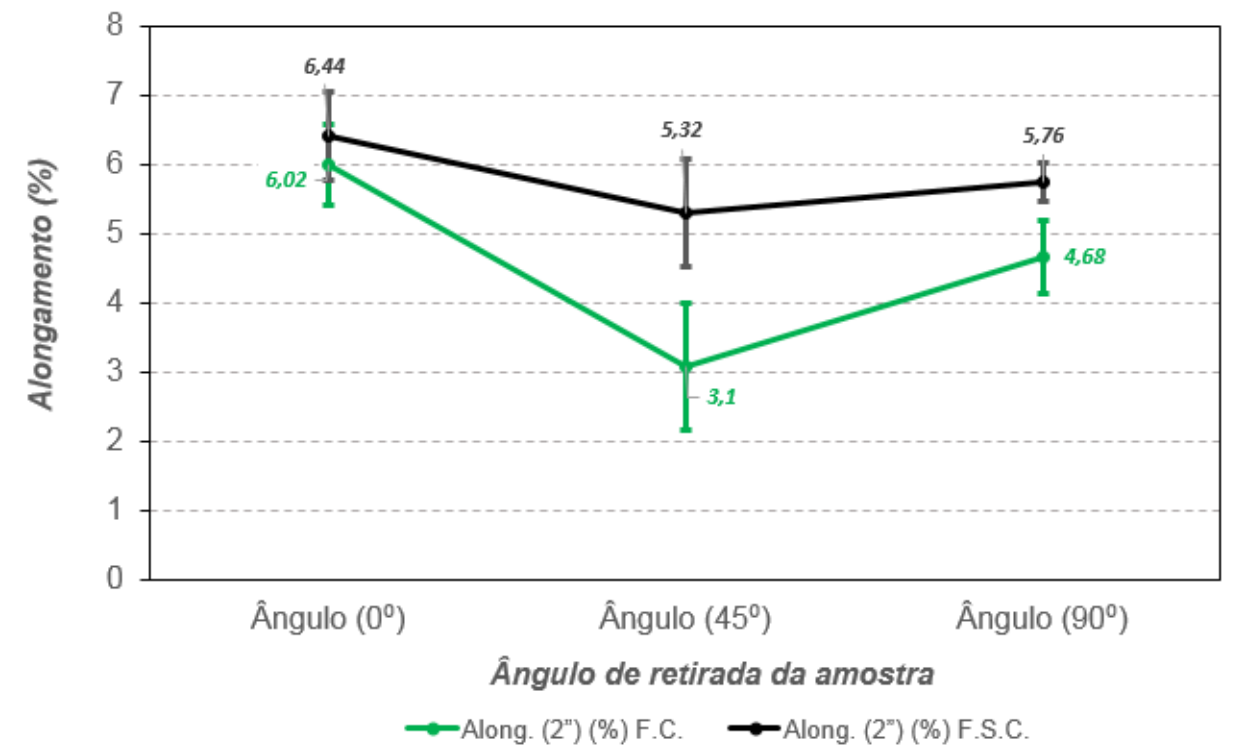

Figura 61 Resultados médios de cinco amostras de alongamento do material com espessura $1,83 \mathrm{~mm}$ no estado encruado para os dois processos F.C. e F.S.C..

Os resultados apresentados na Figura 60 demonstram uma diferença significativa do limite de resistência à tração em torno de $10 \%$ na direção $0^{\circ}$ entre os processos. Supondo a caracterização do grau de encruamento avaliado através do limite de resistência à tração alcançado, os materiais deformados igualmente pela redução de espessura (85\%), apresentaram graus de encruamento distintos em 10\%. Em ambos os processos os limites de resistência a tração apresentaram aumento do ângulo $0^{\circ}$ para $045^{\circ}$ e $90^{\circ}$. Os desvios padrões apresentados são extremamente baixos menores do que $2 \%$ dos valores obtidos o que comprova estatisticamente a consistência da obtenção dos dados. No APÊNDICE C é possível visualizar os resultados no formato de tabela.

A Figura 61 apresenta os valores de alongamento detectados para ambos os processos. Os alongamentos obtidos nos três ângulos para o processo de fundição semicontínua, apresentaram valores superiores aos apresentados pelo processo de fundição contínua, sendo essa diferença decorrente do tamanho de grão e sua homogeneidade da etapa anterior. A variação entre os ângulos é superior para o processo de fundição contínua, decorrente também do tamanho de grão e sua distribuição, em função do processo de solidificação. 
Conforme já mencionado no item Materiais e Métodos, as durezas foram efetuadas na escala Rockwell 30T (HR30T), pois as normas que regem as características a serem obtidas para o fornecimento de tiras e chapas de latão, ligas de cobre e zinco especificam essa escala dureza. A tabela 4 demonstra o resultado de dureza para espessura de $1,83 \mathrm{~mm}$ do material intermediário no estado encruado.

Tabela 4 Resultados médios de cinco amostras de dureza (HR30T) obtidos na espessura de $1,83 \mathrm{~mm}$, material intermediário no estado encruado.

\begin{tabular}{ccc}
\hline \multirow{2}{*}{ Característica } & \multicolumn{2}{c}{ Processo de Fabricação } \\
\cline { 2 - 3 } & Fundição contínua & Fundição semicontínua \\
\hline Dureza média $(\mu)$ & 73 & 75 \\
Desvio Padrão $(\sigma)$ & 1,37 & 0,35 \\
\hline
\end{tabular}

Os resultados de dureza obtidos para os processos de fundição contínua e fundição semicontínua na espessura intermediaria $(1,83 \mathrm{~mm})$, não demonstraram diferenças significativas como o limite de resistência a tração que apresentou uma diferença de $10 \%$, a dureza diferenciou-se em apenas $2,66 \%$, o desvio padrão apresentado no processo de fundição contínua é $74 \%$ superior ao detectado no processo de fundição semicontínua em função do tamanho de grão do material fresado.

\subsection{Caracterização do material mole (intermediário)}

O recozimento intermediário das bobinas foi o processo seguinte à deformação de desbaste, sendo nesta etapa realizado uma série de ensaios visando caracterizar da melhor forma possível os materiais e consecutivamente os processos, obtendo-se nesta etapa os seguintes resultados;

○ Tamanho de grão F.C. X F.S.C.

- Limite de Resistência a Tração nos ângulos $0^{\circ}, 45^{\circ}$ e $90^{\circ}$. 
- Limite de Escoamento (em 0,2\%) a $0^{\circ}, 45^{\circ}$ e $90^{\circ}$.

- Alongamento (em 2") a $0^{\circ}, 45^{\circ}$ e $90^{\circ}$.

- Ensaio de Dureza

- Os coeficientes n e K (Equação de Hollomon).

- Os coeficientes $\Delta \mathrm{r}$ e r.

○ \% Orelha.

- Ensaio Erichsen.

Os resultados de tamanho de grão obtidos nos materiais intermediários são expostos na tabela 5. As bobinas foram recozidas na mesma temperatura, porém, foi evidenciado através dos limites de resistência a tração a $0^{\circ}$ do material encruado, que o "grau de encruamento" alcançado pelos materiais se diferenciaram em 10\%, portanto, o resultado do tamanho de grão para a mesma temperatura em condições iniciais diferentes não deveria apresentar resultados similares. Burke e Tumbull (1952) propuseram as sete leis do recozimento, a segunda lei descreve que quanto menor for o grau de deformação, maior será a temperatura necessária para ocorrer à recristalização. Desta forma para a mesma condição de recozimento, o processo de fundição semicontínua iniciou o processo de recristalização mais rapidamente que o processo de fundição continua em decorrência dos $10 \%$ de diferença do limite de resistência à tração ("encruamento") já mencionada, obtendo-se um tamanho de grão superior, o que é demonstrado na tabela 5. A quinta lei proposta descreve que quanto maior for o tamanho de grão inicial, maior é a quantidade de deformação a frio necessária para que a recristalização se complete no mesmo tempo e temperatura de recozimento, demonstrando em mais uma das leis que para tamanho de grão inicial grande e/ou grosseiro se faz necessário grandes reduções para a obtenção de uma recristalização completa.

Tabela 5 Resultados de tamanho de grão médios obtidos nas bobinas intermediárias (Após $85 \%$ de redução de espessura e recozimento), espessura de $1,83 \mathrm{~mm}$.

Característica

Processo de Fabricação

Fundição contínua

$15 \mu \mathrm{m}$

$6 \mu \mathrm{m}$
Tamanho de Grão médio $(\mu)$

Desvio Padrão ( $\sigma$ )
Fundição semicontínua 
As distribuições dos dados de tamanho de grão dos materiais intermediários no estado recozido, também foram verificadas, apresentando uma distribuição do tipo Weibull para o processo F.C. e uma distribuição do tipo Lognormal para o processo F.S.C. (vide Figura 62). Essas distribuições se mantiveram as mesmas com relação às etapas anteriores, pois no material fresado detectou-se as mesmas distribuições para os processos.
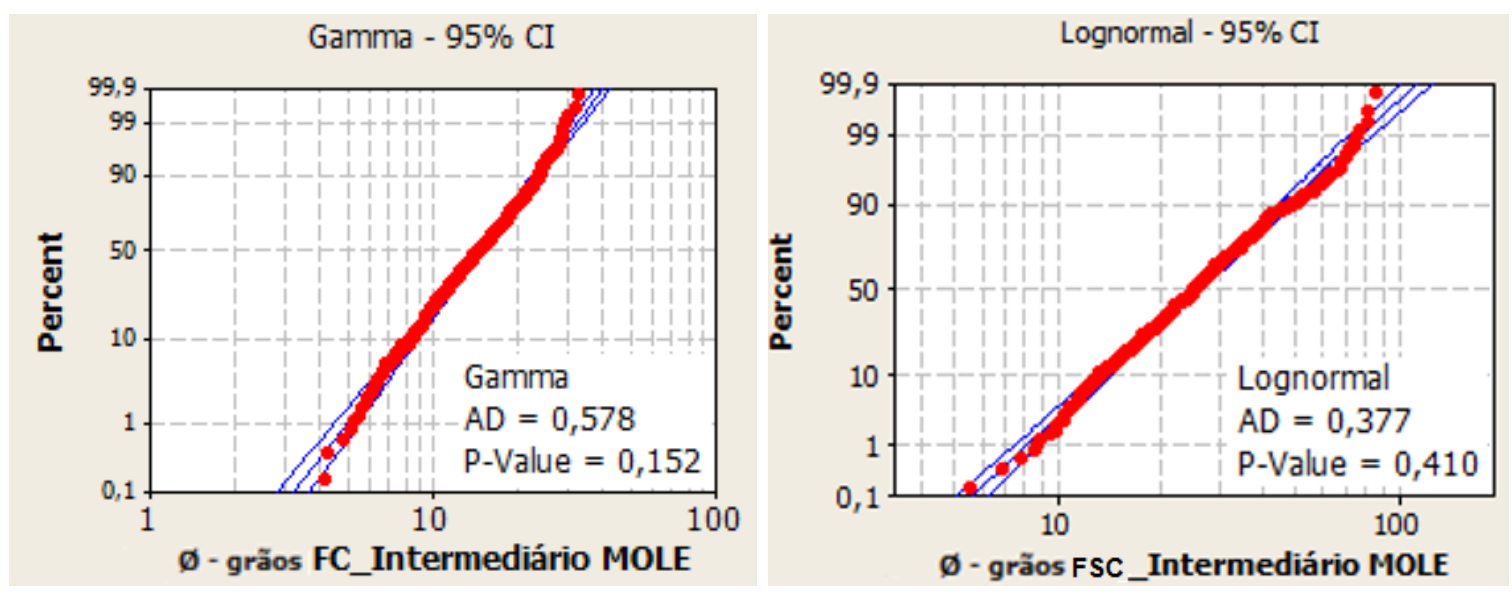

Figura 62 Distribuição dos dados de tamanho de grão para os dois processos, materiais intermediários moles.

Outra forma de avaliar a distribuição dos dados é visual e efetuada atráves da elaboração dos histogramas para cada tipo de distribuição obtida, conforme a Figura 63, cuja demonstração é efetuada separadamente e em conjunto, sendo possivel verificar a dispersão dos dados.

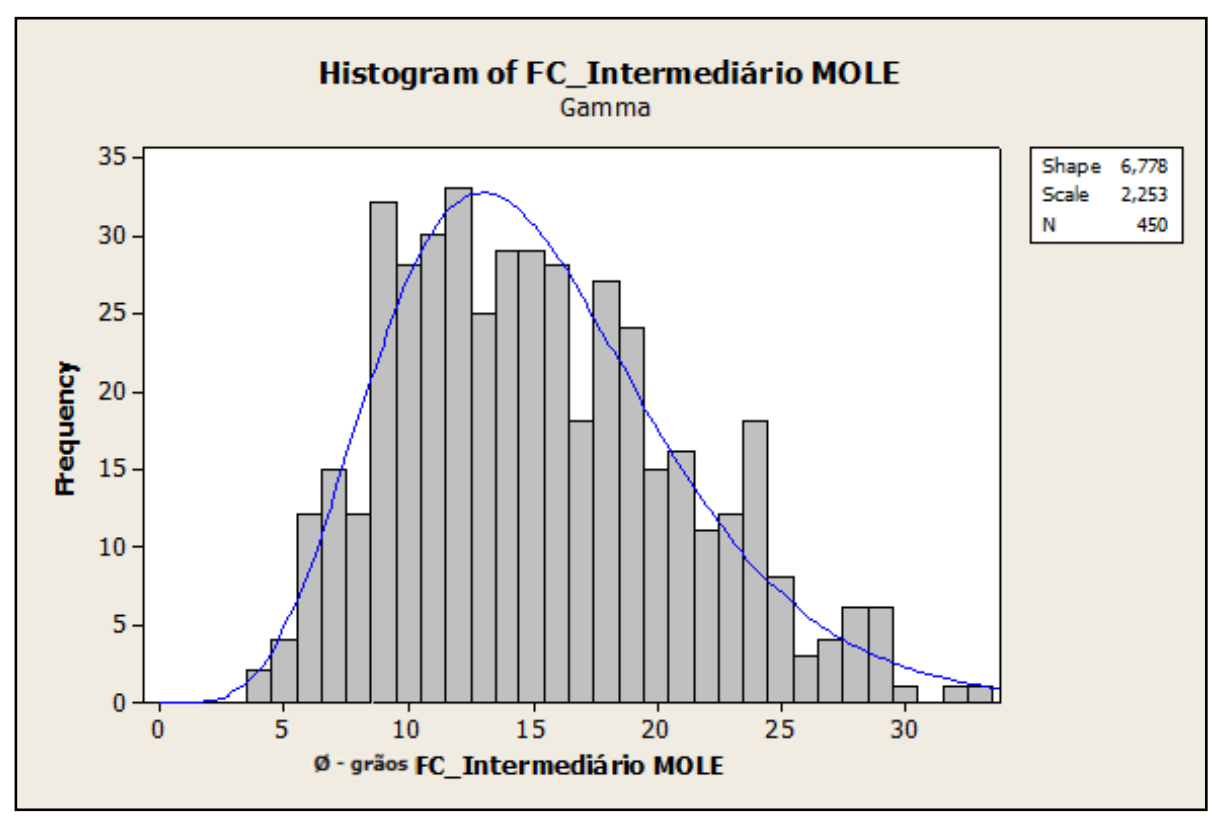



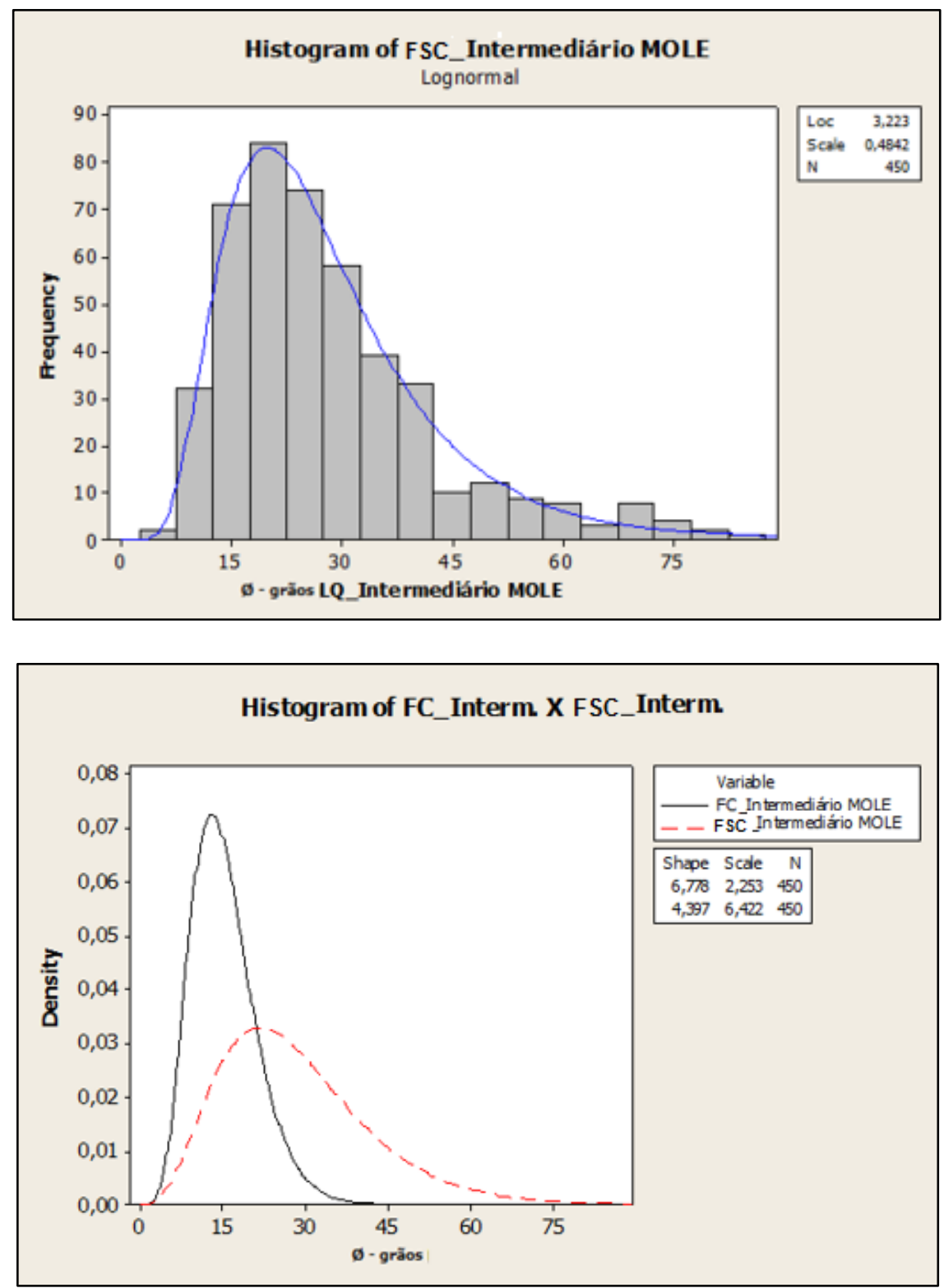

Figura 63 Histogramas do tamanho de grão dos processos de fundição contínua e de fundição semicontínua nos materiais intermediários.

Após o tratamento térmico realizado nos materiais intermediário os resultados obtidos se inverteram com relação ao tamanho de grão médio obtido e consecutivamente a dispersão dos dados. Os histogramas da Figura 63, nos permitem verificar uma variação superior detectada no processo de fundição semicontínua, de 6 a $86 \mu \mathrm{m}$ com uma média também superior de $28 \mu \mathrm{m}$, sendo esta maior variação decorrente do tamanho de grão médio, ou seja, quanto maior for o tamanho de grão médio, maior será a variação dos tamanhos de grãos presentes no material. As micrografias a seguir demonstram essa maior variação, vide Figura 64. 


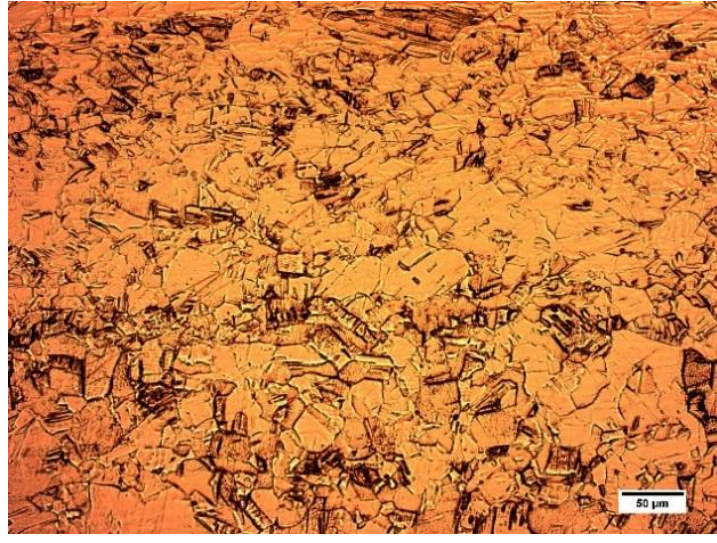

(a)

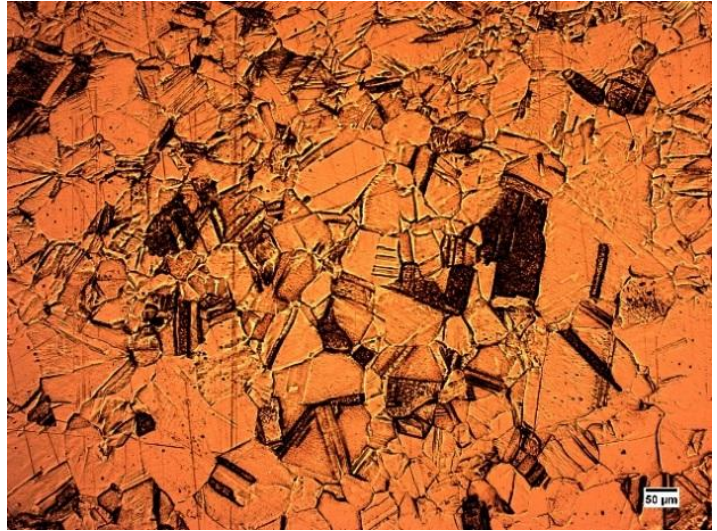

(b)

Figura 64 Micrografias (a) Processo de fundição contínua e (b) Processo de fundição semicontínua materiais intermediários.

Apesar dos materiais apresentarem uma diferença de 10\% no limite de resistência a tração do material encruado e uma diferença significativa no tamanho de grão de 46,0 \%, nas propriedades mecânicas a diferença apresentada no limite de resistência a tração a $0^{\circ}$ é apenas de $4,27 \%$, com desvios padrões baixos, mostrando a consistência dos dados obtidos e apresentados na Figura 65. No APÊNDICE D, é possível visualizar os dados no formato de tabela com os respectivos desvios padrões detectados.

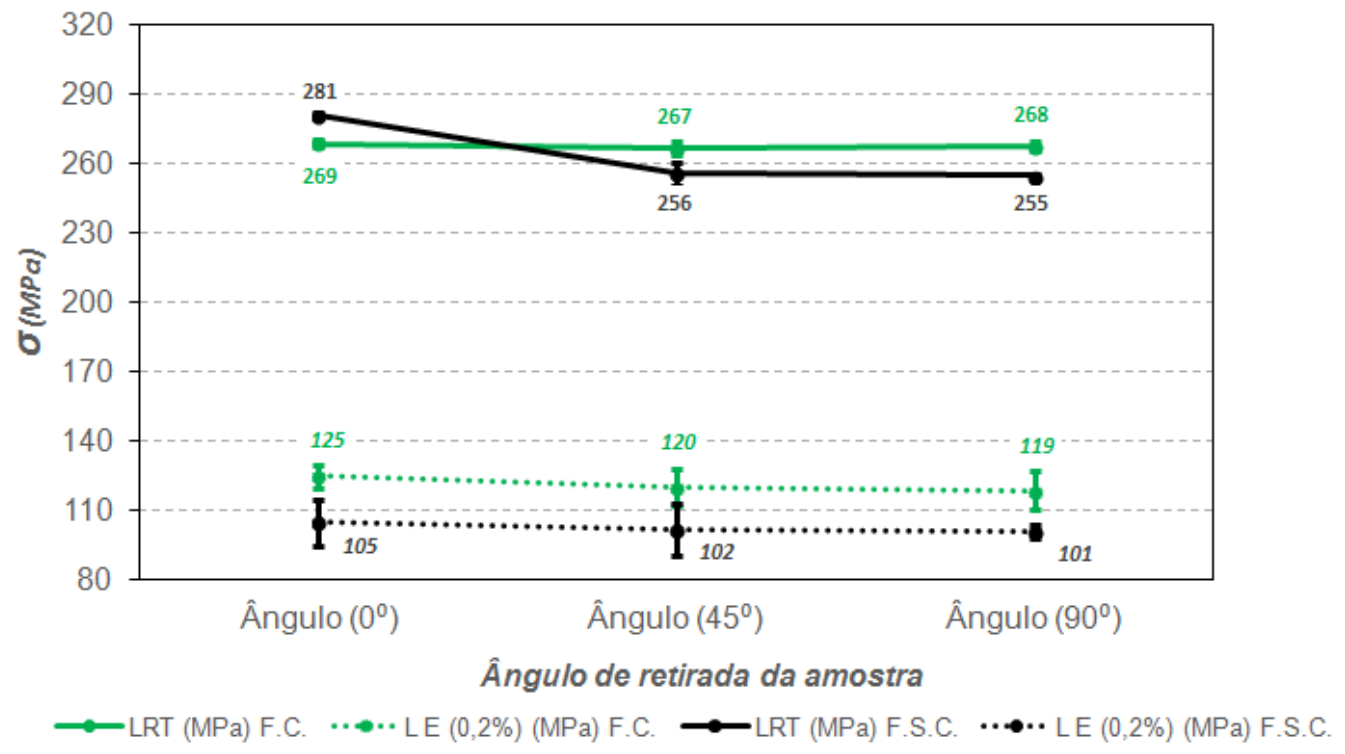

Figura 65 Resultados médios das propriedades físicas do material com espessura 1,83 mm no estado recozido para os dois processos F.C. e F.S.C.. 


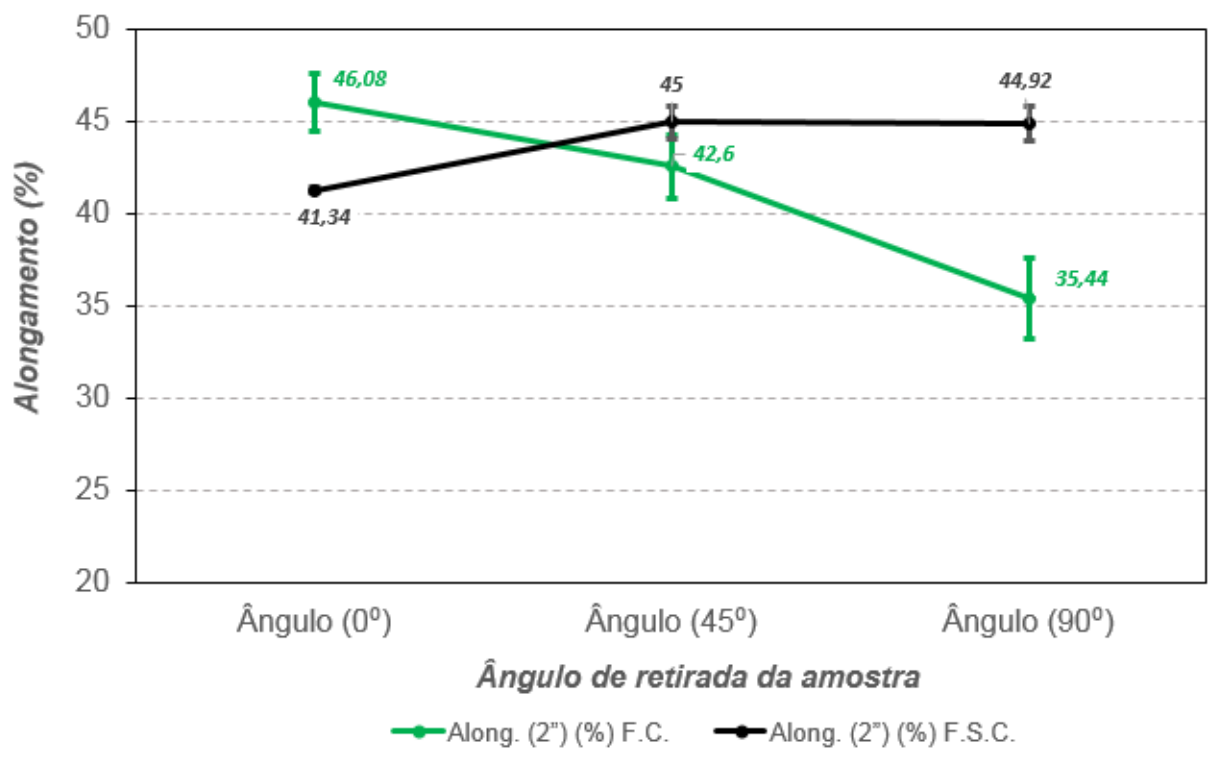

Figura 66 Resultados médios de alongamento do material com espessura 1,83 mm no estado recozido para os dois processos F.C. e F.S.C..

Os valores de limite de resistência à tração para o processo de fundição contínua apresentam-se praticamente estáveis nos três ângulos, diferenciando-se apenas por $2 \mathrm{MPa}$, já o processo de fundição semicontínua apresenta até $26 \mathrm{MPa}$ (vide Figura 65), evidenciando desta forma um material anisotrópico com diferença de propriedades mecânicas entre os ângulos no plano da chapa, podendo ser comprovado no processo de estampagem a formação indesejável de "orelha" item que será confirmado a seguir nos resultados apresentados de $\Delta r$ e do próprio ensaio de "orelha".

Os alongamentos obtidos para o processo de fundição continua, apresentaram-se decrescentes do ângulo 0 até $090^{\circ}$, com variações duas vezes superiores aos alongamentos alcançados no processo de fundição semicontínua.

Os resultados de dureza detectadas para o material intermediário no estado recozido são expostos na tabela 6 , sendo possível verificar uma diferença significativa entre os processos de $32,7 \%$ e desvios padrões em torno de 11,48 e $9,50 \%$. O aumento do desvio padrão se deve ao fato do material se encontrar no estado recozido, pois, materiais moles tendem a apresentar uma variação de dureza superior, o que será confirmado na espessura acabada também. 
Tabela 6 Resultados médios de dureza (HR30T) obtidas na espessura de 1,83 mm, material intermediário mole.

\begin{tabular}{ccc}
\hline \multirow{2}{*}{ Característica } & \multicolumn{2}{c}{ Processo de Fabricação } \\
\cline { 2 - 3 } & Fundição contínua & Fundição semicontínua \\
\hline Dureza média $(\mu)$ & 22,0 & 14,8 \\
Desvio Padrão $(\sigma)$ & 2,1 & 1,7 \\
\hline
\end{tabular}

A pequena diferença detectada no limite de resistência a tração entre os processos de fabricação de $4,27 \%$ é muito inferior à diferença obtida na dureza e no tamanho de grão dos materiais, desta forma pode-se verificar que os resultados de dureza são mais representativos com relação ao tamanho de grão do que ao limite de resistência a tração detectado.

Os coeficientes de encruamento $n$ e o coeficiente de resistência $K$ são também itens importantes para o processo de estampagem de chapas, demonstrando a capacidade ou habilidade do material em distribuir a deformação uniformemente na presença de um gradiente de tensões (n) e o nível de resistência que o material suporta ao ser deformado na estampagem e/ou processos similares (K), desta forma julgou-se coerente a determinação destes índices mesmo que no material intermediário conforme a Figura 67.

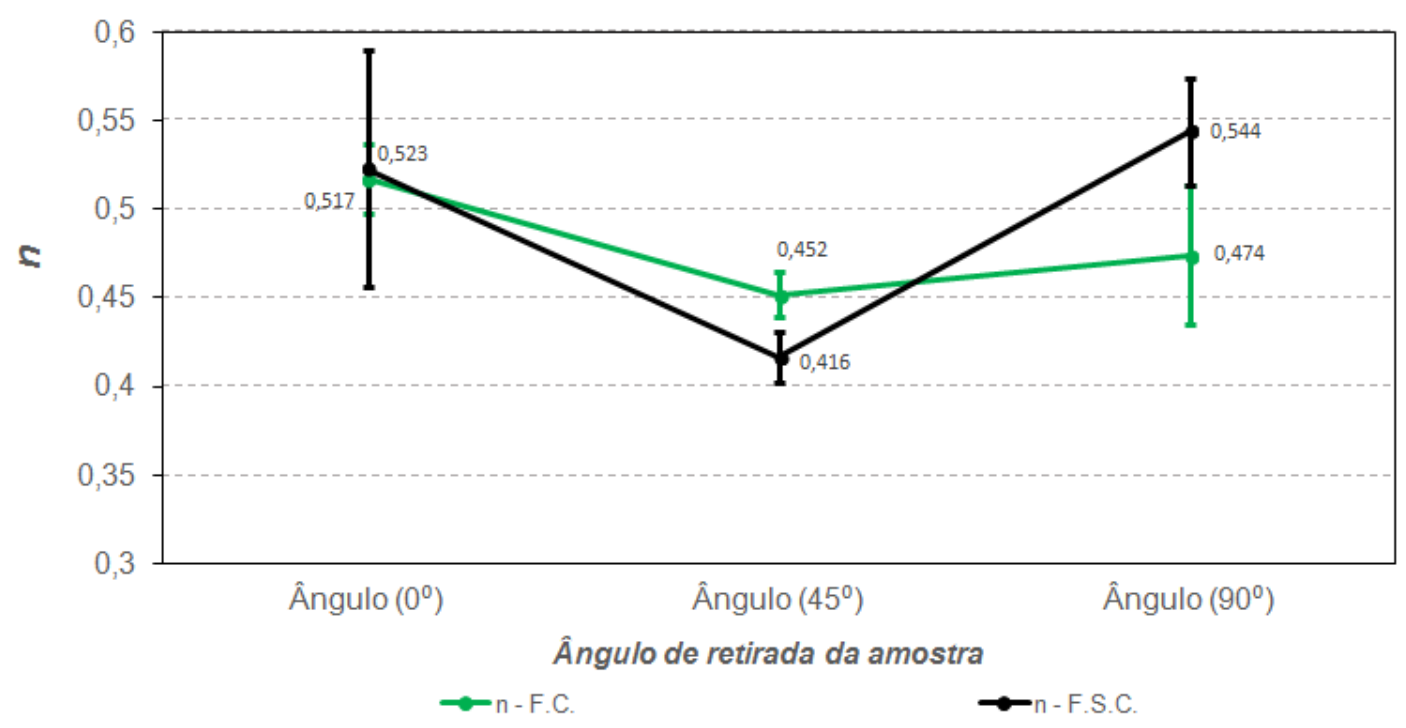

Figura 67 Resultados médios dos coeficientes de encruamento (n) do material com espessura $1,83 \mathrm{~mm}$ no estado recozido para os dois processos F.C. e F.S.C.. 
Os valores dos coeficientes de encruamento $\mathrm{n}$ médios apresentados na Figura 67 são similares a $0^{\circ}$, apesar do desvio padrão apresentado no processo de fundição semicontínua ser grande, quando comparado com o outro desvio padrão, em torno de $13 \%$ (F.S.C.) sobre o valor de $\mathrm{n}$ obtido, contra $4 \%$ (F.C.). Os coeficientes obtidos a $45^{\circ}$ para o processo F.C. apresentaram um valor médio levemente superior em torno de 7,96\% quando comparado ao processo de F.S.C. e com desvios padrões distintos e pequenos, sem se "entrelaçar", o que pode comprovar efetivamente a diferença entre os valores. A $90^{\circ}$ o processo de fundição contínua apresenta um valor inferior em torno de $12,86 \%$, porém, com desvios padrões "entrelaçados", demonstrando maior variação na detecção dos dados. Os dados em formato de tabela se encontra no APÊNDICE E.

Stachowicz (1989) demonstra em seu estudo realizado com o latão $85 \%$ de cobre e $15 \%$ de zinco, resultados para o coeficiente de encruamento a 0,45 e $90^{\circ}$, sendo possível verificar a influência do tamanho de grão na obtenção dos coeficientes, quanto maior o tamanho de grão maior é o valor obtido de $\mathrm{n}$, para o tamanho de grão $41,80 \mu \mathrm{m}$ obteve-se n para $0^{\circ}$ de $0,451,45^{\circ}$ de 0,460 e para $90^{\circ}$ de 0,482 . Para o tamanho de grão $78,60 \mu \mathrm{m}$ obteve-se $\mathrm{n}$ a $0^{\circ}$ de 0,524 , a $45^{\circ}$ de 0,506 e a $90^{\circ}$ de 0,510 , sendo possível verificar que não existe correlação com os ângulos, assim como existe com o tamanho de grão.

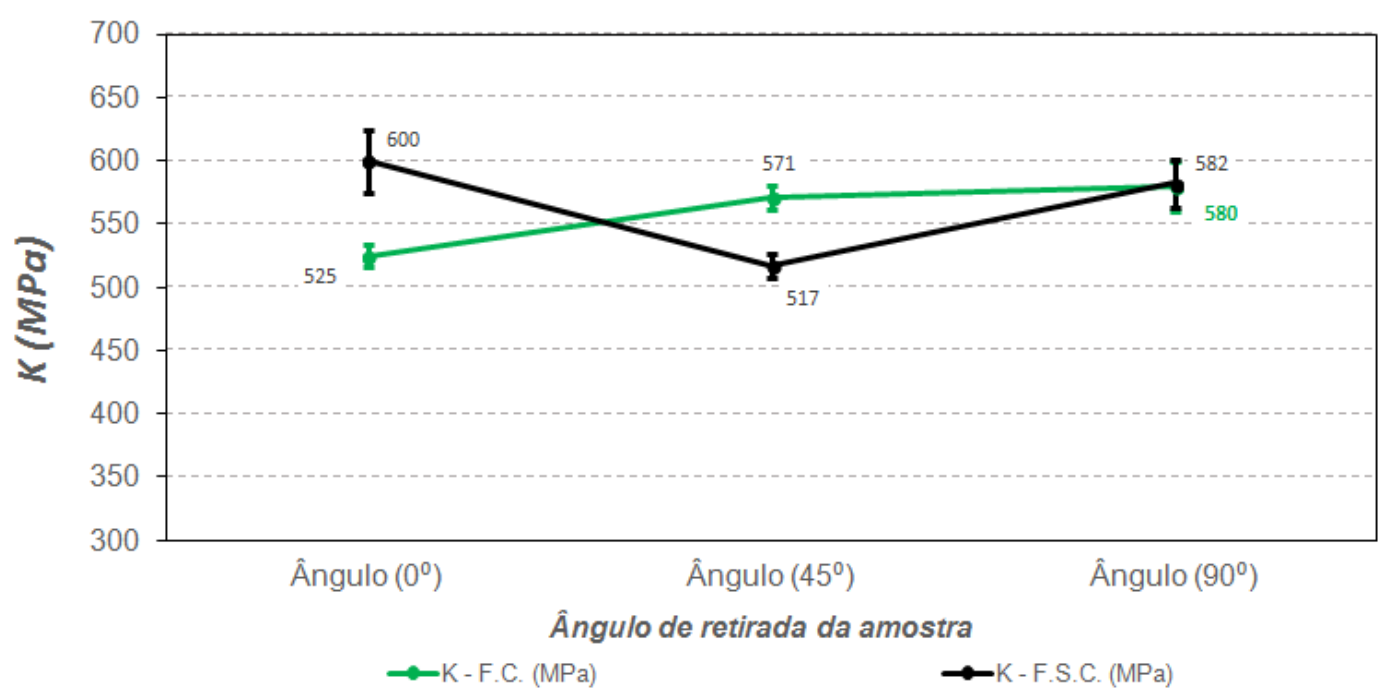

Figura 68 Resultados médios dos coeficientes de resistência $(K)$ do material com espessura $1,83 \mathrm{~mm}$ no estado recozido para os dois processos F.C. e F.S.C.. 
Os coeficientes de resistência $\mathrm{K}$ apresentaram valores bem diferentes a $0^{\circ} \mathrm{em}$ torno de 12,5 \% (vide Figura 68), tanto o desvio padrão de n como o do K para o processo de fundição semicontínua são decorrentes dos desvios padrões detectados na obtenção dos limites de escoamento do material mole intermediário, pois o $\mathrm{n}$ e K são obtidos apenas com os dados da zona plástica, ou seja, dados do limite de escoamento ao limite de resistência a tração, sendo possível verificar um desvio padrão de $9,5 \%$ para o material a $0^{\circ}$ do processo de fundição semicontínua. Os valores de $\mathrm{K}$ detectados a $45^{\circ}$ também apresentaram uma diferença significativa em torno de 9,45 \%, porém, o maior valor encontrado passou a ser para o processo de fundição contínua. A $90^{\circ}$ detectou-se valores com uma diferença inferior a 0,5\%, ou seja, valores iguais com desvio padrão também iguais diferenciando apenas em $1 \mathrm{MPa}$.

Assim como o coeficiente de encruamento (n) Stachowicz (1989) demonstra o coeficiente de resistência $(K)$ para o latão $85 \%$ de cobre e $15 \%$ zinco nos três ângulos, 0, 45 e $90^{\circ}$ e os valores detectados a $0^{\circ}$, foram os que apresentaram maiores valores, diferentemente dos evidenciados na Figura 68, cujo processo de fundição continua se obteve o menor valor no ângulo $0^{\circ}$.

Tabela 7 Resultados dos coeficientes de anisotropia planar $\Delta \mathrm{r}$ e anisotropia normal $r$ do material intermediário (1,83 mm), (a) fundição contínua e (b) fundição semicontínua.

\begin{tabular}{|c|c|c|c|c|}
\hline Ângulo & $\mathrm{R}$ & $\mathrm{R} \mu$ & $r_{\text {NORMAL }}$ & $\Delta r$ \\
\hline \multirow{5}{*}{$0^{\circ}$} & 1,07 & \multirow{5}{*}{1,12} & \multirow{15}{*}{0,85} & \multirow{15}{*}{0,06} \\
\hline & 1,17 & & & \\
\hline & 1,00 & & & \\
\hline & 1,24 & & & \\
\hline & 1,15 & & & \\
\hline \multirow{5}{*}{$45^{\circ}$} & 0,89 & \multirow{5}{*}{0,82} & & \\
\hline & 0,69 & & & \\
\hline & 0,88 & & & \\
\hline & 0,80 & & & \\
\hline & 0,78 & & & \\
\hline \multirow{5}{*}{$90^{\circ}$} & 0,68 & \multirow{5}{*}{0,63} & & \\
\hline & 0,57 & & & \\
\hline & 0,63 & & & \\
\hline & 0,65 & & & \\
\hline & 0,68 & & & \\
\hline
\end{tabular}

\begin{tabular}{|c|c|c|c|c|}
\hline Ângulo & $\mathrm{R}$ & $\mathrm{R} \mu$ & $r_{\text {NORMAL }}$ & $\Delta r$ \\
\hline \multirow{5}{*}{$0^{\circ}$} & 1,06 & \multirow{5}{*}{1,01} & \multirow{15}{*}{1,05} & \multirow{15}{*}{$-0,40$} \\
\hline & 0,98 & & & \\
\hline & 1,07 & & & \\
\hline & 0,99 & & & \\
\hline & 0,97 & & & \\
\hline \multirow{5}{*}{$45^{\circ}$} & 1,21 & & & \\
\hline & 1,28 & & & \\
\hline & 1,27 & 1,25 & & \\
\hline & 1,30 & & & \\
\hline & 1,19 & & & \\
\hline \multirow{5}{*}{$90^{\circ}$} & 0,64 & \multirow{5}{*}{0,68} & & \\
\hline & 0,66 & & & \\
\hline & 0,69 & & & \\
\hline & 0,73 & & & \\
\hline & 0,67 & & & \\
\hline
\end{tabular}

(a)

(b) 
A determinação dos coeficientes de anisotropia planar $\Delta \mathrm{r}$ e anisotropia normal $r$ são efetuadas com bastante frequência nas indústrias de estampagem e nas usinas fabricantes de tiras e chapas, pois determinam a possível formação de "orelha" e o possível afinamento da chapa durante o processo de conformação, portanto, são índices que auxiliam na prevenção de defeitos durante o processo de fabricação de peças principalmente em repuxos profundos, esses índices indicam a presença ou ausência de textura, provenientes dos processos de fabricação conforme referenciado na revisão bibliográfica deste trabalho, se a chapa apresentar os grãos com orientação ao acaso, será isotrópica e consecutivamente possuirá valores de $r \cong 1$ e $\Delta r \cong 0$ (BRESCIANI, SILVA, BATALHA e BUTTON, 2011), sendo assim o processo de fundição continua pode ser considerado como um material isotrópico, ao contrário do material proveniente do processo de fundição semicontínua, o qual possui um valor de $\Delta r=-0,40$ indicando certo índice de textura e consecutivamente a presença de "orelha" a ser confirmada nos resultados a seguir.

Tabela 8 Resultados dos ensaios de "orelha", material intermediário mole (1,83 mm).

\begin{tabular}{ccc}
\hline Características & \multicolumn{2}{c}{ Processos de Fabricação } \\
\cline { 2 - 3 } & Fundição continua & Fundição semicontínua \\
\hline \% Orelha & 0,85 & 2,83 \\
(Desvio Padrão) & $(0,77)$ & $(0,38)$ \\
\hline
\end{tabular}

Os resultados apresentados na tabela 8 confirmam as afirmações efetuadas até aqui, a formação de "orelha" na espessura do material intermediário para o processo de fundição semicontínua, devido ao resultado de $\Delta \mathrm{r}$ constatado e agora confirmado através da \% de Orelha obtida.

Conforme analisado anteriormente o material proveniente do processo de fundição continua apresentou uma granulação superior no material fresado e consecutivamente um limite de resistência à tração inferior ao ser laminado a frio, ou seja, os materiais sofreram o mesmo grau de redução de espessura, porém, o grau de encruamento obtido foi inferior no processo de fundição contínua, o que pode ter 
gerado uma textura com menor intensidade do que no processo de fundição semicontínua.

O ensaio Erichsen item de controle nas indústrias da estampagem e usinas fabricantes de chapas foi também um ensaio realizado para caracterizar o material intermediário objetivando avaliar diferenças entres os materiais, visto que o processo inicial possui características distintas, segue abaixo a tabela $9 \mathrm{com}$ os resultados dos ensaios efetuados nas espessuras intermediarias de 1,83 $\mathrm{mm}$.

Tabela 9 Resultados dos ensaios Erichsen, material intermediário mole.

\begin{tabular}{cc}
\hline Processos de Fabricação & Índice Erichsen (mm) \\
\hline Fundição Contínua & 16,65 \\
(Desvio Padrão) & $(0,10)$ \\
\hline Fundição Semicontínua & 17,57 \\
(Desvio Padrão) & $(0,49)$ \\
\hline
\end{tabular}

A tabela 9 nos permite avaliar uma diferença de 5,2 \% entre os resultados obtidos nos ensaios Erichsen, apresentando o maior resultado para o processo de fundição semicontínua, o que já era de se esperar, pois este processo apresentou um tamanho de grão superior e o ensaio Erichsen é correlacionável fortemente com o tamanho de grão presente na tira ou chapa avaliada.

\subsection{Caracterização do material encruado (acabado)}

Após a caracterização do material intermediário repetiu-se toda a caracterização para o material acabado encruado, obtendo os resultados de propriedades mecânicas nos três sentidos $0^{\circ}, 45^{\circ}$ e $90^{\circ}$, conforme as Figura 69 e 70 a seguir. 


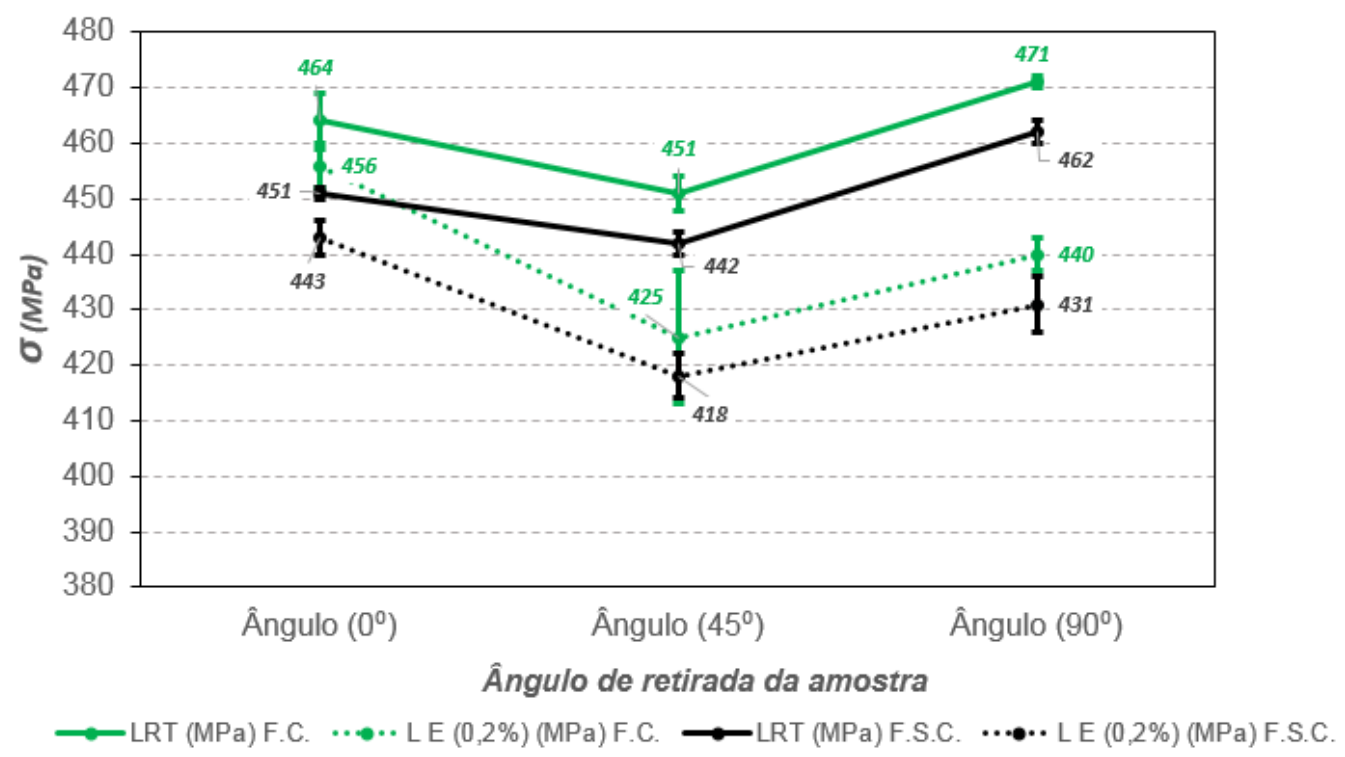

Figura 69 Resultados médios das propriedades físicas do material com espessura 1,10 mm no estado encruado para os dois processos F.C. e F.S.C..

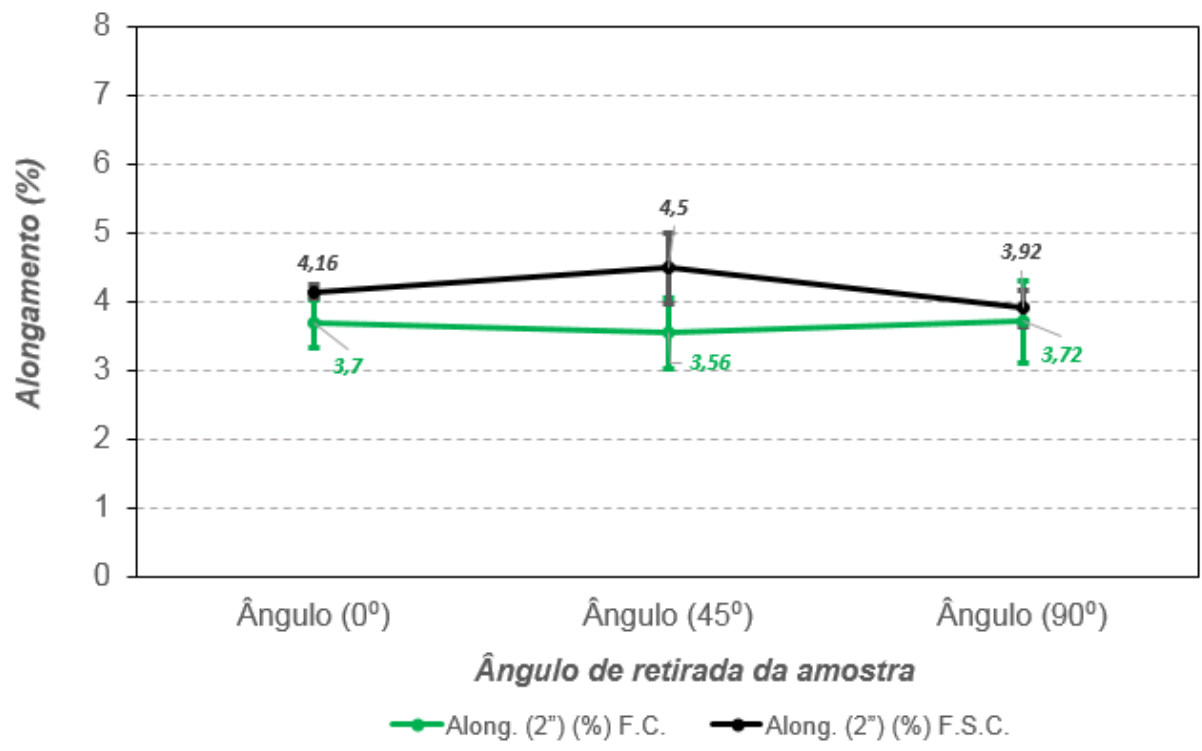

Figura 70 Resultados médios do alongamento do material com espessura 1,10 mm no estado encruado para os dois processos F.C. e F.S.C..

Apesar do tamanho de grão do material intermediário apresentar uma diferença significativa entre os processos de 46,0 \%, após o processo de laminação de acabamento impondo ao material uma redução de espessura de $40 \%$, os limites de resistência à tração obtidos apresentaram uma diferença insignificante de 2,80 \% na direção $0^{\circ}$, demonstrando que o tamanho de grão pouco influenciou no "grau de 
encruamento" avaliado através do limite de resistência à tração, já o alongamento apresentou acréscimo variando de 5,10 a $21 \%$ entre os ângulos de $0^{\circ}, 45^{\circ}$ e $90^{\circ}$ para os materiais provenientes do processo de fundição semicontínua. No APÊNDICE F é possível visualizar os dados no formato de tabela.

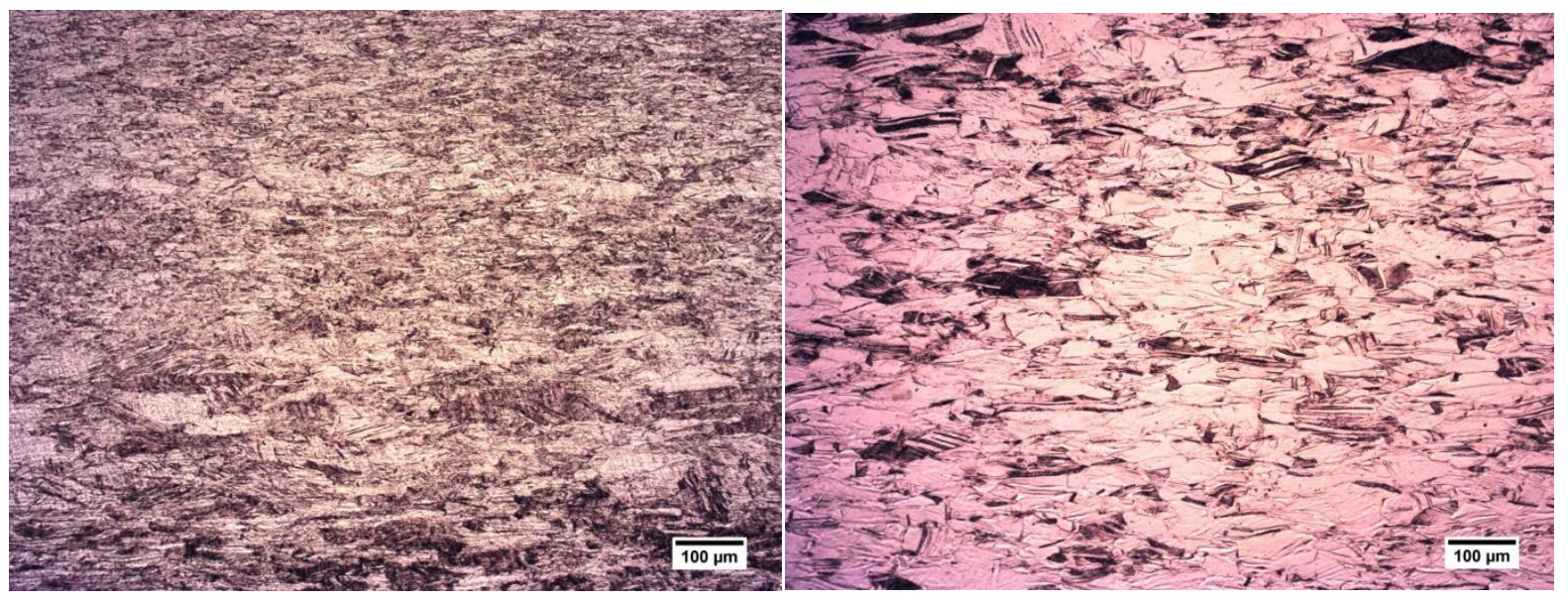

Figura 71 Micrografias (a) Processo de fundição contínua e (b) Processo de fundição semicontínua materiais acabados encruados.

Através das microestruturas apresentadas acima na Figura 71 é possível verificar a deformação causada nos grãos do material intermediário, sendo $15 \mu \mathrm{m}$ para o processo F.C. e $28 \mu \mathrm{m}$ para o processo F.S.C., evidenciando um "achatamento" superior para os grão do material proveniente do processo F.S.C. que resultou no material intermediário um tamanho de grão superior em $46 \%$.

A tabela 10 demonstra os resultados de dureza obtidos no material de espessura de $1,10 \mathrm{~mm}$ no estado encruado.

Tabela 10 Resultados médios de dureza (HR30T) obtidos na espessura de 1,10 mm, material acabdo no estado encruado.

\begin{tabular}{ccc}
\hline \multirow{2}{*}{ Característica } & \multicolumn{2}{c}{ Processo de Fabricação } \\
\cline { 2 - 3 } & 70 & Fundição semicontínua \\
\hline Dureza média $(\mu)$ & 0,71 & 68,8 \\
Desvio Padrão $(\sigma)$ & 0,84 \\
\hline
\end{tabular}


Os resultados de dureza obtidos para os processos de fundição contínua e fundição semicontínua na espessura acabada $(1,10 \mathrm{~mm})$ encruada, não demonstraram diferenças significativas, não ultrapassando $1,71 \%$ e os desvios padrões se mantiveram bem próximos.

\subsection{Caracterização do material mole (acabado)}

Assim como na etapa intermediária de fabricação das chapas efetuou-se a caracterização das principais propriedades do material acabado para os dois processos, conforme a seguir;

- Tamanho de grão F.C. X F.S.C.

- Limite de Resistência a Tração nos ângulos $0^{\circ}, 45^{\circ}$ e $90^{\circ}$

- Limite de Escoamento (em 0,2\%) a $0^{\circ}, 45^{\circ}$ e $90^{\circ}$

$\circ$ Alongamento (em 2") a $0^{\circ}, 45^{\circ}$ e $90^{\circ}$

- Ensaio de Dureza

- Os coeficientes n e K (Equação de Hollomon)

- Os coeficientes $\Delta \mathrm{r}$ e r

○ \% Orelha

- Ensaio Erichsen

Assim como na etapa anterior do material intermediário mole, o material acabado recozido foi caracterizado através dos ensaios listados acima e consecutivamente obteve-se os resultados apresentados a seguir.

Tabela 11 Resultados médios dos tamanhos de grãos obtidos nas bobinas acabadas.

\begin{tabular}{|c|c|c|}
\hline \multirow{2}{*}{ Característica } & \multicolumn{2}{|c|}{ Processo de Fabricação } \\
\hline & Fundição contínua & Fundição semicontínua \\
\hline Tamanho de Grão médio $(\mu \mathrm{m})$ & 8 & 15 \\
\hline Desvio Padrão $(\sigma)$ & 3 & 5 \\
\hline
\end{tabular}


Os tamanhos de grãos apresentados na tabela 11 se diferenciaram em $46 \%$, embora os materiais tivessem sofrido o mesmo grau de redução e foram recozidos no mesmo tempo e temperatura, o recozimento intermediário realizado também da mesma forma apresentou grande influência na obtenção dos tamanhos de grãos dos materiais acabados, devido aos tamanhos de grãos das bobinas intermediárias e fresadas. Conforme já mencionado anteriormente o processo de fundição semicontínua apresentou um tamanho de grão no material intermediário superior em $46,0 \%$ e ao sofrer os $40 \%$ de redução de espessura e ser recozido apresentou também os $46 \%$ de diferença entre os tamanhos de grãos detectados.
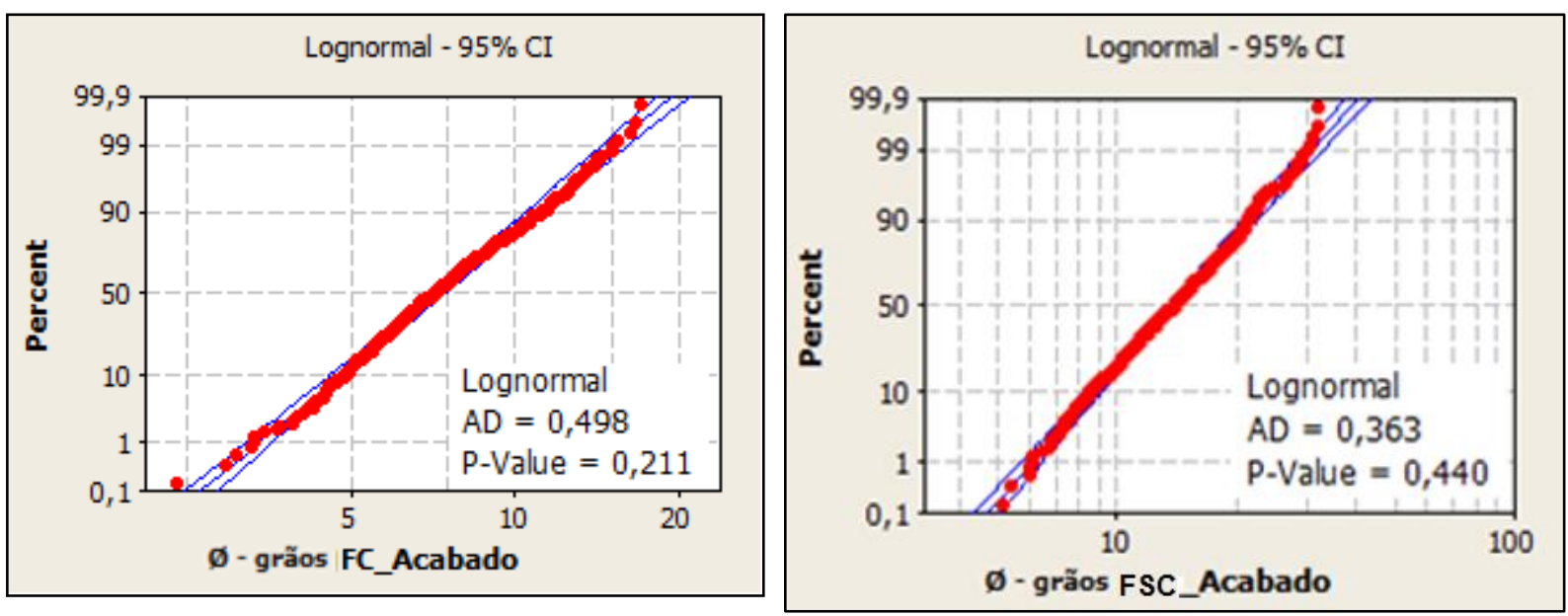

Figura 72 Distribuição dos dados de tamanho de grão para os dois processos (acabado mole).

A avaliação da distribuição dos dados (vide Figura 72) se comportou diferentemente das etapas anteriores para o material proveniente do processo de fundição contínua, ou seja, o material acabado proveniente do processo de fundição contínua que havia apresentado distribuição do tipo Gamma na bobina fresada e no material intermediário, passou a apresentar uma distribuição do tipo Lognormal no material acabado, já o material produzido pelo processo de fundição semicontínua apresentou o mesmo tipo de distribuição dos dados, sendo detectado a distribuição do tipo Lognormal em todas as etapas de produção da bobina, inclusive no material acabado. Verma et al. (2013) descrevem que a deformação altera a distrubuição lognormal para o latão 70:30, devido ao alogamento preferencial da estrutura de grãos ao longo da direção de laminação, durante 15\% e 30\% de deformação, os 
grãos moles alongam enquanto os grãos duros não alteram seus tamanhos significativamente, obtendo-se uma distribuição bimodal, ou seja, nas condições estudadas por Verma et al. (2013) o aumento da redução de espessura provaca a alteração nas distribuições, conclusão valida apenas para o processo de fundição contínua que apresentou distribuição do tipo Gamma nas duas primeiras etapas de processo e no final do processo apresentou distribuição do tipo lognormal para um redução de $40 \%$ final.
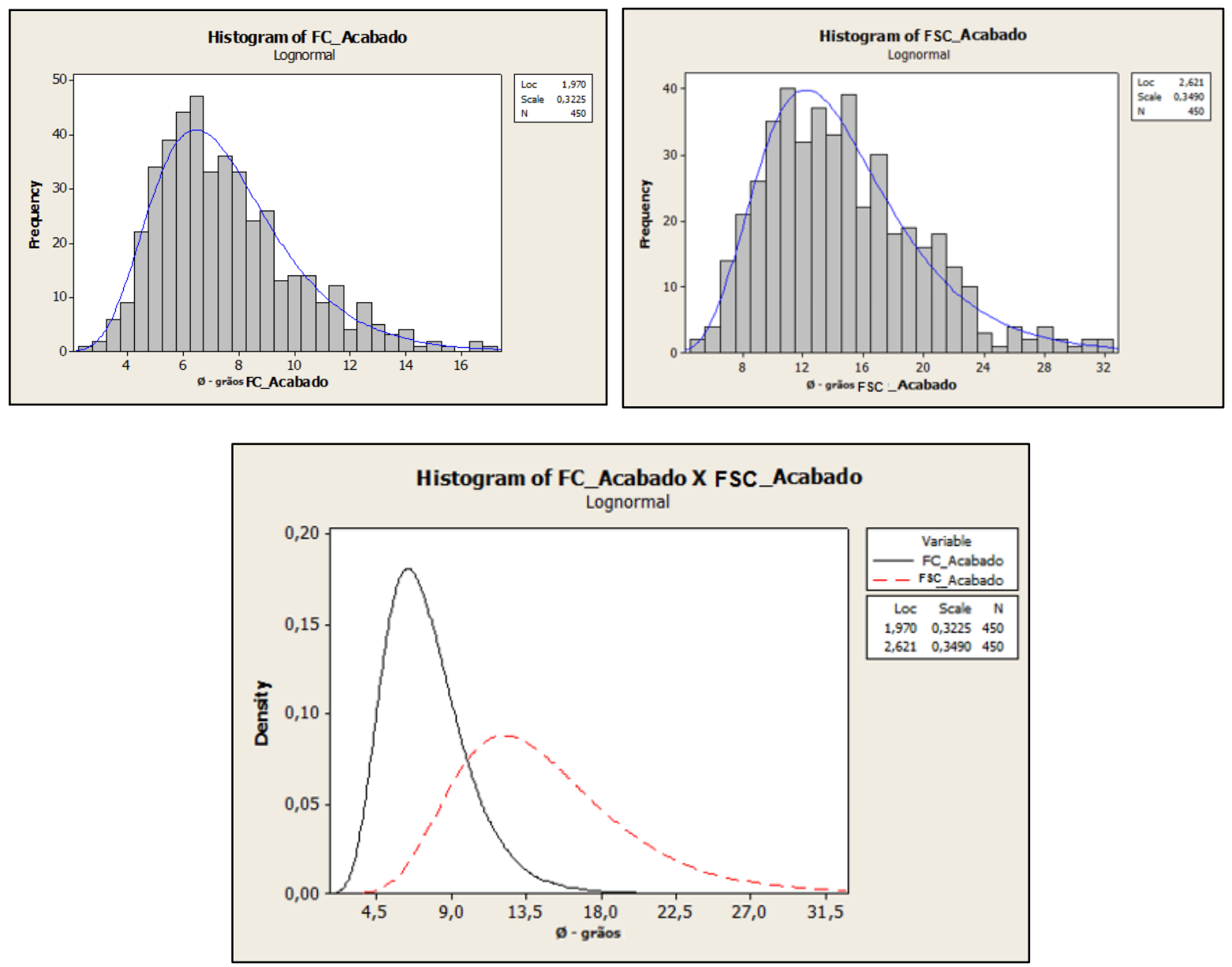

Figura 73 Histograma do tamanho de grão dos processos de fundição contínua e de fundição semicontínua dos materiais acabados.

Os tipos de distribuições são iguais (Lognormal), porém, os resultados médios apresentados e a dispersão dos valores obtidos para os tamanhos de grãos são diferentes. Através dos histogramas da Figura 73, podemos verificar que o processo de fundição contínua apresenta tamanhos de grãos de 2 a $17 \mu \mathrm{m}(88,2 \%)$ com maior frequência próximo a média encontrada $8 \mu \mathrm{m}$, o processo de fundição 
semicontínua apresentou tamanhos de grãos de 5 a $32 \mu \mathrm{m}$ (84,3\%), com maior frequência próximo a média de $15 \mu \mathrm{m}$. Apesar do processo de fundição contínua apresentar um tamanho de grão médio inferior, sua dispersão foi de 3,9 \% (entre os valores mínimos e maximos) superior em relação ao material fabricado inicialmente pelo processo de fundição semicontínua, podendo esta diferença está associada ao histórico de processo, ou seja, devido ao tamanho de grão inicial do fresado.
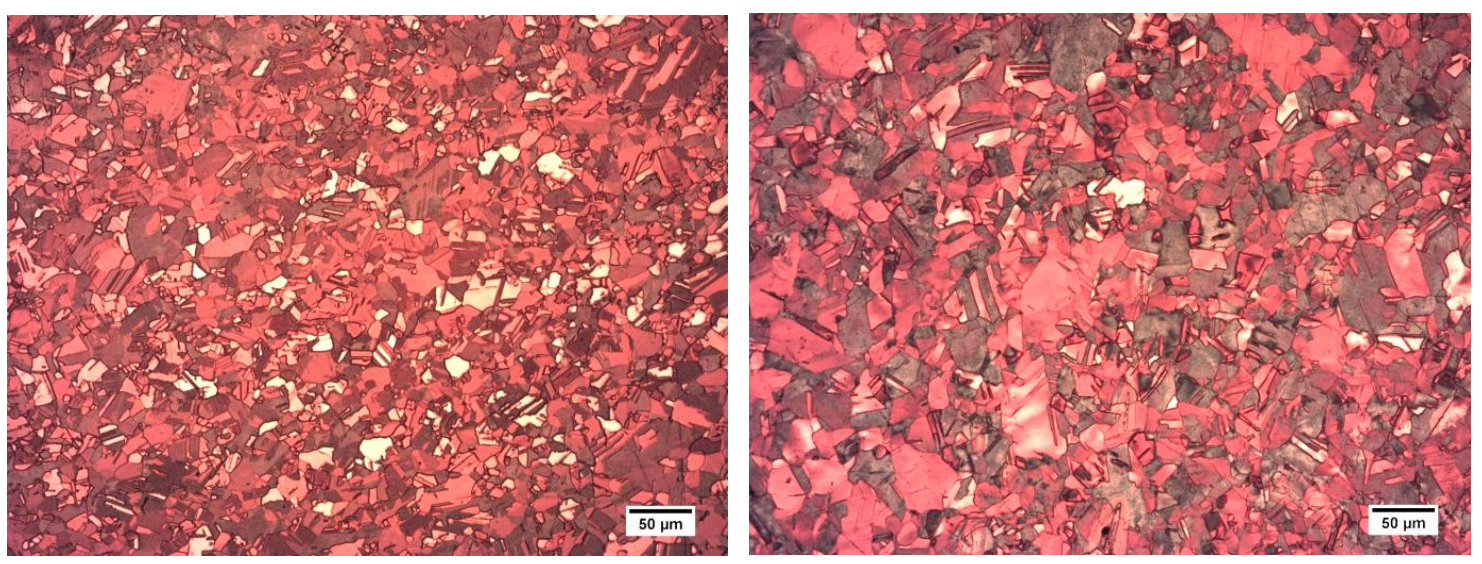

Figura 74 Micrografias (a) Processo de fundição contínua e (b) Processo de fundição semicontínua materiais acabados recozidos (mole).

Através das microestruturas apresentadas na Figura 74 é possivel observar a superioridade do tamanho de grão obtido no material proveniente do processo de fundição semicontínua referenciado acima.

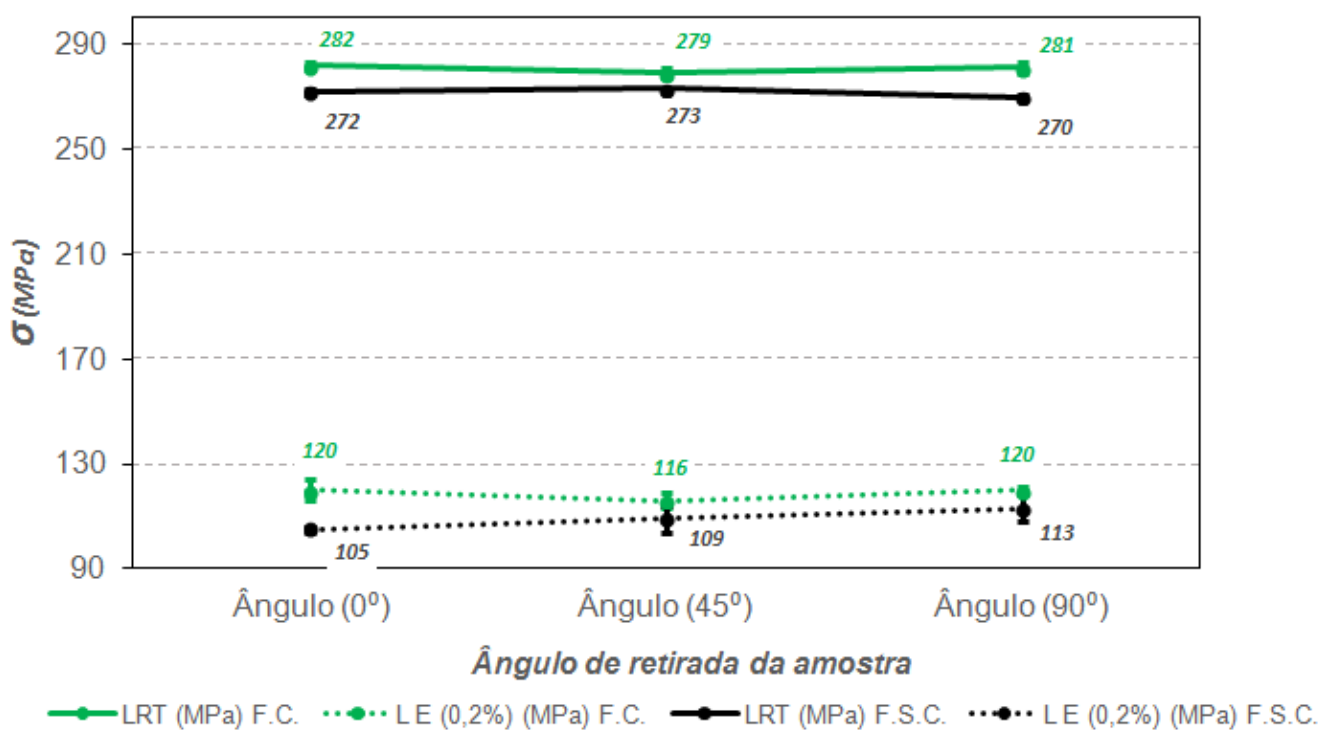

Figura 75 Resultados médios das propriedades físicas do material com espessura $1,10 \mathrm{~mm}$ mole, para os dois processos F.C. e F.S.C.. 


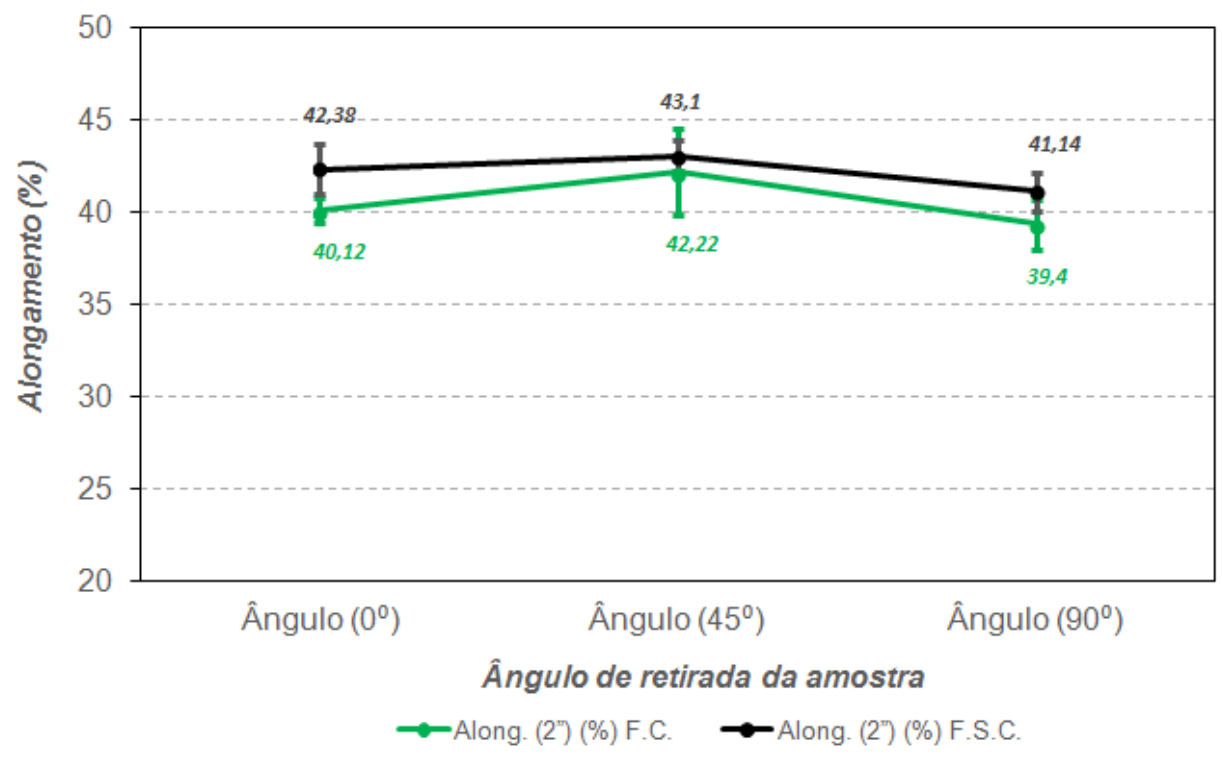

Figura 76 Resultados médios do alongamento do material com espessura $1,10 \mathrm{~mm}$ no estado encruado para os dois processos F.C. e F.S.C..

Os resultados médios das propriedades mecânicas encontrados para os dois processos, demonstrados nas Figuras 75 e 76, não apresentaram diferenças significativas entre eles e nem tão pouco entre os ângulos, diferenciando-se em no máximo $10 \mathrm{MPa}$, com um valor de limite de resistência a tração levemente inferior em 3,5\% para o processo de fundição semicontínua que apresentou um tamanho de grão ligeiramente superior (46\%). Ao contrário do material intermediário os desvios padrões obtidos não ultrapassaram os 4,60 \% com relação aos limites de escoamento obtidos. Esses resultados nos permitem afirmar que o tamanho de grão apresenta diferenças muito mais significativas que o limite de resistência à tração para os materiais moles. Os resultados em formato de tabela podem ser visualizados no APÊNDICE G.

Os ensaios de dureza realizados no material acabado mole com a espessura de $1,10 \mathrm{~mm}$ são demonstrados na tabela 12 , podendo ser verificado uma diferença significativa de 29,5\%, com desvios padrões semelhantes e superiores em duas vezes aos desvios detectados no material encruado, em função é claro do estado em que o material se encontra (mole), cuja variação de dureza é mais pronunciada, corroborando com o que foi descrito na caracterização do material intermediário com espessura de 1,83 $\mathrm{mm}$ mole. 
Tabela 12 Resultados médios de dureza (HR30T) obtidos na espessura de 1,10 mm, material acabado mole.

\begin{tabular}{ccc}
\hline \multirow{2}{*}{ Característica } & \multicolumn{2}{c}{ Processo de Fabricação } \\
\cline { 2 - 3 } & Fundição contínua & Fundição semicontínua \\
\hline Dureza média $(\mu)$ & 28,8 & 20,3 \\
Desvio Padrão $(\sigma)$ & 1,64 & 1,72 \\
\hline
\end{tabular}

Em função dos resultados obtidos de dureza para o material acabado, julgouse necessário a elaboração de uma curva de amolecimento visando verificar se a dureza encontrada é característica de material completamente recristalizado. A Figura 77 demonstra a curva de amolecimento para o material em estudo na espessura do material acabado para os dois processos.

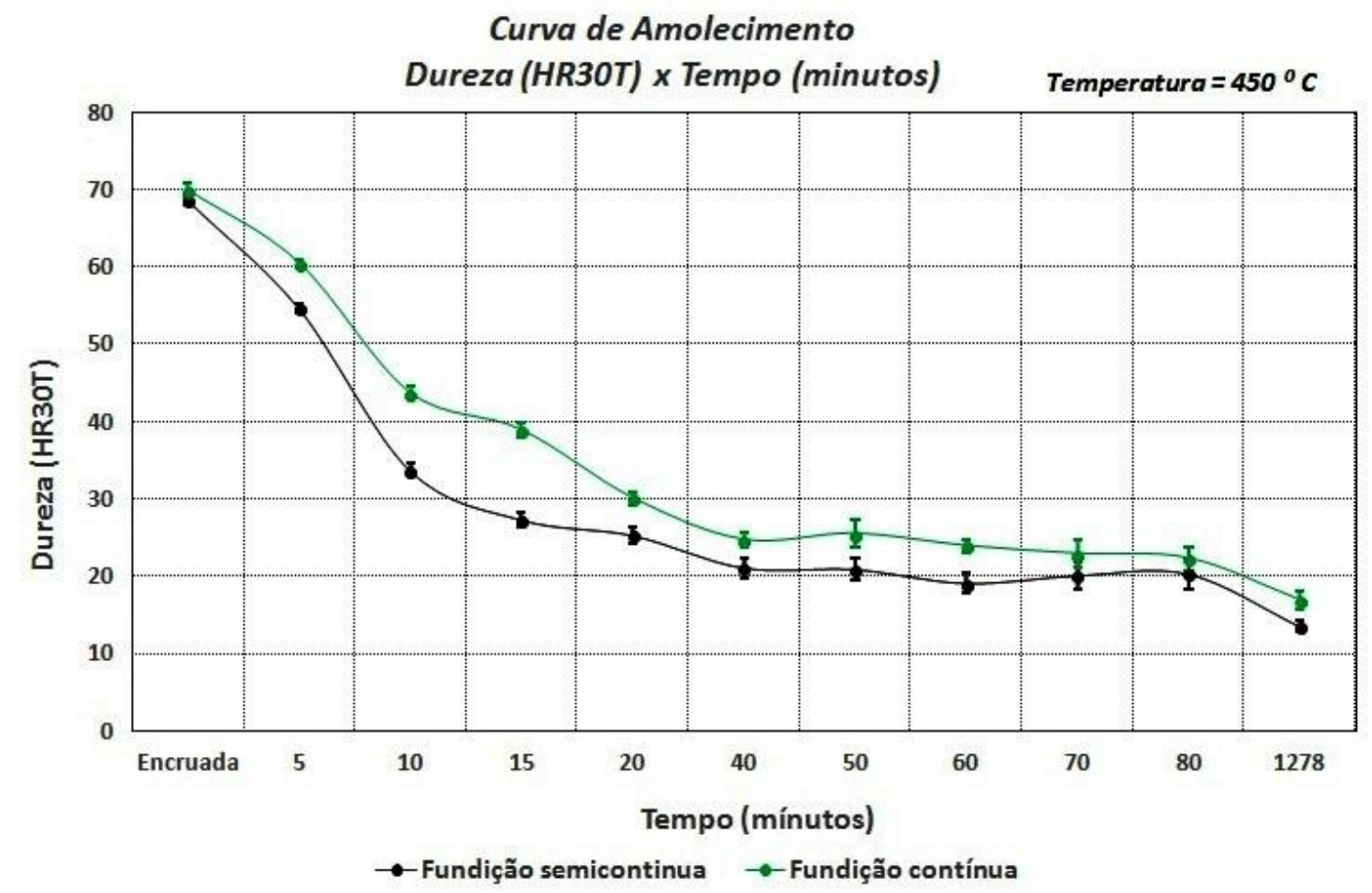

Figura 77 Curva de amolecimento do material acabado com espessura $1,10 \mathrm{~mm}$ para os dois processos F.C. e F.S.C..

A curva de amolecimento do material em estudo nos demonstra uma queda de dureza acentuada após 20 minutos de forno, obtendo-se 57\% de diminuição da dureza do material encruado, ocorrendo uma certeza estabilização próxima aos 40 minutos de forno. Uma análise metalografica da amostra de 20 minutos comprovou a 
recristalização total dos grãos. Os tamanhos de grão obtidos são referentes à faixa de tamanho de grão OS015 da ASTM B 36, tabela 4 da norma, a qual especifica tamanho de grão rescristalizado mínimo e máximo $25 \mu \mathrm{m}$ com o tamanho de grão nominal de $15 \mu \mathrm{m}$.

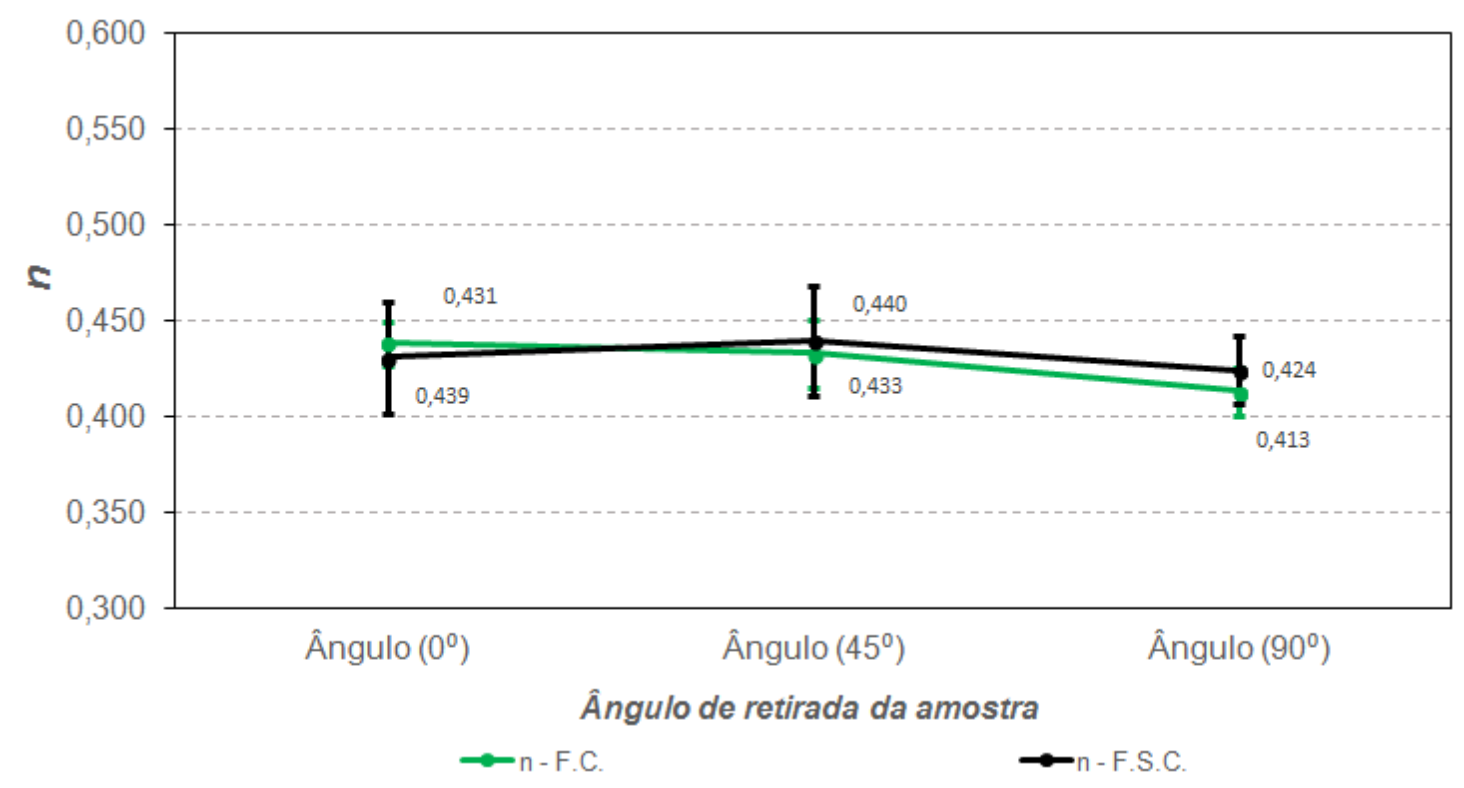

Figura 78 Resultados médios dos coeficientes de encruamento $(n)$ do material com espessura $1,10 \mathrm{~mm}$ acabado no estado recozido para os dois processos F.C. e F.S.C..

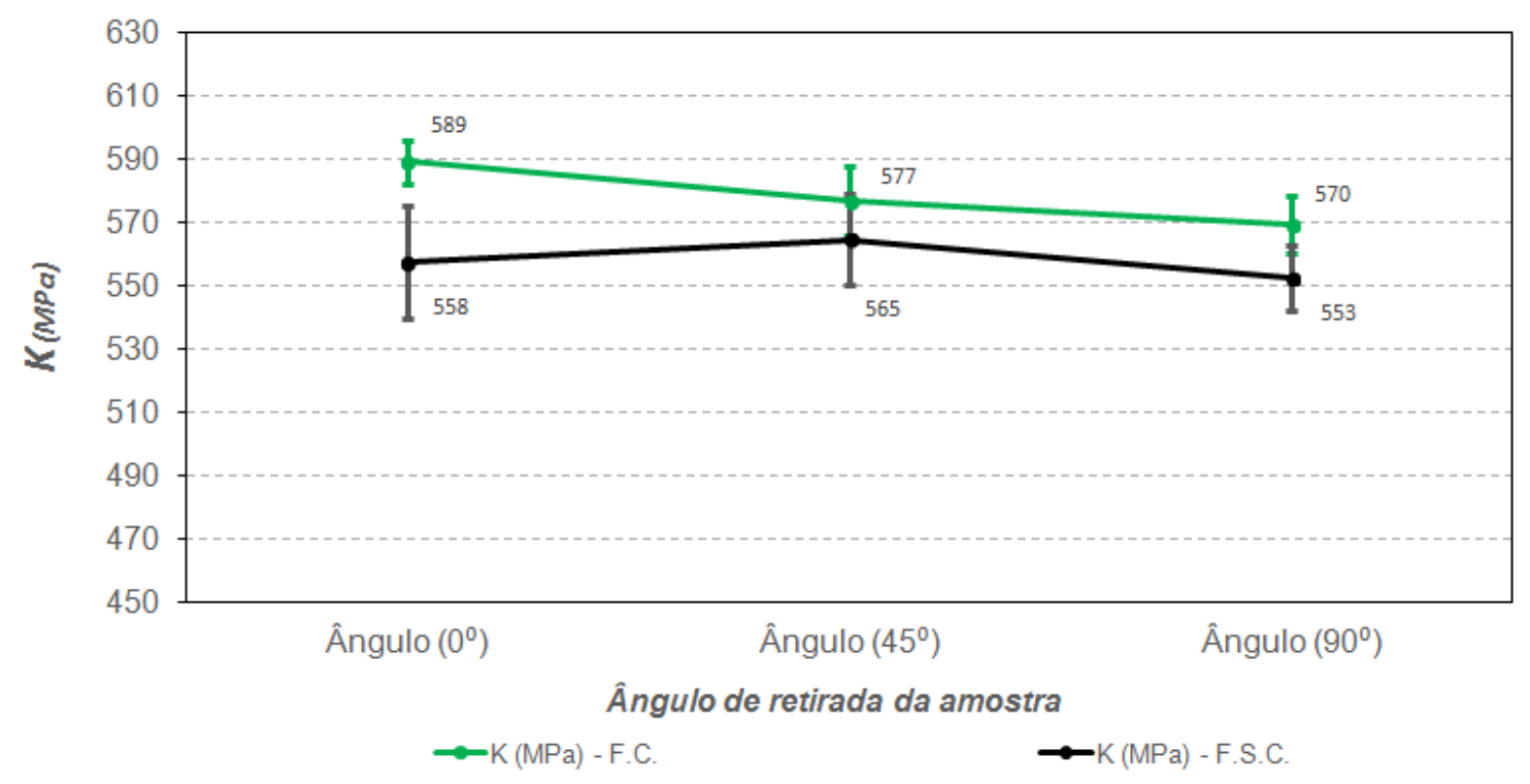

Figura 79 Resultados médios dos coeficientes de resistência $(K)$ do material com espessura $1,10 \mathrm{~mm}$ acabado no estado recozido para os dois processos F.C. e F.S.C.. 
Os valores obtidos para os coeficientes de encruamento (n) (vide Figura 78) são similares e apresentaram desvios padrões considerados baixos, quando comparados com os valores encontrados nos materiais intermediários, não demonstrando diferenças significativas entre os processos, já o coeficiente de resistência (K) (vide Figura 79) apresentou uma diferença em porcentagem baixa de $5,42 \%$, porém, para o processo de fundição semicontínua o desvio padrão obtido é $61,1 \%$ maior que o obtido no processo de fundição contínua, podendo ser decorrente da maior variação de tamanho de grão encontrada, visto que os desvios padrões encontrados nos limites de resistência à tração e limite de escoamento também se apresentaram baixos. Os valores no formato de tabela podem ser visualizados no APÊNDICE $H$.

Tabela 13 Resultados médios dos coeficientes de anisotropia planar $\Delta r$ e anisotropia normal $r$ dos materiais acabados (a) fundição contínua e (b) fundição semicontínua.

\begin{tabular}{|c|c|c|c|c|}
\hline Ângulo & $\mathrm{R}$ & $\mathrm{R} \mu$ & $r_{\text {NORMAL }}$ & $\Delta r$ \\
\hline \multirow{5}{*}{$0^{\circ}$} & 0,875 & \multirow{5}{*}{0,962} & \multirow{15}{*}{0,98} & \multirow{15}{*}{0,04} \\
\hline & 0,972 & & & \\
\hline & 0,950 & & & \\
\hline & 0,962 & & & \\
\hline & 1,052 & & & \\
\hline \multirow{5}{*}{$45^{\circ}$} & 0,922 & & & \\
\hline & 0,934 & & & \\
\hline & 1,006 & 0,954 & & \\
\hline & 1,008 & & & \\
\hline & 0,938 & & & \\
\hline \multirow{5}{*}{$90^{\circ}$} & 1,087 & \multirow{5}{*}{1,030} & & \\
\hline & 1,021 & & & \\
\hline & 0,983 & & & \\
\hline & 1,095 & & & \\
\hline & 1,128 & & & \\
\hline
\end{tabular}

(a)

\begin{tabular}{|c|c|c|c|c|}
\hline Ângulo & $\mathrm{R}$ & $\mathrm{R} \mu$ & $r_{\text {NORMAL }}$ & $\Delta r$ \\
\hline \multirow{5}{*}{$0^{\circ}$} & 0,928 & \multirow{5}{*}{0,965} & \multirow{15}{*}{0,930} & \multirow{15}{*}{0,010} \\
\hline & 0,960 & & & \\
\hline & 1,027 & & & \\
\hline & 0,982 & & & \\
\hline & 0,926 & & & \\
\hline \multirow{5}{*}{$45^{\circ}$} & 0,945 & \multirow{5}{*}{0,926} & & \\
\hline & 0,891 & & & \\
\hline & 0,940 & & & \\
\hline & 0,948 & & & \\
\hline & 0,913 & & & \\
\hline \multirow{5}{*}{$90^{\circ}$} & 0,931 & \multirow{5}{*}{0,910} & & \\
\hline & 0,927 & & & \\
\hline & 0,873 & & & \\
\hline & 0,938 & & & \\
\hline & 0,947 & & & \\
\hline
\end{tabular}

(b)

Previamente foi possivel verificar que não existem diferenças significativas nos limites de resistência à tração dos materiais nos ângulos ensaiados (vide Figura 75), o que nos demonstraria uma possível detecção da formação de "orelha" durante o processo de estampagem dos copos, afirmação essa comprovada no material intermediário através da diferença apresentada e do ensaio de "orelha" realizado 
posteriormente, assim como no caso do material acabado. Portanto, os resultados apresentados na tabela 12 nos permite afirmar que o material acabado não apresentará a formação de "orelha" após o processo de repuxo profundo e/ou estampagem de peças.

Tabela 14 Resultados médios dos ensaios de orelha, material acabado mole.

\begin{tabular}{ccc}
\hline Características & \multicolumn{2}{c}{ Processos de Fabricação } \\
\cline { 2 - 3 } & Fundição continua & Fundição semicontínua \\
\hline \% Orelha & 0,46 & 0,44 \\
(Desvio Padrão) & $(0,06)$ & $(0,08)$ \\
\hline
\end{tabular}

Conforme mencionado no comentário anterior os resultados apresentados confirmaram a não formação de "orelha" para os materiais acabados moles, ou seja, os materiais produzidos nas mesmas condições após as bobinas fresadas não apresentaram o fenômeno de formação de 'orelha', mesmo o processo de fundição semicontínua que apresentou no processo intermediário em decorrência do provável grau de redução de espessura total aplicável ao material e consecutiva formação de textura, pois os materiais foram recozidos nas mesmas condições, sendo alterado apenas o grau de redução inicial aplicado, devido às estruturas do material produzido na fundição contínua versus o material produzido pelo processo de fundição semicontínua mais laminação a quente.

Tabela 15 Resultados médios dos ensaios Erichsen, material acabado mole.

\begin{tabular}{cc}
\hline Processos de Fabricação & Índice Erichsen $(\mathbf{m m})$ \\
\hline Fundição contínua & 11,84 \\
(Desvio Padrão) & $(0,10)$ \\
\hline Fundição semicontínua & 12,06 \\
(Desvio Padrão) & $(0,08)$ \\
\hline
\end{tabular}


Os resultados dos ensaios Erichsen encontrados apresentaram uma diferença pequena de apenas 1,82\%, apesar do tamanho de grão apresentar uma diferença mais significativa de $46 \%$ e o tamanho de grão ser correlacionável com o índice Ericksen para os materiais estudados e processados igualmente os resultados obtidos devem ser considerados igual devido a abaixa diferença detectada.

\subsection{Curva limite de conformação obtida pelo ensaio de tração uniaxial (IRSID) e ensaio Erichsen}

As curvas limite de conformação foram construídas em duas etapas, sendo o lado esquerdo da curva construído através dos ensaios de tração uniaxial, com quatro corpos de prova apresentando diferentes geometrias (entalhes), já expostos na introdução teórica e no item materiais e métodos, e o lado direito da curva através do ensaio Erichsen, cuja deformação é biaxial e, portanto, se obtém as deformações $\varepsilon_{1}$ e $\varepsilon_{2}$ positivas. O objetivo principal do presente estudo foi avaliar a possível diferença entre os processos de fundição contínua versus fundição semicontínua, produzidos após a bobina fresada nas mesmas condições, avaliando as possíveis diferenças apresentadas nas etapas intermediárias e de acabamento dos materiais processados.

Na Figura 80 será apresentada a curva limite de conformação resultante do presente estudo, os dados dispersos na cor preta são referentes ao processo de fundição semicontínua seguida da laminação a quente e os dados dispersos em verde são referentes ao processo de fundição contínua, as linhas de tendência (polinomial de $2^{\circ}$ ordem) são adicionadas nos gráficos visando melhor entendimento da distribuição dos dados na construção das curvas. 
Curva limite de Conformação

(ensaio de tração uniaxial e Erichsen)

UNS C22000

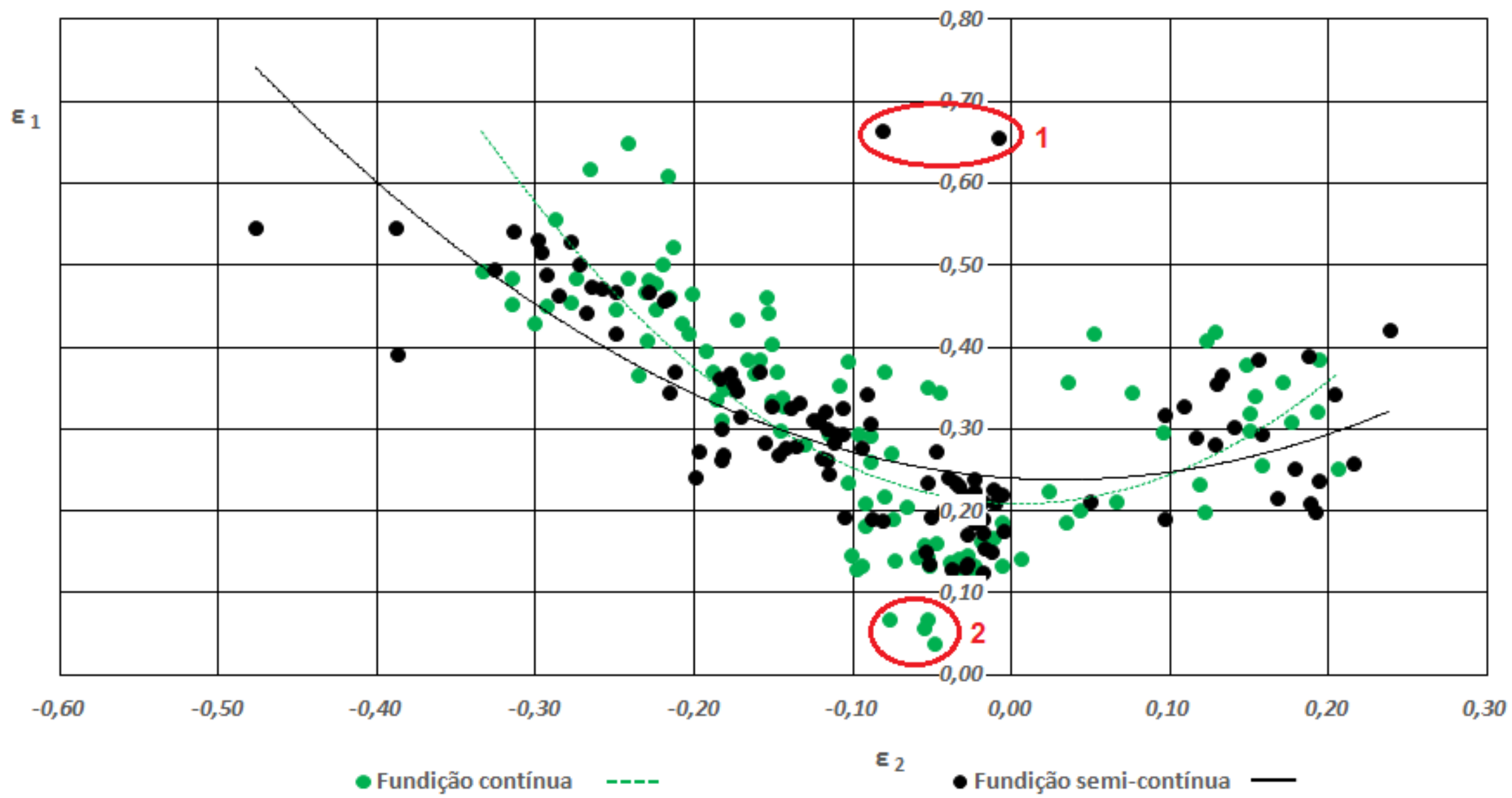

Figura 80 Curva limite de conformação obtida pelo ensaio de tração uniaxial (IRSID) e ensaio Erichsen do material acabado, processo fundição contínua e fundição semicontínua (identificação de pontos dispersos excessivamente 1 e 2). 
Avaliando a Figura número 80 é possível verificar dispersões excessivas, como a dos pontos circulados na parte superior pontuados com o número 1 para 0 processo de fundição semicontínua e nos pontos circulados na parte inferior identificados com o número 2 resultantes do processo de fundição contínua e de maior importância, pois exercem grande influência na obtenção média da deformação plana e/ou da obtenção da CLC $_{0}$, responsável por $80 \%$ das falhas evidenciadas na industria automobilistica conforme referenciado por Xavier, Plaut e Schön (2014).

O processo de fundição semicontínua apresenta superioridade em $31 \%$ na $\mathrm{CLC}_{0}$ quando comparado ao processo de fundição continua, porém, apenas para a deformação plana, pois para deformações menores $\varepsilon_{2}$ superiores a 0,10 e inferiores a - 0,15 o comportamento dos materiais passa a ser diferente, assim como para deformações maiores $\varepsilon_{1}$ superiores a 0,25 e 0,30, o processo de fundição continua demonstra superioridade, desta forma para a fabricação de peças que exijam maiores deformações de estiramento biaxial, tração e embutimento profundo o processo de fundição contínua torna-se mais interessante.

O tamanho de grão médio obtido para o processo de fundição semicontínua de $15 \mu \mathrm{m}$ quando comparado ao tamanho de grão médio obtido no processo de fundição continua $8 \mu \mathrm{m}$, apresentam uma diferença de $46 \%$ e não exercem influência na obtenção das curvas, pelo menos para a deformação planar, pois tamanhos de grãos inferiores deveriam apresentar curvas superiores e não é esse o resultado evidenciado na Figura número 80 , assim como foi descrito na revisão da literatura. Davis (2001) demonstra duas ligas de latão com mesma espessura, com diferenças entre os tamanho de grão de $29 \%$ e diferença no teor de zinco de $5 \%$, apresentando curvas limites de conformação praticamente identicas, com uma diferença na deformação plana obtida de apenas $10 \%$.

Objetivando avaliar e identificar os pontos dispersos, contruiu-se uma curva limite de conformação identica a da Figura 80, porém, separou-se os conjuntos de corpos de prova (formato do marcador gráfico), processos iniciais de fabricação e a coloração diferenciada entre os corpos de prova, tornando-se assim mais fácil a detecção e verificação dos pontos que apresentaram-se dispersos. 


\section{Curva limite de Conformação}

UNS C22000

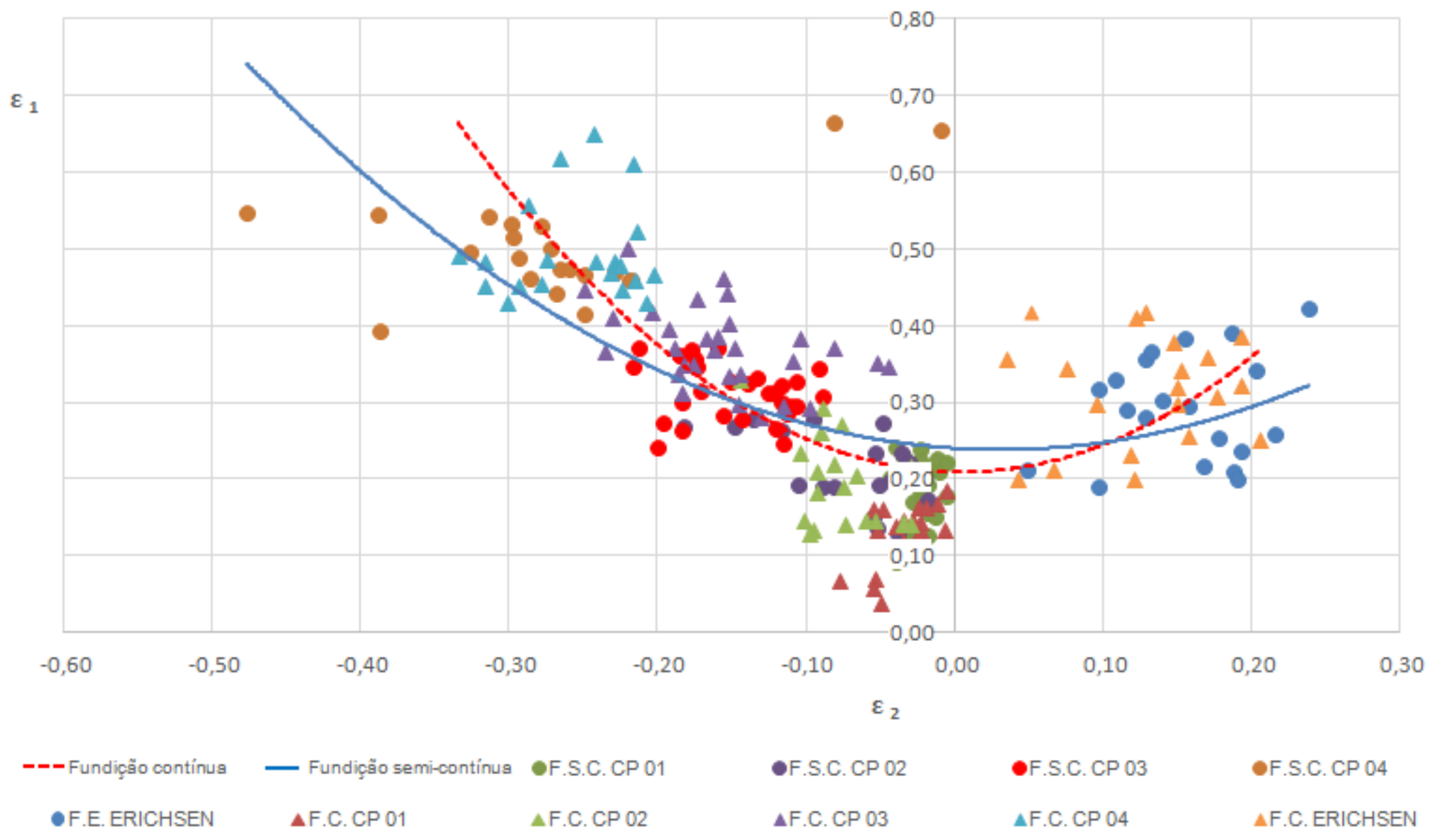

Figura 81 Curva limite de conformação obtida pelo ensaio de tração uniaxial (IRSID) e ensaio Erichsen do material acabado, separação de processos e corpos de prova (fundição contínua e fundição semicontínua). 
Diante do exposto no texto acima e da visualização gráfica da Figura 81 foi possível verificar que os dois pontos dispersos, identificados com o número 1 , foram obtidos no corpo de prova número quatro do processo de fundição semicontínua, já os quatro pontos identificados com o número 2, foram detectados no corpo de prova número um do processo de fundição contínua. Os quatro pontos identificados com o número dois, exercem maior influencia na determinação da curva, para o processo de fundição contínua, pois são cruciais para a obtenção média da mínima deformação alcançada pelos processos, portanto, uma re-avaliação destes pontos se torna muito importante e interessante.

Os pontos dispersos identificados com o número 1 são referentes aos círculos 3 e 4 demonstrados na Figura 81, podendo ser verificado uma maior deformação no sentido uniaxial e consecutivamente de laminação a $0^{\circ}$ dos círculos 3 e 4 , as retas pontilhadas na coloração avermelhada também nos auxiliam nesta confirmação.

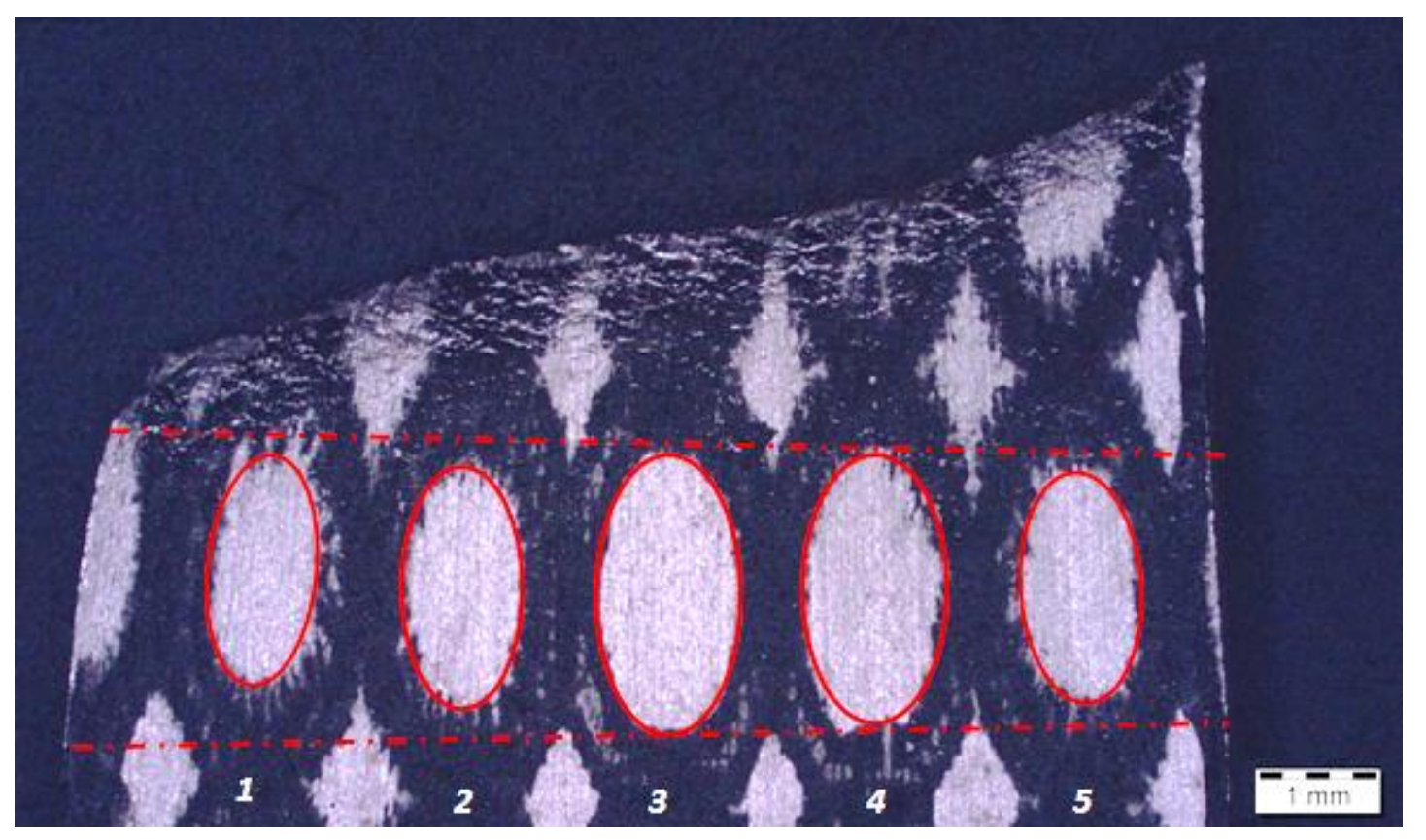

Figura 82 Corpo de prova número 4 do processo de fundição semicontínua, $1^{\circ}$ conjunto de corpos de prova analisados.

Xu et al (2014), utilizaram a metodologia DIC para a elaboração das curvas limite de conformação atráves de ensaios de tração unixial para cobre puro, evidenciando grandes deformações localizadas em determinados pontos e também deformação não homogeneas em pontos localizados, como as dos círculos evidenciados na Figura 82, porém, essa análise foi realizada em cobre puro com 
espessura fina $(0,10,0,20$ e $0,40 \mathrm{~mm})$ e tamanho de grão variando de 17,4 a 166,3 $\mu \mathrm{m}$ que exerce grande influência na deformação, principalmente localizada.

A Figura 83 demonstra o corpo de prova número 1 do processo de fundição contínua referente aos pontos identificados com o número 2 na Figura 80 , ao efetuar as medições das larguras (sentido oposto a laminação) e os comprimentos (sentido de laminação) efetuou-se a medição dos círculos na parte superior ao rompimento identificada com o retângulo branco, ao invés de efetuar a medição nos círculos identificados nos retângulos na cor vermelha, desta forma a defomação encontrada apresentou valores inferiores, quando comparadas aos outros corpos de prova.

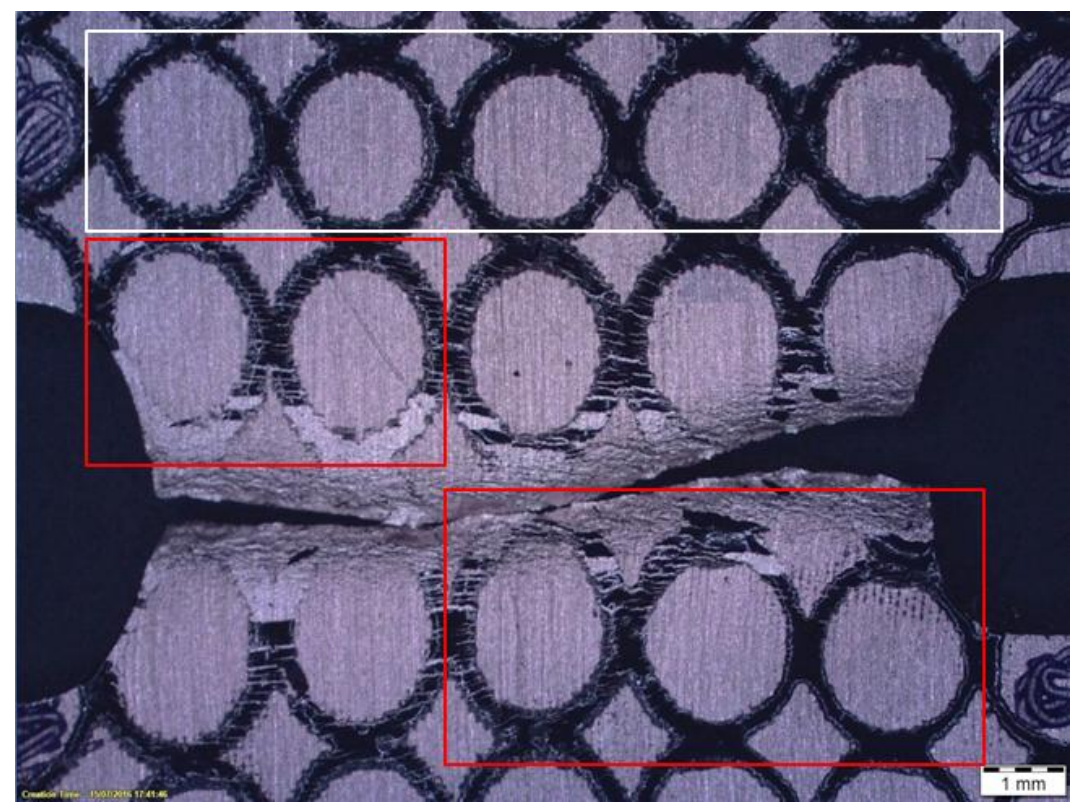

Figura 83 Corpo de prova número 1 do processo de fundição contínua, $4^{\circ}$ conjunto de corpos de prova analisados.

Diante da re-avaliação descrita acima efetuou-se novamente a medição dos círculos identificados com o número 1 e 2 . Os valores antes do rompimento dos corpos de prova foram mantidos, para o corpo de prova 4 do processo F.S.C. efetuou-se três medições na largura e três medições no comprimento para cada círculo utilizando a média para o cálculo das deformações $\varepsilon_{1}$ e $\varepsilon_{2}$, o corpo de prova número um do processo de fundição contínua foi realizado a medição dos círculos identificados com o retângulo vermelho, demonstrando na Figura 83 e novamente plotou-se as curvas limite de conformação, com os novos dados. 


\section{Curva limite de Conformação}

UNS C22000

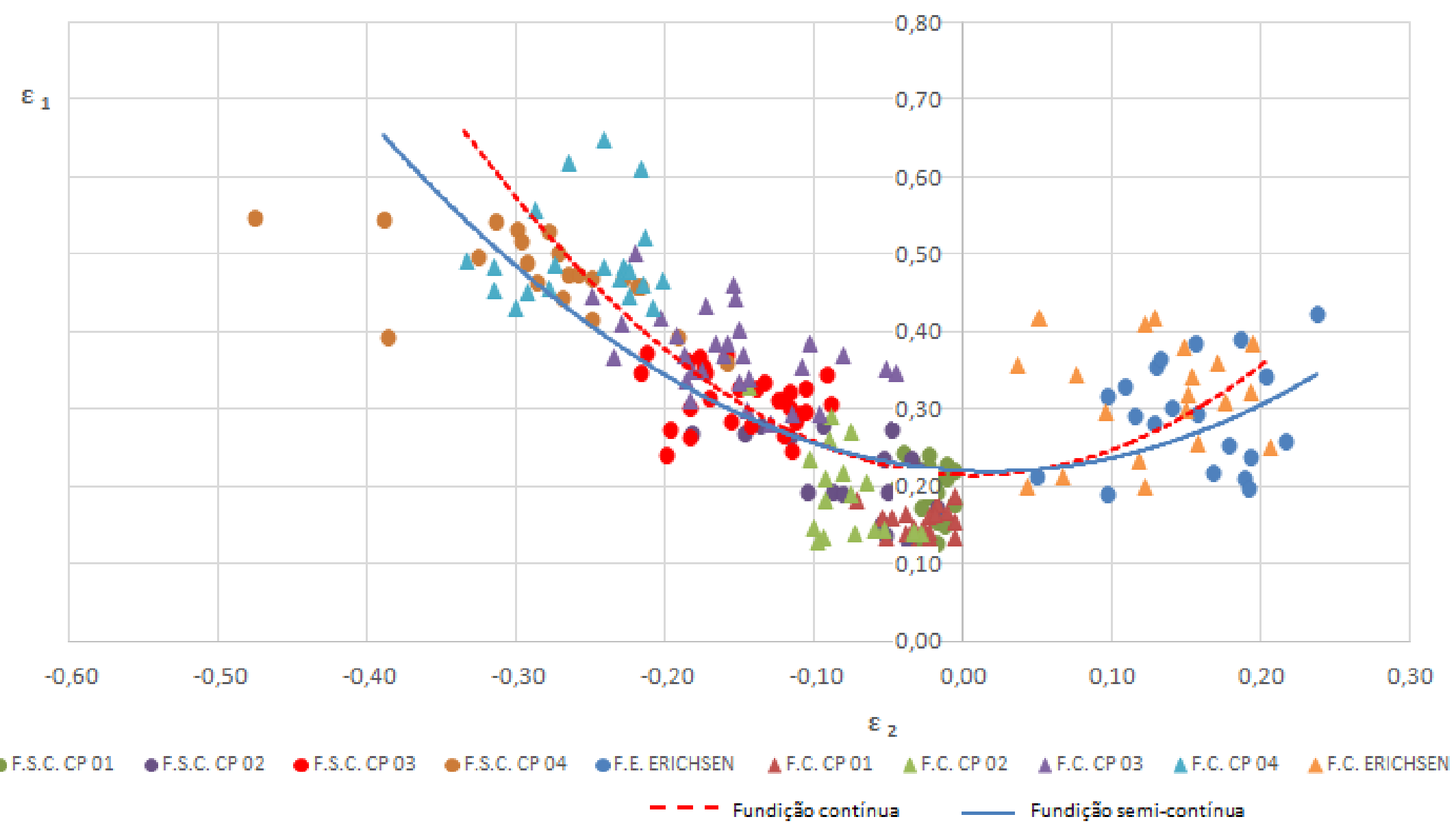

Figura 84 Curva limite de conformação material acabado, após reavaliação dos pontos dispersos. 
Após as reavaliações construiu-se novamente as curvas limites de conformação para os dois processos demonstrados na Figura 84, podendo constatar pelas linhas de tendência que o processo de fundição semicontínua apresenta uma curva levemente superior, apenas na região do eixo $\varepsilon_{1}$ (deformação plana) e para as deformações no eixo $\varepsilon_{2}$ inferiores $a \pm 0,10$. A superioridade do processo de fundição semicontínua passou de $31 \%$ para $19 \%$, ou seja, os quatro corpos de prova reduziram a deformação plana do processo de fundição semicontínua em 12\%. Para as outras deformações, estiramento biaxial, tração uniaxial e embutimento profundo o processo de fundição contínua apresenta-se superior.

Plaut (2003) afirma que no estado plano de deformação $\left(\varepsilon_{2}=0\right.$ ou $\left.\mathrm{CLC}_{0}\right) \circ$ valor obtido na maior deformação $\varepsilon_{1}$ é igual ao valor do coeficiente de encruamento e/ou expoente de encruamento $(n)$, porém, em ambos os processos o valor obtido para a condição $\varepsilon_{2}=0$ da maior deformação $\varepsilon_{1}$ foi de 0,1865 para $\circ$ processo de fundição semicontínua, contra 0,1504 para o processo de fundição contínua e os valores de $\mathrm{n}$ obtidos através da equação de Hollomon para os processos foram de 0,4313 para fundição semicontínua e 0,4389 para a fundição contínua, porém, Plaut (2003) não especifica em quais condições os valores devem ser iguais, não tão pouco para quais materiais essa afirmação é válida.

Hosford e Duncan (1999) descrevem que o valor é aproximadamente igual não afirmando igualdade, Keeler (1994) afirma que a diminuição do $\mathrm{n}$ reduz a deformação no estado plano assim como demonstrado por Melander (1982) na própria curva limite de conformação para cobre o material Tough Pitch Copper (liga C11000). 


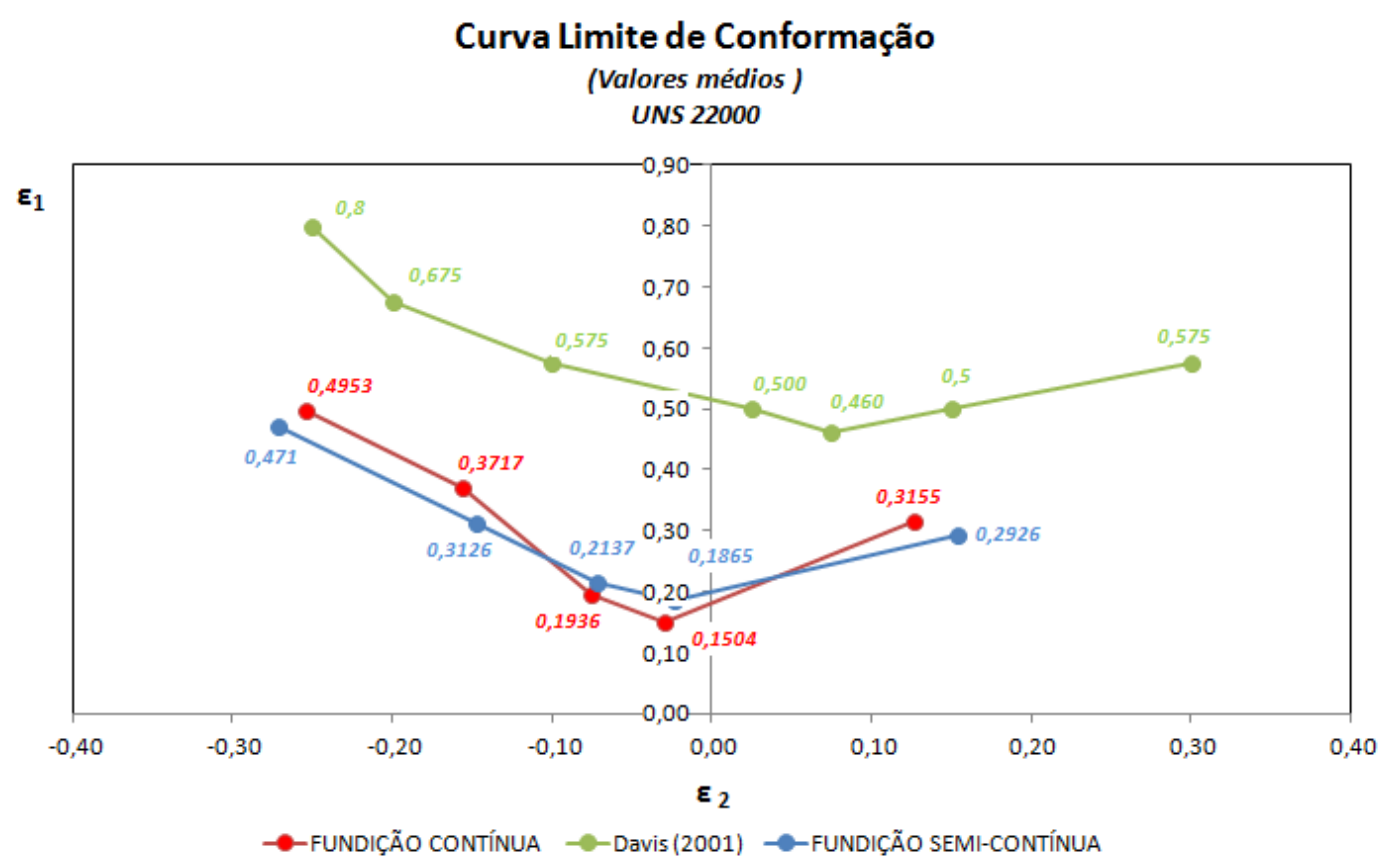

Figura 85 Curva limite de conformação média e a exposta por Davis (2001).

A Figura 85 demonstra à curva limite de conformação média dos valores obtidos no presente estudo, facilitando desta forma a visualização das conclusões expostas nos parágrafos acima, maior deformação no estado plano para o processo de fundição semicontínua, existindo um cruzamento entre os processos para deformações $\varepsilon_{2}$ inferiores a $-0,10$ e superiores a 0,05. A curva teórica exposta por Davis (2001) tem espessura de 0,69 mm e tamanho de grão $17 \mu \mathrm{m}$, características bem diferentes do material em estudo, visto que a espessura, tamanho de grão, tamanho dos círculos utilizados nos ensaios, coeficiente de atrito, forma de obtenção das curvas exerce grande influência na obtenção das CLC's. Os ensaios realizados através de corpos de prova de tração uniaxial determinam o lado esquerdo da curva limite de conformação, porém, as geometrias dos corpos são extremamente importantes para se obter as curvas corretamente, Holmberg, Enquist e Thilderkvist (2003) determinaram a curva limite através de comparações com simulações no software Abaqus/Standard visando obter a geometria correta dos corpos de prova e a realização dos ensaios físicos. Plaut (2003) descreve que para ensaios no plano como no caso do ensaio de tração uniaxial, não existe a influência do punção de sua curvatura e consecutivamente do atrito, desta forma a curva limite de conformação se posiciona mais baixa quando comparada a obtida através de ensaios de Nakazima e/ou Marciniaki. 
5.7 Curva limite de conformação obtida pelo ensaio de Nakazima reduzido

Conforme descrito na revisão da literatura às curvas limites de conformação podem ser obtidas de diversas formas, e cada forma apresenta certa particularidade, ensaios de tração uniaxiais (metodologia IRSID) não possuem a influência do atrito durante a deformação, com isso se obtém uma deformação inferior. Alterações no formato do punção modificam o posicionamento do lado direito da CLC, desta forma julgou-se necessário elaborar a curva limite de conformação através da utilização do punção hemisférico reduzido, visando efetuar a comparação com os resultados obtidos pela CLC determinada através da metodologia proposto pelo IRSID.

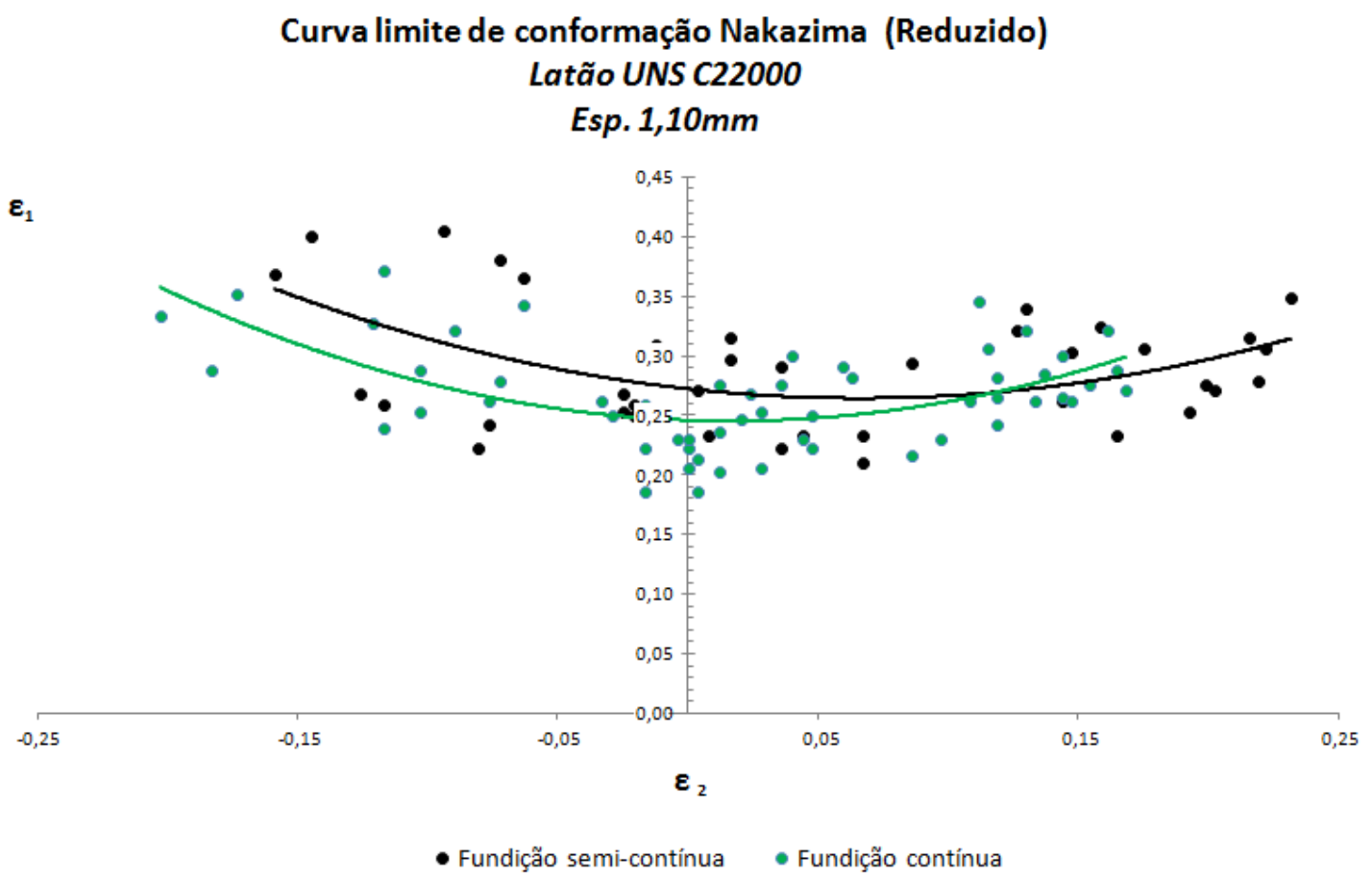

Figura 86 Curva limite de conformação Nakazima reduzido.

A Figura 86 demonstra a curva limite de conformação obtida para o ensaio de punção hemisférico, Nakazima reduzido em $60 \%$, o processo de fabricação, fundição semicontínua, apresentou uma curva média levemente superior em $11 \%$ no caminho de deformação planar e as deformações médias detectadas superiores as obtidas pela metodologia proposta pelo IRSID, estando essa afirmação relacionada com a forma de obtenção da curva, pois ensaios realizados no plano (tração uniaxial) não possui influência do punção e nem de sua curvatura e desta forma se 
obtém uma CLC mais baixa quando as obtidas pelos ensaios de Nakazima ou Marciniak (PLAUT, 2003). A diferença obtida entre os processos de fabricação e as metodologias utilizadas é de $37 \%$ para o processo de fundição contínua e para o processo de fundição semicontínua é de $31 \%$.

Stachowicz (1989) demonstrou em sua publicação a CLC para diferentes tamanhos de grão da liga UNS C23000 que se difere da liga em estudo, apenas em $5 \%$ do teor de zinco contido em sua composição e conforme evidenciado na revisão da literatura essa diferença pode ser considerada insignificante para esses materiais. Para as amostras com tamanho de grão 41,8 $\mu \mathrm{m}$ detectou-se uma $\mathrm{CLC}_{0}$ de 0,30 , para o material em estudo com tamanho de grão de $15 \mu \mathrm{m}$ obteve-se uma $\mathrm{CLC}_{0}$ de 0,27 , lembrando que existe a diferença de obtenção do tamanho de grão, ou seja, os tamanhos de grão não foram quantificados da mesma forma e o ensaio realizado pelo Stachowicz não foi reduzido como utilizado no presente estudo, porém, é possível verificar certa coerência entre os dados obtidos, diferentemente dos expostos por Davis (2001).

\subsection{Curva limite de conformação raiz $\left(\mathrm{CLC}_{0}\right)$}

A curva limite de conformação raiz $\left(C C_{0}\right)$ é pertinente ao ponto onde a deformação $\varepsilon_{1}$ é a maior e a deformação $\varepsilon_{2}$ é o valor mais próximo de zero, segundo Ayres, Brazier e Sajewski (1979) a deformação $\varepsilon_{2}$ é $\pm 2 \%$ para deformação planar. Para obtenção dos pontos, optou-se pela elaboração de três tipos de corpos de prova diferentes, sendo o primeiro conforme o IRSID, o segundo conforme Björklund e Nilsson (2014) e por fim o proposto por Wagoner (1980 e 1981), porém, com dimensões reduzidas em seis vezes, pois os corpos de prova propostos por Wagoner possuem cotas muito grandes como a largura e comprimento e desta forma seria necessária a adaptação de uma garra para a realização dos ensaios de tração uniaxial dos materiais. 


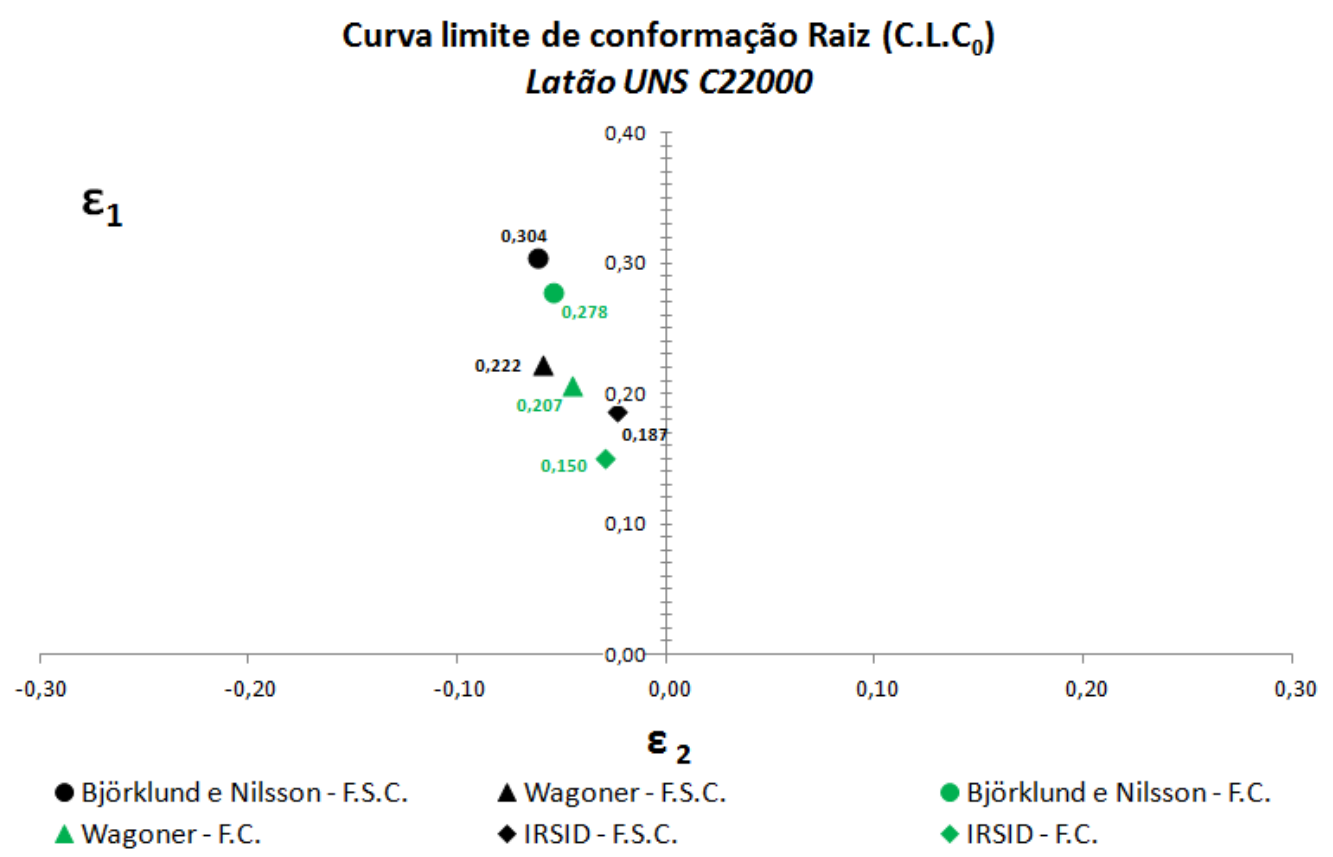

Figura 87 Curva limite de conformação raiz (CLC $)$.

O processo de fundição semicontínua, apresentou valores superiores em todos os tipos de corpos de prova estudados, sendo detectada uma diferença de $19,78 \%$ na deformação $\varepsilon_{2}$ para o corpo de prova proposto pelo IRSID entre os processos. Para o corpo de prova proposto por Wagoner com dimensões reduzidas a diferença encontrada entre os processos de fabricação foi de $6,75 \%$, na deformação $\varepsilon_{2}$, já o corpo de prova proposto por Björklund e Nilsson apresentou uma diferença de 8,55\% na deformação $\varepsilon_{2}$. A diferença de deformação apresentada entre os corpos de prova está diretamente relacionada com os raios de confecção dos entalhes dos corpos de prova, pois corpos de prova com raios mais acentuados concentram uma quantidade de tensão superior e diminuem a deformação que o material alcança. A largura e comprimento dos entalhes também influenciam principalmente na deformação $\varepsilon_{1}$, desta forma um balanceamento destas variações, devem ser levadas em consideração para se obter a melhor deformação planar do material.

O corpo de prova que mais caracteriza a curva limite de conformação raiz é o tipo proposto pelo IRSID, devido a baixo deformação $\varepsilon_{1}$ encontrada e o rompimento centralizado durante os ensaios. 


\subsection{Textura}

A elaboração das figuras de pólo nas amostras $20 \times 10 \mathrm{~mm}$ demonstradas na Figura 88 nos permitiu verificar que os materiais não apresentaram similaridade suficiente para as análises de textura, pois os dados analisados nestas condições estatisticamente são inconsistentes, e desta forma torna-se inviável a avaliação do tipo de textura e sua quantificação.

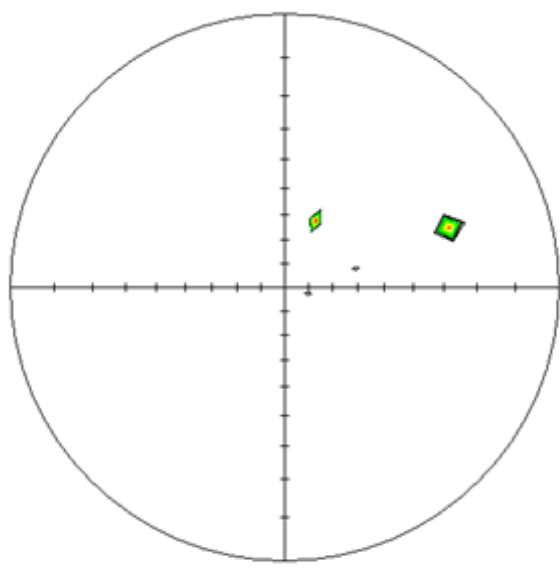

(a)

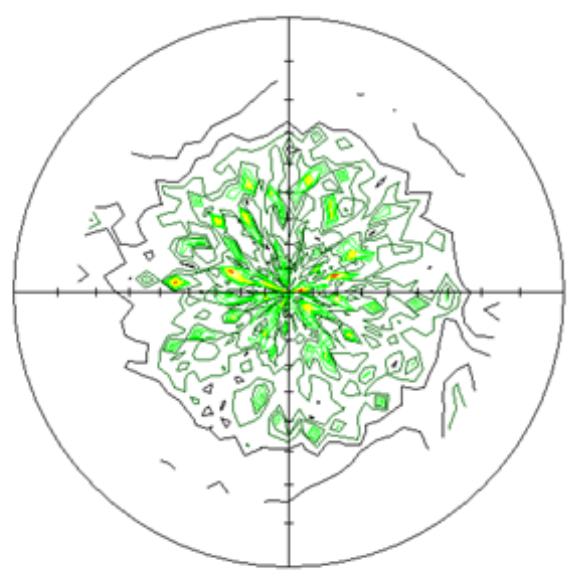

(b)

Figura 88 Figura de polo (a) Material fresado processo de fundição contínua (220) e (b) Material fresado processo de fundição semicontínua (220).

Em função da não similaridade apresentada pelas figuras de pólo, aumentouse a geometria das amostras de $20 \times 10 \mathrm{~mm}$ para $25 \times 20 \mathrm{~mm}$ e novamente elaboraram-se as figuras de pólo nesta nova condição, porém, apenas para o material na espessura de $1,10 \mathrm{~mm}$ no estado recozido e encruado.

Ao contrário da Figura 88 a Figura 89 apresenta a simetria necessária para se analisar a textura e se obter estatisticamente dados confiáveis para a avaliação da textura contida no material, sendo assim analisou-se a textura do material acabado conforme a seguir. 


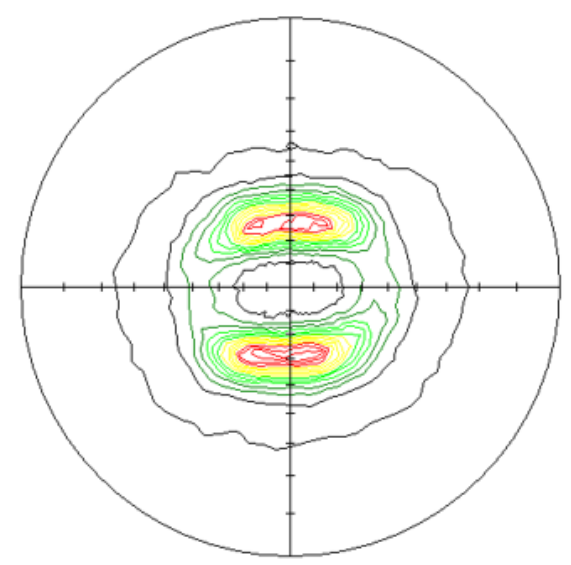

(a)

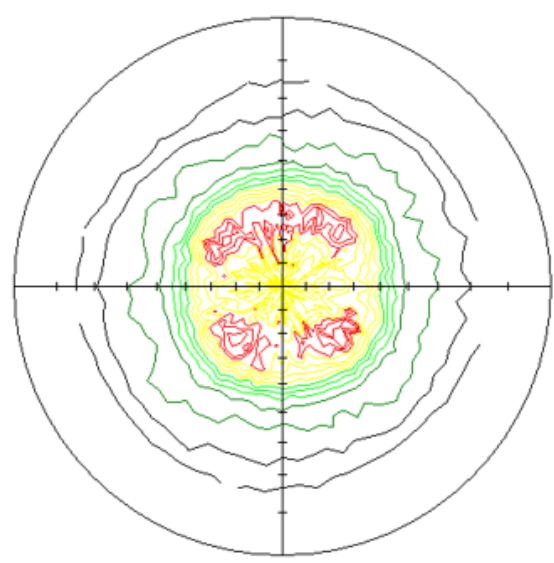

(b)

Figura 89 Figura de pólo (a) Material acabado espessura 1,10 mm encruado do processo de fundição contínua (111) e (b) Material acabado espessura 1,10 mole do processo de fundição contínua (111).

A textura que controla a estampabilidade de uma determinada chapa é decorrente da textura de recristalização, no entanto, essa textura é gerada a partir da textura proveniente do material laminado a frio. A Figura 90 (a) e (b) demonstram as funções de distribuição de orientação (FDO) das chapas laminadas a frio provenientes do processo de fundição contínua e fundição semicontínua. Nos dois casos é possível identificar duas contribuições importantes: uma forte contribuição (acima de 9 vezes da aleatoriedade) em torno de $\varphi 1=45^{\circ}, \Phi=35, \varphi 2=0^{\circ}$, (também visível próximo a $\varphi 1=50^{\circ}, \Phi=90^{\circ}$ e $\varphi 2=45^{\circ}$ ), que corresponde à orientação conhecida como "Latão", e outra próxima a $\varphi 1=90^{\circ}, \Phi=27^{\circ}, \varphi 2=45^{\circ}$, que corresponde à orientação conhecida como "Cobre" ou "Dillamore" (Wierzbanowski, Wronski e Leffers, 2014). Esta última contribuição mostra a principal diferença entre as duas chapas, o material decorrente do processo de fundiçao semicontínua possui uma forte contribuição "Cobre" (acima de 9 vezes da aleatoriedade), enquanto o material produzido pelo processo de fundição contínua possui uma contribuição mais fraca (cerca de 6 vezes da aleatoriedade). 

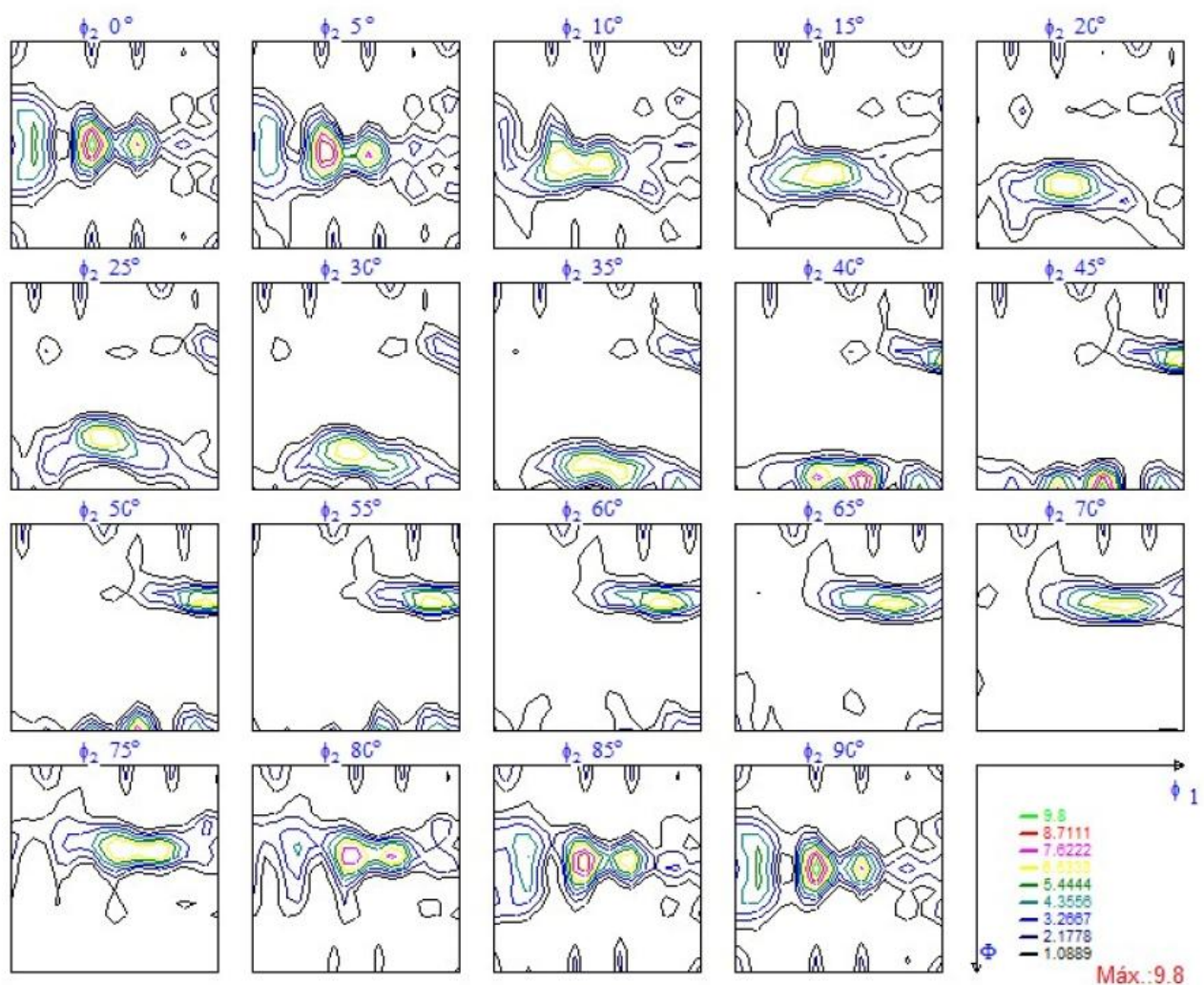

(a)
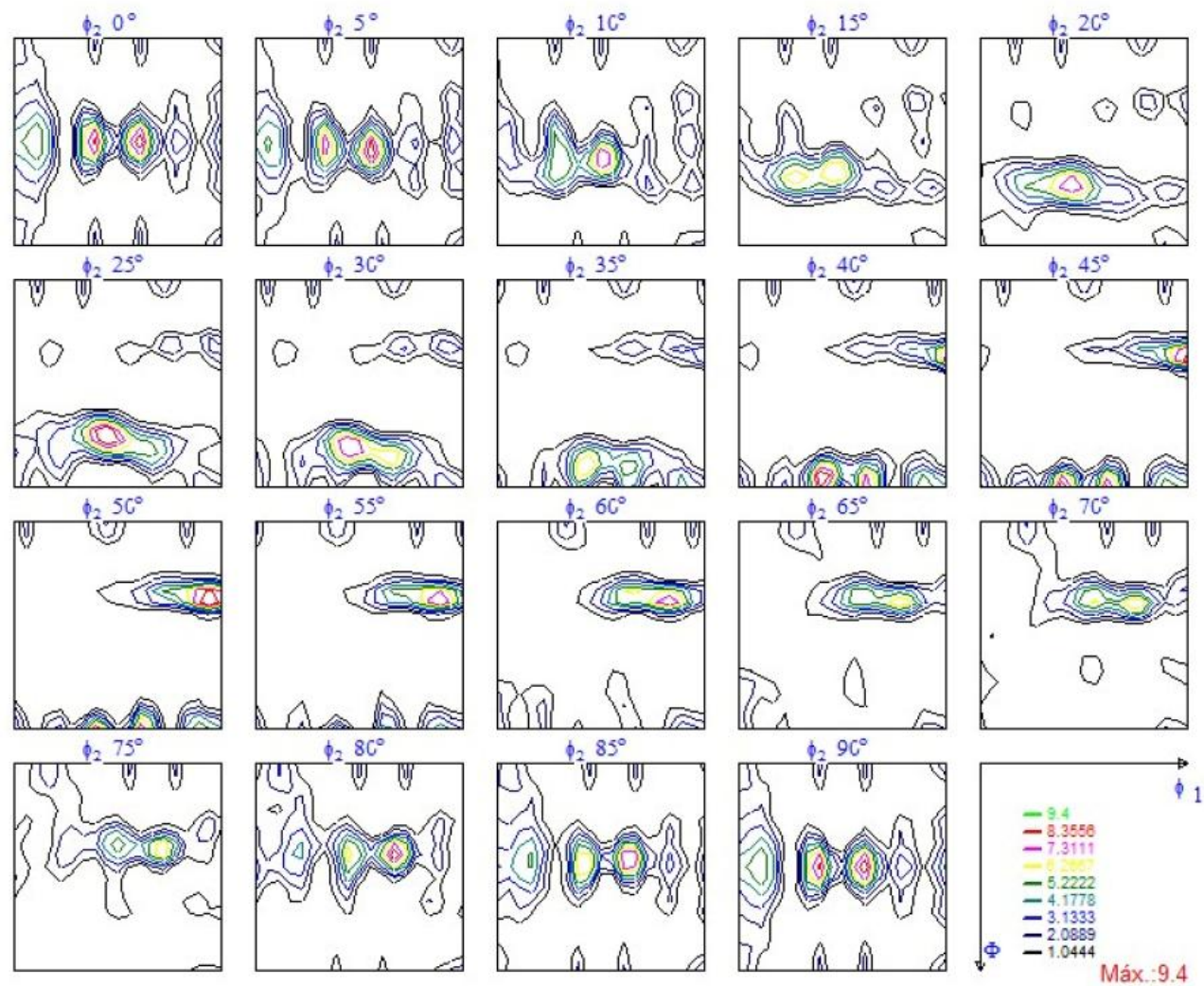

(b)

Figura 90 Função de distribuição de orientação (FDO) do material acabado com espessura 1,10 $\mathrm{mm}$ laminado a frio (encruado) (a) processo de fundição contínua e (b) processo de fundição semicontínua. 
A Figura 91 demonstra as FDO's do material acabado na espessura de $1,10 \mathrm{~mm}$ recozido. A contribuição principal encontrada nestes casos é em $\varphi 1=0^{\circ}$, $\Phi=\sim 30-40^{\circ}, \varphi 2=0^{\circ}$, o que corresponde a orientações entre (102)[010] e (203)[010], também conhecido como "Cube RD" (XIAO et al., 2017). As texturas de recristalização em metais CFC são provenientes dos componentes da textura de laminação a frio. Xiao et al. (2017) demonstra que o componente "Brass" gera um componente próximo a $\varphi 1=80^{\circ}, \Phi=31^{\circ}, \varphi 2=35^{\circ}$, sendo denominado pelos autores de "Brass-R".

Lee e Han (2014) identificaram a origem dos componentes do cubo e da rotação do cubo para a textura de laminação do tipo "Cobre". No caso das chapas analisadas, a diferença principal é a extensão da textura do tipo "Cube RD" ao longo de $\varphi 1$, formando uma fibra.
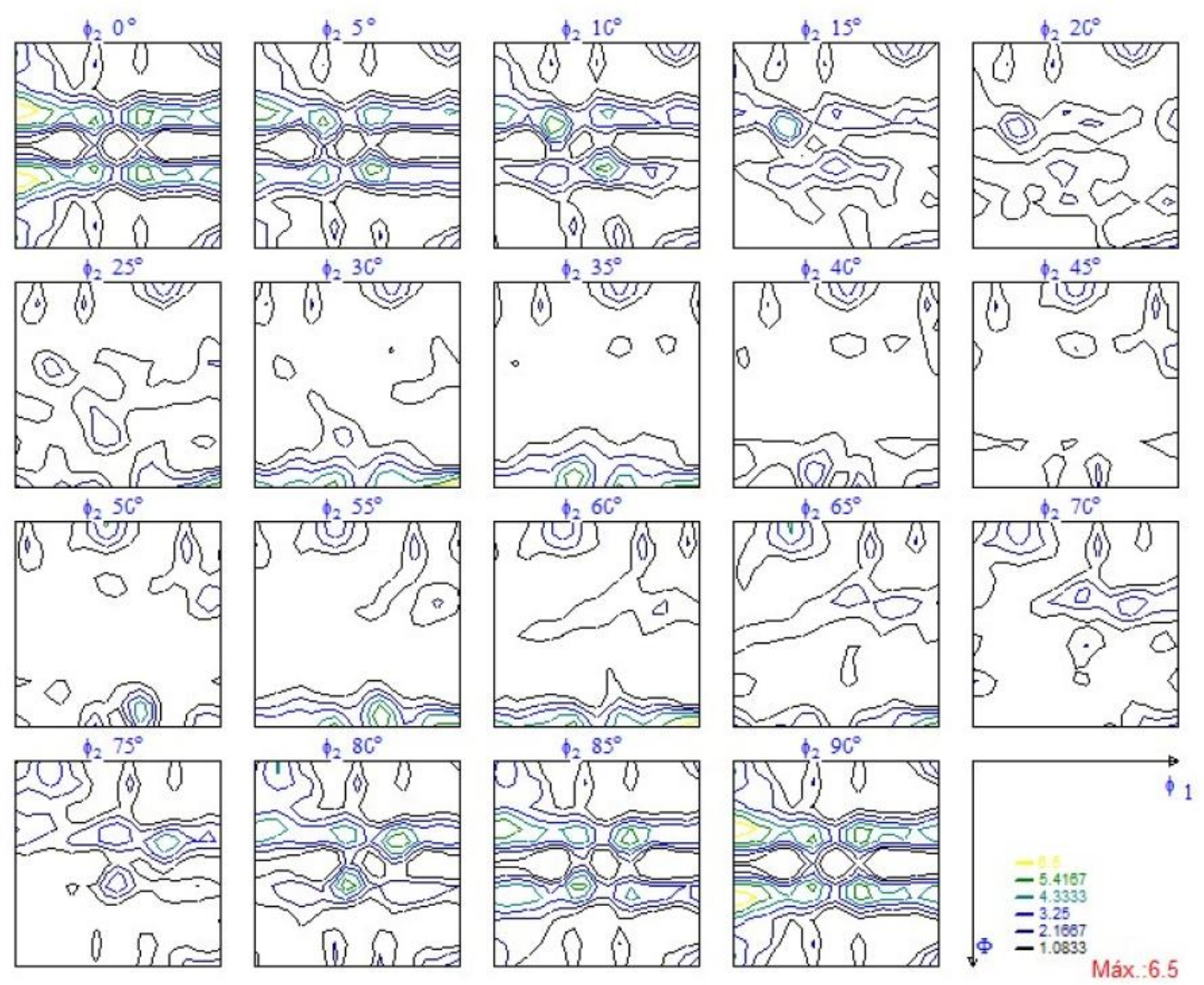

(a) 

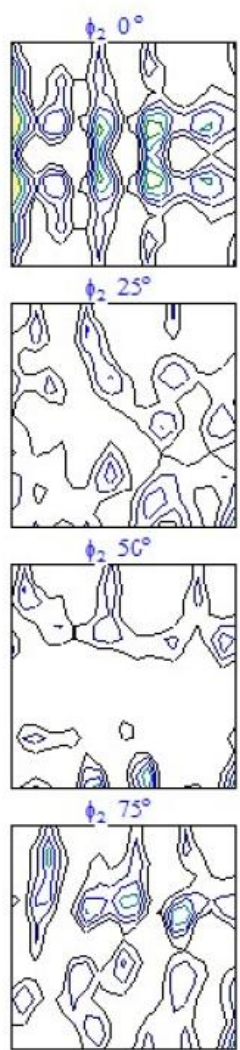
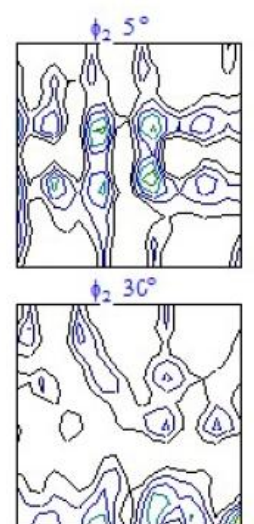

$\phi_{2} 55^{\circ}$

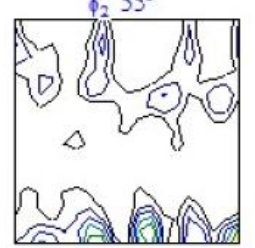

$\phi_{2} 8 \mathrm{C}^{\circ}$

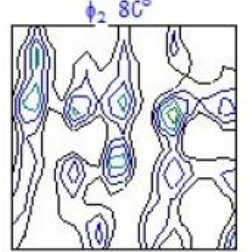

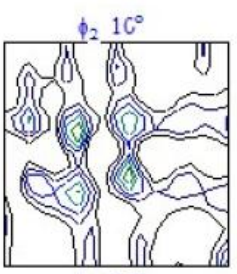

$\phi_{2} 35^{\circ}$

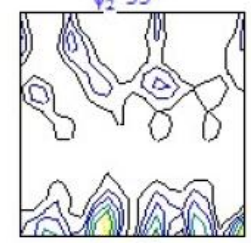

$\phi_{2} 60^{\circ}$

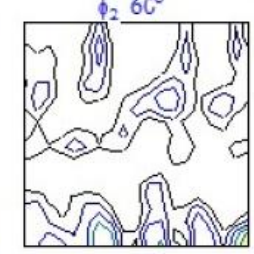

$\phi_{2} 85^{\circ}$

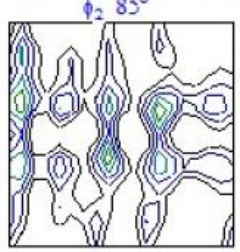

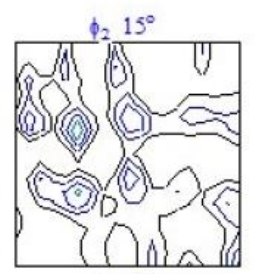

$\phi_{2}, 40^{\circ}$
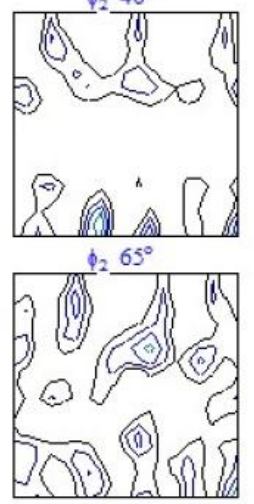

$9 \mathrm{C}^{\circ}$

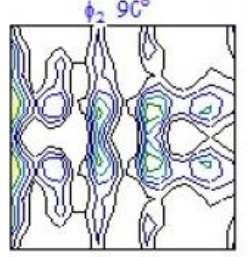

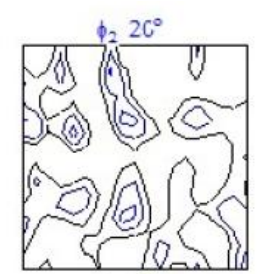

$\phi_{2} 45^{\circ}$

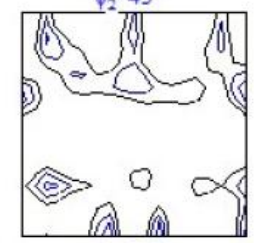

$\phi_{2} 7 \mathrm{C}^{\circ}$
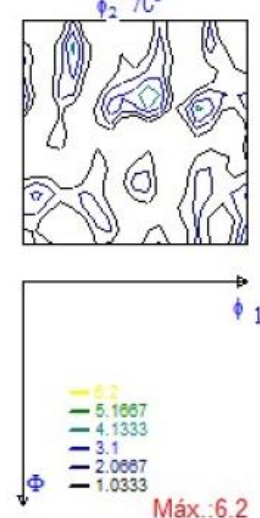

(b)

Figura 91 Função de distribuição de orientação (FDO) do material acabado com espessura 1,10 $\mathrm{mm}$ recozido (a) processo de fundição contínua e (b) processo de fundição semicontínua.

As intensidades ao longo da fibra $\Phi=35^{\circ}\left(\varphi 2=0^{\circ}\right)$ são mostradas na Figura 92. É possível identificar algumas orientações preferencias ao longo desta fibra. O material produzido pelo processo de fundição contínua apresenta intensidades mais uniformes, enquanto o material produzido pelo processo de fundição semicontínua demonstra contribuições discretas ao longo do eixo p1 (e algumas orientações estão ausentes).

Os metais CFC se deformam em $\frac{a_{0}}{2}\{111\}\langle 1 \overline{1} 0\rangle$ רo sistema de deslizamento. $\mathrm{O}$ plano $(\overline{2} 03)$ é interceptado por quatro planos da família $\left\{\begin{array}{lll}1 & 1 & 1\end{array}\right\}$. Dois destes planos apresentam um ângulo de intersecção próximo a $37^{\circ}$, enquanto os outros dois cruzam o plano (203) a cerca de $80^{\circ}$. Obviamente, apenas o primeiro plano está bem orientado, devido a máxima tensão de cisalhamento contida no plano da chapa. Cada um desses planos de deslizamento contém pelo menos uma direção <110> bem orientada para o deslizamento de discordâncias ocorrer nas orientações preferencias contidas na fibra de recristalização, sendo assim podemos concluir que 
a fibra de recristalização presente nas chapas acabadas é ideal para melhorar a estampabilidade das chapas, da mesma forma que uma fibra $\gamma$ é benéfica para a estampabilidade de uma chapa de aço.

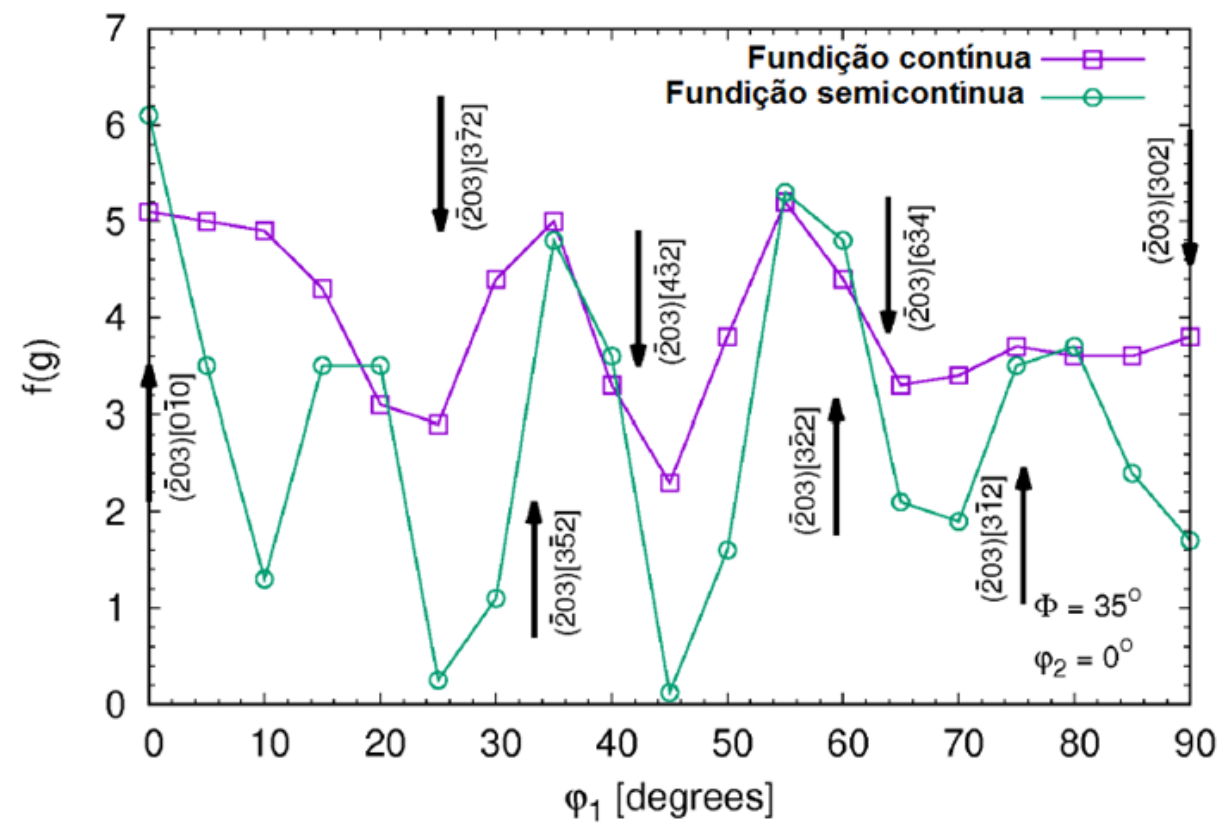

Figura 92 Fibra de recristalização das chapas na espessura acabada.

A diferença entre os dois processos de fabricação seria a natureza discreta da fibra de recristalização, que permite concentrar os grãos em orientações com altos fatores de Schmid, aumentando a estampabilidade. Naturalmente, os grãos em um policristal interagem e a análise atual é muito simplista, no entanto, é suficiente para justificar a estampabilidade equivalente entre as chapas estudadas e/ou processos avaliados. 


\section{CONCLUSÕES}

As conclusões aqui expostas são pertinentes não somente ao objetivo almejado, mais sim com relação às etapas de produção das chapas objeto deste estudo, portanto, será possível o entendimento das variáveis de processo e suas importâncias na fabricação dos resultados finais.

Os materiais intermediários apresentaram graus de encruamento avaliados através do limite de resistência à tração diferente em torno de $10 \%$, devido ao tamanho de grão inicial das bobinas.

A temperatura utilizada no recozimento dos materiais intermediários deverá ser diferente entre os processos, pois o tamanho de grão inicial das bobinas se diferencia em torno de $97 \%$ e influenciam na dispersão dos tamanhos de grãos obtidos no material intermediário.

O material encruado na espessura intermediária proveniente do processo de fundição semicontínua apresentou alongamentos nos três ângulos superiores em 6,5 a $19 \%$ quando comparados com o material produzido inicialmente pelo processo de fundição contínua, tudo isso em função do tamanho de grão inicial e sua homogeneidade.

O material obtido pelo processo de fundição contínua com tamanho de grão inicial de $600 \mu \mathrm{m}$, laminado a frio impondo um grau de redução de espessura de $85 \%$, não apresentou o fenômeno de "orelha" após o processo de recozimento, no qual obteve-se um tamanho de grão de $15 \mu \mathrm{m}$.

A diferença de propriedades mecânicas no plano da chapa $0^{\circ}, 45^{\circ}$ e $90^{\circ} \mathrm{em}$ torno de 9,0 a 9,4 \% confirmou a presença de "orelha" no material intermediário do processo de fundição semicontínua, após o ensaio de "orelha" e os valores de $\Delta \mathrm{r}$ e r NORMAL detectados.

Os tamanhos de grãos não demonstraram correlação e/ou influência com os coeficientes de encruamento obtidos através da equação de Hollomon para as espessuras intermediárias e de acabamento do material em análise UNS C22000. Espessura intermediaria do processo F.S.C. $\mathrm{n}=0,523$, tamanho de grão de $28 \mu \mathrm{m}$ e processo F.C. $n=0,517$, tamanho de grão de $15 \mu \mathrm{m}$. Espessura acabada do 
processo F.S.C. $\mathrm{n}=0,431$ e tamanho de grão de $15 \mu \mathrm{m}$ e processo F.C. $\mathrm{n}=0,439$ e tamanho de grão de $8 \mu \mathrm{m}$.

O material resultante do processo de fundição semicontínua apresentou índices Erichsen superiores em todas as etapas de produção das chapas, pois o tamanho de grão item correlacionável ao índice também apresentou valores superiores.

A formação de "orelha" no material intermediário não exerceu influencia na formação de "orelha" do material acabado, para o grau de redução de espessura aplicado e para o tempo e temperatura utilizados no tratamento térmico final.

A diferença do tamanho de grão do material acabado entre os processos foi de $46 \%$ e do resultado de limite de resistência à tração de apenas 3,60 \%, ou seja, para o material em análise o tamanho de grão influenciou muito pouco nos limites de resistência a tração obtidos.

O coeficiente de resistência K obtido pela equação de Hollomon apresentou uma variação de $13 \%$ no material intermediário e de apenas $5 \%$ no material acabado, demonstrando nenhuma relação com o tamanho de grão obtido nas fases do processo.

A curva limite de conformação obtida para o processo de fundição semicontínua apresentou uma deformação no plano $\varepsilon_{1}$ superior em $19 \%$ para a deformação $\varepsilon_{2}<0,03$, com relação ao material produzido pelo processo de fundição contínua.

O comportamento da curva limite de conformação obtida para os processos de F.C e F.S.C. mostram-se bem diferentes quando comparadas com a curva teórica exposta por Davis (2001), pois a forma de obtenção da CLC exposta na referência foi obtida de forma diferente, porém, não especificada.

Embora a liga pesquisada por Stachowicz (1989) (latão 85/15), apresente uma diferença com relação à liga estudada no presente estudo, devido a composição química e tamanho de grão, os valores de $\varepsilon_{1}$ detectados para a condição de deformação planar $\left(\varepsilon_{2}=0\right)$, podem ser considerados semelhantes 0,30 contra 0,27 , ou com pouca variação, mesmo com o grande número de variáveis para obtenção da CLC. 
Para deformações $\varepsilon_{2}$ superiores a 0,15 (ou 15\%) os comportamentos das curvas são alterados, ou seja, o processo de fundição contínua passa a suportar valores superiores de deformação ao ser imposta a chapa, tanto no campo de tensão uniaxial como no campo de tensão biaxial. Ao avaliar a Figura número 80 nota-se uma dispersão levemente superior dos dados obtidos para o processo de fundição semicontínua e o tamanho de grão obtido nas chapas acabada são diferentes em 46 \% conforme já mencionado.

A diferença detectada na deformação planar $\left(\varepsilon_{2}=0\right)$ entre as metodologias de obtenção da curva aqui estudadas (IRSID X Nakazima reduzido em 60\%) é de 37\% para o processo de fundição contínua e para o processo de fundição semicontínua é de $31 \%$, obtendo-se desta forma uma variação entre as metodologias muito menor quando comparada com a diferença de 70\% mencionada por Schwindt et al. (2015) para o aço DP-780.

O corpo de prova que mais caracteriza a curva limite de conformação raiz $\left(\mathrm{CLC}_{0}\right)$ é o tipo proposto pelo IRSID, devido a baixo deformação $\varepsilon_{1}$ encontrada e 0 rompimento centralizado durante os ensaios.

Três tipos de texturas foram detectadas no material encruado na espessura acabada, sendo a textura tipo "Latão", "Cobre" e "Dillamore". O material proveniente do processo de fundição semicontínua possui uma forte contribuição da textura tipo "Cobre" (acima de 9 vezes da aleatoriedade), enquanto o material produzido pelo processo de fundição contínua possui uma contribuição mais fraca (cerca de 6 vezes da aleatoriedade).

O material acabado na espessura de $1,10 \mathrm{~mm}$ recozido apresentou orientações entre (102)[010] e (203)[010], também conhecido como "Cube RD".

Através da análise de fibra foi possível identificar a diferença entre os processos de fabricação para o material acabado mole, pois o processo de fundição contínua apresenta intensidades mais uniformes, enquanto o material produzido pelo processo de fundição semicontínua demonstra contribuiçoes discretas ao longo do eixo $\varphi 1$ (e algumas orientações estão ausentes).

As fibras de recristalização são ideais para melhorar a estampabilidade das chapas, pois os planos de deslizamento contém pelo menos uma direção <110> bem orientado para o deslizamento das discordâncias ocorrer nas orientações 
preferencias contidas na fibra de recristalização durante o processo de conformação das chapas.

A produção do processo de fundição semicontínua é aproximadamente 10 vezes superior a produção do processo de fundição contínua, mesmo sendo necessário posteriormente efetuar o aquecimento das placas e executar a laminação a quente no processo de fundição semicontinua. Desta forma pode-se concluir que além do processo de fundição semicontínua apresentar as caracteristicas analisadas levemente superior, sua produtividade é 10 vezes maior e nos processos seguintes de laminação a frio é possivel eliminar etapas de recozimento em função da homogeneidade de tamanho de grão obtidos no processo de laminação a quente. 


\section{REFERÊNCIAS}

ASTM INTERNATIONAL. B 130-08: Standard Specification for commercial bronze strip for bullet jackets. West Conshohocken, 2008, 6p.

ASTM INTERNATIONAL. B 131-07: Standard Specification for copper alloy bullet jacket cups. West Conshohocken, 2007, 4p.

ASTM INTERNATIONAL. B 36-13: Standard Specification for brass plate, sheet, strip, and rolled bar. West Conshohocken, 2013, 9p.

ASTM INTERNATIONAL. E 8-15: Standard Test methods for tension testing of metallic materials. West Conshohocken, 2015, 23p.

ASTM INTERNATIONAL. E 517-06: Standard Test method for plastic strain ratio $r$ for sheet metal. West Conshohocken, 2006, 8p.

ASTM INTERNATIONAL. E 643-15: Standard Test method for ball punch deformation of metallic sheet material. West Conshohocken, 2015, 4p.

ASTM INTERNATIONAL. E 646-16: Standard Test method for tensile strainhardening exponents (n-Values) of metallic sheet materials. West Conshohocken, 2016, 9p.

ASTM INTERNATIONAL. E 2218-15: Standard Test method for determining forming limit curves. West Conshohocken, 2015, 16p.

ALMEIDA, L.; SCHÖN, C.G. Influencia da deformação na obtenção do coeficiente de anisotropia normal $r$ e do coeficiente de anisotropia planar $\Delta r$

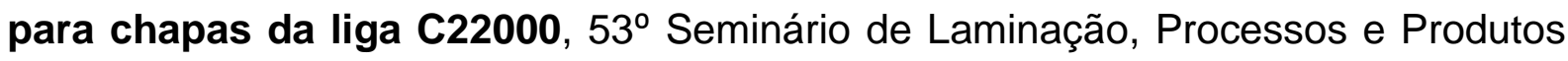
Laminados e Revestidos, ABM Week, Rio de Janeiro, 2016.

AYRES, A.R.; BRAZIER, G.W.; SAJEWSKI, F.V. Evaluating the GMR-Limiting dome height test as a new measure of press formability near plane strain. J. Applied Metal Working, Volume 1, American Society for metal, 1979, $41-49$ p. 
BANABIC, D. Sheet metal forming processes constitutive modeling and numerical simulation, Springer Heidelberg Dordrecht London New York, 2010, 301 p.

BURKE, F.E.; TURNBULL, D. Recrystallization and grain growth. 1952. $220-292$ p.

BRESCIANI, F.E.; SILVA, I.B. da; BATALHA, G.F.; BUTTON, S.T. Conformação plástica dos metais. 6 ed., Campinas, Editora Unicamp, 2011, 254 p.

BJÖRKLUND, O.; NILSSON, L. Failure characteristics of a dual-phase steel sheet, Journal of Materials Processing Technology, 2014. 1190 - 1204 p.

DIETER, G.E. Metalurgia mecânica. 2 ed. Rio de Janeiro: Guanabara dois, 1982. $653 \mathrm{p}$.

DAVIS, J.R. Copper and copper alloys. ASM Specialty handbook, 2001. 652 p.

EMMENS, W.C. Formability - A review of parameters and processes that control, limit or enhance the formability os sheet metal. Springer Heidelberg Dordrecht London New York, 2011. 112 p.

EL-DANAF, E.; KALIDINDI, R.S.; DOHERTY, R.D.; NECKER, C. Deformation texture transition in brass:critical role of micro-scale shear bands. Acta mater, January, 2000. $2665-2673 p$.

FOLLE, L.F.; ARRUDA, R.P.; MARCA, D.; SCHAEFFER, L. Escolha do lubrificante correto torna mais precisa a curva-limite de conformação. Revista: Corte \& Conformação de Metais, Abril, 2008. $64-76$ p.

GHOSH, A.H.; HECKER, S. Failure in thin sheets stretched over rigid punches. Metallurgical Transactions A, vol. 6A, Maio, 1975. 1065 - 1074 p. 
GRACIO, J.J.; FERNANDES, J.V.; ROCHA, A.B da Theoretical prediction of the limit curves for simulation of plastic instability. Elsevier Science Publishers B.V., Amsterdam, 1987. 161 - $170 \mathrm{p}$.

GRAVUS, A.; BANU, M.; RAGNEAU, E.; MAIER, C. An inverse analysis of the Erichsen test applied for the automatic Identification of sheet materials behavior. Scientific Research, Engineering, 2010, 2, 471 - 476 p.

HOWIE, A.; SWANN, P.R. Direct measurements of stacking-fault energies from observations of dislocation nodes. Philosophical Magazine, 1961, 1215-1226 p.

HIJAZI, A.; YARDI, N.; MADHAVAN, V. Determination of forming limit curves using 3D digital image correlation and in-situ observation. Department of Industrial and Manufacturing Engineering Wichita State University, Long Beach, Maio, 2004, $16-20$ p.

HOLMBERG, S.; ENQUIST, B.; THILDERKVIST P. Evaluation of sheet metal formability by tensile tests, Journal of Materials Processing Technology 145, 2004, $72-83 p$.

HOSFORD, W.F.; DUNCAN, J.L. Sheet Metal Forming: A Review, Aluminium Fabrication, November, 1999, $39-44$ p.

HOSFORD, W.F.; CADDELL, R.M. Metal Forming Mechanics and Metallurgy, Third Edition, Cambridge University Press, 2007, 312 p.

ISO INTERNATIONAL STANDARD. 11531-15: Metallic materials - sheet and strip - earing test. 2015, $5 \mathrm{p}$.

ISO INTERNATIONAL STANDARD. 12004-2: Metallic materials - sheet and strip - Determination of forming-limit curves - part 2. 2008, 34 p.

INSTITUT DE RECHERCHES SIDÉRURGIQUES, Influence de différents paramètres sur les courbes limites d'emboutissage, Commission des Communautés Européennes, Communauté Européenne du Charbon et de l'Acier, Convention No 6210-77, 1975, 7 - 33 p. 
KEELER, S. Forming-limit curves becoming more important, Metal Forming Magazine, March, 2015.

KEELER, S. How not use the forming limit curve, Metal Forming Magazine, September, 2015.

KEELER, S. Application and forming of higher strength steel, Journal of Materials Processing Technology 46, 1994, 443 - 454 p.

KALLEND, J.S.; DAVIES, G.J. The development of texture in copper and copperzinc alloys, Gordon and Breach Science Publishers Ltd, Texture, Vol. 1, October, $1971,51-69$ p.

KALUZA, W.; KIM, I.; BLECK, W. Determination of forming limit stress diagrams for the characterization of material for sheet metal forming. Advanced Engineering Materials, Vol. 4, No. 4, 2002. 191 - 195 p.

LEE, D., N.; HAN, H., N. The cube recrystallization-texture related component in the $\beta$-fiber rolling-texture FCC metals. Materials Science Forum, Volume 783-786, 2014, $51-56 \mathrm{p}$.

MOHAMMED, A.A.S.; EL-DANAF, E.A.; RADWAN, AK.A. Equivalent twinning criteria for FCC alloys under uniaxial tension at high temperatures. Materials Science and Engineering A 457, 2006, 373-379 p.

MANDIGO, F.; SHAPIRO, E. A method to develop multistage forming limit curves for copper alloys strip. J. Applied Metalworking, vol. 3, Janeiro, 1984. 157 $164 \mathrm{p}$.

MELANDER, A. A new model of the forming limit diagram applied to experiments on four copper-base alloys, Materials science and engineering, 58, 1983. $63-88 \mathrm{p}$.

PADILHA, A.F. Materiais de engenharia microestrutura e propriedades. Curitiba: Editora Hemus, 2000. 350 p. 
PADILHA, A.F.; SICILIANO JR., F. Encruamento, recristalização, crescimento de grão e textura. 2 ed. São Paulo: Associação Brasileira de Metalurgia e Materiais, 1996. $158 \mathrm{p}$.

PADILHA, A.F.; SICILIANO JR., F. Encruamento, recristalização, crescimento de grão e textura. 3 ed. São Paulo: Associação Brasileira de Metalurgia e Materiais, 2005. $232 \mathrm{p}$.

PLAUT, R.L. Estampabilidade de chapas: ensaios e aplicações. In: Textura e relações de orientação: deformação plástica, recristalização, crescimento de grão. São Paulo: IPEN, 2003. 265 - 308 p.

STÜME, H.P.; FAUSTMANN, J. Introducción a las texturas de los materiales metálicos. Madrid: Editorial Montecorvo, 1969. 286 p.

SCHWINDT, C. D.; STOUT, M.; IURMAN, L.; SIGNORELLI, J. W. Forming limit curve determination of a DP-780 steel sheet. International congress of science and technology of metallurgy and materials, SAM - CONAMET 2013, Procedia Materials Science 8 (2015) $978-985$ p.

SCHÖN, C. G. Mecânica dos Materiais, fundamentos e tecnologia do comportamento mecânico, 1ํe edição, Rio de Janeiro, Elsevier editora Itda, 2013. $552 \mathrm{p}$.

SOUZA, S. A. Ensaios mecânicos de materiais metálicos. Fundamentos teóricos e práticos. São Paulo, Edgard Blücher, 1982. 286 p.

STACHOWICZ, F. Effects of microstructure on the mechanical properties and limit strains in uniaxial and biaxial stretching, Journal of Mechanical Working Technology, 19, 1989, $305-317 \mathrm{p}$.

TAYLOR, B. Forming and forging. ASM handbook. Volume 14, $9^{\circ}$ edição, 1988. $2110 \mathrm{p}$.

THORNTON, P.R.; MITCHELL, T.E.; HIRSCH, P.B. The dependence of cross-slip on stacking-fault energy in face-centred cubic metals and alloys. Philosophical Magazine, 1962, 1349-1369 p. 
TATA STEEL. Predicting forming limit curves - A fast and easy predicition method with improved accuracy. Tata Steel Europe Limited, 2013. 4 p.

TISZA, M.; KOVÁCS, Z. P. New methods for predicting the formability of sheet metals, Production processes and systems, volume 5, No. 1, 2012. $45-54$ p.

TSENG, H.; HUNG, C.; HUANG C. An analysis of the formability of aluminum/copper clad metals with different thicknesses by the finite element method and experiment, Int J Adv Manuf Technol 49, p. 1029 - 1036, 2010.

USIMINAS, Conformação na prensa - fascículo de informações técnica. n 6 . 1999. $58 \mathrm{p}$.

VERMA, A.K.; SHINGWEKER, A.; NIHICHLANI, M.; SINGH, V.; MUKHOPADHAY, $P$. Deformation characterization of cartridge brass. Indian Journal of Engineering \& Materials Science, Vol. 20, August, 2013. $283-288$ p.

WAGONER, R.H. Measurement and analysis of plane-strain work hardening. Metallurgical transactions, Volume 11A, January, 1980. $165-175 \mathrm{p}$.

WAGONER, R.H. Comparison of plane-strain and tensile work hardening in two sheet alloys. Metallurgical transactions, Volume 12A, May, 1981. $877-882 \mathrm{p}$.

WAGONER, R.H.; NARASIMHAN, K. Finite element modeling simulation of inplane forming limit diagrams of sheets containing finite defects. Metallurgical transactions, Volume 22A, November, 1991. $2655-2665$ p.

WIERZBANOWSKI, K.; WRONSKI, M.; LEFFERS, T. Fcc rolling textures reviewed in the light of quantitative comparisons between simulated and experimental textures. Critical reviews in solid state and material sciences, June, 2014. 391 - 422 p.

XAVIER, M.D.; PLAUT, R.L. Ensaios de tração uniaxiais quase planares aplicados na determinação do parâmetro de estampabilidade CLC $_{0} .49^{\circ}$ Seminário de Laminação - Processos e produtos laminados e revestidos, ABM, Outubro, 2012. $417-427$ p. 
XAVIER, M.D.; PLAUT, R.L.; SCHÖN, C.G. Uniaxial near plane strain tensile tests applied to the determination of the $\mathrm{FLC}_{0}$ formability parameter. Materials Research, 2014. $982-986 \mathrm{p}$.

XAVIER, M.D.; SOUSA, E. de; LOPES, A.S; PLAUT, R.L. Técnicas de gravação de rede de círculos em amostras metálicas visando estudos de estampabilidade. $43^{\circ}$ Seminário de Laminação, ABM - Associação Brasileira de Metalurgia e Materiais, 2006. 15 p.

XAVIER, M.D. Análise da estampabilidade de chapas de aço baixo e médio carbono através de deformações plásticas uniaxiais e ortogonais quase planares. Teses (Doutorado) - Escola Politécnica da Universidade de São Paulo, São Paulo, 2014.

XU, Z.T.; PENG, L.F.; LAI, X.M.; FU, M.W. Geometry and grain size effects on the forming limit of sheet metals in micro-scaled plastic deformation. Materials Science \& Engineering A, 2014. $345-353 p$.

XIAO, Z.; YANG, X.; WANG, J.; FANG, Z.; GUO, C.; ZHANG, D.; YANG, Y.; ZHANG, $X$. Influence of $\mathrm{Fe}$ addition on annealing behaviors of a phosphorus containing brass. Journal of alloys and compounds, 2017. 


\section{APÊNDICE A}

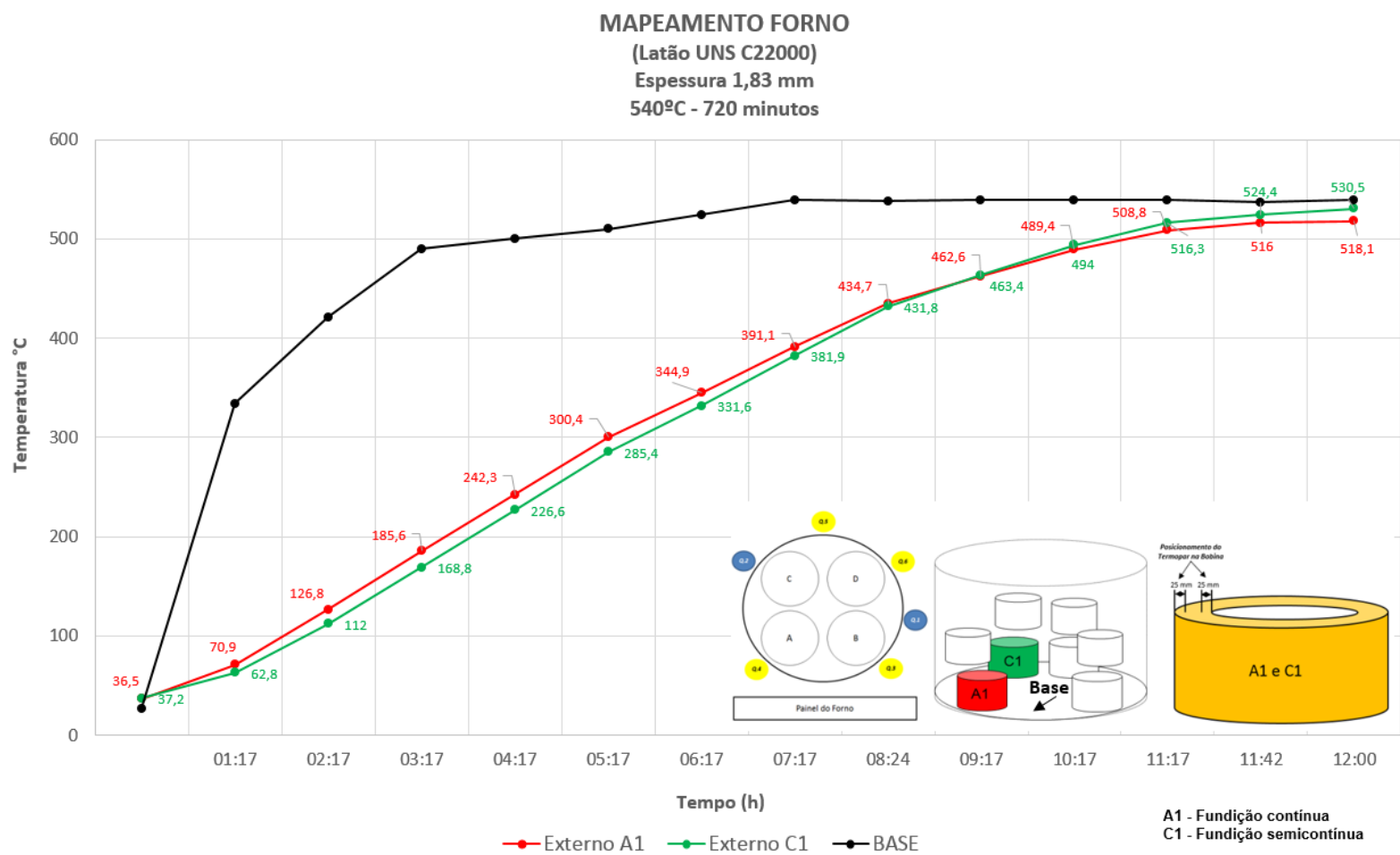




\section{APÊNDICE B}

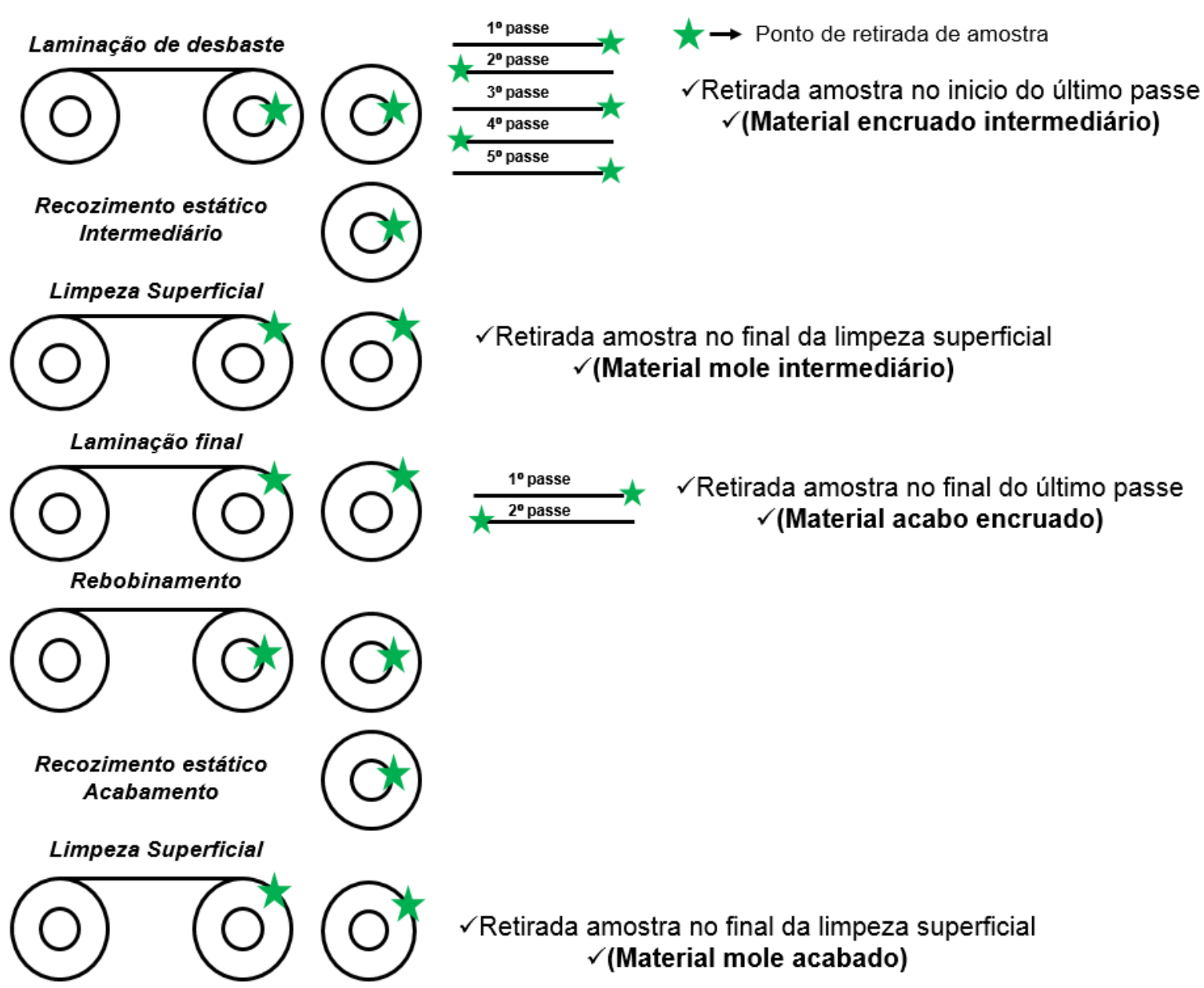




\section{APÊNDICE C}

Tabela 16 Resultados médios das propriedades físicas, processo fundição contínua (encruado), espessura $1,83 \mathrm{~mm}$.

\begin{tabular}{cccc}
\hline Característica & Ângulo $\left(0^{\circ}\right)$ & Ângulo $\left(45^{\circ}\right)$ & Ângulo $\left(90^{\circ}\right)$ \\
& & & \\
\hline \hline Limite de Resistência a Tração (MPa) & 484 & 512 & 551 \\
(Desvio Padrão) & $(7)$ & $(5)$ & $(4)$ \\
\hline Limite de Escoamento (0,2\%) (MPa) & 468 & 486 & 509 \\
(Desvio Padrão) & $(5)$ & $(8)$ & $(8)$ \\
\hline Alongamento (2") (\%) & 6,02 & 3,1 & 4,68 \\
(Desvio Padrão) & $(0,58)$ & $(0,91)$ & $(0,52)$ \\
\hline
\end{tabular}

Tabela 17 Resultados médios das propriedades físicas, processo fundição semicontínua (encruado), espessura 1,83 mm.

\begin{tabular}{cccc} 
Característica & Ângulo $\left(0^{\circ}\right)$ & Ângulo $\left(45^{\circ}\right)$ & Ângulo $\left(90^{\circ}\right)$ \\
\hline \hline Limite de Resistência a Tração (MPa) & & & \\
(Desvio Padrão) & 538 & 566 & 606 \\
$(3)$ & $(4)$ & $52)$ \\
\hline Limite de Escoamento (0,2\%) (MPa) & 520 & 529 & 562 \\
(Desvio Padrão) & $(4)$ & $(3)$ & $(11)$ \\
Alongamento (2)) (\%) & 6,44 & 5,32 & 5,76 \\
(Desvio Padrão) & $(0,64)$ & $(0,78)$ & $(0,27)$ \\
\hline
\end{tabular}




\section{APÊNDICE D}

Tabela 18 Resultados médios das propriedades físicas, processo fundição contínua (mole), espessura $1,83 \mathrm{~mm}$.

\begin{tabular}{cccc}
\hline Característica & Ângulo $\left(0^{\circ}\right)$ & Ângulo $\left(45^{\circ}\right)$ & Ângulo $\left(90^{\circ}\right)$ \\
\hline \hline Limite de Resistência a Tração (MPa) & 269 & 267 & 268 \\
(Desvio Padrão) & $(2)$ & $(3)$ & $(2)$ \\
\hline Limite de Escoamento (0,2\%) (MPa) & 125 & 120 & 119 \\
(Desvio Padrão) & $(5)$ & $(8)$ & $(8)$ \\
\hline Alongamento (2") (\%) & 46,08 & 42,60 & 35,44 \\
(Desvio Padrão) & $(1,59)$ & $(1,75)$ & $(2,17)$ \\
\hline
\end{tabular}

Tabela 19 Resultados médios das propriedades físicas, processo fundição semicontínua (mole), espessura 1,83 mm.

\begin{tabular}{cccc}
\hline Característica & Ângulo $\left(0^{\circ}\right)$ & Ângulo $\left(45^{\circ}\right)$ & Ângulo $\left(90^{\circ}\right)$ \\
\hline \hline Limite de Resistência a Tração (MPa) & 281 & 256 & 255 \\
(Desvio Padrão) & $(1)$ & $(5)$ & $(1)$ \\
\hline Limite de Escoamento (0,2\%) (MPa) & 105 & 102 & 101 \\
(Desvio Padrão) & $(10)$ & $(11)$ & $(3)$ \\
\hline Alongamento (2)) (\%) & 41,34 & 45,00 & 44,92 \\
(Desvio Padrão) & $(0,12)$ & $(0,91)$ & $(0,91)$ \\
\hline
\end{tabular}




\section{APÊNDICE E}

Tabela 20 Resultados dos coeficientes de encruamento $(n)$ e resistência $(K)$ do material mole espessura $1,83 \mathrm{~mm}$ no ângulo $0^{\circ}$.

\begin{tabular}{|c|c|c|}
\hline \multirow[t]{2}{*}{ Características } & \multicolumn{2}{|c|}{ Processos de Fabricação } \\
\hline & Fundição continua & Fundição semicontínua \\
\hline Coeficiente de encruamento (n) & 0,517 & 0,523 \\
\hline (Desvio Padrão) & $(0,020)$ & $(0,067)$ \\
\hline Coeficiente de resistência (K (MPa)) & 525 & 600 \\
\hline (Desvio Padrão) & (9) & (25) \\
\hline
\end{tabular}

Tabela 21 Resultados dos coeficientes de encruamento (n) e resistência (K) do material mole espessura $1,83 \mathrm{~mm}$ no ângulo $45^{\circ}$.

\begin{tabular}{ccc}
\hline Características & \multicolumn{2}{c}{ Processos de Fabricação } \\
\cline { 2 - 3 } & Fundição continua & Fundição semicontínua \\
\hline Coeficiente de encruamento $(\mathrm{n})$ & 0,451 & 0,416 \\
(Desvio Padrão) & $(0,010)$ & $(0,014)$ \\
\hline Coeficiente de resistência (K (MPa)) & 571 & 517 \\
(Desvio Padrão) & $(10)$ & $(9)$ \\
\hline
\end{tabular}

Tabela 22 Resultados dos coeficientes de encruamento $(n)$ e resistência $(K)$ do material mole espessura $1,83 \mathrm{~mm}$ no ângulo $90^{\circ}$.

\begin{tabular}{ccc}
\hline Características & \multicolumn{2}{c}{ Processos de Fabricação } \\
\cline { 2 - 3 } & Fundição continua & Fundição semicontínua \\
\hline Coeficiente de encruamento (n) & 0,474 & 0,544 \\
(Desvio Padrão) & $(0,040)$ & $(0,030)$ \\
\hline Coeficiente de resistência (K (MPa)) & 580 & 582 \\
(Desvio Padrão) & $(20)$ & $(19)$ \\
\hline
\end{tabular}




\section{APÊNDICE F}

Tabela 23 Resultados médios das propriedades físicas, processo fundição contínua (encruado - espessura $1,10 \mathrm{~mm}$ ).

\begin{tabular}{cccc}
\hline Característica & Ângulo $\left(0^{\circ}\right)$ & Ângulo $\left(45^{\circ}\right)$ & Ângulo $\left(90^{\circ}\right)$ \\
& & & \\
\hline \hline Limite de Resistência a Tração (MPa) & 464 & 451 & 471 \\
(Desvio Padrão) & $(5)$ & $(3)$ & $(1)$ \\
\hline Limite de Escoamento (0,2\%) (MPa) & 456 & 425 & 440 \\
(Desvio Padrão) & $(4)$ & $(12)$ & $(3)$ \\
\hline Alongamento (2") (\%) & 3,70 & 3,56 & 3,72 \\
(Desvio Padrão) & $(0,35)$ & $(0,52)$ & $(0,59)$ \\
\hline
\end{tabular}

Tabela 24 Resultados médios das propriedades físicas, processo fundição semicontínua (encruado - espessura 1,10 mm).

\begin{tabular}{|c|c|c|c|}
\hline Característica & Ângulo $\left(0^{\circ}\right)$ & Ângulo $\left(45^{\circ}\right)$ & Ângulo $\left(90^{\circ}\right)$ \\
\hline $\begin{array}{l}\text { Limite de Resistência a Tração (MPa) } \\
\text { (Desvio Padrão) }\end{array}$ & $\begin{array}{l}451 \\
(1)\end{array}$ & $\begin{array}{l}442 \\
(2)\end{array}$ & $\begin{array}{c}462 \\
(2)\end{array}$ \\
\hline $\begin{array}{l}\text { Limite de Escoamento }(0,2 \%)(\mathrm{MPa}) \\
\text { (Desvio Padrão) }\end{array}$ & $\begin{array}{l}443 \\
(3)\end{array}$ & $\begin{array}{l}418 \\
(4)\end{array}$ & $\begin{array}{l}431 \\
(5)\end{array}$ \\
\hline $\begin{array}{l}\text { Alongamento (2") (\%) } \\
\text { (Desvio Padrão) }\end{array}$ & $\begin{array}{c}4,16 \\
(0,09)\end{array}$ & $\begin{array}{c}4,50 \\
(0,52)\end{array}$ & $\begin{array}{c}3,92 \\
(0,26)\end{array}$ \\
\hline
\end{tabular}




\section{APÊNDICE G}

Tabela 25 Resultados médios das propriedades físicas, processo fundição contínua (mole espessura $1,10 \mathrm{~mm}$ ).

\begin{tabular}{cccc}
\hline Característica & Ângulo $\left(0^{\circ}\right)$ & Ângulo $\left(45^{\circ}\right)$ & Ângulo $\left(90^{\circ}\right)$ \\
\hline \hline Limite de Resistência a Tração (MPa) & 282 & 279 & 281 \\
(Desvio Padrão) & $(1)$ & $(2)$ & $(2)$ \\
\hline Limite de Escoamento $(0,2 \%)(\mathrm{MPa})$ & 120 & 116 & 120 \\
(Desvio Padrão) & $(4)$ & $(3)$ & $(1)$ \\
\hline Alongamento (2") (\%) & 40,12 & 42,22 & 39,40 \\
(Desvio Padrão) & $(0,68)$ & $(2,33)$ & $(1,35)$ \\
\hline
\end{tabular}

Tabela 26 Resultados médios das propriedades físicas, processo fundição semicontínua (mole - espessura $1,10 \mathrm{~mm}$ ).

\begin{tabular}{cccc}
\hline Característica & Ângulo $\left(0^{\circ}\right)$ & Ângulo $\left(45^{\circ}\right)$ & Ângulo $\left(90^{\circ}\right)$ \\
\hline \hline Limite de Resistência a Tração (MPa) & 272 & 273 & 270 \\
(Desvio Padrão) & $(1)$ & $(0)$ & $(1)$ \\
\hline Limite de Escoamento (0,2\%) (MPa) & 105 & 109 & 113 \\
(Desvio Padrão) & $(1)$ & $(5)$ & $(5)$ \\
\hline Alongamento (2") (\%) & 42,38 & 43,10 & 41,14 \\
(Desvio Padrão) & $(1,36)$ & $(0,80)$ & $(1,07)$ \\
\hline
\end{tabular}




\section{APÊNDICE H}

Tabela 27 Resultados médios dos coeficientes de encruamento $(n)$ e resistência $(K)$ do material mole espessura acabada no ângulo $0^{\circ}$.

\begin{tabular}{ccc}
\hline Características & \multicolumn{2}{c}{ Processos de Fabricação } \\
\cline { 2 - 3 } & Fundição continua & Fundição semicontínua \\
\hline Coeficiente de encruamento (n) & 0,439 & 0,431 \\
(Desvio Padrão) & $(0,011)$ & $(0,029)$ \\
\hline Coeficiente de resistência (K (MPa)) & 590 & 558 \\
(Desvio Padrão) & $(7)$ & $(18)$ \\
\hline
\end{tabular}

Tabela 28 Resultados médios dos coeficientes de encruamento $(n)$ e resistência $(K)$ do material mole espessura acabada no ângulo $45^{\circ}$.

\begin{tabular}{|c|c|c|}
\hline \multirow[t]{2}{*}{ Características } & \multicolumn{2}{|c|}{ Processos de Fabricação } \\
\hline & Fundição continua & Fundição semicontínua \\
\hline Coeficiente de encruamento (n) & 0,433 & 0,440 \\
\hline (Desvio Padrão) & $(0,018)$ & $(0,029)$ \\
\hline Coeficiente de resistência $(\mathrm{K}(\mathrm{MPa}))$ & 577 & 565 \\
\hline (Desvio Padrão) & (11) & $(14)$ \\
\hline
\end{tabular}

Tabela 29 Resultados médios dos coeficientes de encruamento $(n)$ e resistência $(K)$ do material mole espessura acabada no ângulo $90^{\circ}$.

\begin{tabular}{ccc}
\hline Características & \multicolumn{2}{c}{ Processos de Fabricação } \\
\cline { 2 - 3 } & Fundição continua & Fundição semicontínua \\
\hline Coeficiente de encruamento (n) & 0,413 & 0,424 \\
(Desvio Padrão) & $(0,012)$ & $(0,018)$ \\
\hline Coeficiente de resistência (K (MPa)) & 570 & 553 \\
(Desvio Padrão) & $(9)$ & $(11)$ \\
\hline
\end{tabular}

